\title{
First checklist of lichens and lichenicolous fungi from Mauritius, with phylogenetic analyses and descriptions of new taxa
}

\author{
Paul Diederich ${ }^{1 *}$ \& Damien Ertz ${ }^{2,3}$
}

\section{Article info}

Received: 29 Sept. 2019

Revision received: 11 Mar. 2020

Accepted: 16 Mar. 2020

Published: 2 Jun. 2020

Associate Editor

Nicolas Magain

\begin{abstract}
A first checklist of the lichens and lichenicolous fungi from the Republic of Mauritius is presented. It is based on older literature reports and on collections made by the authors, mainly in 2016, from the isles of Mauritius and Rodrigues. A total of 216 species are accepted, either as relevant specimens have recently been critically studied or revised by lichen taxonomists, or as we have collected and identified such material ourselves. A further 226 taxa have been reported from Mauritius but are not accepted here, either as no relevant herbarium material has recently been examined, or as previous records are dubious or erroneous; 111 taxa have been newly described from Mauritius in the past, plus 12 of which the Mauritian origin is dubious. Here we report 56 taxa as new for the island of Mauritius, and we describe two new genera (Baidera, Serusiauxia) and eight new species (Baidera mauritiana, Biatoropsis millanesiana, Chapsa alletii, Collemopsidium mauritiae, Nyungwea pyneei, Porina florensii, Pyrenula muriciliata, Serusiauxia inexpectata). Two new combinations are proposed: Loekoesia apostatica (三 Lecanora apostatica) and Sticta flavireagens (三 Stictina flavireagens). Phylogenetic analyses are presented for species of Arthoniales, Biatoropsis, Porinaceae, Pyrenulaceae and Teloschistales.
\end{abstract}

Key words: Arthoniales, Biatoropsis, Indian Ocean, Porinaceae, Pyrenulaceae, Rodrigues,

Teloschistales

\section{Introduction}

The Republic of Mauritius lies in the southwestern Indian Ocean about $900 \mathrm{~km}$ east of Madagascar and about $2000 \mathrm{~km}$ off the southeast coast of the African continent. It consists of two main volcanic islands belonging to the Mascarene Archipelago: Mauritius, with a land area of $1865 \mathrm{~km}^{2}$ (highest point Piton de la Petite Rivière Noire, $828 \mathrm{~m})$; and Rodrigues, which is the smallest $\left(109 \mathrm{~km}^{2}\right.$; highest point Mt Limon, $398 \mathrm{~m}$ ) and most isolated of the Mascarene Islands, being located about $574 \mathrm{~km}$ east of Mauritius. Basaltic lava is the main type of rock on both islands, but Rodrigues also has areas of limestone made of consolidated coral sands. Mauritius and Rodrigues are the two oldest main islands of the Mascarenes, having been available for colonization by diverse biota for 8-15 million years (Thébaud et al. 2009). The coastal areas of both islands have a dry tropical climate contrasting

\footnotetext{
${ }^{1}$ Musée national d'histoire naturelle, 25 rue Munster, L-2160 Luxembourg, Luxembourg

${ }^{2}$ Meise Botanic Garden, Department of Research, Nieuwelaan 38, B-1860 Meise, Belgium

${ }^{3}$ Fédération Wallonie-Bruxelles, Service général de l'Enseignement non obligatoire et de la Recherche scientifique, rue A. Lavallée 1, B-1080 Bruxelles, Belgium

* Corresponding author e-mail: paul.diederich@education.lu
}

with the more humid upper elevation, which receives the highest amount of rainfall. Fog is abundant at the upper altitudes and provides the optimum climate for the development of rich macrolichen communities (Figs 1-2).

The Mascarene Islands harbour a very rich and diverse angiosperm flora, with an estimated $\sim 960$ native species, about $75 \%$ of them considered to be endemic to the archipelago (Thébaud et al. 2009). The level of island endemism is also high, being $39.5 \%$ in Mauritius (273 single island endemics of the 691 native species) and $31.1 \%$ in Rodrigues (47 single-island endemics of the 150 native species) (Baider et al. 2010). The archipelago is even part of the world's most important biodiversity hotspots (Myers et al. 2000). The pristine fauna and flora of the Mascarenes have been decimated since humans arrived in 1598. The dodo (Raphus cucullatus), a flightless bird belonging to the Columbidae and endemic to Mauritius, is the emblematic representative of them (Cheke \& Hume 2008). Although native vegetation remains, all the pristine forest covering Rodrigues has been destroyed, while barely $2 \%$ of the original forest cover has been left in Mauritius, mainly lowland rainforests and dense cloud forests at the highest elevation. They are concentrated in Black River Gorges National Park in the southwest, 
the Bambou Mountain Range in the southeast, and the Moka-Port Louis Ranges in the northwest, with some isolated mountains such as Corps de Garde, Le Morne Brabant, and several offshore islets. These forest remnants are often invaded by alien animals (e.g., deer, mongooses, monkeys, pigs, rats) and plant species (e.g., Psidium cattleianum, Ardisia crenata, Ligustrum robustum, Rubus alceifolius, Wikstroemia indica) (Thébaud et al. 2009, Virah-Sawmy et al. 2009), which have a strong negative impact on biodiversity. Considerable efforts are deployed for conservation management work to fight alien species and restore original forests.

The lichen flora of Mauritius and Rodrigues is poorly known and has never been thoroughly revised. This paper aims to provide a first checklist for the lichens and lichenicolous fungi of Mauritius and Rodrigues, along with new records and descriptions of new species resulting from our recent collecting trips.

\section{Material and methods}

Preparation of the checklist and morphological examination

The checklist includes both data found in the literature and new results based on our collections. The entire literature for Mauritius has been checked, and all previously published reports of Mauritian lichens have been included in the checklist. Species printed in bold are accepted; these usually represent species either recently studied and published by taxonomists or examined by us. Other species are considered dubious, especially those from the older literature, as no specimens exist or as they have never been critically revised. We have not examined most historical specimens, except for those indicated by an exclamation mark (!). Specimens we collected, mainly in 2016, are retained in MAU (Mauritius Herbarium), while duplicates are kept in BR (Damien Ertz) and in the private herbarium of P. Diederich. A few additional specimens from BM and MAU have been studied.

Hand-made sections of ascomata and thalli were studied in water, $5 \% \mathrm{KOH}(\mathrm{K})$, Lugol's reagent $\left(1 \% \mathrm{I}_{2}\right)$ without (I) or with $\mathrm{KOH}$ pre-treatment $(\mathrm{K} / \mathrm{I})$, lactophenol-cotton blue (LCB), Congo Red or phloxine B. Macroscopic photographs were made using a Canon 40D camera with a Canon MP-E $65 \mathrm{~mm}$ lens or a Nikon BD Plan 10× microscope objective, StackShot (Cognisys) and Helicon Focus (HeliconSoft) for increasing the depth of field; or with a Keyence VHX-5000 digital microscope and a VH-Z20R/W/T lens (Baidera, Nyungwea, Serusiauxia). Microscopic photographs were prepared using a Leica DMLB microscope with interference contrast, fitted with a Leica EC3 camera; or an Olympus BX51 microscope with interference contrast, connected to an Olympus Color View I digital camera (Baidera, Nyungwea, Serusiauxia). Chemical spot reactions are abbreviated as $\mathrm{K}(5 \% \mathrm{KOH})$, $\mathrm{C}$ (commercial bleach), $\mathrm{KC}$ ( $\mathrm{K}$ followed by $\mathrm{C}$ ) and $\mathrm{PD}$ (paraphenylenediamine), while UV refers to fluorescence at $366 \mathrm{~nm}$. Thin-layer chromatography followed Elix (2014). Ascospores measurements of Baidera mauritiana,
Porina florensii and Pyrenula muriciliata are given as (min.-)average minus standard deviation-average plus standard deviation(-max.).

\section{Molecular techniques}

Well-preserved and freshly collected specimens were used for sequencing. A group of 4 to 6 soredia (Serusiauxia) or tiny fragments of the hymenium or thallus (Baidera mauritiana, Granulopyrenis sp., Loekoesia apostatica, Nyungwea pyneei, Porina florensii, Pyrenula quassiicola, Squamulea cf. squamosa) were used for direct PCR as described in Ertz et al. (2015). For Biatoropsis millanesiana, total DNA was extracted directly from the specimens examined (Table 1) using the Qiagen DNeasy Plant MiniKit according to the manufacturer's instructions, but using $50 \mu \mathrm{l}$ of water in each of the last two steps of final elution.

A targeted fragment of $\sim 0.8 \mathrm{~kb}$ of the mitochondrial ribosomal RNA small subunit (mtSSU) was amplified for Granulopyrenis, Loekoesia, Porina, Pyrenula and Squamulea using primers mrSSU1 and mrSSU3R (Zoller et al. 1999 ), and a fragment of $\sim 1 \mathrm{~kb}$ of the RPB2 protein-coding gene was amplified for Baidera and Nyungwea using primers $f R P B 2-7 \mathrm{cF}$ and $f R P B 2-11 \mathrm{aR}$ (Liu et al. 1999). Amplification reactions were prepared for a $50 \mu \mathrm{l}$ final volume containing the lichen material as explained in Ertz et al. (2018b). The yield of the PCRs was verified by running the products on a $1 \%$ agarose gel using ethidium bromide. Both strands were sequenced by Macrogen $\AA$ using amplification primers. Sequence fragments were assembled with Sequencher v. 5.3 (Gene Codes Corporation, Ann Arbor, Michigan). For Biatoropsis millanesiana, we amplified nuc rDNA internal transcribed spacer 1 (ITS1), 5.8S, internal transcribed spacer 2 (ITS2) and a fragment of $\sim 1000$ bp in the rDNA 28S region with primers ITS1F (Gardes \& Bruns 1993), BasidLSU3-3 (Millanes et al. 2011), BasidLSU1-3 (Millanes et al. 2011), BasidLSU1-5 (Millanes et al. 2011), BasidLSU13-5 (Millanes et al. 2011) and LR5 (Vilgalys \& Hester 1990). PCR amplifications were performed using Illustra ${ }^{\mathrm{TM}}$ Hot Start PCR beads according to the manufacturer's instructions, with the primer combinations and settings described in Millanes et al. (2011). Sequencing followed Millanes et al. (2016).

\section{Taxon selection and phylogenetic analyses}

Ten new mtSSU sequences were obtained for this study: one for Granulopyrenis (MN989203 for Ertz 21425), one for Loekoesia apostatica (MN989204 for Diederich 18518), two for Porina florensii (MN989205 for Diederich 18348, MN989206 for Diederich 18453), one for Pyrenula quassiicola (MN989207 for Ertz 21460), four for Serusiauxia inexpectata (MN989208 for Diederich 17815, MN989209 for Diederich 18239, MN989210 for Ertz 21490, MN989211 for Ertz 21496) and one for Squamulea cf. squamosa (MN989212 for Diederich 18394). Three new RPB2 sequences were obtained for the Arthoniales: two for Baidera mauritiana (MN989868 for Ertz 21443-hymenium, MN989869 for Ertz 21443-thallus) and one for Nyungwea pyneei (MN989870 for Ertz 21450). 

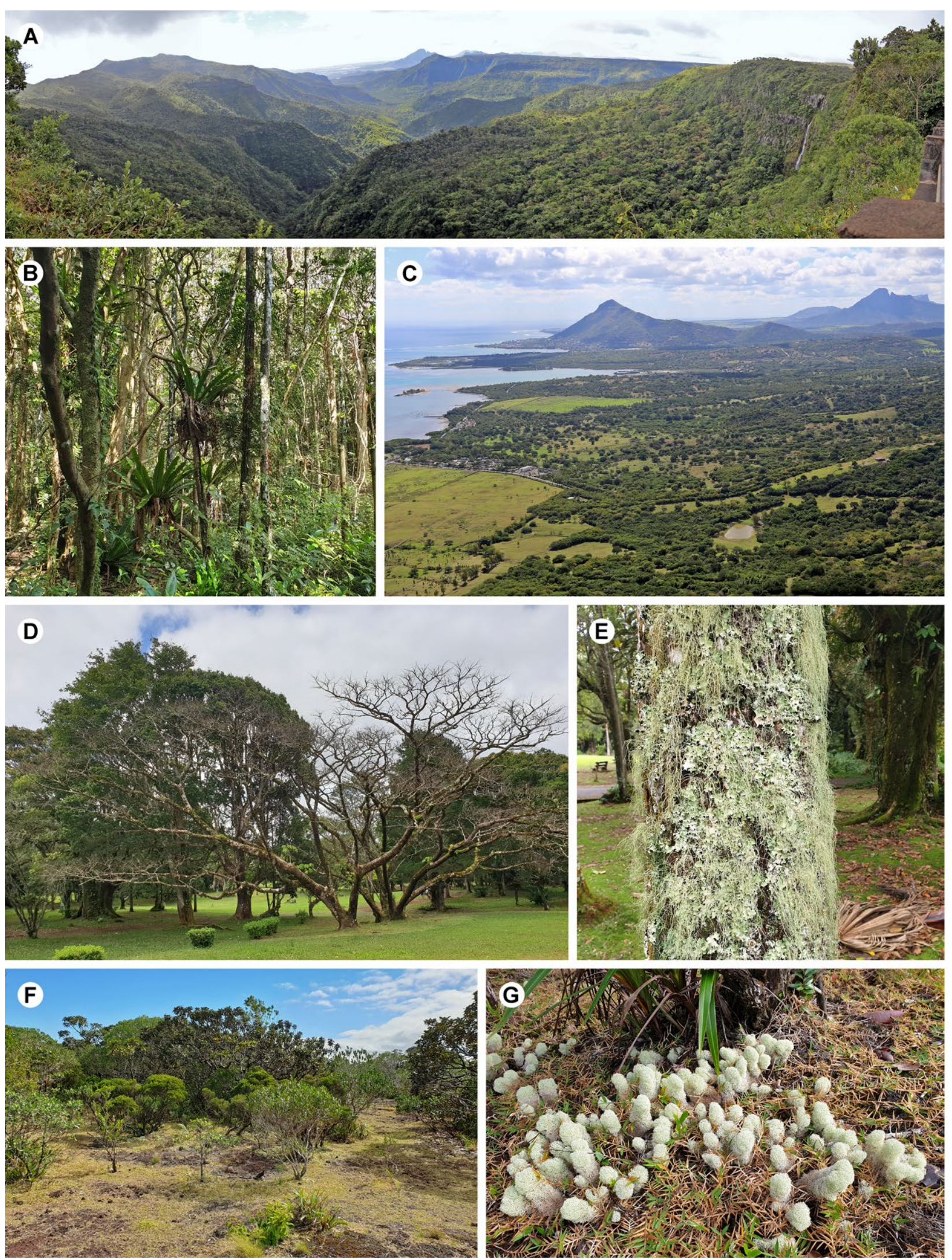

Figure 1. Mauritian landscapes and lichen habitats. A - Black River Gorges Natural Park with natural forest; B - dense natural forest in Brise Fer with the endemic Mauritian ebony tree, Diospyros tesselaria; C - typical coastal landscape of Mauritius; D - Curepipe Botanic Gardens, an extraordinary habitat for corticolous lichens; E - palm tree in Curepipe Botanic Gardens, covered by Usnea and Parmotrema species; F - Pétrin heathland, with a rich terricolous and corticolous lichen flora; $\mathrm{G}$ - Cladonia confusa in Pétrin heathland. Photos: P. Diederich. 


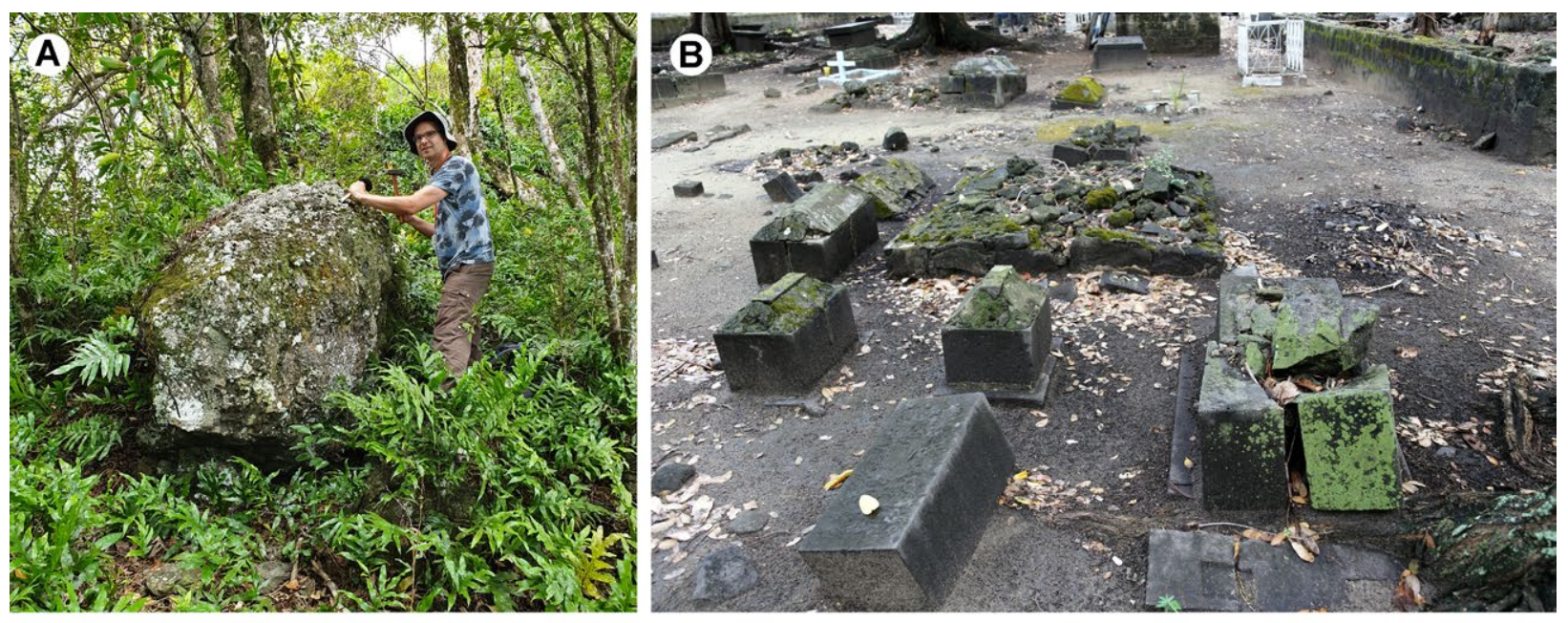

C
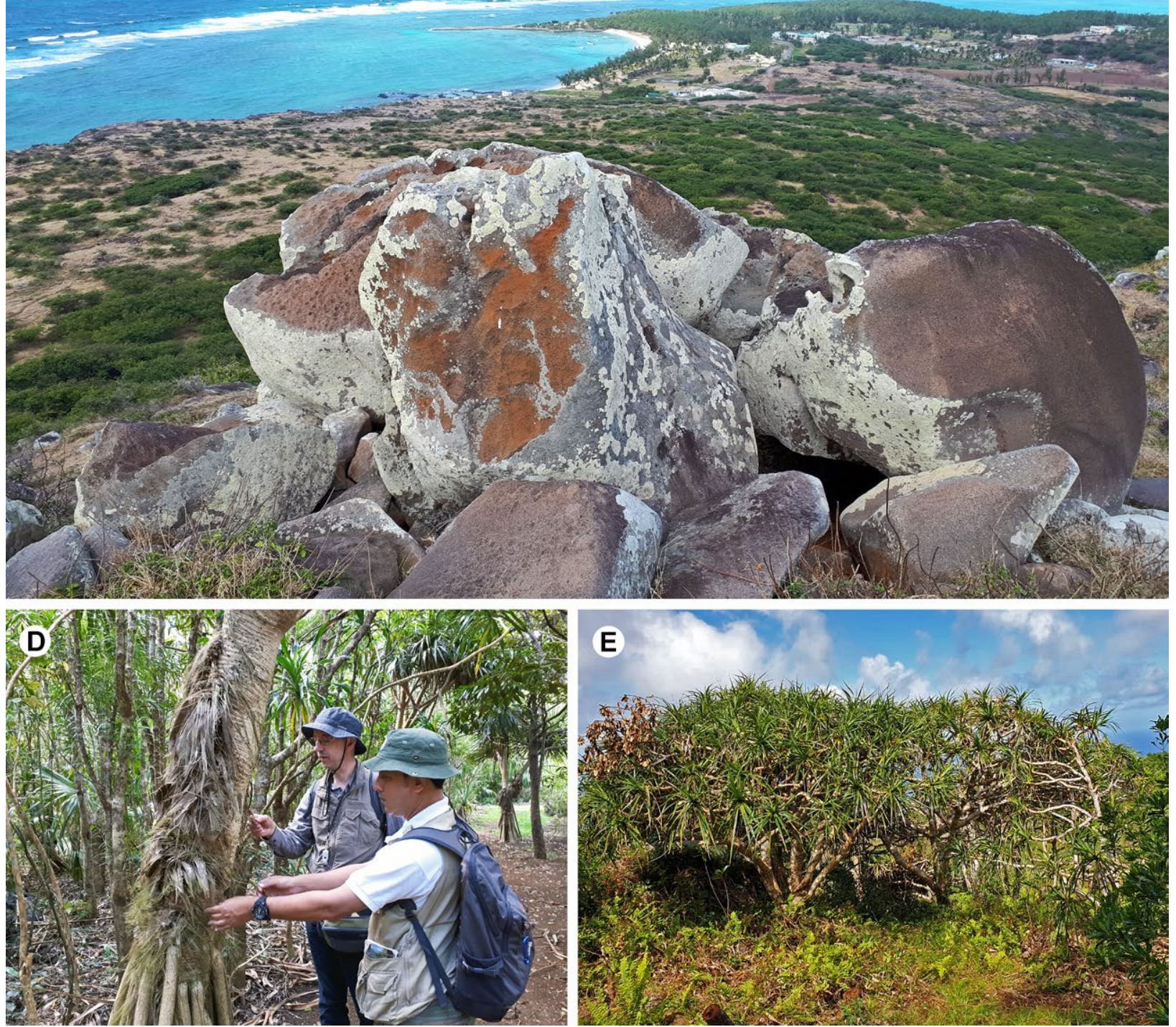

Figure 2. Mauritian landscapes and lichen habitats (continued). A - rocky boulder in Ebony Forest, Chamarel; B - historic cemetery in La Preneuse near Tamarin with a rich flora of Lichinaceae, Collemopsidium mauritiae sp. nov., Endocarpon spp., Squamulea cf. squamosa, etc.; C - typical landscape on the east coast of Rodrigues island, with a rocky outcrop on the top of a hill and sparse lowland vegetation with Pandanus, Acacia and Casuarina; D - Grande Montagne Nature Reserve in Rodrigues; E - Pandanus trees in Rodrigues, with a particularly diverse corticolous lichen vegetation. Photos: P. Diederich (A-B, E), D. Ertz (C-D). 
Table 1. Voucher information and GenBank accession numbers (NCBI) for ITS and nuLSU sequences of Tremellales used in this study. Newly generated sequences are in bold. Type specimens are indicated by (T).

\begin{tabular}{|c|c|c|c|}
\hline Taxon name - DNA extraction number & Specimen data & ITS & nLSU \\
\hline Biatoropsis hafellneri - AM299 & Azores, Diederich 17087b (S F264687) & KJ404880 & KJ437226 \\
\hline Biatoropsis hafellneri - AA10 (T) & UK, Wedin 7308 (UPS F766824 - holotype) & JN053489 & JN043595 \\
\hline Biatoropsis millanesiana sp. nov. - AM784 (T) & Mauritius, Diederich 18524 (MAU - holotype) & MN973671 & MN973663 \\
\hline Biatoropsis millanesiana sp. nov. - AM1171 & Mauritius, Diederich 18921 (MAU - topotype) & MN973669 & MN973661 \\
\hline Biatoropsis millanesiana sp. nov. - AM1026 & Mauritius, Diederich 18291 (MAU) & MN973670 & MN973662 \\
\hline Biatoropsis millanesiana sp. nov. - AM1168 & Rodrigues, Diederich 18979 (MAU) & MN973666 & MN973658 \\
\hline Biatoropsis millanesiana sp. nov. - AM1169 & Rodrigues, Diederich 19029 (MAU) & MN973667 & MN973659 \\
\hline Biatoropsis millanesiana sp. nov. - AM1170 & Rodrigues, Diederich 18997 (MAU) & MN973668 & MN973660 \\
\hline Biatoropsis millanesiana sp. nov. - AM567 & Seychelles, Diederich 18087 (SEY) & KX687750 & MN973656 \\
\hline Biatoropsis minuta - AM172 & Canada, Diederich 17269 (S F102406) & KJ404866 & KJ437211 \\
\hline Biatoropsis minuta - AM229 & India, Divakar s.n. (MAF-Lich) & KJ404868 & KJ437213 \\
\hline Biatoropsis minuta - AM137 (T) & Spain, Aragón s.n. (S F102398 - holotype) & KJ404869 & KJ437214 \\
\hline Biatoropsis minuta - CO294 & Sweden, Wedin 7903 (S F102401) & JN053487 & JN043593 \\
\hline Biatoropsis protousneae - AM215 & Argentina, Wedin 8601 (S F264822) & KJ404861 & KJ437206 \\
\hline Biatoropsis protousneae - AM214 & Argentina, Wedin 8615 (S F264823) & KJ404865 & KJ437210 \\
\hline Biatoropsis protousneae - AM141 & Chile, Pérez-Ortega 216 (MAF-Lich) & KJ404860 & KJ406316 \\
\hline Biatoropsis protousneae - AM142 (T) & Chile, Pérez-Ortega 207 (MAF-Lich - isotype) & KJ404864 & KJ406321 \\
\hline Biatoropsis usnearum - AM196 & Austria, Hafellner 49578 (GZU 02-99) & KJ404878 & KJ437224 \\
\hline Biatoropsis usnearum - AM298 & Azores, Diederich 17087a (S F264684) & KJ404872 & KJ437217 \\
\hline Biatoropsis usnearum - AM202 & Sweden, Westberg 09-676 (S F264681) & KJ404876 & KJ437221 \\
\hline Biatoropsis usnearum - AM171 & UK, Coppins s.n. (S F102407) & KJ404879 & KJ437225 \\
\hline Biatoropsis sp. A1 - AM112 & Canary Islands, Diederich 16700 (S F102402) & KJ404856 & KJ406307 \\
\hline Biatoropsis sp. A1 - AM192 & Chile, Etayo 23158 (MAF-Lich 15645) & KJ404851 & KJ437196 \\
\hline Biatoropsis sp. A1 - AM296 & New Zealand, Wedin 9033 (S F180874) & KJ404854 & KJ437199 \\
\hline Biatoropsis sp. A1 - AM143 & Spain, Pérez-Ortega s.n. (MAF-Lich) & KJ404857 & KJ437202 \\
\hline Biatoropsis sp. E - AM213 & Argentina, Wedin 8742 (S F264824) & KJ404882 & KJ437227 \\
\hline Biatoropsis sp. F - AM576 & France, Diederich 18149 (herb. Diederich) & KX687749 & MN973657 \\
\hline Biatoropsis sp. F - AM10 & New Zealand, Berger 16609 (S F92784) & KJ404884 & KJ437229 \\
\hline Biatoropsis sp. F - AM1040 & New Zealand, Berger 31715 (herb. Berger) & MN973672 & MN973664 \\
\hline Biatoropsis sp. F - AM295 & New Zealand, Wedin 9429 (S F181399) & KJ404883 & KJ406305 \\
\hline Biatoropsis sp. F - AM166 & USA, Kocourková s.n. (S F264679) & KJ404885 & KJ406308 \\
\hline Tremella cetrariicola - AM111 & Finland, Suija s.n. (S F102413) & JN053490 & JN043596 \\
\hline
\end{tabular}

Five new nuITS or 28S rDNA sequences were obtained for Biatoropsis millanesiana (Table 1). Their closest relatives based on 'megablast' searches were retrieved from GenBank. The phylogenetic trees of Ertz et al. (2019) and Gueidan et al. (2016) were used for the placement of the newly sequenced taxa of Porinaceae and Pyrenulaceae respectively. Additional members of the Arthoniales were selected for the placement of Baidera mauritiana and Nyungwea pyneei from Ertz \& Tehler (2011), Ertz et al. (2015) and Frisch et al. (2014), and additional species of Teloschistales were selected for the placement of Loekoesia apostatica and Squamulea cf. squamosa, mainly from Arup et al. (2013). In addition to 24 Biatoropsis specimens representing all known species in the genus and the seven clades studied in Millanes et al. (2014, 2016), seven additional specimens from the Indian Ocean were included in the molecular study (Table 1).

Sequences of Arthoniales, Porinaceae, Pyrenulaceae and Teloschistales were aligned using MAFFT v7.402 (Katoh et al. 2002) on the CIPRES Web Portal (Miller et al. 2010) and improved manually using Mesquite 3.04 (Maddison \& Maddison 2015). Terminal ends of sequences and ambiguously aligned regions were delimited manually and excluded from the datasets. Sequences of Biatoropsis were aligned using the Q-INS-i algorithm (Katoh \& Toh 2008) of the multiple sequence alignment software MAFFT version 7 (Katoh \& Toh 2008; Katoh et al. 2017). Two data matrices were produced: one including ITS and one including 28S rDNA. Ambiguous regions were identified and eliminated with Gblocks version $0.91 \mathrm{~b}$ (Castresana 2000).

Bayesian analyses were carried out on the Arthoniales, Porinaceae, Pyrenulaceae and Teloschistales datasets using the Metropolis-coupled Markov chain Monte Carlo (MCMCMC) method in MrBayes v. 3.2.6 (Huelsenbeck \& Ronquist 2001; Ronquist \& Huelsenbeck 2003) on the CIPRES Web Portal (Miller et al. 2010). Best-fit evolutionary models were estimated using the Akaike information criterion (AIC; Akaike 1973) as implemented in jModelTest2 2.1.6 (Darriba et al. 2012). The GTR $+\mathrm{I}+\mathrm{G}$ model was selected for the 'Porinaceae' dataset, the TIM2+I+G model for the 'Pyrenulaceae' dataset, the $\mathrm{HKY}+\mathrm{I}+\mathrm{G}$ model for the 'Teloschistales' dataset, the $\mathrm{GTR}+\mathrm{I}+\mathrm{G}$ model for both the RPB21st and RPB22nd positions for the 'Arthoniales' dataset, and the TIM $2+\mathrm{I}+\mathrm{G}$ model for the RPB23rd position for the 'Arthoniales' dataset. For each dataset, two parallel MCMCMC runs were performed, each using four independent chains and 
40 million generations, sampling trees every $1000^{\text {th }}$ generation. Tracer v. 1.6 (Rambaut \& Drummond 2007) was used to ensure that stationarity was reached by plotting the log-likelihood values of the sample points against generation time, making sure that the ESS values were higher than 200. Convergence between runs was also verified using the PSRF (potential scale reduction factor), where all values were equal or close to 1.000 . Posterior probabilities (PP) were determined by calculating a majority-rule consensus tree generated from the 60002 post-burn-in trees of the 80002 trees sampled by the two MCMCMC runs using the sumt option of MrBayes for the four datasets. In addition, a maximum likelihood (ML) analysis was performed on the CIPRES Web Portal (Miller et al. 2010) using RAxML-HPC2 v. 8.2.10 (Stamatakis 2014) with 1000 ML bootstrap iterations (ML-BS) and the GTRGAMMA model. The RAxML trees did not contradict the Bayesian trees topology for the strongly supported branches. Therefore, only the RAxML trees are shown, with the bootstrap support values added above or near the internal branches (Figs 4, 10, 13, 16). ML-BS $\geq 70$ and PP $\geq 95$ were considered significant. Internal branches considered strongly supported by both the RAxML and Bayesian analyses are represented by thicker lines (Figs 4, 10, 13, 16). Phylogenetic trees were visualized using FigTree v. 1.4.2 (Rambaut 2012).

For the Biatoropsis datasets, maximum likelihood analyses were performed in RAxMLGUI 1.5 (Silvestro \& Michalak 2012), a graphical front-end for RAxML (Stamatakis 2014), using the GTRGAMMAI model of nucleotide substitution applied to all partitions. We performed a thorough ML search with 10 runs and assessed node support by thorough bootstrapping using 1000 bootstrap pseudoreplicates.

\section{The Lichenological Exploration of Mauritius}

In addition to literature references cited below, the historical data are based partly on valuable information obtained from Wikipedia (de.wikipedia.org, en.wikipedia.org and fr.wikipedia.org).

\section{Mauritius}

The first person to collect lichens in Mauritius seems to have been Philibert Commerson (1727-73), a French physician, naturalist and explorer. During his circumnavigation with Bougainville in 1767-68, he reached Mauritius on 8 November 1768. While Bougainville left Mauritius one month later, Commerson stayed there and enjoyed excellent working conditions at the botanical garden in Pamplemousses. He also explored Madagascar and Reunion, but returned to Mauritius in February 1771, where he died unexpectedly in 1773 . His important collections were later brought back to Paris, but it seems that most have not yet been studied. Bory de Saint-Vincent (1828) published the new Roccella flaccida (a synonym of $R$. boryi), based on a Mauritius specimen obtained in 1826 from A. L. de Jussieu and collected by P. Commerson; Tehler \& Irestedt (2007) lectotypified R. flaccida on specimen Jussieu 2444 (PC).
Louis-Marie Aubert du Petit-Thouars (1758-1831) was a French botanist who visited Mauritius in 1792. He collected many plants and described numerous new orchids from Mauritius, Reunion and Madagascar. In 1801, he guided a botanical excursion with Bory de Saint-Vincent (see below). He returned to France in 1802 , bringing with him a herbarium of 2000 plant specimens. Although he did not intentionally collect lichens, the type specimen of the foliicolous lichen Strigula elegans (a synonym of $S$. smaragdula) kept in $G$ (G 00292267) was collected by him 'in insula Franciae, supra folia arborum'.

Jean Baptiste Bory de Saint-Vincent (1778-1846) was a French naturalist who joined an expedition to Australia organized by Captain Nicolas Baudin in 1800 . However, in March 1801 he left the vessel at Mauritius and spent two years exploring Reunion and other isles in the Indian Ocean. In 1804 he published the results from his expedition in the book 'Voyage dans les quatre principales isles des mers d'Afrique, fait par ordre du Gouvernement, pendant les années neuf et dix de la République (1801 et 1802), avec l'histoire de la traversée du capitaine Baudin jusqu'au Port-Louis de l'Ile Maurice'. When he arrived in Port-Louis, he met French botanist Louis-Marie Aubert du Petit-Thouars (see above), who accompanied him during an excursion. In May 1801, he explored the Plaines Wilhems and especially the Corps de Garde (729 m high) in the Moka Range (a mountain range forming a semicircle around the capital, Port Louis). There he collected cryptogams, especially a beautiful golden undescribed Usnea species that he previously had discovered in Brittany (Bory 1804: 197). Then he visited Le Pouce $(812 \mathrm{~m})$, also in the Moka Range, where he found a remarkable vegetation. In June 1801, he visited the 'jardin d'Etat aux Pamplemousses', then the forests in the southern part of Mauritius, including the 'Piton'. On 11 August 1801, he left Mauritius for Reunion. Although Bory reported many lichen species from Reunion (Bory 1804), including a number of new species, it seems that he did not publish any of his lichen specimens from Mauritius. Several specimens he collected in Mauritius have been located, such as the lectotype of Sticta dichotoma and the lectotype of S. mougeotiana (both kept in PC-Thuret), a specimen later identified by Hue as Stictina carpoloma (PC 0072998), or a specimen collected in 1802 (surely a lapsus for 1801, see above) 'sur les grands arbres' on Le Pouce (PC 0009140). Other specimens from Bory are annotated 'Iles de France et Bourbon', such as the lectotype of Sticta aurigera var. nuda (PC-Thuret), and some of these might originate from Mauritius as well. In his 'Histoire des lichens. Genre Sticta', annotated '1822' but published only in 1825, dedicated 'au Colonel Bory de Saint Vincent', Delise (1825) studied the rich collections made by Bory in the African isles. In his 'Essai sur les cryptogames des écorces exotiques officinales', Fée (1824: CI) cited 'Delise, Monog. ined., cum icon.', following which the new Roccella boryi 'Habitat in insula Borboniae, Mauritii, etc., ad rupes'; Tehler \& Irestedt (2007) eventually lectotypified that name on a specimen from Ile de Bourbon (Reunion); although no collector 
was mentioned, this certainly refers to specimens collected by Bory.

Bohemian botanist Franz Wilhelm Sieber (1789-1844) collected plants in Europe, the Middle East, Southern Africa and Australia. During his 1822-24 circumnavigation, he visited South Africa, Mauritius and Australia. He also sent Bohemian botanist Wenceslas Bojer (17951856) to Mauritius in 1821-22 to collect plants for him. After 1820, Sieber's behaviour and publications became progressively more erratic, and he spent the final fourteen years of his life in the Prague insane asylum, where he died at the age of fifty-five. Annotations on his herbarium labels are unreliable, and it seems that at least part of his lichen specimens annotated Mauritius originate from other countries (see below under Cora gyrolophia and Sticta flavireagens). Laurer's (1827) 'Sieber'sche Lichenen' reports on collections obtained from Sieber after his circumnavigation. About 25 specimens collected by W. Bojer in Mauritius, two of them dated 1836 and 1838, are now kept in MAU.

French botanist Charles-Paulus Bélanger (1805-81) travelled to the 'Indes Orientales' (Southeast Asia) and incompletely published the results in his work 'Voyages aux Indes orientales par le nord de l'Europe, les provinces du Caucase, la Géorgie, l'Arménie et la Perse, suivi de détails topographiques et autres sur le Pégou, les îles de Java, de Maurice et de Bourbon, sur le Cap de Bonne-Espérance et Sainte-Hélène, pendant les années 1825, 1826, 1827,1828 et $1829^{\prime}$. Most lichen specimens collected in Mauritius and published by Bélanger (1834) are kept in $\mathrm{PC}$ in the Montagne herbarium. A duplicate of the type of Oxystoma friesianum, collected in Pamplemousses, is also kept in $\mathrm{G}$.

British physician and botanist Philip Burnard Ayres (1813-63) was appointed to Mauritius in 1856, where he assembled extensive plant collections. He did not publish on lichens, but collected at least 25, amongst them the type specimens of Cladonia intermediella, Ocellularia mauritiana, Opegrapha angulosa, Pannaria macrocarpa, Pyrenula truncata and Toninia ayresiana. Most specimens are kept in BM, E, G or K. Many originate from Le Pouce, and some are annotated ' 1857 '.

Mauritian naturalist (Jean Marie Rose) Albert Daruty de Grandpré (1853-1928) collected over 150 lichen specimens in 1873-74, almost all kept in MAU. Daruty (1873) published over 80 species, unfortunately without any indications of locality or ecology, all identified by H. A. Weddell; eight new species, published without descriptions and without type citations, are nomina nuda. Two specimens are also kept in PC (Stictina argyracea, PC0072291; S. rigidula, PC0072292).

Mauritian physician and naturalist Victor de Robillard (1856-84) collected about 50 lichen specimens in Mauritius, mainly in 1876, including the types of Pertusaria pertusa var. minor, $P$. pertusella, $P$. subtruncata, Stictina robillardii, Synechoblastus robillardii and Usnea straminea.

In a small report on the flora of Round Island (Johnston 1894), Henry Halcro Johnston (1856-1939) collected lichens that were later identified by $\mathrm{C}$. H. Wright from the
Kew herbarium; he also collected the type of Endocarpon johnstonii on Ile aux Fouquets.

The Mauritius Herbarium (MAU) currently houses about 860 Mauritian lichen specimens from many collectors (Baider, pers. comm.), the most important ones, in addition to A. Daruty, being British botanist Reginald Edward Vaughan (1895-1987) (almost 200 specimens collected in 1928-81), American botanist David H. Lorence (131 specimens collected in 1971-76 and 1994) and British botanist Colville Barclay (1913-2010) (69 specimens collected in 1971-78).

Jonathan D. Sauer (1918-2008) collected about 20 lichens in the Macchabee Forest and Pétrin between 1959 and 1961, now kept in MAU, S and WIS.

Lars Arvidsson \& Dan Nilsson collected lichens in Mauritius in April 1979 (specimens kept in GB); results, mainly on Coccocarpia, have been published by Arvidsson (1982) and Galloway \& Jørgensen (1987).

Austrian botanists Harald Riedl and Christa RiedlDorn visited Mauritius in 1981, with the aim of sampling the entire lichen flora from that country. Their specimens are kept in W, but most seem not to have been identified. Nothing has been published by them, except for a summary of their results (Riedl \& Riedl-Dorn 1986), mentioning the genera encountered, not the species. The number of cryptogamic specimens collected is about 500, the majority of them lichens (Riedl \& Riedl-Dorn 1986).

British mycologist and lichenologist David Leslie Hawksworth collected 83 lichen specimens in 1990, all kept in K-IMI. In a first paper by David \& Hawksworth (1995), the authors published, in addition to new records of a number of species, five species new to science: Cladonia mauritiana, Mycomicrothelia leuckertii, Ocellularia petrinensis, Pertusaria hymenelioides and Pertusaria muricata. They announced that the second part would deal mainly with crustose species, but that part was never published.

Norwegian lichenologists Hildur Krog (1922-2014) and Einar Timdal visited Mauritius in 1991 and collected about 1150 lichen specimens, all kept in O, with some duplicates in MAU. Some of their results were published by Timdal (2002: new genus and species Krogia coralloides) and Timdal \& Krog (2001: 11 species of Phyllopsora reported from Mauritius, including the new $P$. dolichospora and $P$. swinscowii with type localities in Mauritius).

During a 'Study Tour to the Mascarenes' in 2001, Ulrik Søchting and his students visited Perrier, the Magenta Valley, Le Pétrin, Île aux Aigrettes and Le Pouce in Mauritius. They collected around 100 specimens, kept at C, and some results based on their collections were published in Arup et al. (2013), Johannson et al. (2005), Lücking et al. (2017a), Moncada et al. (2014) and Stenroos et al. (2006). An unpublished report on the Lobariaceae was prepared by students Holm \& Gregersen (2002), and a poster presented at IMC 7 in Oslo (Holm et al. 2002).

Anders Tehler visited Mauritius in December 2003 with the main aim of collecting Arthoniales, now kept in S; results were published in Tehler \& Irestedt (2007) and Tehler et al. (2010, 2013). 
Emmanuël Sérusiaux briefly visited Mauritius in 2013 and collected in the Botanical Garden of Pamplemousses and in the forests around Pétrin and the Piton de la Petite Rivière Noire, the specimens being kept at LG; his Sticta specimens have been studied by Simon (2015) and Simon et al. (2018).

The second author of this paper, Damien Ertz, briefly visited Mauritius in 2014 and 2016 and collected about 80 lichen specimens in the Botanical Garden in Pamplemousses; those specimens are kept in BR, including the type of the new Glomerulophoron mauritiae, while duplicates of all specimens have been deposited in MAU. The first author, Paul Diederich, visited Mauritius in 2016 and collected about 375 lichen specimens; they will be kept in MAU, with duplicates in the private collection of the author. Both of us also visited Mauritius in AugustSeptember 2019 and collected about 670 (PD) +875 (DE) specimens, but only a small part of these results are included in the present paper.

\section{Rodrigues}

Scottish botanist Isaac Bayley Balfour (1853-1922) participated in the Venus-Transit Expedition to Rodrigues, where he investigated the local flora from September to December 1874 . The lichens he collected were studied by James Mascall Morrison Crombie (1830-1906) and William Nylander (1822-99), and published in three papers.

Following an anonymous note at https://plants.jstor. org/stable/10.5555/al.ap.specimen.h9510166, the paper in The Journal of Botany 14: 262-265, including short diagnoses of new species, was published in September or October 1876 (Crombie 1876a), while the paper in Journal of the Linnean Society, Botany 15: 431-445 with longer descriptions and discussions, although 'Read June 15, 1876', was published only in December 1876 (Crombie 1876b). Crombie (1876a: 262) wrote that he publishes here short diagnoses 'previous to a more detailed report', confirming that the Crombie (1876a) paper was intended to be published first. A third paper, published in Philosophical transactions of the Royal Society of London 168: 402-413 (Crombie 1879), represents a copy of Crombie (1876b) and therefore has not been considered in our checklist.

In Crombie (1876a), short diagnoses of 26 new species and one new variety were given. Crombie (1876b) gave detailed descriptions of these 27 taxa and also reported many other taxa collected in Rodrigues. This paper additionally described new infra-specific taxa not included in Crombie (1876a), such as Ramalina gracilenta f. nodulosa.

Crombie (1876a) described some new species himself, such as 'Cladonia balfourii Cromb.', but attributed others to Nylander, such as 'Usnea dasypogoides Nyl.'. Although Crombie (1876b: 432) acknowledged Nylander 'who has also kindly sent me his MS. diagnoses of the species determined by him', he failed to do so in his first paper (Crombie 1876a). Therefore the author citation for such species should be 'Nyl. ex Cromb.' or simply 'Cromb.', and not 'Nyl.' (ICN, Art. 46.5, 46.8).
Both of us visited Rodrigues in September 2019 and collected about $200(\mathrm{PD})+250(\mathrm{DE})$ specimens, but only a few of these specimens are included here.

\section{Other Isles}

In addition to the isles of Mauritius and Rodrigues, the Republic of Mauritius also comprises the outer islands of Agaléga and St. Brandon; no lichens have yet been reported from these isles, although two Ramalina specimens from Agaléga are kept in MAU. Mauritius further claims sovereignty over the uninhabited isle of Tromelin, from where no lichens have ever been reported, and the Chagos Archipelago, including Diego Garcia. The lichens from the latter archipelago were sampled by Mark Seaward during the 1996 Chagos Expedition and published in Seaward \& Aptroot (2000). These records have not been included in our checklist below.

\section{The Checklist}

The checklist is presented in alphabetical order; accepted taxa are in boldface, while dubious taxa and synonyms are not bolded and are in smaller characters; genera are 'accepted' when they include at least one accepted species; species are 'accepted' when representative specimens have been examined either by us or recently by lichen taxonomists; all other reported species for which a re-examination of relevant material is needed are considered 'dubious'. Names of taxa newly described from Mauritius (except those described in this paper) are preceded by an asterisk; when the Mauritian origin of a type is dubious, the asterisk is parenthesised $\left(^{*}\right)$. Names of lichenicolous species (except the one newly described) are preceded by a plus sign. For taxa described from Mauritius, information on types is given, as far as possible, often using online databases, such as JSTOR (https://plants.jstor.org); for species known from Mauritius, the frequency and distribution data are often completed using unpublished information from online databases of herbaria, such as the Oslo herbarium (O) (https://www.gbif.org/occurrence/ search?country=MU\&dataset_key=7948250c-6958-4a29a670-ed1015b26252); however, with a few exceptions, no attempts have been made to re-examine such types or other historical specimens reported from the country. As a rule, specimens collected by the first author are kept in MAU, with duplicates in herb. Diederich; those collected by the second author are kept in MAU, with duplicates in BR; when a single herbarium is indicated, such as '(MAU)', then there are no further duplicates; 'Diederich 18284 (dupl. LG)' means that a duplicate is kept in LG, in addition to duplicates in MAU and herb. Diederich. Taxonomic (heterotypic) synonyms are indicated by '=', nomenclatural (homotypic) synonyms by ' $\equiv$ '.

\section{ACROCORDIA A. Massal.}

gemmata (Ach.) A. Massal. [三Verrucaria gemmata (Ach.) Ach.]. The report by Daruty (1873) from Mauritius is very doubtful, as this is a temperate species unlikely to occur in the tropics. 


\section{AGONIMIA Zahlbr.}

opuntiella (Buschardt \& Poelt) Vězda

Pamplemousses: $1 \mathrm{~km}$ NNW of Botanical Garden, S of Museum 'Aventure du sucre', on bark, 2016, Diederich 18623 (MAU). Rivière Noire: Ebony Forest, viewpoint, on exposed rocks, 2019, Diederich 19392.

New for Mauritius.

\section{pacifica (H. Harada) Diederich}

Plaines Wilhems: Curepipe, Trou aux Cerfs, along road surrounding the crater, on bark, 2016, Diederich 18277 (MAU, sub Thecaria quassiicola). Rivière Noire: Trail from Plaine Champagne towards Piton de la Petite Rivière Noire, on bark, 2016, Diederich 18617 (MAU); Ebony Forest, around viewpoint, on bark, 2019, Diederich 18920. Savanne: Along trail to Mt Cocotte, on bark, 2019, Diederich 18849 \& Ertz 23507.

New for Mauritius.

\section{ALLOGRAPHA Chevall.}

angustata (Eschw.) Lücking \& Kalb [三 Graphis angustata Eschw.]. Reported from Mauritius by Daruty (1873).

\section{calcea (Fée) Lücking \& Kalb}

Plaines Wilhems: Le Pétrin, between Pétrin Information Centre and first viewpoint along trail to the west, on bark, 2016, Diederich 18352.

A pantropical species, new for Africa.

comma (Ach.) Lücking \& Kalb [三 Graphis comma (Ach.) Spreng.]. Reported from Mauritius by Daruty (1873).

laubertiana (Fée) Lücking \& Kalb [三 Opegrapha laubertiana (Fée)Bél.]. 'Sur l'écorce des arbres, à l'île Maurice' (Bélanger 1834).

\section{rimulosa (Mont.) Lücking \& Kalb}

Pamplemousses: Jardin Botanique, on bark of Agathis robusta, 2016, Ertz 21483. Savanne: Road from Le Pétrin to Chamouny, beginning of trail to Montagne Cocotte, on branches, 2016, Diederich 18374.

A pantropical species, new for Africa.

\section{rustica (Kremp.) Lücking \& Kalb}

*= Graphis turgidula Müll. Arg., J. Linn. Soc., Bot. 30: 457 (1895). Type: Mauritius, summit of Mt Pouce, corticolous, Ayres (BM, lectotype; G-00047548, G-00047547, isolectotypes) (Archer 2006: 83, Archer 2009: 141, Wirth \& Hale 1978: 24).

Port Louis and Moka: Along trail from Moka to Le Pouce, on bark, 2019, Ertz 24118 (TLC: stictic, hypostictic, unknown terpenoid, solvent $\mathrm{A}$ ).

striatula (Ach.) Lücking \& Kalb

Pamplemousses: Jardin Botanique, on bark, 2016, Diederich 18258 (TLC: no substance detected, solvent A). New for Mauritius.

AMANDINEA M. Choisy ex Scheid. $\&$ M. Mayrhofer

efflorescens (Müll. Arg.) Marbach

Moka: Réduit, close to Mauritius Herbarium building, on bark of Mangifera, 2019, Diederich 18691 \& Ertz 23247.
Rivière Noire: E of Flic-en-Flac, Casela Nature Park, on bark, 2016, Diederich 18315; La Preneuse (between Tamarin and Grande Rivière Noire), cemetery, on bark at the base of a tree, 2016, Diederich 18387; Le Morne Peninsula, S coast, on bark of Casuarina, 2019, Diederich 19446.

New for Mauritius.

\section{ANAPTYCHIA Körb.}

cinerascens (Nyl.) Dodge var. pulvinigera (Müll. Arg.) Dodge. Reported from Rodrigues, 1874, Balfour, by Dodge (1971: 212).

comosa (Eschw.) A. Massal. $\equiv$ Heterodermia comosa

leucomelaena (L.) A. Massal. 三Leucodermia leucomelos

speciosa (Wulfen) A. Massal. $\equiv$ Heterodermia speciosa

\section{ANISOMERIDIUM (Müll. Arg.) Choisy}

\section{anisolobum (Nyl.) Aptroot}

Rivière Noire: Chamarel, Ebony Forest, close to park buildings, on bark, 2016, Diederich 18536; east of Black River, from Visitor's Centre to Pilgrims Trail, on bark, 2016, Diederich 18486.

New for Mauritius.

ANTHRACOTHECIUM Hampe ex A. Massal. borbonicum (Nyl.) Müll. Arg. = Anthracothecium prasinum

denudatum (Nyl.) Müll. Arg. [三 Verrucaria denudata Nyl.]. Reported from Mauritius by Daruty (1873), and from Rodrigues, on bark of trees, 1874, Balfour 2244, by Crombie (1876b).

prasinum (Eschw.) R. C. Harris [= A. borbonicum (Nyl.) Müll. Arg.]. Reported from Mauritius by Dodge (1964: 17).

\section{ARTHONIA Ach.}

atra (Pers.) A. Schneid. [三Opegrapha atra Pers.]. 'Sur les bois morts, dans les forêts de l'Ile-de-France' (Bélanger 1834, as $O$. atra var. abbreviata Flörke).

*dendritella Nyl. ex Cromb., J. Bot. 14: 264 (1876). Type: Rodrigues, on thin bark of trees, 1874, Balfour, 2300 (BM, H) (Crombie 1876a, b).

obscura Ach. 'Sur l'écorce des arbres, aux îles Maurice et de Bourbon, et dans la péninsule indienne' (Bélanger 1834).

"phylloica Nyl. ex Cromb., J. Bot. 14: 264 (1876). Type: Rodrigues, 'foliicole' (Crombie 1876a) or 'on thin stems' (Crombie 1876b), 1874, Balfour 2226 (BM, H) (Crombie 1876a, b).

spectabilis Flot. $\equiv$ Arthothelium spectabile

*ulcerosula Wedd. ex Nyl., Bull. Soc. linn. Normandie, sér. 2, 7: 174 (1874 ['1873']); 三 Arthonia ulcerulosa Wedd., in Daruty, Trans. Roy. Soc. Arts Mauritius, n.s. 7: 163 (1873), nom. nud. Type: 'Corticola in insula Mauritii'.

\section{ARTHOPYRENIA A. Massal.}

*quinqueseptatula (Nyl. ex Cromb.) Zahlbr., Cat. Lich. Univ. 1: 335 (1922); 三 Verrucaria quinqueseptatula Nyl. ex Cromb. [as Verrucaria 5-septatula], J. Bot. 14: 265 (1876). Type: Rodrigues, on the thin epidermis of bark of trees, 1874 , Balfour 2352 (BM, H) (Crombie 1876a, b). 
ARTHOTHELIUM (Vain.) Zahlbr.

spectabile A. Massal. [三 Arthonia spectabilis (A. Massal.) Anzi]. The report from Mauritius by Daruty (1873) is very doubtful, as this is a temperate species.

\section{ASTROTHELIUM Eschw.}

phlyctaenum (Fée) Aptroot \& Lücking [= Verrucaria macrozoma Fée]. 'Sur l'écorce des arbres, dans les forêts du Carnatic et de l'île Maurice' (Bélanger 1834). Verrucaria macrozoma is a synonym of Trypethelium catervarium (Fée) Tuck. (fide Awasthi 1965), of which the current name is Astrothelium phlyctaenum (fide Aptroot et al. 2016: 997).

\section{BACIDINA Vězda}

medialis (Nyl.) Kistenich, Timdal, Bendiksby \& S. Ekman Pamplemousses: Jardin Botanique, on bark, 2016, Diederich 18256, 18582. Rivière Noire: East of Black River, from Visitor's Centre to Pilgrims Trail, on bark, 2016, Diederich 18503.

New for Mauritius.

\section{BACTROSPORA A. Massal.}

cf. myriadea (Fée) Egea \& Torrente. Reported from Mauritius by Crittenden et al. (1995).

\section{BAIDERA Ertz \& Diederich, gen. nov.}

\section{MycoBank MB 834917}

Diagnosis: A genus of Roccellaceae characterized by a thick, crustose, ecorticate, compact thallus, lirelliform ascomata with a carbonized lecideine excipulum, a carbonized hypothecium extending down to the substrate, a pruinose and not tomentose hymenial disc, ascospores without a distinct gelatinous sheath and the psoromic acid chemosyndrome.

Generic type: Baidera mauritiana Ertz \& Diederich.

Description. Thallus crustose, thick, compact, ecorticate. Photobiont trentepohlioid. Ascomata lirelliform; ascomatal margin lecideine; hymenial disc pruinose, not tomentose; excipulum dark brown to carbonized; hypothecium dark brown to carbonized, extending down to the substrate; hymenium $\mathrm{K} / \mathrm{I}+$ pale blue; paraphysoids mostly simple, sometimes branched (mainly in epihymenium), with a slightly enlarged apical cell; asci narrowly clavate, with a $\mathrm{K} / \mathrm{I}+$ blue internal wall (in particular when young), and a K/I+ blue ring around a tiny ocular chamber (Abieti$n a$-type according to Egea \& Torrente 1994). Ascospores hyaline, fusiform, straight, without a distinct gelatinous sheath. Conidiomata pycnidial; conidiogenous cells simple, straight; conidia hyaline, simple. Chemistry: psoromic acid chemosyndrome.

Notes. The new genus forms a distinct lineage in the family Roccellaceae, being somewhat related to the genera Gyrographa and Sigridea, but relationships between these genera are not supported (Fig. 4). It differs from all genera of Roccellaceae by the combination of a thick crustose, not byssoid thallus, lirelliform ascomata with a carbonized excipulum not covered by a thalline layer, a carbonized hypothecium extending down to the substrate, a pruinose and not tomentose hymenial disc, ascospores without a distinct gelatinous sheath, and a chemistry with psoromic acid as major substance. The genus is reminiscent of Lecanographa, but species of the latter have ascospores with a distinct gelatinous sheath, an ascus of the
Grumulosa-type, and they belong to a distinct lineage in the family Lecanographaceae.

Etymology. The new genus is dedicated to Cláudia Baider, curator of the Mauritius Herbarium (MAU), as an acknowledgement of her valuable help to us in exploring the lichens of Mauritius. Cláudia is very interested in the conservation of biodiversity in tropical terrestrial systems, in the impact of alien species in tropical forests, and in the restoration ecology and taxonomy of Mascarene flowering plants.

Baidera mauritiana Ertz \& Diederich, sp. nov.

(Figs 3-4)

\section{MycoBank MB 834918}

Diagnosis: The only species of Baidera is characterized by a pale greyish, almost white thallus, ascomata of 0.25-2.7 $\times 0.19-0.29 \mathrm{~mm}, \mathrm{a} \mathrm{K}+$ olivaceous green excipulum and 3(-4)-septate ascospores of 25-35 × 4.5-6.0 $\mu \mathrm{m}$.

Type: Mauritius, Pamplemousses district, Pamplemousses, Sir Seewoosagur Ramgoolam Botanical Garden, $20^{\circ} 06^{\prime} 21^{\prime \prime} \mathrm{S}$, $57^{\circ} 34^{\prime} 49^{\prime \prime} \mathrm{E}$, alt. $80 \mathrm{~m}$, on bark of Mangifera, 29 Dec. 2016, Ertz 21443 (MAU - holotype, BR, herb. Diederich - isotypes).

Description. Thallus 50-280 $\mu \mathrm{m}$ thick, continuous, pale greyish, almost white, \pm smooth to rough, sometimes with areas appearing bullate, rimose to areolate, esorediate or rarely with whitish soredia, non-isidiate; medulla containing crystals (1-8 $\mu \mathrm{m}$ diam.) of calcium oxalate (tested with $25 \% \mathrm{H}_{2} \mathrm{SO}_{4}$ ), I+ red; hyphae hyaline, 1.5-2 $\mu \mathrm{m}$ diam., I+ orange; prothallus dark brown, $0.1-0.5 \mathrm{~mm}$ wide. Photobiont cells elongated, $\sim 6-14 \times 5-10 \mu \mathrm{m}$. Ascomata lirelliform, simple, rarely with one ramification, semi-sessile, without constricted base, straight to strongly flexuose $0.25-2.0(-2.7)$ $\times 0.19-0.29 \mathrm{~mm}$, scattered or densely distributed; ascomatal margin prominent, slightly raised above the level of the hymenial disc, black, \pm smooth, \pm glossy; hymenial disc black, \pm smooth, plane, covered by a thin layer of white pruina; excipulum $42-50 \mu \mathrm{m}$ thick laterally, $\mathrm{K}+$ olivaceous green; hypothecium $85-175 \mu \mathrm{m}$ thick, $\mathrm{K}+$ olivaceous green; hymenium not inspersed, pale yellowish to almost hyaline, 75-85 $\mu \mathrm{m}$ tall, I+ dark red; subhymenium $\sim 10-15 \mu \mathrm{m}$ thick, $\mathrm{I}+$ pale blue in parts; epihymenium pale orange-brown, I+ pale orange to pale blue, $\mathrm{K}$ - (becoming almost hyaline); paraphysoids mostly simple, sometimes branched (mainly in epihymenium), 1.5-2 $\mu \mathrm{m}$, with a slightly enlarged and pale orange-brown apical cell of $2-3 \mu \mathrm{m}$ in diameter; asci 8-spored, 65-70 × 13-15 $\mu \mathrm{m}$. Ascospores 3(-4)-septate, $(25-) 25.4-30.7(-35) \times(4.5-) 4.8-5.7(-6) \mu \mathrm{m}$, ratio $\mathrm{L} / \mathrm{B}$ $(4.6-) 4.9-5.9(-6.4)(\mathrm{n}=26)$. Conidiomata either prominent, $0.3-1 \mathrm{~mm}$ diam, with a thick thallus border and pore-like to short slit-like, slightly exposed, pale to dark brown opening, or immersed; wall rather inconspicuous, $\sim 10 \mu \mathrm{m}$ thick, pale yellowish; conidiogenous cells $\sim 5-8 \times 1.5-2 \mu \mathrm{m}$; conidia straight, rarely slightly curved, $4-6 \times 1.5(-2) \mu \mathrm{m}$. Chemistry: thallus $\mathrm{K}-, \mathrm{C}-, \mathrm{KC}-, \mathrm{PD}+$ distinctly yellow, $\mathrm{UV}-$; psoromic (major) and three \pm fatty acids of Rf 7, 10 and 17 detected by TLC (solvent B').

Ecology and distribution. The species is known from two localities in Mauritius, where it grows on the bark of big trees in parkland conditions.

Notes. The new species is unique in having a thick pale greyish thallus containing psoromic acid, the lirelliform ascomata with a carbonized $\mathrm{K}+$ olivaceous green excipulum, an exposed whitish pruinose hymenial disc, and 3-septate 

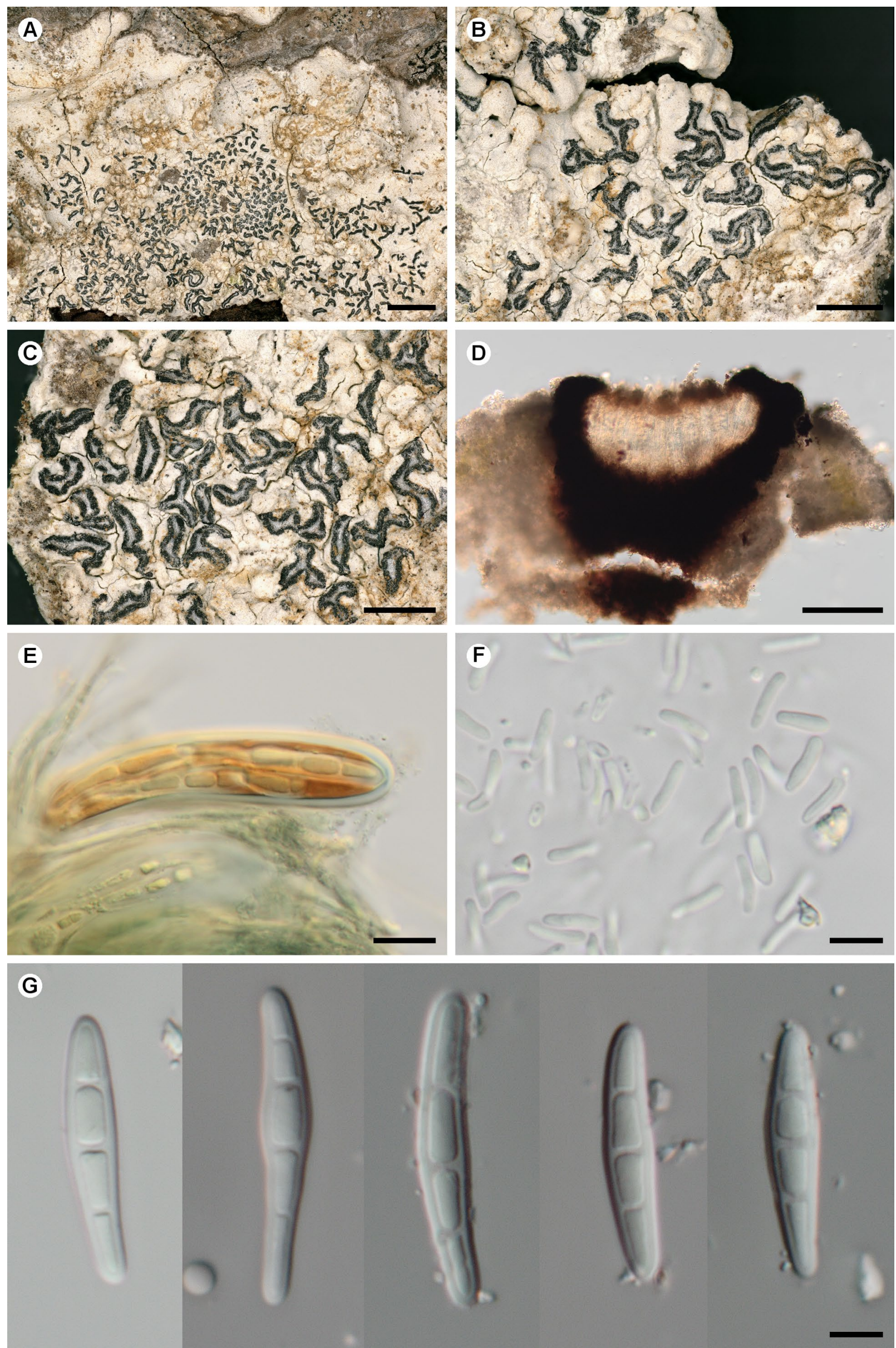

Figure 3. Baidera mauritiana [holotype]. A-C - thallus and ascomata; D - section of ascoma, in water; E - asci, in KI; F - conidia, in water; $\mathrm{G}$ - ascospores, in water. Scale bars: $\mathrm{A}=2.5 \mathrm{~mm} ; \mathrm{B}-\mathrm{C}=1 \mathrm{~mm} ; \mathrm{D}=100 \mu \mathrm{m} ; \mathrm{E}=10 \mu \mathrm{m} ; \mathrm{F}-\mathrm{G}=5 \mu \mathrm{m}$. Photos: D. Ertz. 
large ascospores lacking a gelatinous sheath. Lecanactis californica is similar to our new species by the presence of psoromic acid and 3-septate ascospores, but differs by more roundish, unbranched, wider ascomata that are constricted at the base, slightly shorter ascospores $(20-28 \mu \mathrm{m})$, and filiform conidia 5-6 $61 \mu \mathrm{m}$ (Egea \& Torrente 1994). The new species is reminiscent of Lecanographa, a genus in which L. follmanii appears to be the most similar to our new species, but it differs by much narrower ascospores (3-3.5 $\mu \mathrm{m}$ wide) with a distinct gelatinous sheath. Specimens Diederich
18734, 18741 and Ertz 21486 have only pycnidia, while specimen Diederich 18246 is sorediate.

Etymology. The specific epithet refers to the occurrence in Mauritius.

Additional specimens examined. MAURITIUS. Pamplemousses: Pamplemousses, Sir Seewoosagur Ramgoolam Botanical Garden, $80 \mathrm{~m}, 20^{\circ} 06^{\prime} 21^{\prime \prime} \mathrm{S}, 57^{\circ} 34^{\prime} 49^{\prime \prime} \mathrm{E}$, on bark of a big tree, 2016, Ertz 21486 (pycnidia only); ibid., $20.10631^{\circ} \mathrm{S}$,

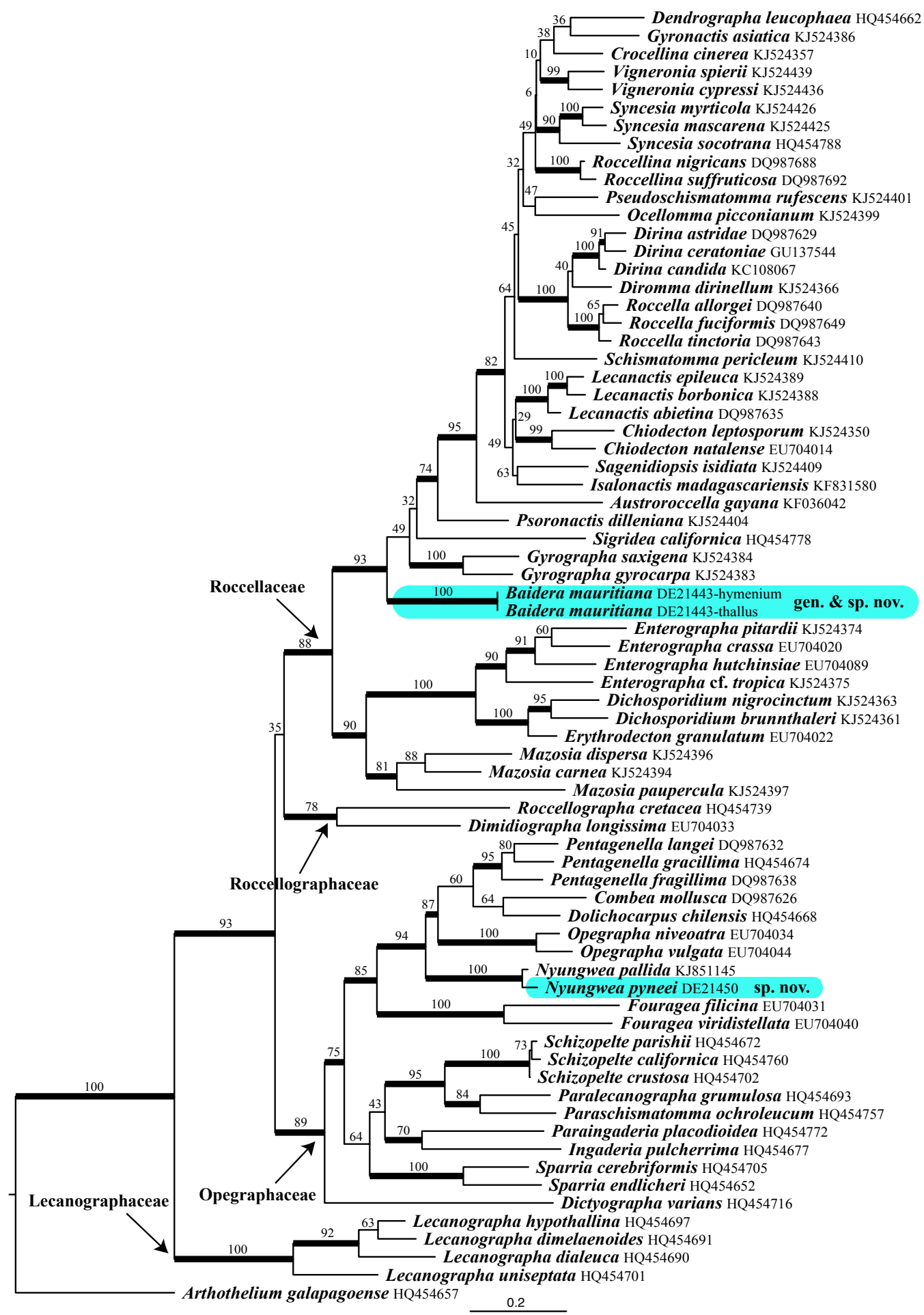

Figure 4. Phylogeny of Arthoniales based on a data set of RPB2 sequences that resulted from a RAxML analysis. Maximum likelihood bootstrap values are shown above or near internal branches. Internal branches, considered strongly supported by both the RAxML and Bayesian analyses, are represented by thicker lines. The newly sequenced samples from Mauritius are highlighted and their names followed by collecting numbers of authors, which act as specimen and sequence identifiers. 
$57.58133^{\circ} \mathrm{E}$, on bark of trees, 2016, Diederich 18246 (fertile and sorediate). Moka: Réduit, State House Park, on bark, 2019, Diederich 18734, 18741, 18742 \& Ertz 23312.

\section{BIATORA Ach.}

leucoxantha (Spreng.) Bél. $\equiv$ Brigantiaea leucoxantha

\section{BIATOROPSIS Räsänen}

Biatoropsis millanesiana Diederich \& Wedin, sp. nov.

\section{MycoBank MB 834919}

Diagnosis: Characterized by large, brown, relatively dark basidiomata, and 3-septate basidia with the three lower cells laterally often elongating at maturity.

Type: Mauritius, Rivière Noire, Chamarel, Ebony Forest, around viewpoint, $20^{\circ} 25^{\prime} 49^{\prime \prime} \mathrm{S}, 57^{\circ} 22^{\prime} 27^{\prime \prime} \mathrm{E}$, alt. $350 \mathrm{~m}$, on branches of trees, on Usnea exasperata s. 1., 8 Aug. 2016, Diederich 18524 (MAU - holotype, BR, MAF, S, herb. Diederich - isotypes).

Description. Basidiomata inducing the formation of convex, basally constricted galls, sometimes slightly tuberculate when mature, waxy gelatinous when wet, pale brown to more frequently dark brown or blackish, $(0.3-) 0.6-1.5(-2.5)$ $\mathrm{mm}$ diam. Context hyphae thin-walled, $2-3 \mu \mathrm{m}$ diam., clamp connections not observed. Haustorial branches frequent, mother cell spherical to subspherical, 4-6 $\times 3-4 \mu \mathrm{m}$, haustorial filament $1-1.5 \mu \mathrm{m}$ diam. Hymenium hyaline, containing numerous probasidia; probasidial initials clavate to subcylindrical; basal clamp not observed. Basidia, when mature, 4-celled, with three transverse septa, not or slightly constricted at the septa, the lower cell with an attenuated stalk-like base, often longer than the upper cells, 21-72 $\times 4-10 \mu \mathrm{m}$ (incl. stalk-like base, excl. epibasidia), lower part of the stalk-like base 2-4 $\mu \mathrm{m}$ diam.; the three lower cells laterally much elongate at maturity, sometimes giving the appearance of immature independent basidia, 4-6 $\mu \mathrm{m}$ thick. Epibasidia up to $50 \mu \mathrm{m}$ long. Basidiospores globose to ellipsoid, (4-)5-8 × (5.5-)6-9(-11) $\mu \mathrm{m}$, ratio L/B 0.6-1, with a distinct apiculus, $\sim 1 \mu \mathrm{m}$ diam. Asexual morph not observed.

Hosts and distribution. Lichenicolous on the thallus of U. exasperata s. 1., on which it is very abundant in Mauritius, Rodrigues and the Seychelles (Praslin) in the Indian Ocean. Usnea exasperata currently seems to represent a heterogeneous assemblage of several species, but no taxonomic and phylogenetic revision is available yet to identify them.

Notes. Millanes et al. $(2014 ; 2016)$ recognized an independent evolving lineage provisionally named Biatoropsis sp. F. Specimens from this clade were reported from Usnea ceratina, U. exasperata, U. hirta and U. rubicunda. Millanes et al. (2016) 'have not been able to identify any morphological or ecological characters that could distinguish specimens in this clade from Biatoropsis usnearum s.str.' and preferred to wait for a formal description until more material is available. Our rich material from several localities in Mauritius, incl. Rodrigues, allowed us to better understand the phylogenetic relationships between the specimens included in $B$. sp. F (Fig. 6). Our results show that the clade formerly recognized as Biatoropsis sp. F represents in reality at least two distinct species, one confined to Usnea exasperata s.lat. in the Indian Ocean, and another one on U. rubicunda (with a further specimen known from $U$. ceratina [host identified by C. Truong; TLC: diffractaic]). Populations on $U$. hirta reported from Arizona by Millanes et al. (2016) are not considered here, owing to the deviating morphology of basidiomatal galls (broad, almost disk-like, concolorous to the host thallus), and will be treated elsewhere.

The available nice and richly fertile material from Mauritius and Rodrigues pemits us to describe the species formally here. The main characterizing feature may be the 3 -septate basidia, in which the three lower cells elongate laterally at maturity, giving the appearance of several individual aseptate basidia (Fig. 5I). Such basidia had not been observed in the Seychelles specimen by Millanes et al. (2016), and rich fertile material seems to be needed to observe them. Similar basidia are also known from Biatoropsis hafellneri, a species confined to the Usnea fragilescens aggregate, but in that species they are always 1-septate, and basidiomata are pale orange or brown. Basidiomata of Biatoropsis minuta are always smaller, $0.1-0.8 \mathrm{~mm}$ diam., and this species is known only from the two related Usnea barbata and U. lapponica. Biatoropsis protousneae has large, often flattened basidiomata and is confined to Protousnea dusenii. Biatoropsis usnearum s.str. has large basidiomata ranging from pale brown to blackish, but typically pinkish to orange-brown; European specimens appear to grow exclusively on the Usnea florida/subfloridana complex, while populations from other continents are more diverse regarding host selection (Millanes et al. 2016).

Crombie (1876b) described the new Usnea dasypogoides from Rodrigues and mentioned that 'scattered «cephalodia» not unfrequently occur', suggesting basidiomata of the new Biatoropsis. However, no such basidiomata are seen in online photographs of syntypes of $U$. dasypogoides in $\mathrm{E}, \mathrm{G}$ and $\mathrm{H}$.

Etymology. The new species is dedicated to our friend Ana Millanes, mycologist at King Juan Carlos University, Madrid, to honour her huge contribution to the study and knowledge of heterobasidiomycetes in general and especially of lichenicolous Tremellales.

Additional specimens examined. MAURITIUS (all on Usnea exasperata s. 1.). Plaines Wilhems: Curepipe, Curepipe Botanic Gardens, 2016, Diederich 18291 (specimen kept under $U$. exasperata $\mathrm{s}$. 1.). Rivière Noire: Same locality as type, 2019, Diederich 18921 \& Ertz 23556A. Rodrigues: $\mathrm{N}$ of Grande Montagne, near road bifurcation W of Brûlé, 2019, Diederich 18979 \& Ertz 23805 (sub Usnea); Grande Montagne Nature Reserve, 2019, Diederich 18997 \& Ertz 23722, 23723; SE of Mont Lubin, Mont Limon, near the top, 2019, Diederich 19029. SEYCHELLES. Praslin: Praslin National Park, SE of Vallée de Mai, along trail to Glacis Noir and fire tower, $4^{\circ} 20.23^{\prime} \mathrm{S}, 55^{\circ} 44.58^{\prime} \mathrm{E}$, 2015, Diederich 18087B (SEY, herb. Diederich).

\section{BILIMBIA De Not.}

lobulata (Sommerf.) Hafellner \& Coppins [三Lecanora murorum var. lobulata (Sommerf.) Schaer.]. Reported from Rodrigues, on rocks, 1874, Balfour 2350, by Crombie (1876b).

\section{BOGORIELLA Zahlbr.}

"leuckertii (D. Hawksw. \& J. C. David) Aptroot \& Lücking Lichenologist 48: 911 (2016); झ Mycomicrothelia leuckertii D. Hawksw. \& J. C. David, in David \& Hawksworth, Biblioth. Lichenol. 57: 98 (1995). Type: Plaines Wilhems, Vacoas, ingressus sylvae Macchabeae, on bark of Syzygia jambosa, 11 June 1990, Hawksworth (K-IMI 400619, 
holotype) (David \& Hawksworth 1995; Crittenden et al. 1995; Aptroot \& Lücking 2016: 911)

thelena (Ach.) Aptroot \& Lücking [三 Verrucaria thelena Ach.]. 'Sur l'écorce des Rubiacées et particulièrement sur celle des Ixora, sur celle des Strychnos et de plusieurs Térébinthacées' (Bélanger 1834).
$\boldsymbol{B R I G} \boldsymbol{A} \boldsymbol{N T I} \boldsymbol{A} \boldsymbol{E} \boldsymbol{A}$ Trevis., nom. rej.

leucoxantha (Spreng.) R. Sant. \& Hafellner

$\equiv$ Biatora leucoxantha (Spreng.) Bél.; 三Lopadium leucoxanthum (Spreng.) Zahlbr.

Rivière Noire: Trail from Plaine Champagne towards Piton
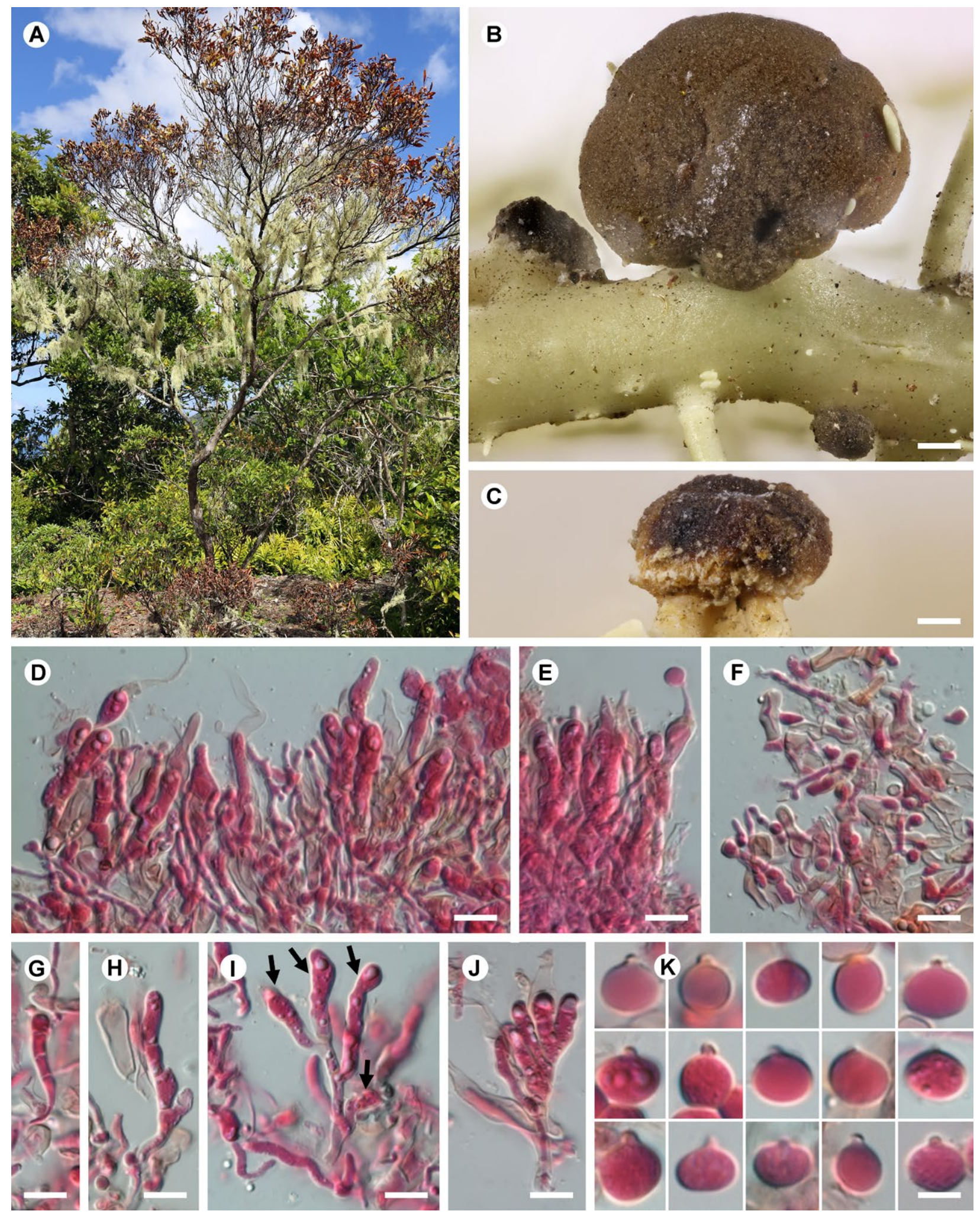

Figure 5. Biatoropsis millanesiana [holotype]. A - type locality in Mauritius; $\mathrm{B}-\mathrm{C}$ - basidiomata; D-E - hymenium, showing basidia, epibasidia and one basidiospore attached to an epibasidium; F - haustorial branches; $\mathrm{G}$ - young, 3-septate basidium; H - basidium with laterally slightly elongate cells; I-J - mature basidia with four laterally elongate and diverging cells (in I shown by arrows); $\mathrm{K}-$ basidiospores. D-K in a mixture of 5\% KOH, phloxine B and Congo Red. Scales: B-C $=200 \mu \mathrm{m}$; D-J $=10 \mu \mathrm{m} ; \mathrm{K}=5 \mu \mathrm{m}$. Photos: P. Diederich. 


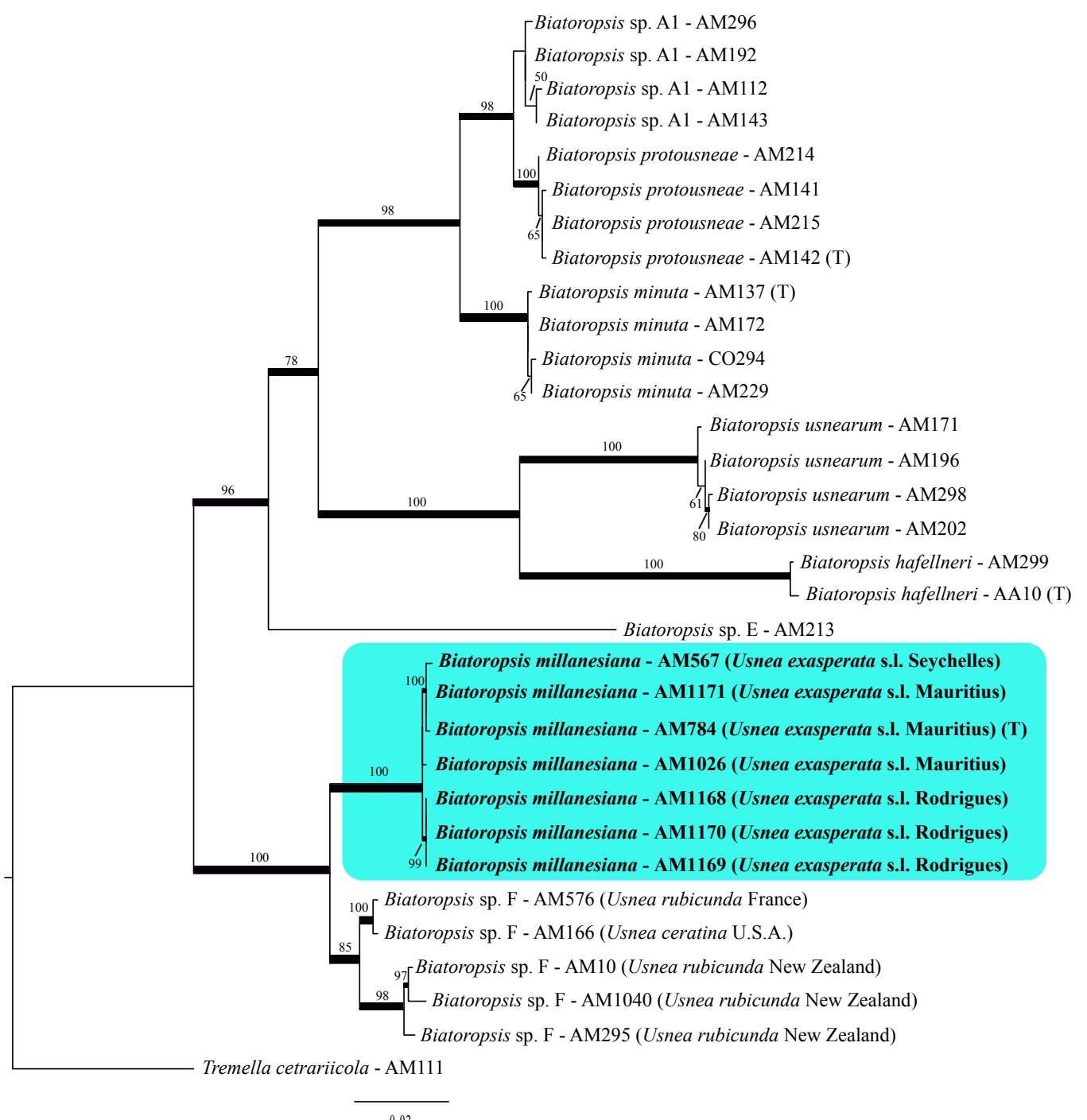

Figure 6. Phylogram showing the position of the new species Biatoropsis millanesiana (blue box), based on ITS and nuLSU sequences, corresponding to the best tree recovered in the maximum likelihood analysis, with information on ML bootstrap values added. Thick branches indicate nodes with ML bootstrap values over $75 \%$. Type specimens are indicated by (T).

de la Petite Rivière Noire, on bark, 2016, Diederich 18421, 18422; Chamarel, Ebony Forest, along trail W of viewpoint, on bark, 2019, Ertz 23586. Port Louis and Moka: Along trail from Moka to Le Pouce, on bark, 2019, Ertz 24048.

Previously reported from Mauritius 'Sur les bois morts' by Bélanger (1834), by Lindau (1908), from BM, G and $\mathrm{H}$ by Hafellner (1997: 55), and from Rodrigues (BM) by Hafellner (1997: 55).

tricolor (Mont.) Trevis. Hafellner (1997: 71) wrote under Lecidea leucoxantha var. ochrocarpa that 'Until now only B. tricolor has been found in Mauritius'. This is certainly a lapsus, as this author reported having studied several specimens of B. leucoxantha from Mauritius and Rodrigues, while $B$. tricolor is known from Madagascar and Reunion but not from Mauritius.

BROWNLIELLA S. Y. Kondr., Kärnefelt, Elix, A. Thell \& Hur

cinnabarina (Ach.) S. Y. Kondr., Kärnefelt, A. Thell, Elix, J. Kim, A. S. Kondr. \& Hur [三 Caloplaca cinnabarina (Ach.) Zahlbr., 三 Lecanora cinnabarina Ach.]. Reported from Rodrigues, on rocks, 1874, Balfour 2301, by Crombie (1876b).

\section{BUELLIA De Not.}

*continens (Nyl. ex Cromb.) Zahlbr., Cat. Lich. Univ. 7: 346 (1931); 三Lecidea continens Nyl. ex Cromb., J. Bot. 14: 264 (1876). Type: Rodrigues, on rocks, 1874, Balfour 2343 (BM, H) (Crombie 1876a, b).

geophila (Flörke ex Sommerf.) Lynge [= Lecidea triphragmia Nyl.]. Reported from Rodrigues, on bark of trees, 1874, Balfour 2368, by Crombie (1876b).

*immutans (Nyl. ex Cromb.) Zahlbr., Cat. Lich. Univ. 7: 368 (1931); 三 Lecidea immutans Nyl. ex Cromb., J. Bot. 14: 264 (1876). Type: Rodrigues, on rocks, 1874, Balfour 2221 (BM, H) (Crombie 1876a, b).

spuria (Schaer.) Anzi [三 Lecidea spuria Schaer.]. Reported from Rodrigues, on rocks, 1874, Balfour 2351, by Crombie (1876b).

\section{BULBOTHRIX Hale}

aff. johannis D. M. Masson, Benatti \& Sérus.

Plaines Wilhems: Le Pétrin, along trail W of Pétrin Information Centre, up to $600 \mathrm{~m} \mathrm{~W}$ of first viewpoint, on bark, 
2019, Diederich 18768. Savanne: Along trail to Mt Cocotte, on bark, 2019, Diederich 18886.

Reported by Masson et al. (2015) from Plaines Wilhems, near Midlands, Vaughan L/6 (BM) (Hale 1976: 24, as B. suffixa), along the path from Plaine Champagne towards Piton de la Petite Rivière Noire, 1991, Krog \& Timdal (O), Le Pouce, 1991, Krog \& Timdal (O), Pétrin heath, 1991, Krog \& Timdal (O), and Mt Cocotte, 1991, Krog \& Timdal (O).

Following Masson et al. (2015), the material from Mauritius probably is a taxon different from $B$. johannis but phylogenetically closely related to it.

suffixa (Stirt.) Hale. The Mauritius specimen previously published under this name by Hale (1976) was referred to Bulbothrix aff. johannis by Masson et al. (2015). The report from Mt Cocotte, 1991, Krog \& Timdal (O) (Lücking \& Timdal 2016: 194) almost surely also refers to $B$. aff. johannis.

\section{BUNODOPHORON A. Massal.}

australe (Laurer) A. Massal. [三 Sphaerophorus australis Laurer]. Reported from Mauritius 'auf Erde' by Lindau (1908).

melanocarpum (Sw.) Wedin [= Sphaerophorus compressus Ach.]. Reported from Mauritius by Daruty (1873, sub 'Sphaerophoron compressum').

\section{BYSSOCAULON Mont.}

molliusculum Nyl. $\equiv$ Crocynia molliuscula

\section{CALOPLACA Th. Fr.}

*aurantiella (Nyl. ex Cromb.) C. Moreau \& M. Moreau, Rev. Bryol. Lichén. 20: 193 (1951); 三 Lecanora aurantiella Nyl. ex Cromb., J. Bot. 14: 263 (1876). Type: Rodrigues, on rocks, 1874, Balfour 2317 (BM, H) (Crombie 1876a, b).

bassiae (Ach.) Zahlbr. $\equiv$ Gyalolechia bassiae

cinnabarina (Ach.) Zahlbr. $\equiv$ Brownliella cinnabarina

*diplacia var. carneofusca (Nyl. ex Cromb.) Zahlbr., Cat. Lich. Univ. 7: 114; 三Lecanora carneofusca Nyl. ex Cromb., J. Bot. 14: 263 (1876). Type: Rodrigues, on rocks, 1874, Balfour 2293 (BM, H, M, UPS-L049836) (Crombie 1876a, b).

"glaucofuscula (Nyl. ex Cromb.) Zahlbr., Cat. Lich. Univ. 7: 141 (1930); E Lecanora glaucofuscula Nyl. ex Cromb., J. Bot. 14: 263 (1876). Type: Rodrigues, on rocks, 1874, Balfour 2216 (BM, H) (Crombie 1876a, b).

*Lecanora glaucofuscula f. biatoroidea Cromb., Journ. Linn. Soc., Bot. 15: 437 (1876). Type: Rodrigues, on rocks, 1874, Balfour (BM). Probably belongs to Caloplaca s.lat. but has never been combined there.

saxicola $($ Hoffm.) Nordin [= Placodium murorum DC.]. Reported from Mauritius (herb. Fée) by Nylander (1859: 257).

\section{CELOTHELIUM A. Massal.}

\section{${ }^{*}$ Tomasellia zollingeri Müll. Arg.}

Hedwigia 31: 287 (1892). Type: Summit of Pouce (BM; G 00294851, syntypus).

Müller (1892) suggested that this species belongs to $\mathrm{Ce}$ lothelium, a view shared by Aguirre-Hudson (1991). David \& Hawksworth (1995: 105) examined the BM specimen 'found to belong to Celothelium, however the nature of its relationship with $C$. aciculifera (Nyl.) Vain. has to be clarified and will be included in a further paper'.

\section{CETRARIA Ach.}

aculeata (Schreb.) Fr. The report from Mauritius by Daruty (1873) almost surely refers to specimen Bojer (MAU L1885!, sub C. aculeata), which belongs to Cladia gorgonea.

\section{CETRELIA W. L. Culb. \& C. F. Culb.}

olivetorum (Nyl.) W. L. Culb. \& C. F. Culb. [三 Parmelia olivetorum Nyl.]. Reported from Mauritius by Daruty (1873).

\section{CHAPSA A. Massal.}

\section{alborosella (Nyl.) A. Frisch}

Plaines Wilhems: Le Pétrin, between Pétrin Information Centre and first viewpoint along trail to the west, on a branch, 2016, Diederich 18354.

A pantropical species, new for Mauritius.

\section{Chapsa alletii Diederich \& Ertz, sp. nov.}

MycoBank MB 834920

Diagnosis: Characterized by apothecia $0.8-2 \mathrm{~mm}$ diam., a white pruinose disc, a margin with a bright red, $\mathrm{K}+$ green inner surface, and hyaline, 4-7-septate ascospores, 13.5-19 $\times 4.5-5 \mu \mathrm{m}$.

Type: Mauritius, Plaines Wilhems, Black River Gorges National Park, Le Pétrin, between Pétrin Information Centre and first viewpoint along trail to the west, $20.4019^{\circ} \mathrm{S}( \pm 1000 \mathrm{~m})$, $57.4588^{\circ} \mathrm{E}( \pm 300 \mathrm{~m})$, alt. $610-680 \mathrm{~m}$, on a branch of a tree, 1 Aug. 2016, Diederich 18602 (MAU - holotype).

Description. Thallus light brown, smooth to uneven; cortex 10-20 $\mu \mathrm{m}$ thick, dense, formed of periclinal hyphae; photobiont layer and medulla with irregularly dispersed clusters of calcium oxalate crystals. Apothecia immersed, angular-rounded, 0.8-2 mm diam.; disc exposed, flesh-coloured, covered by a white to pink pruina especially dense in the centre and thus appearing as whitish, occasionally reddish in the centre; margin fused with the exciple, lobulate, lobes recurved, with a bright red inner surface, red pigment $\mathrm{K}+$ green. Columella absent. Excipulum prosoplectenchymatic, reddish brown, $\mathrm{K}+$ green; periphysoids present, distinct, 10-25 $\mu \mathrm{m}$ long. Hymenium 50-80 $\mu \mathrm{m}$ high, clear; epihymenium hyaline or brownish, granulose; paraphyses unbranched, $1.5-2.5 \mu \mathrm{m}$ thick, apically not or slightly swollen, not spinulose, surrounded by minuscule granules. Asci 8-spored, 45-60 × 9.5-15 $\mu \mathrm{m}$. Ascospores when young thin-walled, when mature fusiform to narrowly ellipsoid, colourless, 4-7-septate, with relatively thick septa and ellipsoidal lumina, $13.5-19 \times 4.5-5 \mu \mathrm{m}$, I-, often surrounded by a relatively thin halo. Pycnidia not observed. Chemistry: because of the rather small size of the single specimen, no TLC has been done; however, the red, K+ green pigment of the apothecial margin most probably represents isohypocrelline, known from similarly coloured Cruentotrema species (Rivas Plata et al. 2012).

Ecology and distribution. The only known specimen grows on the bark of a $7 \mathrm{~mm}$ thick branch of a tree in an disturbed and open forest. It was collected along a trail on the west of Le Pétrin and should be searched for in similar habitats in Mauritius.

Notes. The new species is remarkable and distinct from all known Chapsa species by its bright red, $\mathrm{K}+$ green apothecial 

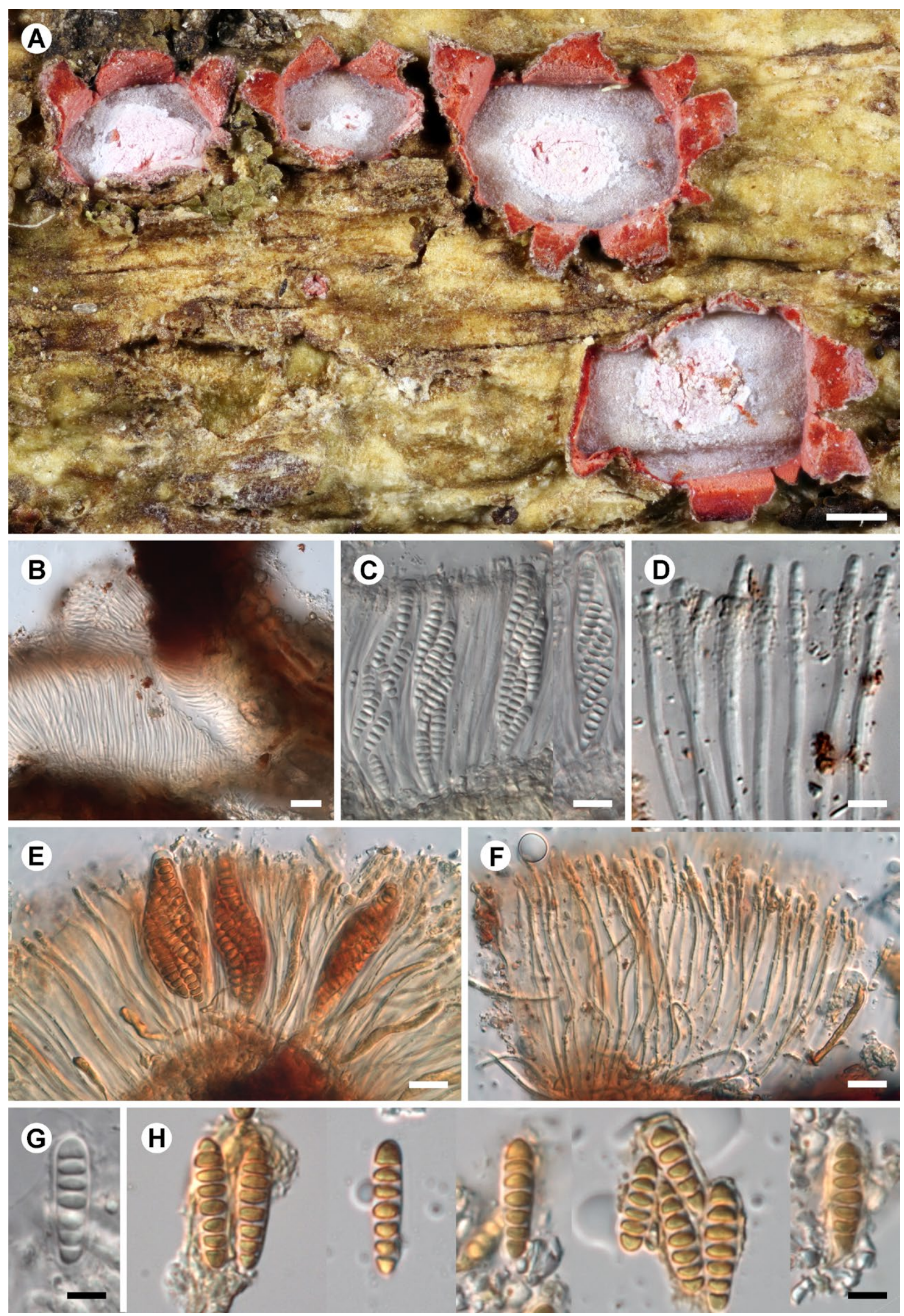

Figure 7. Chapsa alletii [holotype]. A - brownish thallus and red apothecia; B - section through apothecial margin, showing hymenium, reddish brown raised apothecial margin, and layer of periphysoids, in water; $\mathrm{C}$ - hymenium with mature 8-spored asci, in water; $\mathrm{D}$ - paraphyses apically surrounded by granules, in water; $\mathrm{E}-\mathrm{F}$ - hymenium, in Lugol; $\mathrm{G}$ - ascospore, showing halo, in water; $\mathrm{H}$ - ascospores, in Lugol. Scales: $\mathrm{A}=500 \mu \mathrm{m} ; \mathrm{B}=20 \mu \mathrm{m} ; \mathrm{C}, \mathrm{E}-\mathrm{F}=10 \mu \mathrm{m} ; \mathrm{D}, \mathrm{G}-\mathrm{H}=5 \mu \mathrm{m}$. Photos: P. Diederich. 
margin. Apart from this character, it fits the genus rather well (Frisch 2006).

It needs to be compared with genera that resemble or have recently been segregated from Chapsa. Acanthotrema A. Frisch differs by apically spinulose paraphyses and periphyses, and thin-walled ascospores (Sipman et al. 2012). Chroodiscus (Müll. Arg.) Müll. Arg. differs by thin-walled ascospores, missing periphyses, and a foliicolous habitat (Frisch 2006). The monotypic Reimnitzia Kalb differs, among others, by the brown, muriform ascospores and the thick-walled young ascospores (Frisch 2006). Gintarasia Kraichak, Lücking \& Lumbsch includes species with large apothecia up to $4 \mathrm{~mm}$ diam.; it differs from Chapsa by a more complex chemistry, and from our new species by the muriform ascospores; phylogenetically it is not related to Chapsa (Kraichak et al. 2013). Pseudochapsa Parnmen, Lücking \& Lumbsch differs by amyloid ascospores and a rarely recurved apothecial margin (Parnmen et al. 2012). Nitidochapsa Parnmen, Lücking \& Lumbsch differs by dark brown, amyloid ascospores (Parnmen et al. 2013).

In addition to Chroodiscus (see above), a few thelotrematoid genera have species with a coloured apothecial margin. Cruentotrema Rivas Plata, Papong, Lumbsch \& Lücking is distinguished by a half-carbonized upper exciple, the missing periphysoids, and apothecia with a disc hidden by a partially splitting thallus layer, which exposes a white or dark red medulla (simulating a red apothecial disc); the red pigment reacting $\mathrm{K}+$ green, almost surely identical to the pigment in our new species, has been identified by Rivas Plata et al. (2012) as isohypocrelline. Gyrotrema Frisch differs by gyrotremoid apothecia, regenerating with new hymenia and excipula formed centrifugally in concentric circles; the bright orange to cinnabar-red or pink disc reacts $\mathrm{K}+$ purple and therefore does not represent isohypocrelline (Frisch \& Kalb 2006).

A few known species with chroodiscoid apothecia have a coloured disc, such as Astrochapsa magnifica (Berk. \& Broome) Parnmen, Lücking \& Lumbsch (disc orange), A. waasii (Hale) Parnmen, Lücking \& Lumbsch (disc pink-purple, $\mathrm{K}+$ dark purple) or Chapsa rubropruinosa Messuti \& Codesal (disc red-brown, $\mathrm{K}+$ bluish), but none of them has a brightly coloured apothecial margin (Rivas Plata et al. 2010). The genus Astrochapsa Parnmen, Lücking $\&$ Lumbsch is phylogenetically distinct, 'differing from Chapsa s.str. in the more frequently densely corticate thallus, the mostly recurved apothecial margin, and the almost exclusively subdistoseptate, non-amyloid ascospores' (Parnmen et al. 2012). All these characters are shared by our new species but also by some species now included in Chapsa. Without molecular data, we are thus unable to decide if the new species is related to Chapsa s.str. or to Astrochapsa, or if it pertains to another genus owing to the distinct red pigmentation.

Etymology. The new species is dedicated to Mr Mario Allet, officer of the National Parks and Conservation Services in Mauritius and an excellent botanist, to thank him for his kindness during our 2016 and 2019 collecting trips, and for having guided us to some interesting sites, including the type locality of the new species.

\section{CHIODECTON Ach.}

*confusum Wedd. ex Nyl., Bull. Soc. Linn. Normandie, sér. 2, 7: 173 (1874 ['1873']); 三 C. confusum Wedd., in Daruty, Trans. Roy. Soc. Arts Mauritius, n.s. 7: 163 (1873), nom. nud. Original material: 'Corticola in insula Mauritii'.

\section{CHRYSOTHRIX Mont.}

candelaris (L.) J. R. Laundon [= Lepraria flava (Willd.) Ach.]. The specimens reported from Mauritius under these names (Crittenden et al. 1995; Daruty 1873; Laundon 1981) probably belong to the tropical Chrysothrix xanthina.

\section{xanthina (Vain.) Kalb}

${ }^{*}=$ Crocynia mauritiana Hue, Bull. Soc. Bot. France 71: 337 (1924). Type: 'sur un Manguier, au quartier des Pamplemousses, chez Mr Bouton', Daruty 25 (PC, holotype) (Hue 1924, Laundon 1981: 110, 2008: 412, as Chrysothrix candelaris).

Moka: Réduit, State House Park, on bark of Pinus, 2019, Diederich 18716; Réduit, close to Mauritius Herbarium, on bark of Pinus, 2019, Diederich 18698 \& Ertz 23240A; ibid., on bark, Ertz 23250. Pamplemousses: Jardin Botanique, on bark, 2016, Diederich 18254, 18594 (MAU). Rivière Noire: Chamarel, Ebony Forest, close to park buildings, on bark, 2016, Diederich 18549 (fertile).

The specimens reported from Souillac, on trunk of Casuarina equisetifolia, $14 \mathrm{~m}, 1890$, Johnston 2 (BM) by Laundon (1981: 110, as C. candelaris), and from Pamplemousses Botanical Garden, on bark of Arecaceae, 1990, Hawksworth (K-IMI) by Crittenden et al. (1995, as C. candelaris), are provisionally included here in C. xanthina.

\section{CLADIA Nyl.}

gorgonea (Eschw.) Parnmen \& Lumbsch

Plaines Wilhems: Le Pétrin, heathland NW of Pétrin Information Centre, terricolous, 2016, Diederich 18630. Without locality: Bojer (MAU L1885!, sub Cetraria aculeata).

Our recent specimen is extremely reduced but typical for this species. New for Mauritius.

\section{CLADONIA P. Browne}

balfourii Cromb. = Cladonia macilenta

\section{borbonica Nyl.}

=Cladonia fimbriata var. borbonica (Nyl.) Vain.

Reported from Mauritius, Robillard: 'in herb. Meo' by Vainio (1894: 344). Ahti (pers. comm.) saw a correctly identified specimen: Ile de France, 'Sur les vieux bois pourris, abattus dans les forêts de Pouce', c. 1840, Lepervanche-Mézières 65 (PC-Thuret).

\section{cartilaginea Müll. Arg.}

Ahti (pers. comm.) saw a specimen from Pétrin heath, 600 m, 'unter Gebüsch am Erdboden auf Holz', 1980, Schultze-Motel (B 60 0163883).

New for Mauritius.

ceratophyllina (Nyl.) Vain. [ $\equiv$ Cladonia degenerans var. ceratophyllina Nyl.]. Reported from Mauritius by Daruty (1873).

\section{confusa R. Sant.}

Plaines Wilhems: Le Pétrin, heathland NW of Pétrin Information Centre, terricolous, 2016, Diederich 18367.

Previously reported from Mauritius by Ahti \& Aptroot (1992), from Pétrin, 1967, Henderson (H) by Ruoss \& Ahti (1989), and from Pétrin, 1990, Hawksworth (K-IMI, det. Ahti) by David \& Hawksworth (1995) and Crittenden et al. (1995). Ahti (pers. comm.) saw additional specimens, both 
representing morph leptoclada: 'Native Plants Protected Forest', 1961, Fukishima (H, TNS); Pétrin, 1967, Henderson (E, H, HMAS). Further unpublished specimens from Pétrin or without accurate locality, some identified as C. alpestroides Abbayes or C. leptoclada Abbayes, are kept in CANB, O, S, UPS and WIS.

degenerans var. ceratophyllina $\mathrm{Nyl}$. $\equiv$ Cladonia ceratophyllina

didyma (Fée) Vain.

Ahti (pers. comm.) saw a specimen from Pétrin heath, 1961, Sauer 19 (S L32152).

New for Mauritius.

fimbriata (L.) Fr. Reported from Mauritius, Robillard, and from Rodrigues, 1874, Balfour (BM) by Vainio (1894: 253).

fimbriata var. borbonica (Delise) Vain. $\equiv$ Cladonia borbonica

fimbriata var. radiata (Schreb.) Cromb. Reported from Mauritius by Daruty (1873).

floerkeana (Fr.) Flörke. Reported from Mauritius by Lindau (1908).

\section{gigantea (Bory) H. Olivier}

Plaines Wilhems: Le Pétrin, heathland NW of Pétrin Information Centre, terricolous, 2016, Diederich 18607 \& Ertz 23329 (TLC of 23329: thamnolic, solvents A, B').

Previously reported from Mauritius (Les Mares and Pétrin) by Ahti (1977), and from Pétrin, 1990, Hawksworth (K-IMI, det. Ahti) by David \& Hawksworth (1995) and Crittenden et al. (1995). Further unpublished specimens from Pétrin or without locality are kept in CANB, MAU, O, PTBG and WIS.

\section{*intermediella Vain.}

Acta Soc. Fauna Fl. Fenn. 10: 12 (1894). Type: ‘Ad terram in summo monte Pouce in Mauritio', Ayres (BM - holotype, fide Ahti, pers. comm.).

The species is known also from Reunion and continental Africa (Swinscow \& Krog 1988).

\section{macilenta Hoffm.}

*= Cladonia balfourii Cromb., J. Bot. 14: 262 (1876). Type: Rodrigues, on dead (rotten) stumps of trees, 1874, Balfour 2204 (BM, lectotype, designated by Ahti 2000; E, FHDodge, H-NYL 39124, UPS, isolectotypes).

Previously reported from Mauritius by Daruty (1873) and Lindau (1908). Further unpublished specimens from Curepipe Botanical Garden, Mt Cocotte and Pétrin, collected by Krog \& Timdal in 1991, are kept in O.

macilenta var. polydactyla (Flörke) $\equiv$ Cladonia polydactyla

\section{*mauritiana Ahti \& J. C. David}

in David \& Hawksworth, Biblioth. Lichenol. 57: 94 (1995). Type: Mauritius, Black River, east of Chamarel, alt. 300 m, on soil by road, 16 June 1990, Hawksworth (K-IMI 400678 holotype, $\mathrm{H}$ - isotype).

Plaines Wilhems: Le Pétrin, heathland NW of Pétrin Information Centre, terricolous, 2016, Diederich 18371; ibid., 2019, Ertz 23330, 23337, 23348 (TLC: fumarprotocetraric, solvents A, B'); Curepipe, Curepipe Botanic Gardens, over mosses, at the base of a tree, 2016, Diederich 18314.

A further unpublished specimen from Pétrin, Schultze-Motel (B) was studied by Ahti (pers. comm.). The species has also been reported from Reunion, Comoro Is., Seychelles, India, Malaysia and Thailand (Ahti et al. 2002).

\section{medusina (Bory) Nyl.}

= Cladonia medusina var. dealbata Vain.; = Cladonia medusina var. luteola (Bory) Vain.

Plaines Wilhems: Le Pétrin, heathland NW of Pétrin Information Centre, terricolous, 2016, Diederich 18366. Savanne: Road from Le Pétrin to Chamouny, beginning of trail to Montagne Cocotte, on dead wood, 2016, Diederich 18379.

Previously reported from Mauritius by Hue (1898) and Vainio (1887: 242-243, as var. dealbata and var. luteola), and from Pétrin, 1990, Hawksworth (K-IMI, det. Ahti) by David \& Hawksworth (1995) and Crittenden et al. (1995). Further unpublished specimens from Pétrin are kept in MAU, O, PTBG, US and WIS.

pityrea var. subareolata Vain. Reported from Mauritius by Vainio (1894).

polydactyla (Flörke) Spreng. Reported from Mauritius by Daruty (1873, as 'C. macilenta var. polydactyla Flk.').

pycnoclada (Pers.) Nyl. The report from Mauritius, Bojer, by Vainio (1887: 38) obviously refers to C. confusa.

rangiferina (L.) Weber ex F. H. Wigg. The report from Mauritius, 1825, Despreaux (PC) by Vainio (1887: 13) obviously refers to $C$. gigantea.

squamosa (Scop.) Hoffm. Reported from Mauritius, Gardner? by Vainio (1887: 417)

uncialis (L.) Weber ex F. H. Wigg. The report from Mauritius by Daruty (1873) may refer to specimen Bojer 14 (MAU L189!, sub Cladonia uncialis), which is an unidentified Cladia.

\section{varians Vain. ex Ahti}

$\left(^{*}\right)=$ Cladonia varians var. glaucoflava Vain., in Hue, Lichenes extra-europaei: 267 (1898), nom. inval. Original material: three specimens were mentioned in the original publication from Reunion, Mauritius (1890) and Madagascar, all leg. fr. Rodriguez.

$\left({ }^{*}\right)=$ Cladonia varians var. erythrospermoides Vain., in Hue, Lichenes extra-europaei: 267 (1898), nom. inval. Original material: two specimens were mentioned in the original publication from Reunion and Mauritius (1890 and 1891), both leg. fr. Rodriguez.

Following Ahti et al. (1987: 94), 'Vainio (in Hue 1898) reported C. varians from Reunion, Mauritius and Madagascar, and the author Ahti has confirmed his identifications (in PC and TUR-V)'. The PC online database, consulted on 17 Febr. 2019, contains a specimen from Reunion and one from Madagascar, but no specimen from Mauritius. The report by Swinscow \& Krog (1988) from Rodrigues appears to be based on confusion with the name of the collector of the type material, fr. Rodriguez (Ahti \& Aptroot 1992).

\section{COCCOCARPIA Pers.}

*adnata L. Arvidss.

Opera Bot. 67: 42 (1982). Type: Plaine Champagne, 20 km $\mathrm{S}$ of Rose Hill, $700 \mathrm{~m}$, on trunks of a small tree in submontane scrub, 14 April 1979, Arvidsson \& Nilsson 2660 (GB 0128129 - holotype).

A species widely distributed in the Paleotropics (Arvidsson 1982). 
erythroxyli (Sprengel) Swinscow \& Krog

${ }^{*}=$ Peltidea floerkeana Laurer, Linnaea 2: 43 (1827). Type: 'In insula St. Mauritii' (type of Peltidea floerkeana not traced, probably destroyed; Laurer 1827, tab. I, fig. 3, lectotype, designated by Arvidsson 1982: 57).

= Coccocarpia molybdaea Pers.

Reported from Mauritius by Daruty (1873), from 4 specimens (GB, PC) by Arvidsson (1982: 62), from Ile aux Aigrettes (BM, det. James) by Parnell et al. (1989), and from Rodrigues, on branches of trees, 1874, Balfour 2243 by Crombie (1876b). Further unpublished specimens from Morne du Grand Port and Ile aux Aigrettes are kept in MAU and O.

molybdea Pers. $=$ Coccocarpia erythroxyli

palmicola (Sprengel) Arv. \& D. J. Galloway

Plaines Wilhems: Curepipe Botanic Gardens, on bark, 2019, Diederich 19111, 19189 \& Ertz 24132. Rivière Noire: Chamarel, Ebony Forest, around viewpoint, on bark, 2016, Diederich 18528, 18529; ibid., on termite nest, 2019, Ertz 23563; ibid., along trail W of viewpoint, on bark, 2019 , Diederich 19405.

Previously reported from Mauritius (GB, 12 specimens) by Arvidsson (1982: 76), from Ile aux Aigrettes (BM, det. James) by Parnell et al. (1989), from Savanne, Plaines Champagne, at viewpoint of Black River Gorge, 1990, Hawksworth (K-IMI) by Crittenden et al. (1995), and from Grand Port, Bambou Mountains, 1991, Krog \& Timdal (O) by Lücking \& Timdal (2016). Further unpublished specimens from Curepipe (Trou aux Cerfs, Botanical Garden), Black River (La Mivoie), Grand Port (Ile aux Aigrettes), Pétrin, Macchabee Kiosk and Mt Cocotte, collected by Krog \& Timdal in 1991, are kept in O.

pellita (Ach.) Müll. Arg.

Plaines Wilhems: Curepipe, Trou aux Cerfs, along road surrounding the crater, on bark, 2016, Diederich 18282; Le Pétrin, between Pétrin Information Centre and first viewpoint along trail to the west, on bark, 2016, Diederich 18318, 18335. Rivière Noire: E of Black River, from Visitor's Centre to Pilgrims Trail, on bark, 2016, Diederich 18483, 18484; Trail from Plaine Champagne towards Piton de la Petite Rivière Noire, on bark, 2016, Diederich 18614, 18615; Brise Fer Forest, on bark, 2019, Diederich 19218.

Previously reported from Mauritius by Lindau (1908) and from one specimen in GB by Arvidsson (1982: 79). Further unpublished specimens from Pétrin, Macchabee Forest, Trou aux Cerfs and Mt Cocotte, collected by Krog \& Timdal in 1991, are kept in O.

\section{pruinosa Arv.}

Reported from Grand Port, Mt des Créoles, 1991, Krog \& Timdal (O) by Lücking \& Timdal (2016: 198). Further unpublished specimens from Mt Cocotte, Piton de la Petite Rivière Noire and Macchabee Forest, collected by Krog \& Timdal in 1991, are kept in O.

\section{smaragdina Pers.}

Plaines Wilhems: Curepipe Botanic Gardens, on bark, 2019, Diederich 19109 \& Ertz 24250. Rivière Noire: Trail from Plaine Champagne towards Piton de la Petite Rivière Noire, on bark, 2016, Diederich 18612, 18613. Port Louis and Moka: Along trail from Moka to Le Pouce, on rock, 2019, Ertz 24082. Savanne: Along trail to Mt Cocotte, on bark, 2019, Diederich 18858, 18867 \& Ertz 23515.
Previously reported from Mauritius, 1876, Robillard (G) by Arvidsson (1982: 86), by Crittenden et al. (1995), and from Grand Port, Mt des Créoles, 1991, Krog \& Timdal (O) by Lücking \& Timdal (2016: 198). Further unpublished specimens from Mt Cocotte, Piton de la Petite Rivière Noire and Curepipe Botanical Garden, collected by Krog \& Timdal in 1991, are kept in O.

\section{stellata Tuck.}

Reported from Plaine Champagne, $20 \mathrm{~km} \mathrm{~S}$ of Rose Hill, 1979, Arvidsson \& Nilsson 2659 (GB) by Arvidsson (1982: 89).

\section{COENOGONIUM Ehrenb.}

leprieurii (Mont.) Nyl. Reported from Mauritius by Hue (1892: 181).

\section{COLLEMA Weber ex F. H. Wigg.}

azureum (Sw.) Ach. $\equiv$ Leptogium azureum (Sw.) Mont.

burgessii (L.) Ach. $\equiv$ Leptogium burgessii

byrsinum Ach. $\equiv$ Physma byrsinum

*coilocarpum (Müll. Arg.) Zahlbr.

Cat. Lich. Univ. 3: 34 (1924 ['1925’]); 三 Synechoblastus coilocarpus Müll. Arg., Lichenol. Beitr. 34, Flora 74 (1891): 107. Type: 'Corticola in insula Mauritii, Dr Cupes, L[ouis] B[outon] n. 1580' (G 00066537, lectotype; K, isolectotype) (Degelius 1974: 145).

leptaleum var. biliosum (Mont.) Degel. Reported from Mauritius by Crittenden et al. (1995)

\section{leptaleum Tuck. var. leptaleum}

*=? Synechoblastus robillardii Müll. Arg., Lichenol. Beitr. 6, Flora 60: 471 (1877); 三 Collema robillardii (Müll. Arg.) Stizenb., Lichenaea afric. 1, Ber. Thätigk. St. Gallischen Naturwiss. Ges. 1888-89: 119 (1890), nom. conf. Type: Mauritius, 'corticola', 1876, Robillard (G 00066251, lectotype; G 00066252, TUR-Vainio 11453, US, isolectotypes; FH 00302074 [not examined by Degelius, but probably part of the type specimen], isolectotype?).

Following Degelius (1974), the lectotype (G) and the isolectotype (US) of S. robillardii are a mixture of Collema leptaleum var. leptaleum and C. cf. pulcellum var. subnigrescens. A specimen in TUR evidently belongs to the type collection and represents C. leptaleum var. leptaleum. Also reported from Pouce, Bojer (K), and Pouce, 1860, Cupes (K) (Degelius 1974: 108).

nigrescens (Huds.) DC. Reported from Mauritius by Daruty (1873).

robillardii (Müll. Arg.) Stizenb. =? Collema leptaleum var. leptaleum

\section{rugosum Kremp.}

Moka: Réduit, State House Park, on bark of Cinnamomum, 2019, Diederich 19312. Pamplemousses: 1 km NNW of Botanical Garden, S of Museum 'Aventure du sucre', on bark, 2016, Diederich 18624; Jardin Botanique, on bark, 2016, Diederich 18232 \& Ertz 21501. Plaines Wilhems: Curepipe Botanic Gardens, on bark, 2019, Diederich 19201 \& Ertz 24225. Rivière Noire: East of Black River, from Visitor's Centre to Pilgrims Trail, on bark, 2016, Diederich 18477, 18480; Chamarel, Ebony Forest, around viewpoint, on bark, 
2016, Diederich 18556; Le Morne Peninsula, S coast, on bark, 2019, Diederich 19443.

Previously reported from Pamplemousses Botanical Garden, on a tree, 1990, Hawksworth (K-IMI) by David \& Hawksworth (1995), and from Moka, below Mt Ory, on a tree, 1990, Hawksworth (K-IMI) by David \& Hawksworth (1995) and Crittenden et al. (1995).

\section{subflaccidum Degel.}

Reported from Moka, below Mt Ory, on shaded volcanic rocks, 1990, Hawksworth (K-IMI) by David \& Hawksworth (1995) and Crittenden et al. (1995). A further unpublished specimen, collected in Pamplemousses Botanical Garden in 1997 by Jørgensen, is kept in BG.

\section{COLLEMOPSIDIUM Nyl.}

Collemopsidium mauritiae Diederich \& Ertz, sp. nov. (Fig. 8)

\section{MycoBank MB 834922}

Diagnosis: Distinguished by a thallus initially formed by goniocysts, eventually developing into flat areoles, a bluish green cyanobacterial photobiont, black perithecia, 100$180 \mu \mathrm{m}$ diam., without involucrellum, anastomosed paraphysoids, 8 -spored asci, $52-55 \times 13-17 \mu \mathrm{m}$, and 1-septate, hyaline ascospores, 13-15 $\times 5.5-6.5 \mu \mathrm{m}$.

Type: Mauritius, Rivière Noire, La Preneuse (between Tamarin and Grande Rivière Noire), cemetery (SE part with old graves), $20.3589^{\circ} \mathrm{S}, 57.3671^{\circ} \mathrm{E}$, alt. $10 \mathrm{~m}$, on old tombstones from c. 1850, 4 Aug. 2016, Diederich 18672 (MAU - holotype, herb. Diederich - isotype).

Description. Thallus epilithic, calcicolous, crustose, greenish black to black, forming colonies up to $\sim 5 \mathrm{~cm}$ diam.; when young, composed of isolate goniocysts $25-50 \mu \mathrm{m}$ diam. that become larger with age, then develop into flat, angular areoles, $200-400 \mu \mathrm{m}$ diam., 20-70 $\mu \mathrm{m}$ thick (when dry), bearing marginal goniocysts as vegetative diaspores; surface of mature colonies appearing as rimose to areolate (cracks closing when thallus is wetted), matte, \pm smooth to minutely uneven. Hyphal layer around goniocysts brownish when exposed, 3.5-7 $\mu \mathrm{m}$ thick. Photobiont cyanobacterial, bluish-green, ellipsoid, 2-4-celled, $8-14 \times 6.5-11 \mu \mathrm{m}$, wall 1-2 $\mu \mathrm{m}$ thick; groups of cyanobacteria surrounded by a gelatinous sheath. Prothallus and basal layer not apparent. Ascomata perithecioid, solitary, subspherical, semi-immersed to almost superficial, slightly rough and matte, black, 100-180 $\mu \mathrm{m}$ diam. Ostiole sometimes depressed, 20-60 $\mu \mathrm{m}$ wide when dry. Involucrellum absent. Excipulum entirely dark brown to black, 25-35 $\mu \mathrm{m}$ thick; cells rather indistinct, $\sim 6-11 \mu \mathrm{m}$ diam. Hymenial gel I-. Paraphysoids anastomosing, 1-2 $\mu \mathrm{m}$ thick. Periphysoids not observed. Asci fissitunicate, broadly ellipsoid, 8-spored, $52-55 \times 13-17 \mu \mathrm{m}$, at first with a broad and elongate, beak-like ocular chamber that becomes shorter and comparatively broad at maturity; ascoplasma I+ orange-red; wall I-, laterally $2-3 \mu \mathrm{m}$, apically $2.5-6 \mu \mathrm{m}$ thick. Ascospores hyaline, 1 -septate, slightly constricted at the septum, the upper cell slightly broader and distinctly shorter than the lower cell, 13-15 $\times 5.5-6.5 \mu \mathrm{m}$, with a distinct hyaline perispore, $1-1.5(-2) \mu \mathrm{m}$ thick in water. Pycnidia not observed.

Ecology and distribution. On calcareous rock (mortar) in a historic cemetery, known only from the type locality in Mauritius.
Notes. The genus Collemopsidium includes more than ten species worldwide (some of which formerly treated within Pyrenocollema) (Grube \& Ryan 2002). Several of these are confined to marine habitats (Mohr et al. 2004), others to rocks submerged in freshwater, and a few on sand or rocks in humid conditions. Many of these are described and keyed out by Coppins \& Orange (2009). Amongst the saxicolous, non-marine British species treated by those authors, C. angermannicum is distinguished by the ecology (siliceous rocks beside rivers and lakes) and the larger ascospores, 17-26 × 6-12 $\mu \mathrm{m}$. Both C. caesium and C. monense are as well distinguished by larger ascospores, 20-30(-33) $\times(7.5-) 8.5-12 \mu \mathrm{m}$, resp. 17-30(35) × 6-8 $\mu \mathrm{m}$. The four non-marine, mainly American species of Pyrenocollema keyed out by Harris (1995) most differ by having larger ascospores; $P$. atlanticum has only slightly larger ascospores but clearly differs by a yellow-brown to brown photobiont. C. montanum differs by much larger ascospores, $28-58 \times$ 11-21 $\mu \mathrm{m}$, and larger ascomata, 220-500 $\mu \mathrm{m}$ diam., with a distinct involucrellum (McCarthy \& Kantvilas 1999). C. heardense (Øvstedal \& Gremmen 2010) is distinguished by much larger ascospores, $23-25 \times 11-13 \mu \mathrm{m}$. C. chlorococcum is the only known species from the genus with green algae and further differs by not being saxicolous (Aptroot $\&$ van den Boom 1998). C. japonicum differs by a purplish brown, continuous thallus and larger ascospores, 15-21 $\times$ 6-8 $\mu \mathrm{m}$ (Harada 1999).

Etymology. The epithet denotes the country Mauritius (Latin: Mauritia), where the new species was discovered.

Additional specimen examined. MAURITIUS. Same locality as type, 2019, Ertz 23238; Flic-en-Flac, cemetery, on historic tombs, 2019, Diederich 19084 (MAU).

CONSTRICTOLUMINA Lücking, M. P. Nelsen \& Aptroot planorbis (Ach.) Lücking, M. P. Nelsen \& Aptroot [三 Verrucaria planorbis Ach.]. 'Sur l'écorce des Rubiacées arborescentes, à l'île Maurice' (Bélanger 1834).

\section{CORA Fr.}

(*)gyrolophia Fr., Epicr. Syst. Mycol. (Upsaliae): 556 (1838). Type: Mauritius, Sieber 65 (S L2148, lectotype, selected by Lücking et al. 2015a; HAL 3024F, isolectotype); Sieber 59 (S L39459, paratype).

$\left(^{*}\right)=$ Gyrolophia elegans Kunze, in Von Krombholz, Naturgetr. Abbild. Beschr. Schwämme (Prague) 1: 76, tab. 5, fig. 16 (1831), nom. inval.

$\left(^{*}\right)=$ Gyrolophia mauritianum Kunze, in Index Fungorum, nom. inval.

Sieber visited Mauritius during a circumnavigation from 1822 to 1824 , where he collected numerous plant specimens (https://de.wikipedia.org/wiki/Franz_Wilhelm_Sieber). Nevertheless, it might be that these Cora specimens were not collected by him. He received many lichen specimens from the Antilles (leg. Kohaut) and from Mauritius (leg. Bojer). Possibly he obtained the Cora specimens from the Antilles but mislabelled them as 'Mauritius'. This suggestion is supported by the statement on Wikipedia (https://en.wikipedia.org/wiki/Franz_Sieber), following which Sieber's 'behaviour and publications became progressively more erratic. He ... became more and more deranged'. As the genus Cora is more or less confined to the Neotropics, with the exception of two species known from the South Atlantic islands Trindade and Saint Helena (Lücking et al. 2015a) and one described from Sri Lanka (Lücking et al. 2017b), 

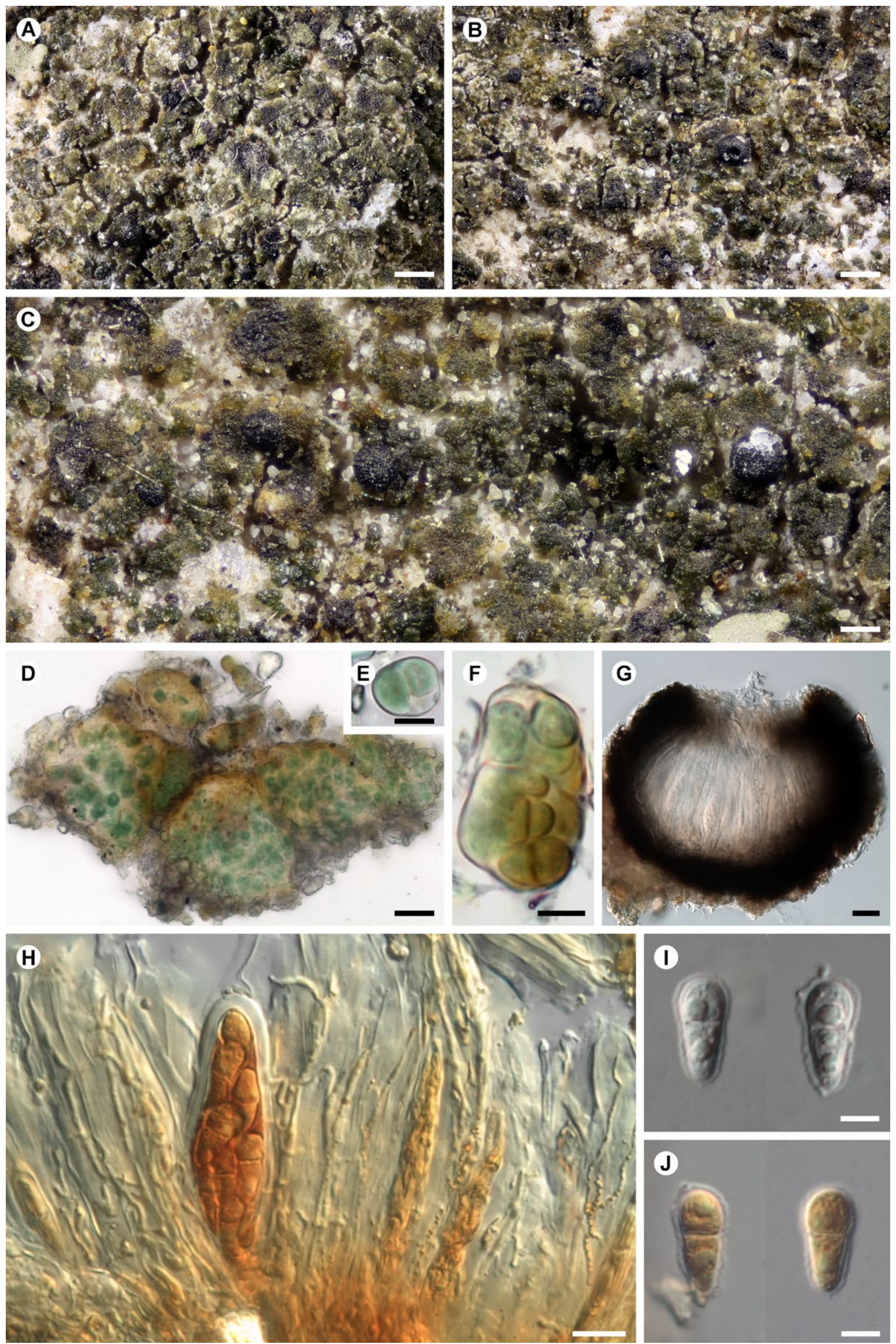

Figure 8. Collemopsidium mauritiae [holotype]. A - areolate thallus; B - thallus with two perithecia; $\mathrm{C}$ - thallus with areoles (above), abundant goniocysts (below) and perithecia; D - thallus developing goniocysts, in water; E - cyanobacterium, in water; F - group of cyanobacteria surrounded by a gelatinous sheath, in water; $\mathrm{G}$ - section through perithecium, in water; $\mathrm{H}$ - hymenium, showing ascus with ascospores, and paraphysoids, in Lugol; I - ascospores, showing perispore, in water; $\mathrm{J}$ - ascospores, in Lugol. Scales: A-B $=200 \mu \mathrm{m} ; \mathrm{C}=100 \mu \mathrm{m} ; \mathrm{D}, \mathrm{G}=20 \mu \mathrm{m} ; \mathrm{H}=10 \mu \mathrm{m}$; E-F, I-J $=5 \mu \mathrm{m}$. Photos: P. Diederich. 
we prefer therefore to provisionally consider the presence of Cora gyrolophia in Mauritius as dubious, awaiting the discovery of further populations of this species either in the Antilles or in Mauritius.

\section{CORNUTISPORA Piroz.}

lichenicola D. Hawksw. \& B. Sutton $\equiv$ Spirographa lichenicola

\section{CROCODIA Link}

\section{aurata (Ach.) Link}

$\equiv$ Pseudocyphellaria aurata (Ach.) Vain.; ESticta aurata Ach.

Plaines Wilhems: Curepipe, Trou aux Cerfs, along road surrounding the crater, on bark, 2016, Diederich 18284 (dupl. LG); ibid., 2019, Diederich 19203; Le Pétrin, between Pétrin Information Centre and first viewpoint along trail to the west, on bark, 2016, Diederich 18317 (MAU). Rivière Noire: Trail from Plaine Champagne towards Piton de la Petite Rivière Noire, on bark, 2016, Diederich 18465 (MAU); Chamarel, Ebony Forest, around viewpoint, on bark, 2016, Diederich 18527. Savanne: Along trail to Mt Cocotte, on bark, 2019, Diederich 19547 (MAU).

Previously reported from Mauritius by Laurer (1827), Søchting 30A12 (C) by Moncada et al. (2014: 122), from Pétrin heath, Pétrin Rainforest and Le Pouce, 600 m, 2001, by Holm \& Gregersen (2002), from Macchabee Forest, 1990, Hawksworth (K-IMI) by David \& Hawksworth (1995) and Crittenden et al. (1995), and from Rodrigues, on trunks of trees, 1874, Balfour 2273 (BM) by Crombie (1876b) and Galloway (1994: 119). Further unpublished specimens, collected in Mt Corps de Garde and Mt Cocotte by Krog \& Timdal in 1991, are kept in O.

CROCYNIA (Ach.) A. Massal.

gossypina (Sw.) A. Massal. $\equiv$ Phyllopsora gossypina (Sw.) Kistenich, Timdal, Bendiksby \& S. Ekman

mauritiana Hue $=$ Chrysothrix xanthina

molliuscula (Nyl.) Nyl., see under Phyllopsora

CYANISTICTA Gyeln.

argyracea (Delise) Gyeln. $\equiv$ Pseudocyphellaria argyracea

aurigera (Bory) Dodge $=$ Pseudocyphellaria crocata

mougeotiana $($ Delise) Dodge $=$ Pseudocyphellaria crocata

\section{CYPHELLOSTEREUM D. A. Reid}

\section{*bicolor Lücking \& Timdal}

Willdenowia 46: 192 (2016). Type: Grand Port, Bambou Mountains, $0.5-1 \mathrm{~km}$ NNE of Piton Rouge, on tree bark, 12 Nov. 1991, Krog \& Timdal MAU36/02 (O L-21699 holotype, F - isotype) (Lücking \& Timdal 2016).

\section{DENDRISCOSTICTA B. Moncada \& Lücking}

platyphylla (Trevis.) B. Moncada \& Lücking [三Lobaria platyphylla Trevis.; E Sticta damicornis var. platyphylla $;=$ Sticta nylanderiana Zahlbr.; $\equiv$ Stictina nylanderiana (Zahlbr.) Dodge]. This species was reported from Mauritius by Dodge (1964: 185). Specimens from Mauritius kept in S (Sieber, S F159142; 'n. 38 Sieber II cypt. exot. Herb. Erik P. Vrang', S F158916; 'Pl. crypt. exot. 38, herb. Erik P. Vrang', S F159140, S F159141) and UPS ('ad cortice arborum, Hilsenberg, Trevisan, Lichenoth. Ven. Nr. 77, Crypt. exot. exs. n. 38', UPS L696223) need to be revised.

\section{DIBAEIS Clem.}

\section{holstii (Müll. Arg.) Kalb \& Gierl}

Reported from S of Curepipe, Trou Raoul Crater, on soil, 1990, Hawksworth (K-IMI) by David \& Hawksworth (1995) and Crittenden et al. (1995).

\section{DICTYONEMA C. Agardh ex Kunth}

*album Lücking \& Timdal

Willdenowia 46: 192 (2016). Type: Savanne, Plaine Champagne, near viewpoint WNW of Mt Cocotte, 18 Nov. 1991, Krog \& Timdal MAU57/04 (O L-21992 - holotype, F, MAU 21886, isotypes) (Lücking \& Timdal 2016).

Also reported from the road between Mt Cocotte and Bassin Blanc, 1991, Krog \& Timdal (O) (Lücking \& Timdal 2016).

coppinsii Lücking, Barrie \& Genney

Reported from Grand Port, Mt des Créoles, 1991, Krog \& Timdal (F, O) by Lücking \& Timdal (2016: 198).

\section{DIORYGMA Eschw.}

\section{hieroglyphicum (Pers.) Staiger \& Kalb}

Pamplemousses: Jardin Botanique, on bark of Brownea grandiflora, 2016, Ertz 21445. Port Louis and Moka: Along trail from Moka to Le Pouce, on bark, 2019, Ertz 24052 (TLC: stictic, solvents A, B'), 24084 (TLC: stictic, unknown brownish of $\mathrm{Rf} \pm 20$, trace of norstictic, solvents $\left.A, B^{\prime}\right)$.

New for Mauritius.

poitaei (Fée) Kalb, Staiger \& Elix [三 Opegrapha poitaei (Fée) Bél.]. 'Sur l'écorce des arbres, à l'île Maurice' (Bélanger 1834).

\section{DIPLOSCHISTES Norman}

scruposus (Schreb.) Norman

Plaines Wilhems: Le Pétrin, heathland NW of Pétrin Information Centre, on lava rocks, 2016, Diederich 18363; ibid., 2019, Diederich 19346. Savanne: Road from Le Pétrin to Chamouny, beginning of trail to Montagne Cocotte, on rocks along a stream, 2016, Diederich 18380.

New for Mauritius.

\section{DIRINA Fr.}

*astridae Tehler

in Tehler et al., Lichenologist 45: 444 (2013). Type: Port Louis Distr., Port Louis, Mt Signal, on the peak $\sim 200 \mathrm{~m} \mathrm{E}$ of the tele station, 2003, Tehler 8502 (S L55012, holotype; BR 5030024434876, isotype); ibid., Tehler 8503 (S L55013).

Further reported from the western part of Mauritius (Tehler \& Irestedt 2007, as Dirina paradoxa subsp. africana), from Black River, Mt St. Pierre, the eastern peak near Bambous, $\sim 7 \mathrm{~km}$ E Quatre Bornes, 2003, Tehler (S) (Tehler et al. 2010, 2013; Frisch et al. 2014), and from Savanne, Maconde on south coast, $\sim 500 \mathrm{~m} \mathrm{~W}$ of Baie du Cap, 2003, Tehler (S) (Tehler et al. 2013).

monothalamia Tehler \& Ertz. The Mauritius material published under this name by Frisch et al. (2014) belongs to Dirina astridae Tehler (Tehler et al. 2013).

paradoxa subsp. africana (Fée) Tehler. The Mauritius material published under this name by Tehler \& Irestedt (2007) belongs to Dirina astridae Tehler (Tehler et al. 2013). 


\section{DIRINARIA (Tuck.) Clem.}

aegialita (Afzel. ex Ach.) B. J. Moore

$\equiv$ Physcia aegialita (Afzel. ex Ach.) Nyl.

Moka: Réduit, State House Park, on bark of Pinus, 2019, Diederich 19318; Réduit, close to Mauritius Herbarium building, on bark of Mangifera, 2019, Diederich 18690; ibid., on bark of Pinus, Diederich 18693. Plaines Wilhems: Curepipe, Curepipe Botanic Gardens, on bark, 2016, Diederich 18304; ibid., on bark of palm trees, 2019, Diederich 19095 \& Ertz 24206 (TLC of 24206: atranorin, divaricatic, unknown terpenes, solvents A, B'). Rivière Noire: Trail from Plaine Champagne towards Piton de la Petite Rivière Noire, on bark, 2019, Ertz 24009 (TLC: atranorin, divaricatic, unknown terpenes, solvents A, B').

Previously reported from Nicolière Mountains, Nouvelle Découverte, on volcanic rocks, 1990, Hawksworth (K-IMI) by David \& Hawksworth (1995) and Crittenden et al. (1995), and from Rodrigues, on rocks, 1874, Balfour 2225 by Crombie (1876b). A further unpublished specimen, collected in Réduit near the Mauritius Herbarium by Krog \& Timdal in 1991, is kept in O.

\section{applanata (Fee) D. D. Awasthi}

Moka: Réduit, State House Park, on bark of Cinnamomum, 2019, Diederich 19313; ibid., on bark of Pinus, 2019, Diederich 19319. Pamplemousses: $1 \mathrm{~km}$ NNW of Botanical Garden, S of Museum 'Aventure du sucre', on bark, 2016, Diederich 18622. Rivière Noire: La Preneuse (between Tamarin and Grande Rivière Noire), cemetery (SE part with old graves), on bark at the base of a tree, 2016, Diederich 18386; Chamarel, Ebony Forest, around viewpoint, on exposed rocks, 2019, Diederich 18916.

Previously reported from Mauritius by Crittenden et al. (1995), from centre de Flacq, on Ficus, 1990, Hawksworth (K-IMI) by David \& Hawksworth (1995), and from Pamplemousses Botanical Garden, on Hyophorbe amaricaulis, 1990, Hawksworth (K-IMI) by David \& Hawksworth (1995).

picta (Sw.) Schaer. ex Clem.

$\equiv$ Physcia picta (Sw.) Nyl.

Moka: Réduit, State House Park, on bark, 2019, Diederich 19290; Réduit, close to Mauritius Herbarium building, on bark of Pinus, 2019, Diederich 18686. Pamplemousses: Jardin Botanique, on bark, 2016, Diederich 18240, 18268, 18591. Rivière Noire: Chamarel, Ebony Forest, around viewpoint, on exposed rocks, 2019, Diederich 19390.

Previously reported from Mauritius by Lindau (1908), from Round Island, on W side of the island by Johnston (1894: 263), from Ile aux Aigrettes by Parnell et al. (1989) (BM, det. James), and from Rodrigues, on branches of trees, 1874, Balfour 2373 by Crombie (1876b).

DYPLOLABIA A. Massal.

afzelii (Ach.) A. Massal. [三 Graphis afzelii Ach.]. Reported from Mauritius by Daruty (1873) and Crittenden et al. (1995).

\section{ENDOCARPON Hedw.}

\section{*johnstonii (Müll. Arg.) Stizenb.}

Ber. Thätigk. St. Gallischen Naturwiss. Ges. 1893-94: 259 (1895); 三 Paracarpidium johnstonii Müll. Arg., Hedwigia 31: 286 (1892). Type: Ile aux Fouquets, Mauritius, 'vulgaris ad saxa sabulosa, $\sim 5-35$ ped. supra mare', Johnston (G 00291830 - holotype, BM - isotype).

\section{ERIODERMA Fée}

sorediatum D. J. Galloway \& P. M. Jørg.

Reported from Piton de la Petite Rivière Noire by Timdal (2002: 296), and from the entrance to Macchabee Forest, on bark, 1990, Hawksworth (K-IMI) by David \& Hawksworth (1995) and Crittenden et al. (1995). Further unpublished specimens from Plaine Champagne towards Piton de la Petite Rivière Noire and Mt Cocotte, collected by Krog \& Timdal in 1991, are kept in O.

\section{ETAYOA Ertz \& Diederich}

+trypethelii (Flakus \& Kukwa) Diederich \& Ertz

Plaines Wilhems: Curepipe, Trou aux Cerfs, along road surrounding the crater, on bark, on Phaeographis, 2016, Diederich 18275 (sub Phaeographis sp.); Le Pétrin, between Pétrin Information Centre and first viewpoint along trail to the west, on bark, on Allographa calcea, 2016, Diederich 18352 (sub A. calcea); Le Pétrin, heathland NW of Pétrin Information Centre, on bark, on Graphidaceae, 2019, Diederich 19365.

This lichenicolous fungus is rather common in tropical and subtropical countries, where it can be found on corticolous, crustose lichens belonging to different phylogenetic groups, being particularly frequent on members of Graphidales (Ertz et al. 2014). New for Mauritius.

\section{FLAVOPARMELIA Hale}

caperata $($ L.) Hale [三 Parmelia caperata (L.) Ach.]. Reported from Mauritius by Daruty (1873), and 'Sur les arbres, à l'île Maurice' by Bélanger (1834) (PC 0018177).

\section{GIBBOSPORINA Elvebakk, S. G. Hong} \& P. M. Jørg.

didyma Elvebakk, Hong \& P. M. Jørg.

Reported from Piton de la Petite Rivière Noire, 1991, Krog \& Timdal (O) by Elvebakk et al. (2016: 32).

mascarena Elvebakk, Hong \& P. M. Jørg.

Rivière Noire: Trail from Plaine Champagne towards Piton de la Petite Rivière Noire, on bark, 2016, Diederich 18399 (dupl. LG); ibid., 2019, Ertz 23915, 23954. Savanne: Along trail to Mt Cocotte, on bark, 2019, Diederich 18846.

Previously reported from the same two localities and from Macchabee Forest, 1991, Krog \& Timdal (O) by Elvebakk et al. (2016: 35).

GLOMERULOPHORON Frisch, Ertz \& G. Thor

${ }^{*}$ mauritiae Frisch, Ertz \& G. Thor

in Frisch et al., Lichenologist 47: 252 (2015). Type: Mauritius, Pamplemousses, Botanical Garden, parc, sur tronc, 18 Febr. 2014, Ertz 19164 (BR - holotype, MAU - isotype).

Moka: Réduit, State House Park, on bark, 2019, Diederich 18731, 18738; Réduit, close to Mauritius Herbarium, on bark, 2019, Diederich 18695. Pamplemousses: Same locality as type, on bark, 2016, Diederich 18261. Rivière Noire: Chamarel, Ebony Forest, along trail W of viewpoint, 
on bark, 2019, Diederich 19447; Le Morne Peninsula, S coast, on bark, 2019, Diederich 19254 \& Ertz 24268.

Currently known from Mauritius and Seychelles (Diederich et al. 2017).

\section{GLYPHIS Ach}

cicatricosa Ach.

= G. cicatricosa var. favulosa (Ach.) Nyl.; = G. cribrosa Fée

Moka: Réduit, State House Park, on bark, 2019, Diederich 19286; ibid., on bark of Terminalia angustifolia, 2019, Diederich 19292. Pamplemousses: Jardin Botanique, on bark of Verschaffeltia splendens, 2016, Ertz 21433; ibid., on bark of Agathis, Ertz 21467. Plaines Wilhems: Plaisance, Rose Hill, sur un Jam Rosadier (Syzygium jambos), s. d. (probably 1873 or 1874), Daruty 63 (MAU L1995!, sub Verrucaria nitida); Curepipe Botanic Gardens, on bark, 2019, Diederich 19137, 19167 \& Ertz 24182; Le Pétrin, along trail W of Pétrin Information Centre, up to $600 \mathrm{~m} \mathrm{~W}$ of first viewpoint, on bark, 2019, Diederich 18779 \& Ertz 23445. Rivière Noire: East of Black River, from Visitor's Centre to Pilgrims Trail, on bark, 2016, Diederich 18505.

Reported from Mauritius by Daruty (1873, as G. cicatricosa and $G$. cribrosa), and from Rodrigues, on branches of trees, 1874, Balfour 2295 by Crombie (1876b, as G. cicatricosa var. favulosa).

cicatricosa var. favulosa (Ach.) Nyl. = Glyphis cicatricosa

cribrosa Fée $=$ Glyphis cicatricosa

scyphulifera (Ach.) Staiger

Moka: Réduit, State House Park, on bark of Phyllanthus emblica, 2019, Diederich 19296. Pamplemousses: Jardin Botanique, on bark of Dypsis lutescens, 2016, Ertz 21439. New for Mauritius.

tricosula Nyl. ex Cromb. $\equiv$ Sarcographa tricosula

\section{GRAPHIS Adans.}

aequabilis Wedd. ex Nyl. $\equiv$ Phaeographis aequabilis

afzelii Ach. $\equiv$ Dyplolabia afzelii

\section{alboglaucescens Adaw. \& Makhija}

Pamplemousses: Jardin Botanique, on bark of Agathis, 2016, Ertz 21469.

New for Mauritius.

analoga Nyl. Reported from Rodrigues, on bark of trees, 1874, Balfour 2218, by Crombie (1876b).

anfractuosa (Eschw.) Eschw. Reported from Mauritius by Daruty (1873).

anguina (Mont.) Nyl. Reported from Mauritius by Daruty (1873).

angustata Eschw. $\equiv$ Allographa angustata

assimilis Nyl. Reported from Rodrigues, on bark of trees, 1874, Balfour 2312, by Crombie (1876b).

cincta (Pers.) Aptroot

Pamplemousses: Jardin Botanique, on bark of Agathis, 2016, Ertz 21465.

New for Mauritius. comma (Ach.) Spreng. $\equiv$ Allographa comma

contexta (Pers.) Nyl. Reported from Mauritius by Daruty (1873).

\section{duplicata Ach.}

$\equiv$ Opegrapha duplicata (Ach.) Bél.

Port Louis and Moka: Along trail from Moka to Le Pouce, on bark, 2019, Ertz 24106, 24107.

This species was reported by Bélanger (1834) 'Sur l'écorce des arbres, dans la péninsule indienne, aux îles Maurice et de Bourbon'.

\section{*gomphospora Müll. Arg.}

J. Linn. Soc., Bot. 30: 458 (1895). Type: Mauritius, Pic du Pouce (G 00047550).

This species belongs to Fissurina (https://www.fieldmuseum.org/sites/default/files/online_supplement_T1.txt) but has not yet formally been transferred there.

\section{librata C. Knight}

Reported from Moka, below Mt Ory, $200 \mathrm{~m}$, on a shaded tree, 1990, Hawksworth (K-IMI) by David \& Hawksworth (1995) and Crittenden et al. (1995).

\section{pallescens Vain.}

Reported from Moka, Nouvelle Découverte, $3 \mathrm{~km} \mathrm{~N}$ of village, $300 \mathrm{~m}$, on bark, 1990, Hawksworth (K-IMI) by David \& Hawksworth (1995) and Crittenden et al. (1995).

pulverulenta (Pers.) Ach. [三 Graphis scripta var. pulverulenta (Pers.) Ach.]. Reported from Mauritius by Daruty (1873).

\section{pyrrhocheiloides Zahlbr.}

Pamplemousses: Jardin Botanique, on bark of Verschaffeltia splendens, 2016, Ertz 21435.

New for Mauritius.

rugulosa (Fée) Spreng. [三 Opegrapha rugulosa Fée]. 'Sur l'écorce des arbres, à l'île Maurice' (Bélanger 1834).

scalpturata Ach. $\equiv$ Phaeographis scalpturata

scripta (L.) Ach. Reported from Mauritius by Daruty (1873). scripta var. pulverulenta (Pers.) Ach. $\equiv$ Graphis pulverulenta turgidula Müll. Arg. = Allographa rustica

uniformis Fée. Reported from Mauritius by Daruty (1873).

\section{GYALECTA Ach.}

"tropica Bél., Voyage aux Indes-orientales, pendant les années 1825-1829: 127 (1834). Type: 'Sur l'écorce des arbres, à l'île Maurice’ (PC 0027547) (Bélanger 1834).

\section{GYALECTIDIUM Müll. Arg.}

filicinum Müll. Arg.

Reported from Mauritius, foliicolous on Acrostichum obductum (S) by Santesson (1952: 358).

\section{GYALOLECHIA A. Massal.}

bassiae (Ach.) Søchting, Frödén \& Arup ex Ahti

$\equiv$ Caloplaca bassiae (Ach.) Zahlbr.

${ }^{*}=$ Lecanora aurantiaca var. isidiosella Cromb., Journ. Linn. Soc., Bot. 15: 437 (1876); 三 Caloplaca isidiosella (Cromb.) R. Sant., in Moberg, Thunbergia 5: 3 (1987). Type: 
Rodrigues, on the bark of trees, 1874, Balfour 2211 (BR 5030019351485, isotype; BM, syntypes) (Crombie 1876b).

Moka: Réduit, State House Park, on bark, 2019, Diederich 18718.

Further reported from Mauritius, Søchting 9748 (C) by Arup et al. (2013), and from Pamplemousses Botanical Garden, 1990, Hawksworth (K-IMI) by David \& Hawksworth (1995) and Crittenden et al. (1995).

Wetmore (2004: 289) included L. aurantiaca var. isidiosella in the synonymy of G. bassiae and stated that he did not find the type specimen (Balfour 2336) in BM. However, the type of var. isidiosella is specimen Balfour 2211, while specimen Balfour 2336 was published as Lecanora aurantiaca by Crombie (1876b), a name currently considered a synonym of Gyalolechia flavorubescens.

flavorubescens Søchting, Frödén \& Arup [= Lecanora aurantiaca (Lightf.) Flot.]. Reported from Rodrigues, on bark of trees, 1874, Balfour 2336, by Crombie (1876b).

\section{HAEMATOMMA A. Massal.}

africanum (Steiner) Dodge

Rivière Noire: Trail from Plaine Champagne towards Piton de la Petite Rivière Noire, on branches of a tree, 2016, Diederich 18462.

Previously reported from Rodrigues, on bark of trees, 1874, Balfour 2238 (BM) by Staiger \& Kalb (1995). New for the island of Mauritius.

\section{collatum (Stirton) Dodge}

Reported from Mauritius, Plains, 1857, Ayres (BM), 1873, Weddell $(\mathrm{H})$, and 1867 (BM-Hooker) by Staiger \& Kalb (1995).

\section{persoonii (Fée) A. Massal.}

Reported from Mauritius, 1860, Ayres (BM) by Staiger \& Kalb (1995).

puniceum (Sw.) A. Massal. [三Lecanora punicea (Sw.) Ach.; $\equiv$ Parmelia punicea (Sw.) Ach.]. Reported from Mauritius (Daruty 1873), from Rodrigues, 1874, Balfour 2238 (Crombie 1876b), and 'Sur l'écorce des arbres, aux îles Maurice et de Java' (PC 0018860) (Bélanger 1834). The report from Rodrigues refers to $H$. africanum; the two other reports are almost surely erroneous, as $H$. puniceum is a rare species known only from Peru (Staiger \& Kalb 1995).

HEPPIA Nägeli ex A. Massal.

rodriguesii Cromb. $\equiv$ Peltula rodriguesii

\section{HETERODERMIA Trevis.}

comosa (Eschw.) Follmann \& Redón [三 Anaptychia comosa (Eschw.) A. Massal.]. Reported from Mauritius, 'auf Ästen' by Lindau (1908).

hypoleuca (Mühl.) Trevis. $\equiv$ Polyblastidium hypoleucum japonica (Satō) Swinscow \& Krog $\equiv$ Polyblastidium japonicum

\section{obscurata (Nyl.) Trevis.}

Port Louis and Moka: Along trail from Moka to Le Pouce, on rock, 2019, Ertz 24103 (TLC: atranorin, zeorin, cf 16ß-acetoxyhopane-6 $\alpha, 22$-diol, cf. 7-chloroemodin, solvent A). Rivière Noire: Chamarel, Ebony Forest, around viewpoint, on rock, 2019, Ertz 23552 (TLC: atranorin, zeorin, cf 16ß-acetoxyhopane-6a,22-diol, cf. 7-chloroemodin, solvent $\mathrm{A}$ ).

Previously reported from Mauritius by Crittenden et al. (1995). A further unpublished specimen, 1874, Balfour is kept in $\mathrm{E}$.

speciosa (Wulfen) Trevis. [三 Anaptychia speciosa (Wulfen) A. Massal.; E Physcia speciosa (Wulfen) Nyl.]. Reported from Mauritius by Daruty (1873) and Lindau (1908), and from Rodrigues, on trees and rocks, 1874, Balfour 2289, 2324, by Crombie (1876b).

\section{HYPERPHYSCIA Müll. Arg.}

\section{adglutinata (Flörke) H. Mayrh. \& Poelt}

Moka: Réduit, State House Park, on bark, 2019, Diederich 18730 \& Ertz 23254; ibid., on bark of Ficus microcarpa, 2019, Diederich 19281. Pamplemousses: $1 \mathrm{~km} \mathrm{NNW}$ of Botanical Garden, S of Museum 'Aventure du sucre', on bark, 2016, Diederich 18510, 18621; Jardin Botanique, on twigs, 2016, Diederich 18585. Rivière Noire: Chamarel, near Seven Coloured Earths, on branches, 2016, Diederich 18627; Le Morne Peninsula, S coast, on bark, 2019, Diederich 19440.

A further unpublished specimen, collected by Jørgensen in Pamplemousses in 1997, is kept in BG (L 34990). New for Mauritius.

\section{HYPOGYMNIA (Nyl.) Nyl.}

"inflata Dodge, Ann. Missouri Bot. Gard. 46 : 47 (1959). Type: Mauritius, growing with hepatics (BM).

\section{HYPOTRACHYNA (Vain.) Hale}

microblasta (Vain.) Hale

*= Parmelia mauritiana Gyeln., Repert. Spec. Nov. Regni Veg. 29: 288/416 (1931b), nom. nov. for P. caraccensis $\mathrm{f}$. isidiosa; $\equiv$ Pseudevernia mauritiana (Gyeln.) Dodge, Ann. Missouri Bot. Gard. 46: 182 (1959); 三 Parmelia caraccensis f. isidiosa Müll. Arg., Flora 74: 376 (1891). Type: Mauritius (K, holotype; BM 000550359, isotype; G 00066546, isotype) (Hale 1968, 1971: 18).

Also reported from Macchabee Forest, 1990, Hawksworth (K-IMI) by David \& Hawksworth (1995) and Crittenden et al. (1995), and from road between Mt Cocotte and Bassin Blanc, 1991, Krog \& Timdal (O) by Lücking \& Timdal (2016: 194). Further unpublished specimens from Piton de la Petite Rivière Noire, Curepipe (Trou aux Cerfs) and Mt Cocotte, collected by Krog in Timdal in 1991, are kept in $\mathrm{O}$.

\section{JULELLA Fabre}

geminella (Nyl.) R. C. Harris

Rivière Noire: Chamarel, Ebony Forest, close to park buildings, on bark, 2016, Diederich 18548.

New for Mauritius.

\section{KROGIA Timdal \\ *coralloides Timdal}

Lichenologist 34: 293 (2002). Type: Black River, along path from Plaine Champagne towards Piton de la Petite Rivière Noire, 15 Nov. 1991, Krog \& Timdal MAU51/83 
(O-L-21909, holotype); ibid., Krog \& Timdal MAU51/80 (O-L-21908, BM, M, UPS, paratypes) (Timdal 2002, Kistenich et al. 2018: 903).

Rivière Noire: Trail from Plaine Champagne towards Piton de la Petite Rivière Noire, on bark, 2016, Diederich 18455 (det. Timdal).

\section{LECANOGRAPHA Egea \& Torrente}

\section{subnothella (Nyl.) Ertz}

Pamplemousses: Sir Seewoosagur Ramgoolam Botanical Garden, on bark, 2014, Ertz 19162; ibid., on bark of Terminalia, 2016, Ertz 21447.

In specimen Ertz 21447, most of the lirellae have a whitish pruina, but others are yellowish pruinose, showing that this species might, surprisingly, have two types of pruina. New for Mauritius.

\section{LECANORA Ach.}

*achroa Nyl. ex Cromb.

J. Bot. 14: 263 (1876). Type: Rodrigues, on bark of trees, 1874, Balfour 2311 (H-NYL 27475, lectotype, selected by Lumbsch \& Feige 1995; H-NYL 27293, isolectotype; E, isolectotype?) (Crombie 1876a, b; Lumbsch et al. 1995; Papong \& Lumbsch 2011).

*= achroella Nyl. ex Cromb., J. Bot. 14: 263 (1876). Type: Rodrigues, on bark of trees, 1874, Balfour 2255 (H-NYL 27135, holotype) (Crombie 1876a, b; Lumbsch et al. 1995).

*= subflavicans Nyl. ex Cromb., J. Bot. 14: 264 (1876). Type: Rodrigues, corticole, on bark of trees, 1874, Balfour 2223 (H-NYL 27287, holotype) (Crombie 1876a, b; Lumbsch et al. 1995).

A rather common, corticolous, pantropical species (Lumbsch et al. 1995).

achroella Nyl. ex Cromb. = Lecanora achroa

albella (Pers.) Ach. Reported from Mauritius by Daruty (1873).

allophana (Ach.) Nyl. [三 Lecanora subfusca var. allophana Ach.]. Reported from Mauritius by Daruty (1873).

apostatica Nyl. ex Cromb. $\equiv$ Loekoesia apostatica

apostatica var. obliquans Nyl. ex Cromb. = Loekoesia apostatica

argentata (Ach.) Malme [三Lecanora subfusca var. argentata

Ach.]. Reported from Mauritius by Daruty (1873).

atra (Hudson) Ach. $\equiv$ Tephromela atra

atra f. succedanea Nyl. =? Tephromela atra (Huds.) Hafellner aurantiaca (Lightf.) Flot. = Gyalolechia flavorubescens

aurantiaca var. isidiosella Cromb. = Gyalolechia bassiae

aurantiella Nyl. ex Cromb. $\equiv$ Caloplaca aurantiella

campestris (Schaer.) Hue. Reported from Mauritius by Crittenden et al. (1995).

caesiorubella Ach. Reported from Mauritius by Daruty (1873).

carneofusca Nyl. ex Cromb. $\equiv$ Caloplaca diplacia var. carneofusca

cinnabarina Ach. $\equiv$ Brownliella cinnabarina

coniopta Nyl. = Rinodina luridescens conizaea (Ach.) Nyl. Reported from Rodrigues, on decorticated trunks, 1874, Balfour 2335 by Crombie (1876b).

*conizopta Nyl. ex Cromb., J. Bot. 14: 263 (1876). Type: Rodrigues, 'corticole' (Crombie 1876a) or 'on rocks' (Crombie 1876b) [photos on JSTOR suggest rocks], 1874, Balfour 2217 (H-NYL 26146, holotype [fide Lumbsch 1994: 156]; $\mathrm{M}$, isotype) (Crombie 1876a, b).

glaucofuscula Nyl. ex Cromb. 三 Caloplaca glancofuscula glaucofuscula f. biatoroidea Cromb., see under Caloplaca

leucoxantha Müll. Arg. Reported from Rodrigues, on bark of trees, 1874, Balfour 2366, by Crombie (1876b).

muralis (Schreb.) Rabenh. Reported from Mauritius by Riedl \& Riedl-Dorn (1986).

murorum (Hoffm.) Ach. Reported from Mauritius by Hue (1892: 128).

murorum var. lobulata (Sommerf.) Schaer. $\equiv$ Bilimbia lobulata

oreinoides (Körb.) Hertel \& Rambold

${ }^{*}=$ ? Lecidea melopta Nyl. ex Cromb., J. Bot. 14: 264 (1876). Type: Rodrigues, on rocks, 1874, Balfour 2281 (E, G, H, UPS L076078) (Crombie 1876a, b).

Following http://data.rbge.org.uk/herb/E00465221, the type of Lecidea melopta in E belongs to L. oreinoides.

parella var. pallescens $(\mathrm{L}$.$) Ach. \equiv$ Ochrolechia pallescens

parella var. phloeoleuca Nyl. = Ochrolechia africana

"perlutescens Nyl. ex Cromb., J. Bot. 14: 263 (1876). Type: Rodrigues, on bark of trees, 1874, Balfour 2222 (H-NYL 26299) (Crombie 1876a, b).

punicea (Sw.) Ach. $\equiv$ Haematomma puniceum

sorediifera Fée [三 Parmelia sorediifera (Fée) Bél.]. 'Sur les écorces d'arbres, à l'île Maurice' (Bélanger 1834).

subflavicans Nyl. ex Cromb. = Lecanora achroa

subfusca (L.) Ach. Reported from Mauritius, Round Island, on west side of the island, on dead branches of Fernelia buxifolia, $200 \mathrm{ft}$ by Johnston (1894: 263).

subfusca ['subfurea'] var. allophana ['allofara'] Ach. $\equiv$ Lecanora allophana

subfusca ['subfurea'] var. argentata Ach. $\equiv$ Lecanora argentata

"subfusca f. pumicicola Nyl., in Crombie, Journ. Linn. Soc., Bot. 15: 438 (1876). Type: Rodrigues, on rocks, 1874, Balfour 2296, 2299 (M, type?; UPS L106912, in database sub Lecanora pseudistera) (Crombie 1876b).

sulphureofusca Fée $\equiv$ Sipmaniella sulphureofusca

vigilans Taylor $=$ Megalospora coccodes subsp. coccodes

\section{LECIDEA Ach}

*achroopholis Nyl. ex Cromb., J. Bot. 14: 264 (1876); 三 Psora achroopholis (Nyl. ex Cromb.) C. W. Dodge, Beih. Nova Hedwigia 12: 230 (1964). Type: Rodrigues, on rocks, 1874, Balfour 2272 (E, H-NYL 13024) (Crombie $1876 \mathrm{a}, \mathrm{b})$.

canorubella Nyl. Reported from Mauritius by Daruty (1873). coccocarpioides Nyl. ex Cromb. $\equiv$ Rolfidium coccocarpoides compacta Nyl. $\equiv$ Phyllopsora compacta 
*configurans Nyl. ex Cromb., J. Bot. 14: 264 (1876). Type: Rodrigues, on rocks, 1874, Balfour 2224 (E, H) (Crombie 1876a, b).

continens Nyl. ex Cromb. $\equiv$ Buellia continens

disciformis Nyl. Reported from Mauritius by Daruty (1873) and from Rodrigues, on bark of trees, 1874, Balfour 2331, by Crombie (1876b).

immutans Nyl. ex Cromb. $\equiv$ Buellia immutans

*leucoxantha var. bispora Nyl., Mém. Soc. Imp. Sci. Nat. Cherbourg 5: 123 (1857), nom. nud. (description missing). Original material: 'Guyan., ins. Maurit.'.

*leucoxantha var. ochrocarpa Nyl., Mém. Soc. Imp. Sci. Nat. Cherbourg 5: 123 (1857), nom. nud. (description missing). Original material: 'Ins. Maurit.'.

mauritiana Taylor $\equiv$ Phyllopsora mauritiana

megacarpa Nyl. = Megalospora sulphurata

megaspora Leight. = Megalospora sulphurata

melopta Nyl. ex Cromb. $=$ ? Lecanora oreinoides

mutabilis Fée. Reported from Mauritius by Daruty (1873).

spuria Schaer. $\equiv$ Buellia spuria

triphragmia Nyl. = Buellia geophila

tuberculosa Fée $\equiv$ Megalospora tuberculosa

vulpina Tuck. $\equiv$ Letrouitia vulpina

\section{LEIODERMA Nyl.}

erythrocarpum (Nyl.) D. J. Galloway \& P. M. Jørg.

Rivière Noire: Trail from Plaine Champagne towards Piton de la Petite Rivière Noire, on bark, 2019, Ertz 23998. Savanne: Along trail to Mt Cocotte, on bark, 2019, Diederich 18864 \& Ertz 23508, 23512.

Also reported from Piton de la Petite Rivière Noire by Timdal (2002: 296), from Curepipe, 1933, Vaughan (BM), Plaine Champagne, $20 \mathrm{~km} \mathrm{~S}$ of Rose Hill, 1979, Arvidsson \& Nilsson (GB), Plaine Raoul, $15 \mathrm{~km} \mathrm{~S}$ of Rose Hill, 1979, Arvidsson \& Nilsson (GB) by Galloway \& Jørgensen (1987), from entrance to Macchabee Forest, 1990, Hawksworth (K-IMI) by David \& Hawksworth (1995) and Crittenden et al. (1995), and from road between Mt Cocotte and Bassin Blanc, 1991, Krog \& Timdal (O) by Lücking $\&$ Timdal (2016: 194). Further unpublished specimens from the Macchabee Forest, Le Pouce and Mt Cocotte, collected by Krog \& Timdal in 1991, are kept in O.

\section{LEPIDOCOLLEMA Vain.}

brisbanense (C. Knight) P. M. Jørg.

$*=$ ? Pannaria rubiginosa var. dispartita Nyl., in Crombie, J. Linn. Soc. (Bot.) 15: 436 (1876b); $\equiv$ P. dispartita (Nyl.) Vain. Type: Rodrigues, on rotten stumps on the ground, 1874, Balfour (BM, lectotype, selected by Jørgensen 2003).

Plaines Wilhems: Curepipe, Curepipe Botanic Gardens, on bark, 2016, Diederich 18300 (dupl. LG); Le Pétrin, heathland NW of Pétrin Information Centre, on bark, 2019, Diederich 18832; Le Pétrin, between Pétrin Information Centre and first viewpoint along trail to the west, on bark, 2016, Diederich 18333 (dupl. LG), 18334. Rivière Noire: Trail from Plaine Champagne towards Piton de la Petite Rivière Noire, on bark, 2016, Diederich 18435 (dupl. LG),
18440 (dupl. LG), 18446; east of Black River, from Visitor's Centre to Pilgrims Trail, on bark, 2016, Diederich 18482 (MAU), 18495, 18496 (dupl. LG), 18497 (dupl. LG), 18498 (dupl. LG).

Following Jørgensen (2003), the type of Pannaria rubiginosa var. dispartita belongs to 'Parmeliella stylophora s.lat.'. As the distinction between Lepidocollema stylophorum (Vainio) P. M. Jørg. and L. brisbanense needs further investigation [Jørgensen (2000) even suggested that the mainly neotropical $L$. stylophorum may be a later synonym of $L$. brisbanense], we have provisionally included all isidiate specimens in L. brisbanense.

New for Mauritius.

marianum (Fr.) P. M. Jørg.

*= Pannaria luridula Nyl. ex Cromb., J. Bot. 14: 263 (1876). Type: Rodrigues, on the ground, 1874, Balfour 2208 (HNYL 31278, holotype) (represents L. marianum, det. Jørgensen 2002) (Crombie 1876a, b).

Further unpublished specimens from Mt Cocotte, collected by Krog \& Timdal in 1991, are kept in O.

\section{LEPRA Scop.}

\section{amara (Ach.) Hafellner}

Rivière Noire: Trail from Plaine Champagne towards Piton de la Petite Rivière Noire, on bark, 2016, Diederich 18397, 18430 (det. Kukwa; TLC: picrolichenic).

This is a surprising discovery of a mainly temperate species. New for Mauritius.

\section{LEPRARIA Ach}

arbuscula (Nyl.) Lendemer \& B. P. Hodk.

इStereocaulon arbuscula $\mathrm{Nyl} . ;$ E Leprocaulon arbuscula (Nyl.) Nyl.

Reported from Mauritius, 1869, Peck (CAN, FH) (Lamb 1966, Lamb \& Ward 1974: 518).

\section{cf. elobata Tønsberg}

Rivière Noire: Chamarel, Ebony Forest, along trail to viewpoint, $\sim 50 \mathrm{~m}$ before viewpoint, terricolous, on vertical banks of road protected from rain, 2016, Diederich 18522 (det. Kukwa; dupl. UGDA).

Following Kukwa (pers. comm.), this specimen is very close to Lepraria elobata. It has small, more or less regular greyish granules and lacks projecting hyphae, typical for this species; however, the granules are a bit smaller than in typical specimens and form a really thick layer, which is rather atypical for L. elobata. Although the entire variation of the species may not be known, especially in the tropics, it is possible that the examined specimen is old, resulting in a relatively thick layer of granules. New for Mauritius.

finkii (B. de Lesd.) R. C. Harris

Plaines Wilhems: Curepipe, Curepipe Botanic Gardens, on bark, 2016, Diederich 18295, 18310; ibid., 2019, Diederich 19152; Le Pétrin, along trail W of Pétrin Information Centre, up to $600 \mathrm{~m} \mathrm{~W}$ of first viewpoint, on bark, 2019, Diederich 18767. Rivière Noire: Trail from Plaine Champagne towards Piton de la Petite Rivière Noire, on bark, 2016, Diederich 18397, 18403; Brise Fer Forest, on bark, 2019, Diederich 19238 (all det. Kukwa dupl. UGDA).

New for Mauritius. 
flava (Willd.) Ach. $=$ Chrysothrix candelaris

\section{pallida Sipman}

Rivière Noire: Trail from Plaine Champagne towards Piton de la Petite Rivière Noire, on bark, 2016, Diederich 18611 (det. Kukwa; TLC: atranorin, zeorin, fatty ac.).

New for Mauritius.

\section{LEPROCAULON Nyl.}

arbuscula (Nyl.) Nyl. $\equiv$ Lepraria arbuscula

\section{LEPTOGIUM (Ach.) Gray}

\section{azureum (Sw.) Mont.}

$\equiv$ Collema azureum (Sw.) Ach.; इ Leptogium tremelloides var. azureum (Sw.) Nyl.

Plaines Wilhems: Curepipe, Curepipe Botanic Gardens, on bark, 2016, Diederich 18306; ibid., 2019, Diederich 19099, 19199. Port Louis and Moka: Along trail from Moka to Le Pouce, on bark, 2019, Ertz 24101. Rivière Noire: Trail from Plaine Champagne towards Piton de la Petite Rivière Noire, on bark, 2016, Diederich 18449; ibid., 2019, Ertz 23919; east of Black River, from Visitor's Centre to Pilgrims Trail, on bark, 2016, Diederich 18479; Chamarel, Ebony Forest, around viewpoint, on bark, 2016, Diederich 18555; ibid., along trail W of viewpoint, on bark, 2019, Diederich 18944, 18947, 19403 \& Ertz 23572. Savanne: Along trail to Mt Cocotte, on bark, 2019, Diederich 19386 \& Ertz 23464.

Previously reported from Mauritius by Daruty (1873) by Crittenden et al. (1995), and 'Sur l'écorce des arbres, dans les lieux humides des forêts' by Bélanger (1834) (PC 0071319).

burgessii (L.) Mont. [三 Collema burgessii (L.) Ach.] 'Sur les arbres, dans les forêts des îles Maurice et de Java' (Bélanger 1834).

cyanescens (Rabenh.) Körb.

Plaines Wilhems: Curepipe, Curepipe Botanic Gardens, on bark, 2016, Diederich 18309. Rivière Noire: Trail from Plaine Champagne towards Piton de la Petite Rivière Noire, on bark, 2016, Diederich 18415, 18439; ibid., 2019, Ertz 23920; east of Black River, from Visitor's Centre to Pilgrims Trail, on bark, 2016, Diederich 18475; Chamarel, Ebony Forest, around viewpoint, on bark, 2016, Diederich 18552 , 18553 \& Ertz 23565; ibid., along trail W of viewpoint, on bark, 2019, Diederich 18933, 18940 \& Ertz 23580, 23611 p.p. Le Morne Peninsula, S coast, on bark, 2019, Ertz 24273. Savanne: Along trail to Mt Cocotte, on bark, 2019, Diederich 18898 .

Also reported from Mauritius by Crittenden et al. (1995) and from Ile aux Aigrettes by Parnell et al. (1989) (BM, det. James).

*fuliginellum Wedd., in Daruty, Trans. Roy. Soc. Arts Mauritius, n.s. 7: 164 (1873), nom. nud. (description missing).

\section{marginellum (Sw.) Gray}

三Collema marginellum (Sw.) Raeusch.

Port Louis and Moka: Along trail from Moka to Le Pouce, on bark, 2019, Ertz 24047. Rivière Noire: Chamarel, Ebony Forest, around viewpoint, on bark, 2016, Diederich 18550; ibid., along trail W of viewpoint, on bark, 2019, Diederich 18929 \& Ertz 23579.
Previously reported from Mauritius by Bélanger (1834) (PC 0071380). An unpublished specimen from Le Pouce, collected by Krog \& Timdal in 1991, is kept in O.

mastocheilum (Vain.) Kitaura \& Marcelli

Rivière Noire: Chamarel, Ebony Forest, around viewpoint, on bark, 2016, Diederich 18551; ibid., along trail W of viewpoint, on bark, 2019, Diederich 18924, 18930 \& Ertz 23611; trail from Plaine Champagne towards Piton de la Petite Rivière Noire, on bark, 2016, Diederich 18618.

New for Mauritius.

phyllocarpum (Pers.) Mont. Reported from Mauritius by Daruty (1873).

tremelloides (L. f.) Gray. Reported from Mauritius by Daruty (1873) and Lindau (1908), 1889, fr. Rodriguez by Hue (1898: 223), and from Rodrigues, on trunks of trees, 1874 , Balfour 2201, by Crombie (1876b).

tremelloides var. azureum Nyl. $\equiv$ Leptogium azureum

tremelloides var. rugulosum Nyl. Reported 'In ins. Mauritii, sur les rochers humides et les arbres, à Plaisance, près de Rose-Hill, Daruty 90, 30 mai 1873' by Hue (1898).

\section{LETROUITIA Hafellner \& Bellem.}

vulpina (Tuck.) Hafellner \& Bellem.

$\equiv$ Lecidea vulpina Tuck.

Rivière Noire: Trail from Plaine Champagne towards Piton de la Petite Rivière Noire, on bark, 2016, Diederich 18420; Chamarel, Ebony Forest, along trail W of viewpoint, on bark of Diospyros tessellaria, 2019, Diederich 19399.

Previously reported from Mauritius by Hue (1892: 200), ex herb. Hooker (H-NYL 18038) by Hafellner (1981: 718), and from Brise de Fer, 2001, Søchting (C) and Le Pouce, 2001, Søchting (C) by Johannson et al. (2005: 148).

\section{LEUCODERMIA Kalb}

leucomelos (L.) Kalb [三 Anaptychia leucomelaena (L.) A. Massal.]. Reported from Mauritius by Lindau (1908).

\section{LICHEN L.}

floridus L. $\equiv$ Usnea florida

roccella $\mathrm{L}$. The report from Mauritius by Flörke (1809) probably refers to Roccella boryi.

\section{LICHENOPELTELLA Höhn.}

+ramalinae Etayo \& Diederich

Rivière Noire: Trail from Plaine Champagne towards Piton de la Petite Rivière Noire, 2016, on bark, on Ramalina sprengelii, Diederich 18458.

This lichenicolous ascomycete, confined to Ramalina hosts, is new for Mauritius.

\section{LOBARIA (Schreb.) Hoffm.}

holstiana (Müll. Arg.) Zahlbr.

Reported from Le Pouce, 600 m, 2001, by Holm \& Gregersen (2002). Further unpublished specimens from Plaine Champagne towards Piton de la Petite Rivière Noire and Mt Corps de Garde, collected by Krog \& Timdal in 1991, are kept in $\mathrm{O}$. 


\section{patinifera (Taylor) Hue}

Reported from Mt des Créoles, 1991, Krog \& Timdal (MAU, O) by Lücking \& Timdal (2016: 198). Further unpublished specimens from Le Pouce, Piton de la Petite Rivière Noire, Mt Corps de Garde and Macchabee Forest, collected by Krog \& Timdal in 1991, are kept in O.

pulmonaria (L.) Hoffm. [= Sticta pulmonacea (Ach.) Ach.]. Reported from Mauritius by Laurer (1827).

\section{retigera (Bory) Trevis.}

Rivière Noire: Trail from Plaine Champagne towards Piton de la Petite Rivière Noire, on bark, 2016, Diederich 18400 (dupl. LG). Savanne: Along trail to Mt Cocotte, on bark, 2019, Diederich 18853, 18861.

Previously reported from Mauritius by Lindau (1908) and from le Pouce, 600 m, 2001, by Holm \& Gregersen (2002). Further unpublished specimens from Le Pouce, Plaine Champagne towards Piton de la Petite Rivière Noire, Grand Bassin and Mt Cocotte, collected by Krog \& Timdal in 1991, are kept in O.

wightii Dodge $=$ Ricasolia sublaevis

\section{LOBARIELLA Yoshim.}

crenulata (Hook. f.) Yoshim. [三 Parmelia crenulata Hook f.]. 'Sur l'écorce des arbres, à l'île Maurice' (Bélanger 1834).

\section{LOEKOESIA S. Y. Kondr., S.-O. Oh \& Hur}

\section{"Loekoesia apostatica (Nyl. ex Cromb.) Ertz \& Diederich,} comb. nov.

(Figs 9-10)

\section{MycoBank MB 834924}

Basionym: Lecanora apostatica Nyl. ex Cromb., J. Bot. 14: 263 (1876); 三 Lecidea apostatica (Nyl. ex Cromb.) Hue, Nouvelles archives du Muséum d'histoire naturelle, sér. 5, 4: 9 (1914); 三 Blastenia apostatica (Nyl. ex Cromb.) Zahlbr., Cat. Lich. Univ 7: 24 (1930); 三 Huea apostatica (Nyl. ex Cromb.) C. W. Dodge, Beih. Nova Hedwigia 38: 84 (1971). Type: Rodrigues, on rocks, 1874, Balfour (BM 001096467!, lectotypus hic designatus; E, H, syntypes, non vid.).

MycoBank MBT 391339

*Syn. nov.: Lecanora apostatica var. obliquans Nyl. ex Cromb., J. Bot. 14: 263 (1876); 三Lecidea obliquans (Nyl. ex Cromb.) Hue, Nouvelles archives du Muséum d'histoire naturelle, sér. 5, 4: 16 (1914); 三 Blastenia obliquans (Nyl. ex Cromb.) Zahlbr., Cat. Lich. Univ. 7: 37 (1930); $\equiv$ Huea obliquans (Nyl. ex Cromb.) C. W. Dodge, Beih. Nova Hedwigia 38: 87 (1971). Type: Rodrigues, on rocks, 1874, Balfour (BM 001096465!, lectotypus hic designatus; BM 001096466!, BM 001096467!, BM 001096469!, BM 001096471!, syntypes; E, H, syntypes, non vid.).

\section{MycoBank MBT 391340}

Description. Thallus white to pale yellowish or greyish, varying from thin and continuous to thick and cracked or areolate, up to $0.3 \mathrm{~mm}$ thick. Apothecia abundant, dispersed, sessile with a constricted base, $0.4-0.8 \mathrm{~mm}$ diam.; disc slightly concave, brownish to greenish black, becoming dark greenish in damaged areas, without pruina; proper margin greenish black, 70-100(-120) $\mu \mathrm{m}$ thick, often becoming slightly to strongly undulate, some apothecia eventually becoming gyrose; thalline margin absent. Hymenium not inspersed, hyaline, in the upper part bluish green, $80-140 \mu \mathrm{m}$ thick; epihymenium not granulose, with a bluish green, $\mathrm{K}$ - pigment, additionally appearing brownish because of the paraphyses tips; hypothecium hyaline, 50-100 $\mu \mathrm{m}$ thick; exciple $80-120 \mu \mathrm{m}$, outer layer greenish, $\mathrm{K}-$, inner layer hyaline, of rounded cells 4.5-7 $\mu \mathrm{m}$ diam. Paraphyses branched in the middle or close to the apex, $2-2.5 \mu \mathrm{m}$ thick, apically brownish, up to $3 \mu \mathrm{m}$. Asci claviform, wall apically thickened, 8-spored, 44-62 × 12-22 $\mu \mathrm{m}$. Ascospores polarilocular, ellipsoid, 16-18 × 7-8.5 $\mu \mathrm{m}$ (Diederich $18400)$, or (11-)12-16 × 8-10(-10.5) $\mu \mathrm{m}$ (lectotype of L. apostatica), or $11-15 \times 5-8 \mu \mathrm{m}$ (original description), septum 2.5-4(-5) $\mu \mathrm{m}$ wide. Pycnidia immersed, blackish; pycnidial wall absent; ostiolar region bluish green, $\mathrm{K}-$; conidiophores hyaline, irregularly branched, occupying almost the entire pycnidial cavity, septate; conidiogenous cells enteroblastic, integrated into chains, acro-pleurogenous; conidia arising from the apex of a chain and laterally, hyaline, bacilliform, aseptate, $3-4 \times 1-1.5 \mu \mathrm{m}$. Chemistry: thallus $\mathrm{K}+$ yellow, $\mathrm{C}-, \mathrm{KC}-, \mathrm{PD}-, \mathrm{UV}-$; no substance detected by TLC (solvent A).

Ecology and distribution. Previously known only from Rodrigues, where the large number of specimens available in different herbaria suggests that it is a relatively common species. We collected it in one Mauritius locality near Chamarel.

Notes. Crombie (1876a) published the new species ' 8 . L. apostatica, Nyl.' and the new taxon '* L. obliquans, Nyl.'; all new species in his paper were preceded by a number, except $L$. obliquans, preceded by ${ }^{*}$. In Crombie (1876b), all new species, including $L$. apostatica, were followed by 'sp. n.', while L. obliquans was not. Several original herbarium specimens examined are annotated as 'Lecanora apostatica "obliquans Nyl.'. This clearly shows that 'obliquans' was intended to be published as a new variety, not a new species.

Crombie (1876a) published both taxa based on minor differences. Lecanora apostatica was said to be characterized by 'Thallus whitish, thin, areolato-rimose', while var. obliquans 'differs in having the thallus greyish, very thin, continuous'. Examination of five original specimens (one of L. apostatica and four of var. obliquans) and our recent material convinced us that they all belong to a single species with a rather variable thallus.

A phylogenetic analysis, using nuLSU and $\mathrm{mtSSU}$ sequences from our recent specimen, places Lecanora apostatica in a poorly supported clade comprising also the genera Eilifdahlia, Frankwilsia, Gyalolechia, Huneckia, Jasonhurea and Loekoesia. In the combined nuLSU/mtSSU tree (not shown here), the species does not group in a convincing way with any of these genera. In the mtSSU tree (Fig. 10), our species groups with Loekoesia austrocoreana but without any support, similarly to the other genera from this clade that are also not supported. No nuLSU sequences are available yet for $L$. austrocoreana.

Morphologically, Lecanora apostatica is extremely similar to Loekoesia austrocoreana. That species has a grey to greyish white, cracked or areolate thallus, black apothecia 0.4-0.7 mm diam., a plane, brownish black disc, a prominent, bluish black margin, an 80-100 $\mu \mathrm{m}$ thick, greenish blue, $\mathrm{K}$ - exciple, a 60-70 $\mu \mathrm{m}$ high hymenium with a bluish epihymenium, and ascospores $12-16 \times 5-7 \mu \mathrm{m}$ in $\mathrm{K}$ (Kondratyuk et al. 2013). It differs from L. apostatica by a thallus presenting bluish soralia, $0.3-0.5 \mathrm{~mm}$ diam., and paraphyses tips up to $4-5 \mu \mathrm{m}$. 
We conclude that Lecanora apostatica either belongs to Loekoesia or represents a distinct genus closely related to that genus. Owing to the very low molecular support and the remarkable resemblance of Lecanora apostatica and Loekoesia austrocoreana, we decided to combine L. apostatica in Loekoesia.

The species is new for the island of Mauritius.
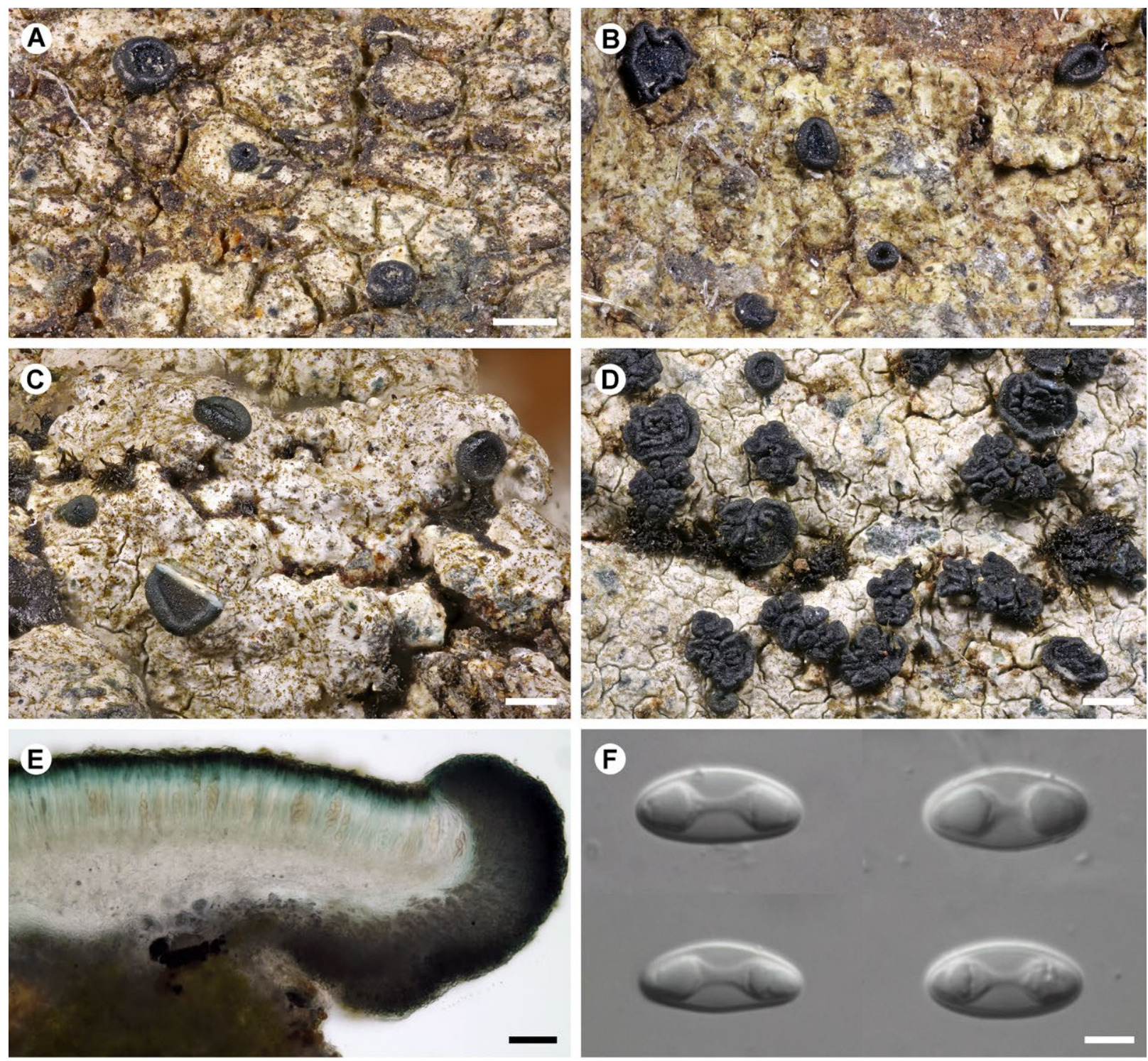

F
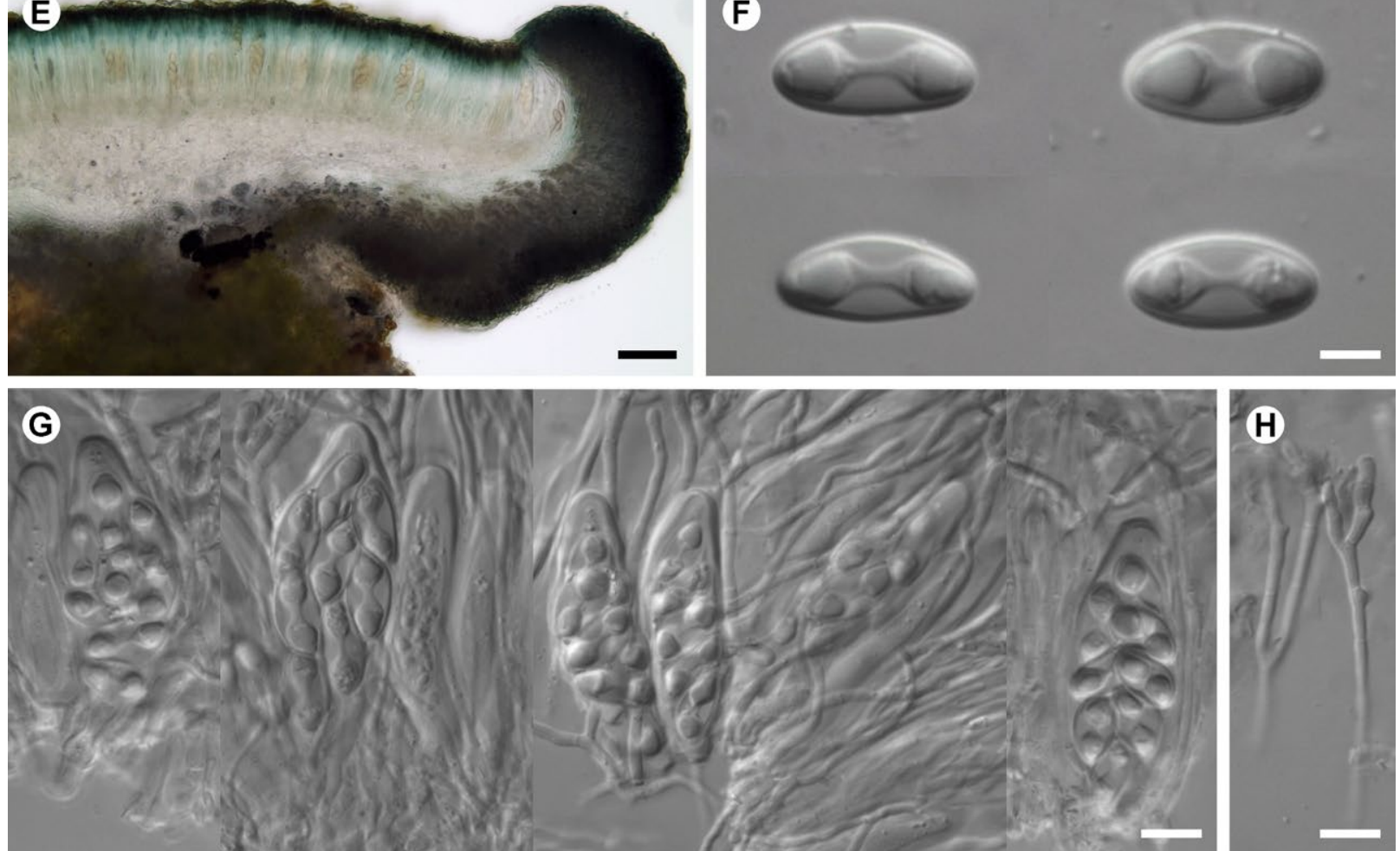

Figure 9. Loekoesia apostatica [A: lectotype of Lecanora apostatica; B: lectotype of Lecanora apostatica var. obliquans; C-H: Diederich 18518]. $\mathrm{A}-\mathrm{D}$ - thalli with apothecia; note the undulate margin of upper left apothecium in B and of most apothecia in D; E - section through apothecium, in water; $\mathrm{F}$ - ascospores, in $\mathrm{KOH}$; $\mathrm{G}$ - hymenium with paraphyses, asci and ascospores, in $\mathrm{KOH} ; \mathrm{H}$ - paraphyses, in $\mathrm{KOH}$. Scales: $\mathrm{A}-\mathrm{D}=500 \mu \mathrm{m}$; $\mathrm{E}=50 \mu \mathrm{m} ; \mathrm{F}=5 \mu \mathrm{m} ; \mathrm{G}-\mathrm{H}=10 \mu \mathrm{m}$. Photos: P. Diederich. 


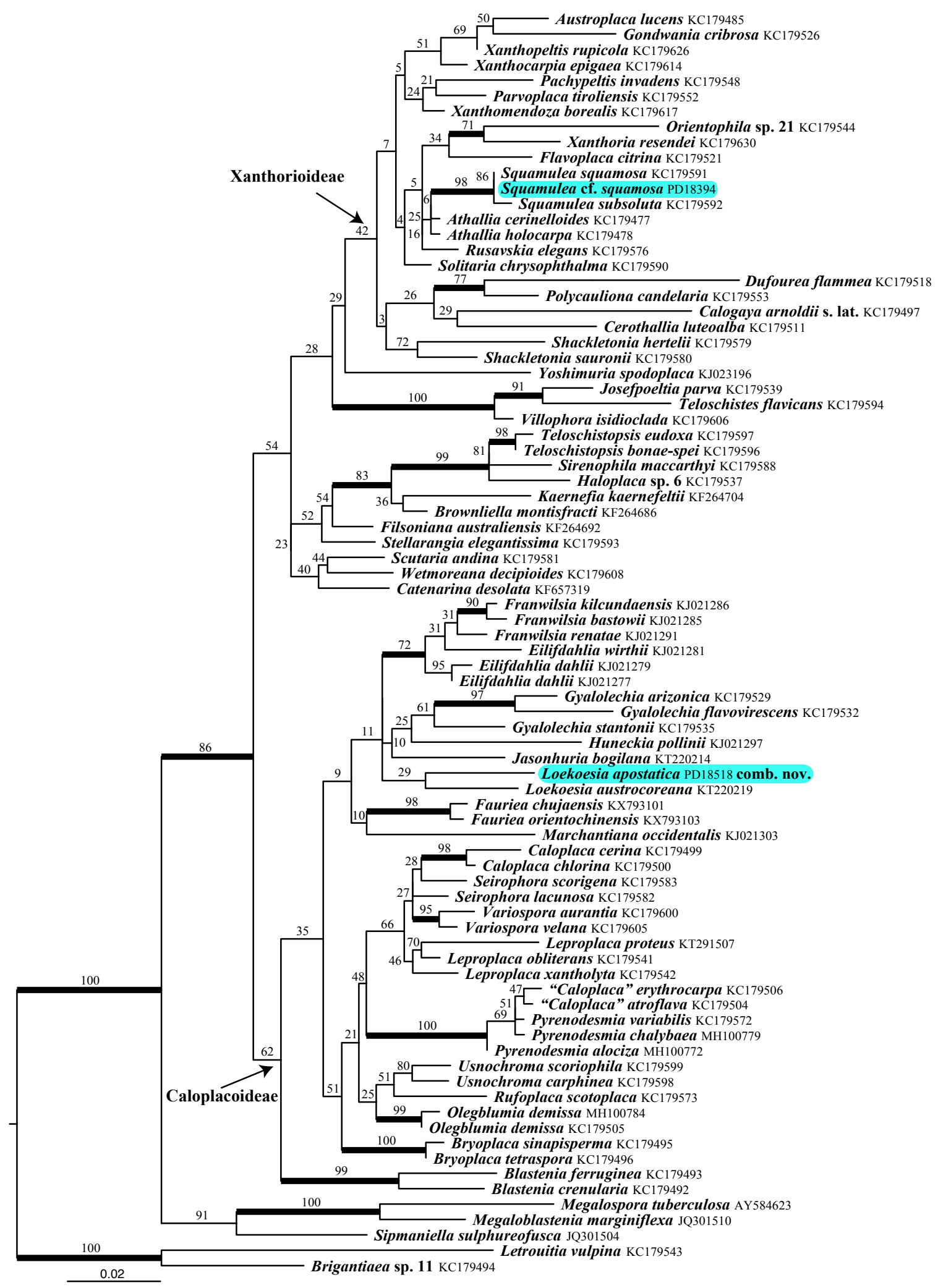

Figure 10. Phylogeny of Teloschistales based on a data set of mtSSU sequences that resulted from a RAxML analysis. Maximum likelihood bootstrap values are shown above or near internal branches. Internal branches considered strongly supported by both the RAxML and Bayesian analyses are represented by thicker lines. The newly sequenced samples from Mauritius are highlighted and their names followed by collecting numbers of authors, which act as specimen and sequence identifiers. Their respective subfamilies are indicated. 
MEDUSULA Tode

tricosa (Ach.) Mont. $\equiv$ Sarcographa tricosa

\section{MEGALOSPORA Meyen}

atrorubicans (Nyl.) A. Zahlbr. subsp. atrorubicans

Reported from Mauritius, 1867 (BM) by Sipman (1983: 96, 230).

coccodes (Bél.) Sipman subsp. coccodes

*= Lecanora vigilans Taylor, J. Bot., London 6: 159 (1847). Type: Mauritius, on bark (G 00292552, isotype; FH-Taylor, sheet 644, isotype) (Sipman 1983: 132; Taylor 1847: 159).

Also reported from Mauritius, Ayres (BM) by Sipman (1983: 230).

sulphurata Meyen s.str.

*= Lecidea megacarpa Nyl., Ann. Sci. Nat., Bot., sér. 4, 11: 260 (1859). Type: 'Ad cortices in Insula Mauritii, ex herb. cel. Fée’ (H, isotype?) (Sipman 1983: 126).

Rivière Noire: Trail from Plaine Champagne towards Piton de la Petite Rivière Noire, on bark, 2016, Diederich 18438.

Also reported from Mauritius by Daruty (1873), anon. 7 (HNYL), 'M. Bogn Hub' (BM), and Mt Pouce (G) by Sipman (1983: 126), and Pamplemousses Botanical Garden, 1990, Hawksworth (K-IMI) by David \& Hawksworth (1995) and Crittenden et al. (1995).

tuberculosa (Fée) Sipman

$\equiv$ Lecidea tuberculosa Fée

Plaines Wilhems: Le Pétrin, heathland NW of Pétrin Information Centre, on bark, 2019, Diederich 18816, 18799 \& Ertz 23325. Savanne: Along trail to Mt Cocotte, on bark, 2019, Ertz 23518.

Also reported 'Sur l'écorce des arbres, à l'île Maurice' (Bélanger 1834). Sipman (1983: 161) suggested on a distribution map (fig. 40) that this species occurs in Mauritius and Reunion; however, on p. 230, a specimen from Reunion and a second specimen from Mascarene Islands from herb. Bory de Saint-Vincent (PC-Thuret), but without indication of locality, are given. Crittenden et al. (1995) further reported the species, as M. cf. tuberculosa, from Savanne, Plaines Champagne, at viewpoint of Black River Gorge, 1990, Hawksworth (K-IMI).

\section{MELANOTREMA A. Frisch}

\section{platystomum (Mont.) A. Frisch}

Plaines Wilhems: Le Pétrin, between Pétrin Information Centre and first viewpoint along trail to the west, on bark, 2016, Diederich 18341 (TLC: no substance detected, solvent A).

New for Mauritius.

\section{MELASPILEA Nyl.}

\section{+cf. lekae Brackel \& Kalb}

Pamplemousses: Sir Seewoosagur Ramgoolam Botanical Garden, on bark of Ptychosperma macarthurii, on Phaeographis intricans, 2016, Ertz 21452.

Melaspilea lekae was described from Thailand as a lichenicolous fungus on Sarcographa labyrinthica (Kalb et al. 2012). Our specimen is on a new host genus, and the ascospores are slightly smaller. Further studies are needed.
MYCOMICROTHELIA Keissl.

leuckertii D. Hawksw. \& J. C. David $\equiv$ Bogoriella leuckertii

MYCOPORUM G. Mey.

eschweileri (Müll.Arg.) R. C. Harris

$\equiv$ Tomasellia eschweileri (Müll. Arg.) R. C. Harris

Moka: Réduit, State House Park, on bark of Phyllanthus emblica, 2019, Diederich 19300. Plaines Wilhems: Curepipe Botanic Gardens, on bark of Pinus, 2019, Diederich 19107; ibid., on bark, Diederich 19110.

Also reported from Flacq, Sandy Bay Hotel, on Cocos nucifera, 1990, Hawksworth (K-IMI) by David \& Hawksworth (1995) and Crittenden et al. (1995).

\section{MYRIOTREMA Fée}

\section{microporum (Mont.) Hale}

= Thelotrema crassulum Nyl. [fide Frisch (2006: 177)].

Plaines Wilhems: Le Pétrin, heathland NW of Pétrin Information Centre, on bark, 2019, Ertz 23318.

T. crassulum was described by Nylander (1859: 258) in the chapter 'Lichenes Insulae Borboniae', i.e. from Reunion. Later, this was inadvertently cited as 'Mauritius' (Dodge 1964: 93) or 'Mauritius ['Bourbon']' (Frisch 2006: 177). The former report from Mauritius is therefore erroneous. Our specimen has a mainly white thallus similar to the type specimen of Thelotrema crassulum described from Reunion.

olivaceum Fée [三 Thelotrema olivaceum (Fée) Mont.]. Reported from Mauritius by Daruty (1873).

NIGROVOTHELIUM Lücking, M. P. Nelsen \& Aptroot tropicum (Ach.) Lücking, M. P. Nelsen \& Aptroot [三 Verrucaria tropica Ach.]. 'Sur l'écorce des arbres, dans les forêts de la péninsule indienne et dans les bois de la Montagne-Noire à l'île Maurice' (Bélanger 1834) (PC 0019113).

\section{NORMANDINA Nyl.}

\section{pulchella (Borrer) Nyl.}

Rivière Noire: Trail from Plaine Champagne towards Piton de la Petite Rivière Noire, on bark, 2016, Diederich 18441. Savanne: Near Grand Bassin, on bark, 2019, obs. Ertz \& Diederich (no specimen).

Previously reported from Macchabee Forest, 1990, Hawksworth (K-IMI) by David \& Hawksworth (1995).

\section{NYUNGWEA Sérus., Eb. Fischer \& Killmann}

Nyungwea pyneei Ertz \& Diederich, sp. nov.

(Figs 4, 11)

MycoBank MB 834926

Diagnosis: A species of Nyungwea producing goniocysts on slightly convex cushions, without forming distinct stipes.

Type: Mauritius, Pamplemousses district, Pamplemousses, Sir Seewoosagur Ramgoolam Botanical Garden, $20.1063^{\circ} \mathrm{S}$, $57.5813^{\circ} \mathrm{E}$, alt. $80 \mathrm{~m}$, on bark of trees, 28 July 2016, Diederich 18265 (MAU - holotype, BR, LG, herb. Diederich - isotypes).

Description. Thallus corticolous, crustose, very thin and partly endophloeodal and intermingled with dead cells of bark, up to $40 \mu \mathrm{m}$ thick, continuous, white, I+ pale orange; 
hyphae hyaline, smooth, branched, without crystals, $1-2 \mu \mathrm{m}$ diam., I+ pale orange. Prothallus not seen, but the presence of a dark brown to black borderline $\sim 0.05-0.15 \mathrm{~mm}$ wide formed in contact with other lichens. Photobiont trentepohlioid; cells subspherical to \pm oblong-elongated, 5-12 $\times$ 4-7 $\mu \mathrm{m}$, sometimes densely filling a dead cell of the bark. Goniocyst-producing thallus cushions numerous, white to pale cream, becoming greenish just below the layer of goniocysts when abraded, rounded, without or with a slightly constricted base, $95-190 \mu \mathrm{m}$ diam, sometimes fused forming irregular patches of up to $1(-2) \mathrm{mm}$ diam, slightly raised above the level of the thallus, up to $160 \mu \mathrm{m}$ high when single and up to $280 \mu \mathrm{m}$ high when forming larger patches, containing numerous colourless crystals $1-7 \mu \mathrm{m}$ diam. dissolving in K. Hyphae forming cushions hyaline, richly branched, a few anastomosed, 1.5-2 $\mu \mathrm{m}$, I+ pale orange. Goniocysts numerous on upper surface of thallus cushions, dark brown when mature, formed of a single trentepohlioid algal cell (or rarely a couple of them) that is tightly embedded in a branched network of short dark brown hyphae, $8-10 \mu \mathrm{m}$ diam; these hyphae stay tightly on the algal cell without forming hairs and do not form any structure that could be
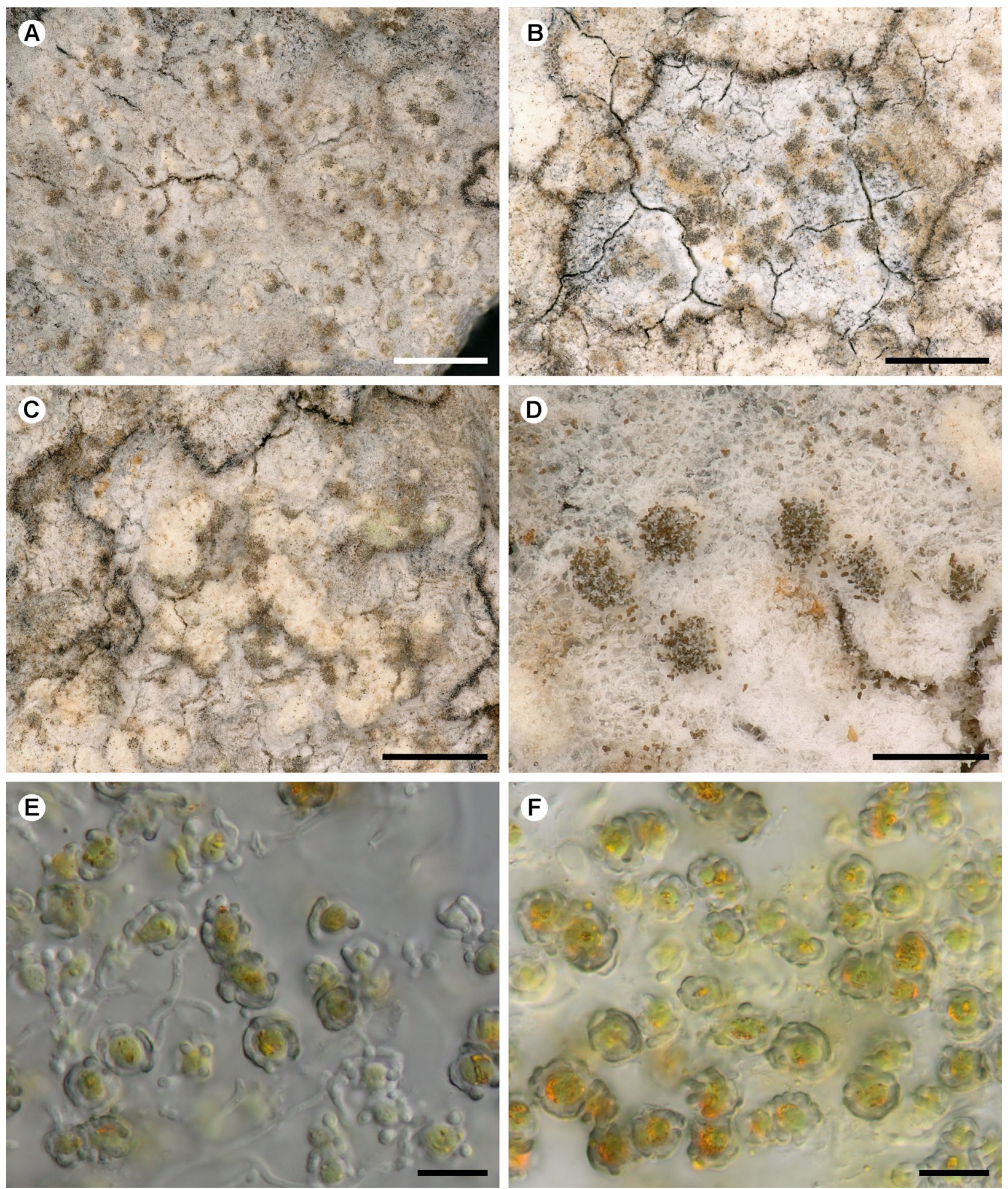

Figure 11. Nyungwea pyneei [A, C-F: holotype; B: Ertz 21450]. A-D - thallus with goniocyst-producing cushions; E-F - goniocysts in water. Scales: A-C $=1 \mathrm{~mm} ; \mathrm{D}=250 \mu \mathrm{m}$; E-F $=10 \mu \mathrm{m}$. Photos: D. Ertz. 
described as paraplectenchymatous or a cortex of isodiametric cells. Goniocysts easily detached from their thallus cushions and act as diaspores. Ascomata and conidiomata absent. Chemistry: thallus $\mathrm{K}-, \mathrm{C}-, \mathrm{P}-, \mathrm{UV}-$; goniocyst-producing thallus cushions $\mathrm{K}-, \mathrm{C}+$ red, $\mathrm{P}-$, $\mathrm{UV}-$; lecanoric acid detected by TLC (solvents B', EA).

Ecology and distribution. The species is only known from the Sir Seewoosagur Ramgoolam Botanical Garden in Mauritius, where it grows on the bark of trees, including Swietenia mahagoni.

Notes. The generic placement is confirmed by our phylogeny, where the new species groups with the generic type (Fig. 4). The new species is unique in having slightly convex goniocyst-producing thallus cushions. Nyungwea pallida Sérus., Eb. Fischer \& Killmann described from the mountains of East Africa differs by goniocysts producing on distinct stipes up to $1 \mathrm{~mm}$ long and by paler goniocysts (Sérusiaux et al. 2006).

Etymology. The new species is dedicated to Mauritian botanist Kersley Pynee, formerly working in The Mauritius Herbarium, now Technical Officer at the Ministry of Agro Industry and Food Security in Mauritius, to thank him for having guided us during several collecting trips in 2016.

Additional specimen examined. MAURITIUS. Same locality as the type, on bark of Swietenia mahagoni, 2016, Ertz 21450.

\section{OCELLULARIA G. Mey.}

bahiana (Ach.) Frisch [三 Thelotrema bahianum (Ach.) Ach.]. Reported from Mauritius by Daruty (1873).

bonplandii (Fée) Müll. Arg. [三 Thelotrema bonplandii Fée]. 'Sur l'écorce des arbres de la montagne du Pouce, à l'île Maurice' (PC0028108) (Bélanger 1834).

cavata (Ach.) Müll. Arg. [三 Thelotrema cavatum Ach.]. Reported from Mauritius by Daruty (1873).

\section{*mauritiana Hale}

Mycotaxon 3: 175 (1975). Type: Mauritius: Pouce, Ayres (BM, holotype; US, isotype) (Frisch \& Kalb 2006: 506-509).

Port Louis and Moka: Along trail from Moka to Le Pouce, on bark, 2019, Ertz 24061.

A pantropical species (Frisch \& Kalb 2006). Our specimen comes from the type locality (Le Pouce) and has slightly more septate ascospores, (3-)5-7-septate, than in the description by Frisch \& Kalb (2006; 3-5(-6)-septate).

\section{${ }^{*}$ petrinensis J. C. David}

in David \& Hawksworth, Biblioth. Lichenol. 57: 99 (1995). Type: Plaines Wilhems, Vacoas, Le Pétrin Nature Reserve, heathland, $640 \mathrm{~m}$, in cortice Sideroxyli puberuli, 11 June 1990, Hawksworth (K-IMI 400608, holotype) (David \& Hawksworth 1995; Crittenden et al. 1995).

Plaines Wilhems: Le Pétrin, heathland NW of Pétrin Information Centre, on bark, 2019, Ertz 23338; Curepipe, Curepipe Botanical Gardens, on bark, 2019, Ertz 24230; Curepipe, Trou aux Cerfs, along road surrounding the crater, on bark, 2019, Ertz 24260. Rivière Noire: Trail from Plaine Champagne towards Piton de la Petite Rivière Noire, on bark, 2019, Ertz 23993.

A pantropical species, also known from Australia (Lücking \& Pérez-Ortega 2015) and Venezuela (Kraichak et al. 2014).

\section{OCHROLECHIA A. Massal.}

\section{africana Vain.}

*=Lecanora parella var. phloeoleuca Nyl., in Crombie, Journ. Linn. Soc., Bot. 15: 440 (1876); E Ochrolechia parella f. phloeoleuca (Nyl.) Zahlbr., Cat. Lich. Univ. 5: 690 (192). Type: Rodrigues, on bark of trees (twigs), 1874, Balfour 2330 (H-NYL 3635, type?, verified by M. Kukwa 2006; H-NYL 23919).

Rivière Noire: Trail from Plaine Champagne towards Piton de la Petite Rivière Noire, on bark, 2016, Diederich 18675; Brise Fer Forest, on bark, 2019, Diederich 19221 (MAU). Specimen 18675 presents numerous young, immature apothecia, while in specimen 19221 all apothecia are old. Both are, however, well characterized by the white thallus with a rugose surface, a cortex not giving any positive reactions, and a medulla and a hymenium that are $\mathrm{C}+$ red (Brodo 1991). The species is new for the island of Mauritius.

pallescens (L.) A. Massal. [三Lecanora parella var. pallescens (L.) Ach.]. Reported from Mauritius by Daruty (1873).

\section{OPEGRAPHA Ach.}

angulosa Müll. Arg. = Opegrapha semiatra

atra Pers. var. abbreviata Flörke, see Arthonia atra

bonplandii Fée $\equiv$ Zwackhia bonplandii

dendritica Ach. $\equiv$ Phaeographis dendritica

*difficilior Nyl. ex Cromb.

Journ. of Bot. 14: 264 (1876). Type: Rodrigues, on decaying (decorticated) stumps of trees, 1874, Balfour 2251 (H-NYL 6802, lectotype, designated by Ertz 2009; BM, N-Nyl 6208, isolectotypes) (Crombie 1876a, b; Ertz 2009).

Moka: Réduit, close to Mauritius Herbarium building, on bark of Mangifera, 2019, Ertz 23246. Pamplemousses: Jardin Botanique, on bark of Mangifera, 2016, Ertz 21442, 21504; ibid., on bark, Ertz 21487, 21493; ibid., on bark of Terminalia, Ertz 21491.

The species is also known from Kenya and West Africa (Ertz 2009), and is here reported as new for the island of Mauritius.

duplicata (Ach.) Bél. $\equiv$ Graphis duplicata

\section{+foreaui (Moreau) Hafellner \& R. Sant.}

= Opegrapha trassii S. Y. Kondr. \& Coppins

Rivière Noire: Trail from Plaine Champagne towards Piton de la Petite Rivière Noire, on bark, on Heterodermia, 2019, Ertz 24041.

A lichenicolous fungus, previously reported from Mauritius, on Heterodermia obscurata, Ayres (E) by Coppins \& Kondratyuk (1998).

laubertiana (Fée) Bél. $\equiv$ Allographa laubertiana

poitaei (Fée) Bél. $\equiv$ Diorygma poitaei

rugulosa Fée $\equiv$ Graphis rugulosa

semiatra Müll. Arg.

*=Opegrapha angulosa Müll. Arg., Journ. Linn. Soc., Bot. 30: 457 (1895). Type: Mauritius, Pouce, 1894, Ayres (G 00047533, holotype) (Ertz 2009: 99).

Rivière Noire: Chamarel, Ebony Forest, around viewpoint, on bark, 2019, Ertz 23562. 
sordida (Fée) Mont. \& Bosch $\equiv$ Phaeographis sordida

trassii S. Y. Kondr. \& Coppins = Opegrapha foreaui

\section{OXYSTOMA Eschw.}

"friesianum Bél. [as 'Friesana'], Voyage aux Indes-orientales, pendant les années 1825-1829: 132 (1834). Type: 'Sur l'écorce des arbres, dans le quartier des Pampelmousses, à l'île Maurice', Bélanger (PC 0070012, G 00116393).

According to the type specimen (G00116393, photograph on JSTOR) the species might belong to the genus Celothelium.

\section{PANNARIA Delise ex Bory}

*cinerascens (Nyl.) P. M. Jørg.

Biblioth. Lichenol. 88: 241 (2004); 三 Pannaria rubiginosa f. cinerascens Nyl., in Crombie, Bot. J. Linn. Soc. 15: 436 (1876). Type: Rodrigues, on rocks, 1874, Balfour 2321 (BM, lectotype, selected by Jørgensen 2004).

Also reported from the forested mountainside between Yemen and Mt Brise Fer, 1991, Krog \& Timdal (O) by Jørgensen (2004: 242).

luridula Nyl. ex Cromb. = Lepidocollema marianum

* macrocarpa Müll. Arg.

Hedwigia 31: 277 (1892). Type: 'In ins. Mauritii cum Psoromate sphinctrino, corticola', Ayres (G 00047528, K).

Further unpublished specimens from Le Pouce, Mt Cocotte and Piton de la Petite Rivière Noire, collected by Krog \& Timdal in 1991, are kept in O.

multifida P. M. Jørg.

Reported from Piton de la Petite Rivière Noire, Macchabee Forest (0.5-1 km ESE of Macchabee Kiosk) and along the road between Mt Cocotte and Bassin Blanc, 1991, Krog \& Timdal (O) (Jørgensen 2004: 241; Lücking \& Timdal 2016: 194; all det. Jørgensen 2002). Further unpublished specimens from Le Pouce and Mt Cocotte, collected by Krog \& Timdal in 1991 and identified by Jørgensen in 2002, are kept in $\mathrm{O}$.

pannosa Nyl. $\equiv$ Parmeliella pannosa

\section{"pruinosa P. M. Jørg. \& Timdal}

Biblioth. Lichenol. 88: 242 (2004). Type: Savanne, Mt Cocotte, along path towards the peak, 11 Nov. 1991, Krog \& Timdal MAU 32/56 (O L-21609, holotype).

Also reported from Piton de la Petite Rivière Noire, Le Pouce and Mt Cocotte, 1991, Krog \& Timdal (O) by Jørgensen (2004).

\section{ramosii Vain.}

Reported from the road between Mt Cocotte and Bassin Blanc, 1991, Krog \& Timdal (O) by Lücking \& Timdal (2016: 194). Further unpublished specimens from Piton de la Petite Rivière Noire, Macchabee Forest, Mt des Créoles, Le Pouce, Pétrin and Mt Cocotte, collected by Krog \& Timdal in 1991 and some identified by Jørgensen in 2002, are kept in $\mathrm{O}$.

rubiginosa (Thunb.) Delise. Reported from Mauritius by Lindau (1908).

rubiginosa f. cinerascens Nyl. $\equiv$ Pannaria cinerascens rubiginosa var. dispartita Nyl., see Lepidocollema brisbanense

\section{santessonii Swinscow \& Krog}

Reported from the viewpoint WNW of Mt Cocotte, 1991, Krog \& Timdal (O) by Lücking \& Timdal (2016: 194). Further unpublished specimens from Pétrin and Mt Cocotte, collected by Krog \& Timdal in 1991, are kept in O.

sphinctrina (Mont.) Hue [ $\equiv$ Psoroma sphinctrinum (Mont.) Nyl.]. Reported from the road between Mt Cocotte and Bassin Blanc, 1991, Krog \& Timdal (O) by Lücking \& Timdal (2016: 194); also from Mauritius by Daruty (1873) and Nylander (1859: 256). Reports of this species should be revised, as most Mauritius herbarium specimens named $P$. sphinctrina in the past proved to represent species of Gibbosporina (Elvebakk et al. 2016).

\section{PARACARPIDIUM Müll. Arg.}

johnstoni Müll. Arg. $\equiv$ Endocarpon johnstonii

\section{PARMELIA Ach.}

*afromontana Parnell, J. Trop. Ecol. 5: 374 (1989), nom. nud. (description missing). Original material: Ile aux Aigrettes, on Maytenus pyria, Parnell et al. (1989), BM, det. James.

appendiculata Fée $\equiv$ Parmotrema appendiculatum

atrichoides Nyl. Rodrigues, on rocks, 1874, Balfour 2227 (Crombie 1876b).

caperata (L.) Ach. $\equiv$ Flavoparmelia caperata

caraccensis f. isidiosa Müll. Arg. = Hypotrachyna microblasta conspersa (Ehrh. ex Ach.) Ach. $\equiv$ Xanthoparmelia conspersa crenulata Hook. f. $\equiv$ Lobariella crenulata cristifera Tayl. $\equiv$ Parmotrema cristiferum

*darutyi Wedd., in Daruty, Trans. Roy. Soc. Arts Mauritius, n.s. 7: 165 (1873), nom. nud. (description missing).

decorata $($ Hue) Dodge $=$ Parmotrema reticulatum glomulifera (Lightf.) Ach. = Ricasolia amplissima

hildenbrandtii Kremp. Reported from Rodrigues, 1874, Balfour (K) by Dodge (1959: 150).

imerinensis Dodge $=$ Parmotrema cristiferum

latissima Fée $\equiv$ Parmotrema latissimum

limbata Laurer $\equiv$ Relicina limbata

mauritiana Gyeln. = Hypotrachyna microblasta

meiosperma (Hue) Dodge. Reported from Mauritius, on the Bruce, on trees, Ayres (K), and Pouce, Ayres (K, several specimens) by Dodge (1959: 140), and from Rodrigues, 1874, Balfour 2249 (K) by Dodge (1959: 140).

microblasta Vain. $\equiv$ Hypotrachyna microblasta

olivetorum $\mathrm{Nyl} . \equiv$ Cetrelia olivetorum

ornata (Hue) Dodge $=$ Parmotrema reticulatum

pannosa (Sw.) Sw. $\equiv$ Parmeliella pannosa

perforata (Wulfen) Ach. $\equiv$ Parmotrema perforatum

perlata (Huds.) Ach. $\equiv$ Parmotrema perlatum

perlata var. ciliata (DC.) Duby. Reported from Mauritius by Daruty (1873). Almost surely belongs to Parmotrema. 
pulverulenta (Schreb.) Ach. $=$ Physconia distorta

punicea (Sw.) Ach. $\equiv$ Haematomma puniceum

quercizans var. denudata Laurer $=$ Ricasolia sublaevis

saccatiloba Taylor $\equiv$ Parmotrema saccatilobum

sieberi Dodge $=$ Parmotrema dilatatum

sorediifera (Fée) Bél. $\equiv$ Lecanora sorediifera

subconspersa Nyl. $\equiv$ Xanthoparmelia subconspersa

subfuscescens Nyl. $\equiv$ Xanthoparmelia subfuscescens

subhypoclysta Dodge $=$ Xanthoparmelia subramigera

*viridula Wedd., in Daruty, Trans. Roy. Soc. Arts Mauritius, n.s.

7: 165 (1873), nom. nud. (description missing).

wightii Dodge $=$ Xanthoparmelia phaeophana

zeyheri Dodge, see under Xanthoparmelia

\section{PARMELIELLA Müll. Arg.}

\section{endoferruginea Aptroot}

Reported from the road between Mt Cocotte and Bassin Blanc, 1991, Krog \& Timdal (O) by Lücking \& Timdal (2016: 194).

mariana (Fr.) P. M. Jørg. \& D. J. Galloway $\equiv$ Lepidocollema marianum

pannosa (Sw.) Müll. Arg. [三 Pannaria pannosa Nyl.]. Reported from Mauritius by Daruty (1873) and Lindau (1908), and 'Sur les arbres, dans les lieux humides des forêts, aux îles Maurice et de Bourbon' by Bélanger (1834).

papillata P. M. Jørg. $\equiv$ Lepidocollema papillatum

stylophora (Vainio) P. M. Jørg. 三 Lepidocollema stylophorum

\section{PARMOTREMA A. Massal.}

acrotrychum (Kurok.) Streimann

Plaines Wilhems: Le Pétrin, between Pétrin Information Centre and first viewpoint along trail to the west, on bark, 2016, Diederich 18332 (det. Masson; TLC: atranorin, protolichesterinic, fumarprotocetraric, succinprotocetraric).

New for Mauritius.

appendiculatum (Fée) Hale [三 Parmelia appendiculata Fée]. Reported from Mauritius (FH: herb. Tuckerman sub P. perlata var. ciliata) by Dodge (1959: 171).

\section{crinitum (Ach.) Choisy}

Reported from Mauritius by Crittenden et al. (1995, as Parmotrema cf. crinitum). Other unpublished specimens from Le Pouce and Curepipe (Trou aux Cerfs), collected in 1991 by Krog \& Timdal, are kept in O. A further specimen named Parmelia crinita and collected in 1802 by Bory de Saint-Vincent 'sur les grands arbres' at Le Pouce is kept in PC (PC 0009140).

\section{cristiferum (Taylor) Hale}

$\equiv$ Parmelia cristifera Taylor; = Parmelia imerinensis Dodge Reported from Mauritius, Wright (BM, FH-00259715) by Hale (1965: 243) and Krog \& Swinscow (1981: 174), Robillard (M, US) by Hale (1965: 243), Réduit, Orian 7 (K) by Dodge (1959: 143-144), and from Ile aux Aigrettes (BM, det. James) by Parnell et al. (1989). dilatatum (Vain.) Hale

$\equiv$ Parmelia dilatata Vain.

*= Parmelia sieberi C. W. Dodge, Ann. Missouri Bot. Gard. 46: 148 (1959). Type: Mauritius, corticole, Sieber, Crypt. Exot. 44 (FH-00259711) (Dodge 1959: 117, 148-149; Hale 1965: 245).

Plaines Wilhems: Curepipe, Curepipe Botanic Gardens, on bark, 2016, Diederich 18308 (det. Masson; TLC: atranorin, usnic, protocetraric, echinocarpic).

Previously also reported from Mauritius, Robillard (FH, sub Parmelia cristifera), Wight (FH-Tayl, sub Parmelia cristifera) and Pouce, Ayres (K) by Dodge (1959: 149).

latissimum (Fée) Hale [三 Parmelia latissima Fée]. Reported from Rodrigues, on trees and rocks, 1874, Balfour 2249, 2205 by Crombie (1876b).

perforatum (Wulfen) A. Massal. [三 Parmelia perforata (Wulfen) Ach.]. Reported from Mauritius by Daruty (1873).

perlatum (Huds.) M. Choisy [三 Parmelia perlata (Huds.) Ach.]. Reported from Mauritius by Laurer (1827).

\section{reticulatum (Taylor) M. Choisy}

$\equiv$ Rimelia reticulata (Taylor) Hale \& Fletcher; = Parmelia decorata (Hue) Dodge; = Parmelia ornata (Hue) Dodge

Rivière Noire: Chamarel, Ebony Forest, around viewpoint, on bark, 2016, Diederich 18544 [det. Masson; TLC: atranorin, salazinic (major), consalazinic (minor)].

Previously also reported from Mauritius by Crittenden et al. (1995), Moka, below Mt Ory, on shaded volcanic rocks by a track, 1990, Hawksworth (K-IMI) by David \& Hawksworth (1995), Pamplemousses Botanical Garden, on bark, 1990, Hawksworth (K-IMI) by David \& Hawksworth (1995), and Grand Port, Mt des Créoles, 1991, Krog \& Timdal (O) by Lücking \& Timdal (2016: 198). Also, as $P$. ornata, from Mauritius, Wight (FH-Tayl, glued to sheet with $P$. cristifera Tayl.), and Bojer (K: herb Hooker) (Dodge 1959: 98), and as P. decorata from Robillard (FH, sub P. perlata var. olivetorum Nyl., det. Müll. Arg.) by Dodge (1959: 96). Further unpublished specimens from Mt Corps de Garde, Macchabee Forest, Riche en Eau, Ile aux Aigrettes, Réduit, Le Pouce and Henrietta, collected by Krog \& Timdal in 1991, are kept in O.

saccatilobum (Taylor) Hale $=$ Parmotrema tinctorum

subcorallinum (Hale) Hale

$\equiv$ Parmelia subcorallina Hale

Reported from Mauritius, Robillard (G) by Hale (1962, 1965: 310). A further unpublished specimen from Pétrin heath, collected by Krog \& Timdal in 1991, is kept in O.

\section{subisidiosum (Müll. Arg.) Hale}

Rivière Noire: Trail from Plaine Champagne towards Piton de la Petite Rivière Noire, on bark, 2016, Diederich 18464 [det. Masson; TLC: atranorin, salazinic (major), consalazinic (minor)].

A further specimen from Le Pouce, collected by Krog \& Timdal in 1991, is kept in O. New for Mauritius.

tinctorum (Delise ex Nyl.) Hale agg.

= Parmelia saccatiloba Taylor; $\equiv$ Parmotrema saccatilobum (Taylor) Hale

Pamplemousses: Jardin Botanique, on bark, 2016, Diederich 18233, 18266, Ertz 21476. Rivière Noire: Chamarel, Ebony Forest, around viewpoint, on bark, 2016, Diederich 
18543; trail from Plaine Champagne towards Piton de la Petite Rivière Noire, on bark, 2016, Diederich 18451. Plaines Wilhems: Curepipe, Curepipe Botanic Gardens, on bark, 2016, Diederich 18299, 18595 (all det. Masson, except Ertz 21476; TLC (all Diederich, except 18595): atranorin, lecanoric).

Also reported from Mauritius by Hale (1965: 262), from Grand Port, Mt des Créoles, 1991, Krog \& Timdal (O) and Grand Port, Bambou Mountains, 1991, Krog \& Timdal (O) by Lücking \& Timdal (2016: 192, 198), from Pamplemousses Botanical Garden, 1990, Hawksworth (K-IMI) by David \& Hawksworth (1995), and from Mauritius by Crittenden et al. (1995, as Parmotrema cf. tinctorum). Further unpublished specimens from Piton de la Petite Rivière Noire, Morne Brabant, Macchabee Forest, between Yemen and Mt Brise Fer, Mt Corps de Garde, Baie du Cap, Flacq, Riche en Eau, Réduit, Le Pouce, Pamplemousses Botanical Garden, Curepipe (Trou aux Cerfs), Henrietta, Tamarin Falls and Mt Cocotte, collected by Krog \& Timdal in 1991, are kept in O.

zollingeri (Hepp) Hale

$\equiv$ Parmelia zollingeri Hepp

Reported from Mauritius, McGregor s.n. (BM) by Hale (1965: 268).

PELTIDEA Ach.

floerkeana Laurer $=$ Coccocarpia erythroxyli

\section{PELTULA Nyl.}

\section{*rodriguesii (Cromb.) Büdel}

Lichenologist 21: 293 (1989); 三 Heppia rodriguesii Cromb., J. Bot. 14: 263 (1876). Type: Rodrigues, on rocks, 1874, Balfour 2302 (BM, lectotype, selected by Büdel 1989); Balfour 2233 (BM, isolectotype) (Büdel 1987, 1989; Crombie 1876a, b).

The species is widespread and further known from Italy, Cape Verde Islands, South Africa, Zimbabwe and Australia (Büdel 1989).

\section{PERTUSARIA DC.}

cicatricosa Müll. Arg.

*= Pertusaria subtruncata Müll. Arg., Flora 67: 397 (1884). Type: Mauritius, 1876, Robillard (G 00066427, holotype) (Archer 1997: 51).

communis DC. $=$ Pertusaria pertusa

communis var. minor Müll. Arg. $\equiv$ Pertusaria pertusa var. minor

\section{*hymenelioides J. C. David}

in David \& Hawksworth, Biblioth. Lichenol. 57: 101 (1995). Type: Moka, sub monte Ory, in petris vulcanicis secundum viam, 12 June 1990, Hawksworth (K-IMI 400639, holotype) (David \& Hawksworth 1995; Crittenden et al. 1995).

*impallescens Nyl. ex Cromb.

J. Bot. 14: 264 (1876). Type: Rodrigues, on rocks, 1874, Balfour 2214 (Crombie 1876a, b).

This poorly known species is accepted by Archer (1997: 164) and keyed out by Archer \& Elix (2018).

leioplaca DC. Reported from Mauritius by Daruty (1873).

margaritifera Zahlbr. Reported from Mauritius by Daruty (1873).

\section{*muricata J. C. David}

in David \& Hawksworth, Biblioth. Lichenol. 57: 102 (1995). Type: Plaines Wilhems, Vacoas, Le Pétrin Nature Reserve, in cortice, 11 June 1990, Hawksworth (K-IMI 400607, holotype) (Archer 1997: 111; David \& Hawksworth 1995; Crittenden et al. 1995).

Plaines Wilhems: Le Pétrin, heathland NW of Pétrin Information Centre, on bark, 2019, Ertz 23365 (TLC: constictic, stictic and trace of norstictic, solvent A).

pertusa (L.) Tuck. [= Pertusaria communis DC. (illeg., nom. superfl.)]. Reported from Mauritius by Daruty (1873), and from Flacq, near Mare La Chaux village, on bark of Delonix regia, 1990, Hawksworth (K-IMI 400600) by Crittenden et al. (1995).

"pertusa var. minor (Müll. Arg.) Zahlbr., Cat. Lich. Univ. 5: 201 (1928); 三 Pertusaria communis var. minor Müll. Arg., Lichenol. Beitr. VI, Flora 60: 478 (1877). Type: Mauritius, Robillard. Also reported from Mauritius by Dodge (1964: 253).

\section{*pertusella Müll. Arg.}

Flora 67: 283 (1884). Type: Mauritius, 1876, Robillard (G 00295201, holotype) (Archer 1997: 124).

A rare Paleotropical species.

subtruncata Müll. Arg. = Pertusaria cicatricosa

trypetheliiformis Nyl. Reported from Mauritius by Daruty (1873).

velata (Turn.) Nyl. $\equiv$ Varicellaria velata

\section{PHAEOGRAPHINA Müll. Arg.}

heterospora (Nyl.) Zahlbr. $\equiv$ Sarcographina heterospora

\section{PHAEOGRAPHIS Müll. Arg.}

"aequabilis (Wedd. ex Nyl.) Zahlbr., Cat. Lich. Univ. 2: 364 (1923); E Graphis aequabilis Wedd. ex Nyl., Bull. Soc. Linn. Normandie, sér. 2, 7: 175 (1874 ['1873’]); 三 G. aequabilis Wedd., in Daruty, Trans. Roy. Soc. Arts Mauritius, n.s. 7: 164 (1873), nom. nud. Type: Mauritius, corticolous (H 9507963)

dendritica (Ach.) Müll. Arg. [三 Opegrapha dendritica Ach.]. 'Sur l'écorce des arbres, à l'île Maurice' (Bélanger 1834).

\section{intricans (Nyl.) Staiger}

Pamplemousses: Jardin Botanique, on bark of Ptychosperma macarthurii, 2016, Ertz 21452 (sub. Melaspilea $\mathrm{cf}$. lekae)

New for Mauritius.

"medusuliza Müll. Arg., J. Linn. Soc., Bot. 30: 461 (1895). Type: 'Corticola, in ins. Mauritii', Balfour (G-00047651). Although the annotation of the specimen and the original publication say that the specimen was collected in Mauritius, it almost surely originates from Rodrigues, where Balfour made extensive collections in 1874 .

scalpturata (Ach.) Staiger [三 Graphis scalpturata Ach.]. Reported from Rodrigues, on branches of trees, 1874, Balfour 2365 (Crombie 1876b).

sordida (Fée) Müll. Arg. [三 Opegrapha sordida (Fée) Mont. $\&$ Bosch]. 'Sur l'écorce des arbres, à l'île Maurice" (Bélanger 1834). 


\section{PHAEOPHYSCIA Moberg}

hispidula (Ach.) Essl. [= Physcia setosa (Ach.) Nyl.]. Reported from Mauritius, 'auf Rinde' by Lindau (1908).

\section{PHYLLOCHARIS Fée}

elegans Fée $=$ Strigula smaragdula

\section{PHYLLOPELTULA Kalb}

corticola (Büdel \& R. Sant.) Kalb

Pamplemousses: Jardin Botanique, on bark, 2016, Diederich 18583, Ertz 21498. Rivière Noire: La Preneuse (between Tamarin and Grande Rivière Noire), cemetery, on bark at the base of a tree, 2016, Diederich 18384.

New for Mauritius.

PHYLLOPSORA Müll. Arg., nom. cons. prop.

\section{africana Timdal \& Krog}

Reported from Piton de la Petite Rivière Noire, 1991, by Timdal \& Krog (2001).

albicans Müll. Arg. The report of this species from Mauritius by Timdal \& Krog (2001) refers to P. porphyromelaena.

\section{borbonica Timdal \& Krog}

Rivière Noire: Trail from Plaine Champagne towards Piton de la Petite Rivière Noire, on bark, 2019, Ertz 23952.

Also reported from Macchabee Forest (0.5-1 km ESE of Macchabee Kiosk), 1991, by Timdal \& Krog (2001).

Kistenich et al. (2018) showed that this species belongs to Sporacestra A. Massal, but no new combination has been published yet.

\section{breviuscula (Nyl.) Müll. Arg.}

Reported from Macchabee Forest (along path to Mt Brise Fer) and Bambou Mountains (0.5-1 km NNE of Piton Rouge), 1991, by Timdal \& Krog (2001).

\section{buettneri (Müll. Arg.) Zahlbr.}

Rivière Noire: Trail from Plaine Champagne towards Piton de la Petite Rivière Noire, on bark, 2019, Ertz 23929 (TLC: pannarin and zeorin, solvent A).

Also reported from Piton de la Petite Rivière Noire, Macchabee Forest (along path to Mt Brise Fer) and Macchabee Forest (0.5-1 km ESE of Macchabee Kiosk), 1991, by Timdal \& Krog (2001), and from the road between Mt Cocotte and Bassin Blanc, 1991, by Lücking \& Timdal (2016: 194).

\section{castaneocincta (Hue) Kistenich \& Timdal}

Rivière Noire: East of Black River, from Visitor's Centre to Pilgrims Trail, on bark, 2016, Diederich 18494 (det. Timdal).

New for Mauritius.

\section{chlorophaea (Müll. Arg.) Müll. Arg.}

Rivière Noire: Trail from Plaine Champagne towards Piton de la Petite Rivière Noire, on bark, 2016, Diederich 18416 (det. Timdal); ibid., 2019, Ertz 23961 (TLC: furfuracein, solvent A), 23963 (TLC: furfuracein, solvent A).

Also reported from Piton de la Petite Rivière Noire, Le Pouce and Mt Cocotte, 1991, by Timdal \& Krog (2001).

compacta (Nyl.) Gotth. =? Phyllopsora mauritiana

\section{confusa Swinscow \& Krog}

Port Louis and Moka: Along trail from Moka to Le Pouce, on rock, 2019, Ertz 24100 (TLC: no substance detected, solvent A). Rivière Noire: Chamarel, Ebony Forest, along trail W of viewpoint, on rock, 2019, Ertz 23594 (TLC: no substance detected, solvent A).

Also reported from Piton de la Petite Rivière Noire and Macchabee Forest (0.5-1 km ESE of Macchabee Kiosk), 1991, by Timdal \& Krog (2001), and from the road between Mt Cocotte and Bassin Blanc, 1991, by Lücking \& Timdal (2016: 194).

\section{*dolichospora Timdal \& Krog}

Mycotaxon 77: 76 (2001). Type: Mauritius, Plaine Wilhems, Macchabee Forest, $0.5-1 \mathrm{~km}$ ESE of Macchabee kiosk, 1991, Krog \& Timdal MAU65/22 (O L22197, holotype; CANB, isotype [Elix 2008]]).

Rivière Noire: Trail from Plaine Champagne towards Piton de la Petite Rivière Noire, on bark, 2019, Ertz 23918, 23962 (TLC of both specimens: furfuracein and two unknown of higher Rf).

Also reported from Piton de la Petite Rivière Noire, 1991, by Timdal \& Krog (2001).

gossypina (Sw.) Kistenich, Timdal, Bendiksby \& S. Ekman [三 Crocynia gossypina (Sw.) A. Massal.]. Reported from Mauritius by Hue (1892: 182).

\section{*mauritiana (Taylor) Swinscow \& Krog}

Lichenologist 13: 242 (1981); 三Lecidea mauritiana Taylor, London J. Bot. 6: 151 (1847). Type: Mauritius, on bark (FH, lectotype, designated by Swinscow \& Krog 1981; G 00127487).

*=? Lecidea compacta Nyl., Ann. Sci. Nat., Bot., sér. 4, 11: 259 (1859); 三 Phyllopsora compacta (Nyl.) Gotth. Schneid., Biblioth. Lichenol. 13: 175 (1979). Type: Mauritius (H-NYL 20654) (Swinscow \& Krog 1981). Probably a synonym of Phyllopsora mauritiana, fide Swinscow \& Krog (1981: 240).

Rivière Noire: Brise Fer Forest, on bark, 2019, Ertz 24291, 24302.

Also reported from Piton de la Petite Rivière Noire and Macchabee Forest (along path to Mt Brise Fer), 1991, by Timdal \& Krog (2001), Kistenich et al. (2018: 903) and Kistenich et al. (2019a).

\section{mediocris Swinscow \& Krog}

Rivière Noire: Trail from Plaine Champagne towards Piton de la Petite Rivière Noire, on bark, 2016, Diederich 18396, 18571; Chamarel, Ebony Forest, around viewpoint, on bark, 2016, Diederich 18534, 18573 (Kistenich et al. 2019b).

Also reported from Macchabee Forest (0.5-1 km ESE of Macchabee Kiosk) and along the Bois Chéri-Grand Bassin road, at the bridge over Rivière des Anguilles, 1991, by Timdal \& Krog (2001).

\section{Crocynia molliuscula (Nyl.) Nyl.}

三Byssocaulon molliusculum $\mathrm{Nyl}$.].

Reported from Mauritius, ad saxa, herb. Fée by Nylander (1859: 259), and from the road between Mt Cocotte and Bassin Blanc, 1991, by Lücking \& Timdal (2016: 194) and Kistenich et al. (2019a). Further unpublished specimens from Piton de la Petite Rivière Noire and Macchabee Forest, collected by Krog \& Timdal in 1991, are kept in O. 
The generic type Crocynia gossypina was recently shown to be nested within the Phyllopsora clade and consequently was combined there (Kistenich et al. 2018). Crocynia molliuscula also belongs to Phyllopsora (Kistenich et al. 2019a) and is genetically so close to $C$. gossypina that the authors did not propose a new combination, awaiting further taxonomic studies of this group.

\section{porphyromelaena (Vain.) Zahlbr.}

Savanne: Along trail to Mt Cocotte, on bark, 2019, Ertz 23497, 23516 (TLC of both specimens: argopsin and norargopsin, solvent A).

Previously reported from Piton de la Petite Rivière Noire, Macchabee Forest (0.5-1 km ESE of Macchabee Kiosk), Mt Cocotte (along path towards peak), along the road between Mt Cocotte and Bassin Blanc, and Mt Cocotte (NW of the peak), 1991, by Timdal \& Krog (2001, sub P. albicans), and from the road between Mt Cocotte and Bassin Blanc, 1991, by Lücking \& Timdal (2016: 194).

\section{*swinscowii Timdal \& Krog}

Mycotaxon 77: 88 (2001). Type: Mauritius, Black River, along the path from Plaine Champagne towards Piton de la Petite Rivière Noire, 1991, Krog \& Timdal MAU9/50 (O L21220, holotype) (phylogeny: Kistenich et al. 2019a). Also reported from Le Pouce and from the road between Mt Cocotte and Bassin Blanc, 1991, by Timdal \& Krog (2001) and Lücking \& Timdal (2016: 194).

PHYSCIA (Schreb.) Michx.

aegialita (Afzel ex Ach.) Nyl. $\equiv$ Dirinaria aegialita

flavicans f. crocea (Ach.) Cromb. $=$ Teloschistes flavicans

obscura (Ehrh.) Hampe ex Fürnr. Reported from Mauritius by Daruty (1873).

picta (Sw.) Nyl. $\equiv$ Dirinaria picta

pulverulenta (Schreb.) Hampe ex Fürnr. = Physconia distorta pulverulenta var. muscigena (Ach.) Nyl. $\equiv$ Physconia muscigena setosa (Ach.) Nyl. = Phaeophyscia hispidula

speciosa (Wulfen) Nyl. $\equiv$ Heterodermia speciosa

\section{PHYSCIDIA Tuck.}

wrightii (Tuck.) Tuck.

Reported from Macchabee Forest, 1991, Krog \& Timdal (O, MAU) by Kistenich et al. (2018: 903).

\section{PHYSCONIA Poelt}

distorta (With.) J. R. Laundon [= Parmelia pulverulenta (Schreb.) Ach.; झ Physcia pulverulenta (Schreb.) Hampe ex Fürnr.]. Reported from Mauritius by Lindau (1908), and 'Sur l'écorce des arbres, à l'île Maurice' (Bélanger 1834).

muscigena (Ach.) Poelt [ $\equiv$ Physcia pulverulenta var. muscigena (Ach.) Nyl.]. Reported from Mauritius by Daruty (1873).

\section{PHYSMA A. Massal.}

byrsaeum (Ach.) Müll. Arg.

Plaines Wilhems: Curepipe, Curepipe Botanic Gardens, on bark, 2016, Diederich 18311 (dupl. LG); Le Pétrin, between Pétrin Information Centre and first viewpoint along trail to the west, on bark, 2016, Diederich 18357. Rivière Noire: Trail from Plaine Champagne towards Piton de la
Petite Rivière Noire, on bark, 2016, Diederich 18402 (dupl. LG), 18436 (dupl. LG); ibid., 2019, Ertz 23916; Chamarel, Ebony Forest, along trail W of viewpoint, on bark, 2019, Diederich 18949; Brise Fer Forest, on bark, 2019, Diederich 19243. Savanne: Along trail to Mt Cocotte, on bark, 2019, Diederich 18879.

Previously reported from Mt des Créoles, 1991, Krog \& Timdal (O) by Lücking \& Timdal (2016: 198) and Macchabee Forest, 1990, Hawksworth (K-IMI) Crittenden et al. (1995, as 'P. byrsaceum'). Further unpublished specimens from Piton de la Petite Rivière Noire, Pétrin heath and Mt Cocotte, collected by Krog \& Timdal in 1991, are kept in $\mathrm{O}$.

byrsinum (Ach.) Müll. Arg. [三 Collema byrsinum Ach.]. Reported from Mauritius by Daruty (1873).

\section{PICCOLIA A. Massal.}

\section{wrightii (Tuck.) Hafellner}

Rivière Noire: Trail from Plaine Champagne towards Piton de la Petite Rivière Noire, on bark, 2016, Diederich 18417.

New for Mauritius.

PLACODIUM Weber ex F. H. Wigg.

murorum DC. $=$ Caloplaca saxicola

\section{POLYMERIDIUM (Müll. Arg.) R. C. Harris}

\section{quinqueseptatum (Nyl.) R. C. Harris}

Plaines Wilhems: Curepipe, Trou aux Cerfs, along road surrounding the crater, on bark, 2016, Diederich 18283; Curepipe, Curepipe Botanic Gardens, on bark, 2016, Diederich 18307; ibid., 2019, Diederich 19103, 19105, 19173 \& Ertz 24245, 24232; Le Pétrin, heathland NW of Pétrin Information Centre, on bark, 2019, Ertz 23366. Rivière Noire: Brise Fer Forest, on bark, 2019, Diederich 19209.

The ascospores of $P$. quinqueseptatum are (4-)5(-7)-septate, 18-28 $\times$ 4-7 $\mu \mathrm{m}$, following Aptroot \& Lücking (2016), respectively (4-)5-7(-8)-septate, 18-22.5-27 × 4-5.5-7 $\mu \mathrm{m}$, following Harris (1990). Those of the similar P. pleiomerellum are 7-11-septate, 25-36 $\times 5-9 \mu \mathrm{m}$ (Aptroot \& Lücking 2016), respectively (5-)7-9(-10)-septate, 24 $32.3-40 \times 5.5-7-8.5 \mu \mathrm{m}$ (Harris 1990). Our specimens have $5-7(-8)$-septate ascospores, mainly $22-33 \times 7-8 \mu \mathrm{m}$, and some are intermediate between the published descriptions of the two species. We call our material $P$. quinqueseptatum, as this species was known from Africa (Angola, Mozambique) and the Indian Ocean (Seychelles), while P. pleiomerellum is known only from America and Papua New Guinea (Aptroot \& Lücking 2016). New for Mauritius.

\section{PORINA Müll. Arg.}

americana Fée. Reported from Mauritius by Crittenden et al. (1995, as Porina cf. americana).

chlorotica (Ach.) Müll. Arg. [三Verrucaria chlorotica Ach.]. Reported from Rodrigues, on rocks, 1874, Balfour 2282, by Crombie (1876b).

\section{epiphylla (Fée) Fée}

Reported from Mauritius, on Acrostichum obductum (S F74625) by Santesson (1952: 238). 
Porina florensii Diederich \& Ertz, sp. nov. (Figs 12-13) MycoBank MB 834927

Diagnosis: Characterized by a smooth to slightly rugulose thallus, perithecia immersed in 1-2 $\mathrm{mm}$ diam. convex, poorly delimited verrucae, a black ostiole, and large, mainly 10-14-septate ascospores, $\sim 93-111 \times 11.5-13.5 \mu \mathrm{m}$, with a very thick perispore, laterally $\sim 5-7 \mu \mathrm{m}$, apically $\sim 9-18 \mu \mathrm{m}$ thick.

Type: Mauritius, Rivière Noire: Black River Gorges National Park, trail from Plaine Champagne towards Piton de la Petite Rivière Noire, $20.4212^{\circ} \mathrm{S}( \pm 200 \mathrm{~m}), 57.4195^{\circ} \mathrm{E}$ $( \pm 700 \mathrm{~m})$, alt. $630-700 \mathrm{~m}$, on bark of trees, 5 Aug. 2016, Diederich 18453 (MAU - holotype, BR, herb. Diederich - isotypes).

Description. Thallus corticate, smooth to slightly rugulose, continuous, thin, pale olivaceous grey or green, sometimes with a narrow blackish prothallus; isidia and soralia absent. Photobiont Trentepohlia. Ascomata perithecioid, simple, dispersed, semiglobose, immersed, in $\sim 1-2 \mathrm{~mm}$ diam. convex, poorly delimited verrucae, covered by a thin thallus layer, except around the ostiole; ostiole apical, blackish; wall not carbonized. Hamathecium hyaline, not inspersed, of thin, simple, 1-1.5 $\mu \mathrm{m}$ diam. paraphyses. Asci cylindrical-clavate, I-, 290-300 × 36-47 $\mu \mathrm{m}$ $(\mathrm{n}=3), 8$-spored. Ascospores hyaline, I-, transversally mostly (8-)10-14(-15)-euseptate, fusiform, surrounded by a thick gelatinous sheath (perispore); measurements in water without perispore: $(86-) 93.4-110.6(-120) \times$ (10.5-)11.6-13.4(-14) $\mu \mathrm{m}$, ratio L/B (6.8-)7.3-9.1(-10.1); with perispore: $(110-) 118.1-139.4(-153) \times(21-) 22.6-$ 26.1(-26.8) $\mu \mathrm{m}$, ratio $(4.8-) 4.9-5.7(-6.0)$; perispore thickness laterally: $(4.8-) 5.2-6.7(-7.7) \mu \mathrm{m}$; perispore apically (6-)8.8-17.9(-25.8) $\mu \mathrm{m}(\mathrm{n}=20)$. Pycnidia not observed. Chemistry: thallus $\mathrm{K}+$ reddish brown, $\mathrm{C}-, \mathrm{KC}-$, $\mathrm{P}-$, UV-. No substances detected by TLC in specimen 18453 (solvent A).

Ecology and distribution. The species is known from five localities in Mauritius, where it is rather abundant and grows on trees of parks and in well-preserved forest.

Notes. Amongst the similar Australian corticolous taxa keyed out by McCarthy (2001), two species have more than 7-septate ascospores: Porina bellendenica has much smaller, 11-13-septate ascospores, 32-56 $\times 3-5 \mu \mathrm{m}$, and $P$. internigrans has smaller, (7-)9-11(-13)-septate ascospores, $51-92 \times 9-17 \mu \mathrm{m} ; P$. internigrans is further distinguished from the new species by a smooth to strongly rugulose-verruculose thallus and convex, hemispherical, well-delimited perithecial verrucae (e.g., see photo at http://www.tropicallichens.net/4028.html). Among the names that are nowadays considered to be synonyms of Porina internigrans (e.g., McCarthy 2001), P. auracariae, described from Australia, differs from the new species by shorter and broader ascospores $(65-78 \times 13-15 \mu \mathrm{m})$ (Müller 1891a); P. brisbanensis, described from Australia, differs by 7-9-septate, shorter and wider ascospores $(\sim 80 \times 16 \mu \mathrm{m})($ Müller 1891a); P. exasperata, described from Australia, differs by 5-9-septate and much smaller ascospores (43-50 × 8-11 $\mu \mathrm{m})$ (Bailey 1886); and P. praestantior, described from Java, differs by slightly shorter and much wider ascospores $(60-100 \times 15-20 \mu \mathrm{m})$ (Müller 1882). Most Porina species have a much thinner perispore, e.g., thin or not apparent in $C$. bellendenica and 2-4 $\mu \mathrm{m}$ in P. internigrans. The North American Porina rhaphidospermum has 14-21-septate ascospores, which are much narrower, 100-140 × 3-5 $\mu \mathrm{m}$.

David \& Hawksworth (1995) reported Porina mastoidea agg. from Plaines Wilhems, Vacoas, Macchabee Forest, on Diospyros tesselaria, 1990, Hawksworth (K-IMI 400613). The detailed description and illustrations given by these authors leave little doubt that they were dealing with the same species as the new one described here. The ascospores they examined were (8-)10-12-septate, 100-120 $\times(15-) 17-20 \mu \mathrm{m}$, similar to those of our specimens. Porina mastoidea differs by smaller, 7(-8)-septate ascospores, 32-66 × 6-13 $\mu \mathrm{m}$ (McCarthy 2001).

Our phylogenetic analyses (Fig. 13) shows that the new species belongs to a clade also containing Porina alba, $P$. imitatrix, $P$. mirabilis, $P$. mastoidea and $P$. radiata, while $P$. internigrans is only distantly related.

Etymology. The new species is dedicated to Vincent Florens, Associate Professor of Ecology and former Head of the Department of Biosciences at the University of Mauritius. $\mathrm{He}$ is mainly interested in the conservation of biodiversity in tropical terrestrial systems, with particular emphasis on the impact of invasive alien species on the biodiversity of tropical forests.

Additional specimens examined. MAURITIUS. Plaines Wilhems: Curepipe, Curepipe Botanical Gardens, on bark, 2019, Diederich 19131; Le Pétrin, between Pétrin Information Centre and first viewpoint along trail to the west, on bark, 2016, Diederich 18348; ibid., 2019, Ertz 23409. Rivière Noire: Same locality as type, 2016, Diederich 18405 , 18426; Brise Fer Forest, on bark, 2019, Diederich 19213, 19220, 19242, 19426. Savanne: Along trail to Mt Cocotte, on bark, 2019, Ertz 23486.

innata (Nyl.) Müll. Arg. McCarthy (2003) erroneously reported this species from Mauritius (confusion with Reunion).

mastoidea (Ach.) Müll. Arg. agg. The report of this species by David \& Hawksworth (1995) almost surely refers to the newly described Porina florensii.

nucula Ach.

Pamplemousses: Jardin Botanique, on bark of Brownea grandiceps, 2016, Ertz 21461.

New for Mauritius.

\section{tetracerae (Ach.) Müll. Arg. var. tetracerae}

Rivière Noire: Chamarel, Ebony Forest, close to park buildings, on bark, 2016, Diederich 18542.

New for Mauritius.

\section{PSEUDEVERNIA Zopf}

mauritiana (Gyelnik) Dodge = Hypotrachyna microblasta

\section{PSEUDOCYPHELLARIA Vain.}

\section{argyracea (Delise) Vain.}

\section{$\equiv$ Cyanisticta argyracea (Delise) Gyeln.}

*= Sticta aspera Laurer, Linnaea 2: 41 (1827); 三 Sticta argyracea var. aspera (Laurer) Kremp., Verh. Zool.-Bot. Ges. Wien 18: 316 (1868); 三 Cyanisticta aspera (Laurer) C. W. Dodge, Beih. Nova Hedwigia 12: 170 (1964). Type: Mauritius, Sieber 40 (L 910,215-1683, lectotype, selected by Galloway \& James 1986) (Galloway 1994: $116,118)$. 

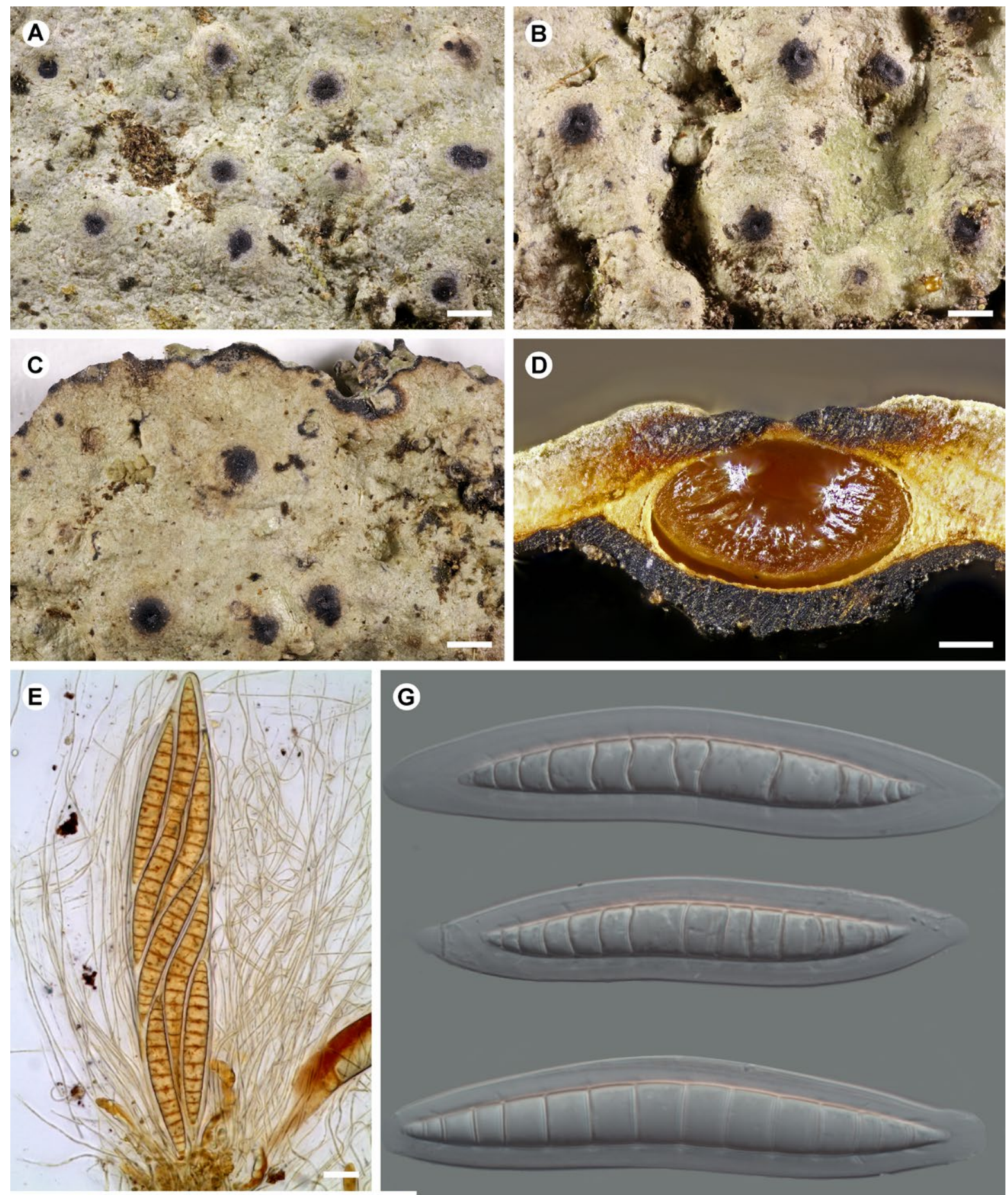

G
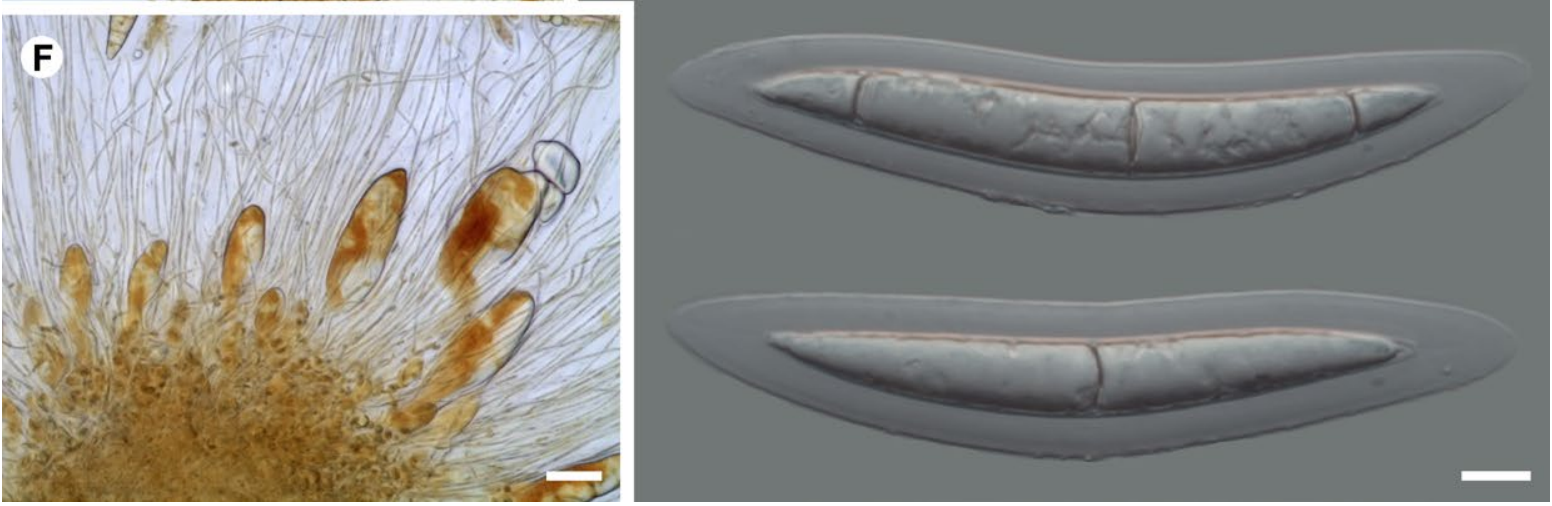

Figure 12. Porina florensii [A: Diederich 18405; B-C: Diederich 18348; D-G: holotype]. A-C - thalli with perithecia immersed in poorly delimited verrucae; black prothallus visible in $\mathrm{C}$; $\mathrm{D}$ - section through wettened perithecium; $\mathrm{E}$ - hymenium with mature 8-spored ascus and paraphyses, in Lugol; $\mathrm{F}$ - lower part of hymenium, with young asci, in Lugol; $\mathrm{G}$ - immature (below) and mature ascospores, showing perispore, in water. Scales: A-C $=1 \mathrm{~mm} ; \mathrm{D}=200 \mu \mathrm{m} ; \mathrm{E}-\mathrm{F}=20 \mu \mathrm{m} ; \mathrm{G}=10 \mu \mathrm{m}$. Photos: P. Diederich. 


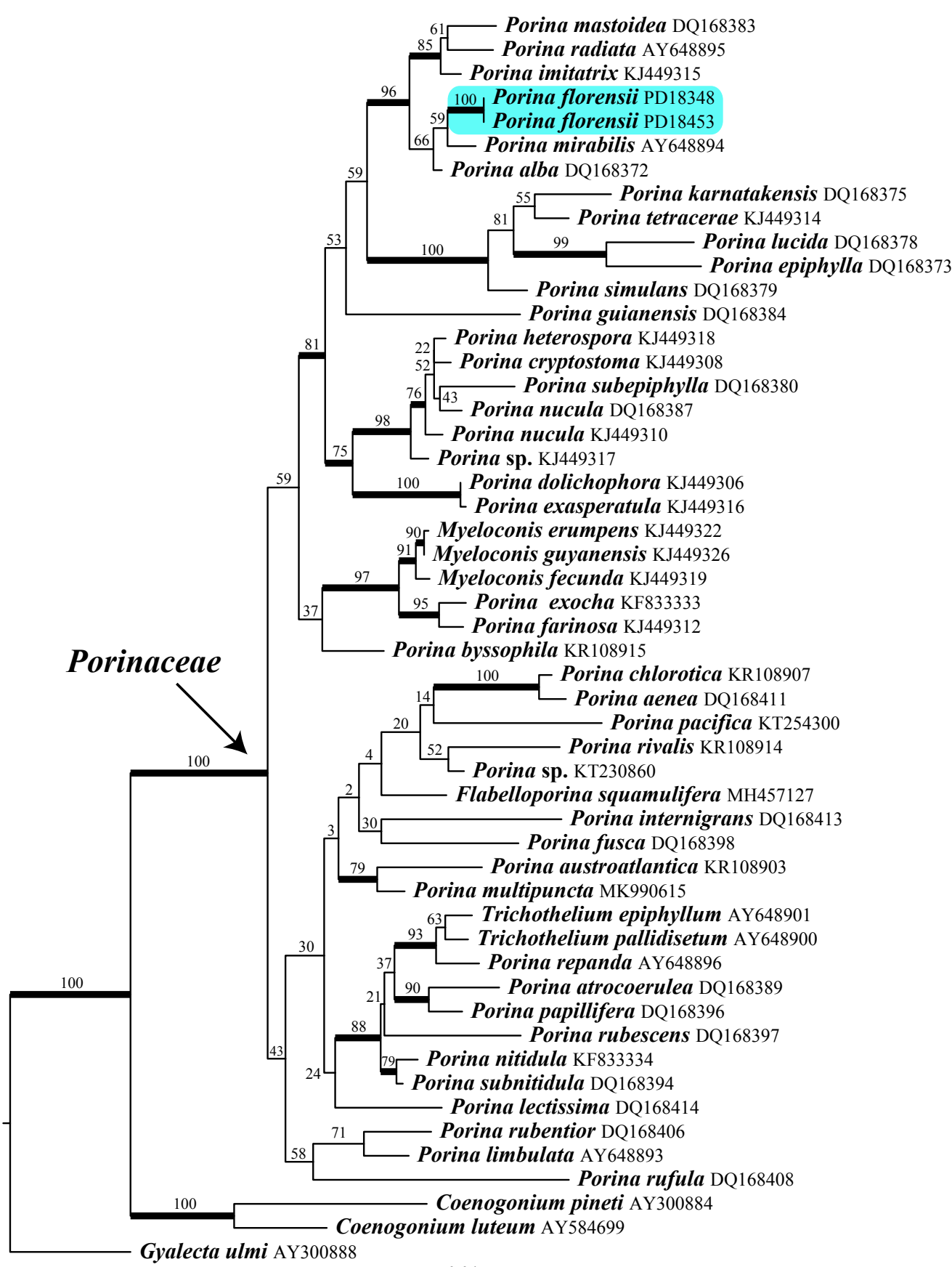

Figure 13. Phylogeny of Porinaceae based on a data set of mtSSU sequences that resulted from a RAxML analysis. Maximum likelihood bootstrap values are shown above or near internal branches. Internal branches considered strongly supported by both the RAxML and Bayesian analyses are represented by thicker lines. The newly sequenced samples of Porina florensii are highlighted.

*= Stictina argyracea $\mathrm{f}$. insidiata Nyl., in Crombie, J. Linn. Soc. (Bot.) 15: 435 (1876); 三 Sticta argyracea f. insidiata (Nyl.) Zahlbr., Cat. Lich. Univ. 3: 371 (1925). Type: Rodrigues, 1874, Balfour 2279 (H-NYL 34058, holotype; BM, isotype). 'The holotype material in Nylander's herbarium is a small scrap taken from a larger collection in Crombie's herbarium (BM) which is preserved as two separate specimens, only one of which is numbered 2279. All three specimens are labelled 'f. isidiata Nyl.' and not insidiata as appears in the protologue' (Galloway 1994: 117).

Rivière Noire: Trail from Plaine Champagne towards Piton de la Petite Rivière Noire, on bark, 2016, Diederich 18428, 18433 (dupl. LG); Chamarel, Ebony Forest, on bark, 2019, Diederich 18942. Savanne: Along trail to Mt Cocotte, on bark, 2019, Diederich 18845, 18871, 18873, 18899, 19377 , 19385 \& Ertz 23465, 23502.

Previously also reported from Mauritius by Lindau (1908), Robillard (W) by Galloway (1994: 118), McGregor 1819 (BM) by Galloway (1994: 118), Vacquois, Ayres (BM) by Galloway (1994: 118), 'in Taylor herb. on sheet 450 at Harvard Univ. com. Müller Argau' by Dodge (1964: 169), Macchabee Forest, 1990, Hawksworth (K-IMI) by David \& Hawksworth (1995) and Crittenden et al. (1995), Bedrock $\left(20^{\circ} 19^{\prime} 02^{\prime \prime} \mathrm{S}, 57^{\circ} 26^{\prime} 78^{\prime \prime} \mathrm{E}\right)$, Pétrin heath, Pétrin rainforest and Le Pouce, 2001, by Holm \& Gregersen (2002), along the road between Mt Cocotte and Bassin Blanc, 1991, Krog \& Timdal (O) by Lücking \& Timdal (2016: 194), and from Rodrigues, 1874, Balfour 2279 (BM) by Galloway (1994: 
118). Further unpublished specimens from Piton de la Petite Rivière Noire, Mt Corps de Garde, Macchabee Forest to Mt Brise Fer, Macchabee Kiosk and Mt Cocotte, collected by Krog \& Timdal in 1991, are kept in O.

aurata (Ach.) Vainio $\equiv$ Crocodia aurata

\section{clathrata (De Not.) Malme}

Galloway \& Arvidsson (1990: 126) reported this species from Mauritius without giving any additional information.

crocata (L.) Vainio

$\equiv$ Sticta crocata $\mathrm{L}$.

$\left(^{*}\right)=$ Pulmonaria aurigera Bory, in Flörke, Mag. Neuesten Entdeck. Gesammten Naturk. Ges. Naturf. Freunde Berlin 2: 126 (1809); ECyanisticta aurigera (Bory) Dodge, Beih. Nova Hedwigia 12: 171 (1964). Type: Les arbres des forêts montagneuses des Iles de France (Mauritius) et de Mascareigne, Bory de Saint-Vincent (PC-Thuret, lectotype, fide Galloway 1988: 113) (Galloway et al. 2001: 56; Dodge 1964: 171-172).

$\left(^{*}\right)=$ Sticta aurigera var. nuda Delise, Hist. Lich. Sticta: 55 (1825). Type: Iles de France (Mauritius) et Mascareigne, ?Bory de Saint-Vincent (PC-Thuret, lectotype, selected by Galloway \& James 1986).

*=Sticta mougeotiana Delise, Hist. Lich. Sticta: 6213 (1825); E Cyanisticta mougeotiana (Delise) Dodge, Beih. Nova Hedwigia 12: 177 (1964). Type: Ile de France, Bory de Saint-Vincent (PC-Thuret, lectotype, selected by Galloway \& James 1986) (Galloway et al. 2001: 56).

$\left(^{*}\right)=$ Sticta mougeotiana var. xantholoma Delise, Hist. Lich. Sticta: 63 (1825). Type: 'Insulae Borboniae ou Franciae' [i.e., Reunion or Mauritius] (PC-Lenormand, lectotype, selected by Galloway \& James 1986).

Also reported from Mauritius, 'auf Rinde' by Lindau (1908) and Moncada et al. (2014: 122), Wight, by Dodge (1964: 178), 'Sur les arbres, dans le quartier de Pampelmousses, à l'île Maurice' by Bélanger (1834), Pouce Mt, Ayres (BM) by Galloway (1994: 125) and Curepipe (BM) by Galloway (1994: 125). Further unpublished specimens from Mt Corps de Garde, Mt Cocotte and Curepipe Botanical Garden, collected by Krog \& Timdal in 1991, are kept in O.

The species was also reported from Mauritius, Søchting 30A13a (TUR) by Stenroos et al. (2006) [almost surely the same collection as the one reported by Holm \& Gregersen (2002) from Pétrin heath, 2001 (C)], but Lücking et al. (2017a: 451) concluded that this specimen is best included in $P$. desfontainii because of the presence of laminal isidia. This specimen was sequenced and included in a phylogenetic study by Lücking et al. (2017a).

\section{desfontainii (Delise) D. J. Galloway}

Savanne: Along trail to Mt Cocotte, on bark, 2019, Diederich 18878 \& Ertz 23463.

Also reported from Mauritius, McGregor (BM), Les Mares, Ouhamed 8 (BM) by Galloway (1994: 128), Le Pouce, 2001, Søchting 30A13a p. p. (C) by Lücking et al. (2017a), Bedrock $\left(20^{\circ} 19^{\prime} 02^{\prime \prime} \mathrm{S}, 57^{\circ} 26^{\prime} 78^{\prime \prime} \mathrm{E}\right)$ and Le Pouce, 2001 , by Holm \& Gregersen (2002). Further unpublished specimens from Piton de la Petite Rivière Noire, Le Pouce and Mt Cocotte, collected by Krog \& Timdal in 1991, are kept in O.

dissimilis (Nyl.) D. J. Galloway \& P. James [三Stictina dissimilis Nyl.]. Reported from Rodrigues, on trees, 1874, Balfour 2277, by Crombie (1876b)

\section{dozyana (Mont. \& Bosch) D. J. Galloway}

Savanne: Along trail to Mt Cocotte, on bark, 2019, Diederich 19378.

Our specimen is rather typical, with a cyanobacterial photobiont, a white medulla, an upper uneven surface devoid of pseudocyphellae, a lower surface with white protruding pseudocyphellae, and marginal, greyish soralia distinctly eroding yellow below, and it agrees with descriptions in Galloway (1994) and Lücking et al. (2017). Additional unpublished specimens from Mt Cocotte, collected by Krog \& Timdal in 1991, are kept in O.

New for Mauritius.

\section{gilva (Ach.) Malme}

Reported from Mauritius, Blackburn (BM) by Galloway (1994: 133).

intricata (Delise) Vain. Galloway (1994) indicated the presence of this species in Mauritius on a distribution map (fig. 19), but no corresponding specimen is listed under 'Specimens examined': possibly a lapsus for Reunion, from where the species has been described. Holm \& Gregersen (2002) reported this species as 'Uncommon on Mauritius and $\mathrm{La}$ Réunion', also probably a lapsus, as their only specimen examined is from Reunion.

\section{neglecta (Müll. Arg.) H. Magn.}

Savanne: Along trail to Mt Cocotte, on bark, 2019, Diederich 18881, 18883 \& Ertz 23513.

Also reported from Le Pouce, 2001, Søchting 30A13a p. p. (C, TUR) by Lücking et al. (2017a). Our specimens perfectly agree with the description given by Lücking et al. (2017).

orygmaea (Ach.) Malme [三 Sticta orygmaea Ach.]. Reported from Mauritius by Laurer (1827).

PSOROMA Ach. ex Michx.

sphinctrinum (Mont.) Nyl. $\equiv$ Pannaria sphinctrina

\section{PULMONARIA Hoffm.}

aurigera Bory $=$ Pseudocyphellaria crocata

dichotoma Bory $\equiv$ Sticta dichotoma

$\left.{ }^{*}\right)$ gigantea Bory in Flörke, Magazin Ges. naturf. Fr. Berlin 2: 127 (1809). Type: 'An den Bäumen der Inseln Frankreich [Mauritius] und Bourbon [Reunion]', Bory de Saint-Vincent (PC-Thuret, holotype). Following Galloway (1995), this is an earlier name for Sticta plumbea Delise. Galloway (1995) lectotypified the latter name on a specimen from Reunion. Following Simon et al. (2018), the species exists only in Reunion.

\section{PYRENASTRUM Eschw.}

americanum Spreng. = Pyrenula astroidea

\section{PYRENULA Ach.}

astroidea (Fée) R. C. Harris [= Pyrenastrum americanum Spreng.]. Reported from Rodrigues, on thin bark of trees, 1874, Balfour 2274 (Crombie 1876b).

\section{complanata (Mont.) Trevis.}

Plaines Wilhems: Le Pétrin, between Pétrin Information Centre and first viewpoint along trail to the west, on bark, 2016, Diederich 18350.

New for Mauritius. 
confinis (Nyl.) R. C. Harris [= P. corticata (Müll. Arg.) R. C. Harris, fide Aptroot 2012]. Reported from Mauritius by Crittenden et al. (1995, as $P$. cf. corticata).

cruenta (Mont.) Vain.

$\equiv$ Trypethelium cruentum Mont.

*= Trypethelium cruentulum Nyl., in Crombie, Journ. Linn. Soc., Bot. 15: 445 (1876). Type: Rodrigues, on branches of trees, 1874, Balfour 2240 (Crombie 1876b).

Also reported from Rodrigues, on bark of trees, 1874, Balfour 2275 (Crombie 1876b, sub T. cruentum).

\section{fetivica (Krempelh.) Müll. Arg.}

*=? Pyrenula truncata Müll. Arg., nom. nud.? Original material: Mt Pouce, P. B. Ayres (G 00293752).

Plaines Wilhems: Le Pétrin, between Pétrin Information Centre and first viewpoint along trail to the west, on bark, 2016, Diederich 18345, 18349; Le Pétrin, heathland NW of Pétrin Information Centre, on bark, 2019, Ertz 23331.

Pyrenula truncata probably is a synonym of $P$. fetivica, fide Aptroot (2012). We were not able to find any paper describing $P$. truncata. An annotation on the specimen conserved in G says 'Pyrenula truncata Müll. Arg. ined.', suggesting that the name has never been published. The name is also missing in the online databases Index Fungorum and MycoBank.

\section{mamillana (Ach.) Trevis.}

三Verrucaria mamillana Ach.; = Pyrenula marginata Hook. (fide Aptroot 2012); 三Verrucaria marginata (Hook.) Hepp

Plaines Wilhems: Le Pétrin, along trail W of Pétrin Information Centre, up to $600 \mathrm{~m} \mathrm{~W}$ of first viewpoint, on bark, 2019, Diederich 18776. Rivière Noire: Trail from Plaine Champagne towards Piton de la Petite Rivière Noire, on bark, 2016, Diederich 18431; Brise Fer Forest, on bark, 2019, Diederich 19210, 19223, 19437, 19427, 19435 \& Ertz 24293.

Previously reported 'Sur l'écorce des arbres, à l'île Maurice' by Bélanger (1834) (PC0018922) and from Mauritius by Daruty (1873).

Pyrenula muriciliata Diederich \& Ertz, sp. nov. (Fig. 14)

\section{MycoBank MB 834929}

Diagnosis: Characterized by a thin, brownish to greyish brown, ecorticate thallus, $0.5-0.7 \mathrm{~mm}$ wide perithecia with an apical ostiole, and dark brown, muriform ascospores, each with a basal cilium.

Type: Mauritius, Rivière Noire, Black River Gorges National Park, $5 \mathrm{~km} \mathrm{NW}$ of Pétrin, Brise Fer Forest, $20.3779^{\circ} \mathrm{S}$, $57.4404^{\circ} \mathrm{E}( \pm 200 \mathrm{~m})$, alt. $585 \mathrm{~m}$, on the bark of a tree, 10 Sept. 2019, Diederich 19226 (MAU, holotype; BR, herb. Diederich, isotypes).

Description. Thallus ecorticate, brownish to greyish brown, continuous, very thin $(20-70 \mu \mathrm{m})$; prothallus medium to dark brown; photobiont Trentepohlia. Ascomata perithecioid, simple, dispersed to aggregated, sometimes confluent, subspherical to conical, emergent, $0.5-0.7 \mathrm{~mm}$ diam., black, not covered by the thallus. Wall laterally and apically more or less equally carbonized, $\mathrm{K}-, 100-150 \mu \mathrm{m}$ thick, basally reduced or missing. Ostiole more or less apical. Hamathecium hyaline, densely inspersed with oil droplets; paraphyses unbranched, 1-1.5 $\mu \mathrm{m}$ thick. Asci cylindrical, I-, 8-spored, 90-120 × 10-12.5 $\mu \mathrm{m}$. Ascospores when young hyaline, soon dark brown, I-, muriform with 3 transverse eusepta and each row with (0-)1 longitudinal septum, ellipsoid, not or slightly constricted near septa, (13-)14.3-16.7(-18) × (8-)8.5-10.1(-11.5) $\mu \mathrm{m}$, ratio $\mathrm{L} / \mathrm{B}(1.4-) 1.6-1.8(-1.9)(\mathrm{n}=53$, from holotype $)$, ends rounded, lumina rounded (best visible in hyaline young ascospores), basally with a $2-10 \mu \mathrm{m}$ long and $0.5-0.7 \mu \mathrm{m}$ thick, straight or sometimes curved cilium. Pycnidia not observed. Chemistry: thallus $\mathrm{K}-, \mathrm{C}-, \mathrm{KC}-, \mathrm{P}-$, $\mathrm{UV}-$; no substance detected by TLC (solvent A).

Ecology and distribution. The new species is corticolous on the bark of trees in forests and parklands. It is known from three Mauritian localities (Brise Fer Forest, Pétrin, Curepipe) at 565-680 m elevation.

Notes. The new species differs from all known Pyrenula species by ascospores presenting a basal cilium. Aptroot (2012) reported two species with ciliate ascospores: $P$. ciliata Aptroot and P. hirsuta Etayo. They both differ from the new species by the presence of many hyaline cilia at both ends (vs one basal cilium) and by transseptate (vs muriform) ascospores. As the cilium may have been overlooked in other species, especially when using a microscope without DIC optics, the new species needs to be compared with similar species with muriform ascospores. Using Aptroot (2012), it keys out at Pyrenula borneensis Aptroot ined., formally described by Aptroot et al. (2012), a species readily distinguished by much larger ascospores, 20-26 × 10-12 $\mu \mathrm{m}$, lacking a basal cilium, and larger ascomata, $0.5-1.3 \mathrm{~mm}$ diam.

Etymology. The epithet refers to the muriform ascospores, each with a basal cilium.

Additional specimens examined. MAURITIUS. Plaines Wilhems: Curepipe, Curepipe Botanic Gardens, on bark, 2016, Diederich 18296; Le Pétrin, between Pétrin Information Centre and first viewpoint along trail to the west, on bark, 2016, Diederich 18347.

nitida (Weigel.) Ach. [三Verrucaria nitida (Weigel.) Schrad.]. The report from Mauritius by Daruty (1873) is erroneous, as the corresponding specimen (Daruty 63, MAU) belongs to Glyphis cicatricosa.

ochraceoflava (Nyl.) R. C. Harris

Moka: Réduit, State House Park, on bark, 2019, Ertz 23300. Pamplemousses: Jardin Botanique, on bark of palm tree, 2016, Diederich 18244.

New for Mauritius.

parvinuclea (Meyen \& Flot.) Aptroot

Rivière Noire: East of Black River, from Visitor's Centre to Pilgrims Trail, on bark, 2016, Diederich 18490.

New for Mauritius.

quassiicola (Fée) Fée

$=P$. pinguis Fée, fide Aptroot 2012

Pamplemousses: Jardin Botanique, on bark of Brownea grandiceps, 2016, Ertz 21460.

Already known from Mauritius 'Sur l'écorce des arbres, dans la péninsule indienne et à l'île Maurice' (Bélanger 1834, sub P. pinguis). In the phylogenetic tree of the Pyrenulaceae (Fig. 16) our specimen is nested in a poorly resolved clade including specimens of Pyrenula 

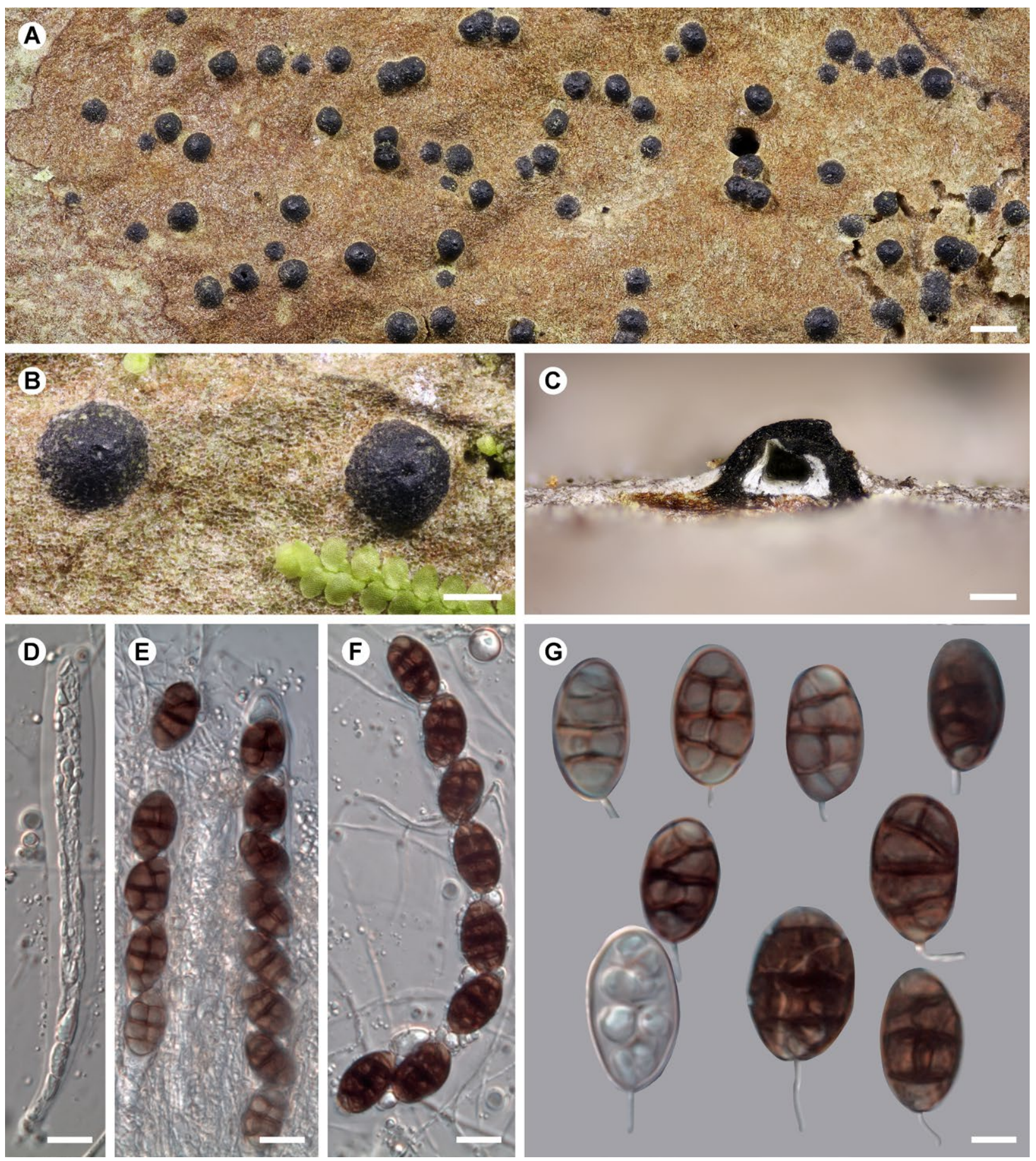

Figure 14. Pyrenula muriciliata [A-B: holotype; C-G: Diederich 18347]. A-B - thallus with perithecia; dark prothallus visible in A; C - section through dry perithecium; D - young ascus, in water; $\mathrm{E}$ - inspersed hymenium with two asci and ascospores, in water; $\mathrm{F}-8$-spored ascus and paraphyses, in water; $\mathrm{G}$ - muriform ascospores with basal cilium, in water; young immature ascospore on bottom left. Scales: $\mathrm{A}=1 \mathrm{~mm}$; $\mathrm{B}=500 \mu \mathrm{m} ; \mathrm{C}=200 \mu \mathrm{m} ; \mathrm{D}-\mathrm{F}=10 \mu \mathrm{m} ; \mathrm{G}=5 \mu \mathrm{m}$. Photos: P. Diederich.

quassiicola, P. bahiana, P. sexlocularis and P. thelomorpha, while other specimens of $P$. quassiicola are more distantly related. As already shown by Gueidan et al. (2016), species delimitation of the widespread pantropical P. quassiicola is problematic, because the species is polyphyletic, with at least four distinct lineages highlighted in their threegene dataset.

sexlocularis (Nyl.) Müll. Arg.

Rivière Noire: East of Black River, from Visitor's Centre to Pilgrims Trail, on bark, 2016, Diederich 18488.

New for Mauritius.

\section{PYXINE Fr.}

cocoes (Sw.) Nyl.

Moka: Réduit, State House Park, on bark, 2019, Diederich 19288; ibid., on bark of Cinnamomum, Diederich 19316. Rivière Noire: Le Morne Peninsula, S coast, on bark, 2019, Diederich 19251.

Also reported from Mauritius by Daruty (1873) and from Ile aux Aigrettes by Parnell et al. (1989) (BM, det. James). Further unpublished specimens from Yemen, Flic-en-Flac, Tamarin, Morne Brabant, Flacq and Ile aux Aigrettes, collected by Krog \& Timdal in 1991, are kept in O. 
palmicola. A lapsus for Coccocarpia palmicola in Parnell et al. (1989: 374).

*petricola Nyl. ex Cromb.

J. Bot. 14: 263 (1876). Type: Rodrigues, on rocks, 1874, Balfour 2391 (E, H) (Crombie 1876a, b).

Reported from Ile aux Aigrettes (BM, det. James) by Parnell et al. (1989).

\section{petricola var. pallida Swinscow \& Krog}

Rivière Noire: Le Morne Peninsula, S coast, on bark, 2019, Diederich 19550 \& Ertz 24272.

Our specimens have apothecia with a brownish white and $\mathrm{K}$ - internal stipe characteristic of var. pallida (Swinscow $\&$ Krog 1975). New for Mauritius.

\section{retirugella Nyl.}

Rivière Noire: Chamarel, Ebony Forest, around viewpoint, on bark, 2016, Diederich 18531.

Further unpublished specimens from Mt des Créoles and Ile aux Aigrettes, collected by Krog \& Timdal in 1991, are kept in O. New for Mauritius.

retirugella f. sorediigera Müll. Arg. Reported from Mauritius by Dodge (1971: 171).

\section{subcinerea Stirton}

Moka: Réduit, State House Park, on bark, 2019, Diederich 19289; ibid., on bark of Ficus microcarpa, Diederich 19280.

Rivière Noire: Le Morne Peninsula, S coast, on bark, 2019, Diederich 19252.

Also reported from Mt des Créoles, 1991, Krog \& Timdal (O) by Lücking \& Timdal (2016: 198). Further unpublished specimens from Yemen, Tamarin and Flacq, collected by Krog \& Timdal in 1991, are kept in O.

\section{RAMALINA Ach}

arabum (Dill. ex Ach.) Meyen \& Flot.

Reported from Mauritius by Daruty (1873). The corresponding specimen (Mauritius, Iles aux Aigrettes, 1873, Daruty 143, MAU L1964) was studied by Krog (1994), who confirmed its identity.

calicaris (L.) Röhl.

Reported from W side of Round Island, on Fernelia buxifolia (Johnston 1894: 263). As the species is unknown from Africa and Australia, this possibly refers to $R$. subfraxinea var. leiodea.

canaliculata Taylor. Reported from Mauritius by Nylander (1870), and from Rodrigues, on branches of trees, 1874, Balfour 2210, by Crombie (1876b). A poorly known species.

*canaliculata f. brevior Cromb., J. Linn. Soc., Bot. 15: 434 (1876). Type: Rodrigues, on branches of trees, 1874, Balfour 2386 (Crombie 1876b). A poorly known taxon.

farinacea (L.) Ach. Reported from Mauritius by Daruty (1873) and from Rodrigues, on branches of trees, 1874, Balfour 2324, by Crombie (1876b).

farinacea f. pendula (Schrad.) Cromb. Reported from Rodrigues, on branches of trees, 1874, Balfour 2324b (Crombie 1876b).

gracilenta (Ach.) Röhl. Reported from Rodrigues, on rocks and trees, 1874, Balfour 2283, 2297, by Crombie (1876b). "gracilenta f. nodulosa Cromb., J. Linn. Soc., Bot. 15: 434 (1876). Type: Rodrigues, on rocks, 1874, Balfour 2297b (BM). A poorly known taxon.

intermedia Delise ex. Nyl. Reported from Rodrigues, on rocks, 1874, Balfour 2284, by Crombie (1876b).

linearis var. pumela Mont. Reported from Mauritius by Daruty (1873). A poorly known taxon.

\section{litorea $\mathrm{N}$. Stevens}

Reported from Mauritius (saxicolous) and Rodrigues (saxicolous) (M, as $R$. microspora, with evernic acid) (Stevens 1986: 187; 1987: 169).

maritima Krog \& Swinscow. Reported from Ile aux Aigrettes, on Maytenus pyria, by Parnell et al. (1989) (BM, det. James). This species strongly resembles Ramalina subfraxinea var. leiodea (Stevens 1987: 207), and therefore the specimen might belong to that species.

nervulosa (Müll. Arg.) des Abb.

Moka: Réduit, State House Park, on bark, 2019, Diederich 18700 [medulla K-]; ibid., on bark of Latania lodigesii, Diederich 18705 [medulla K-]; Réduit, close to Mauritius Herbarium building, on bark, 2019, Ertz 23249 [medulla K+ pink]. Pamplemousses: Jardin Botanique, on bark, 2016, Diederich 18263 (dupl. LG) [medulla K+ pink]; ibid., on bark of Dypsis lutescens, Ertz 21470 [medulla $\mathrm{K}+$ pink]; $1 \mathrm{~km}$ NNW of Botanical Garden, S of Museum 'Aventure du sucre', on bark, 2016, Diederich 18509 (dupl. LG) [medulla $\mathrm{K}-$ ].

Previously reported from Pamplemousses Botanical Garden, 1990, Hawksworth (K-IMI) by Crittenden et al. (1995) and from the same locality, 1987, Kubodera (TNS) by Kashiwadani \& Moon (2007).

\section{sprengelii Krog \& Swinscow}

Rivière Noire: Trail from Plaine Champagne towards Piton de la Petite Rivière Noire, on bark, 2016, Diederich 18458 (dupl. LG) (specimen kept under Lichenopeltella ramalinae); ibid., 2019, Ertz 23973, 24037; Chamarel, Ebony Forest, around viewpoint, on bark, 2016, Diederich 18538 (dupl. LG); ibid., along trail W of viewpoint, on bark, 2019, Diederich 18943.

New for Mauritius.

subcalicaris Nyl. Reported from Mauritius (herb. Lenorm.) by Nylander (1870: 139).

subfraxinea Nyl. Reported from Mauritius by Daruty (1873), Gretan (ex herb. Lenorm.) by Nylander (1870: 139), and from Rodrigues, on branches of trees, 1874, Balfour 2340, by Crombie (1876b). Probably refers to $R$. subfraxinea var. leiodea (Stevens 1987).

\section{subfraxinea var. leiodea (Nyl.) N. Stevens}

Reported from Mauritius, corticolous, Gretan (herb. Lenorm.: H-NYL or PC?) (with boninic ac.) by Nylander (1870: 139, sub $R$. subfraxinea) and Stevens (1987: 203, 207-208), and from Mauritius (H-NYL 37185) (with bononic ac.) by Krog \& Swinscow (1976: 167, sub R. subfraxinea; belongs to var. leiodea, fide Stevens 1987: 207).

\section{RELICINA (Hale \& Kurok.) Hale}

limbata (Laurer) Hale [三 Parmelia limbata Laurer]. Reported from Mauritius by Lindau (1908). 


\section{RHABDODISCUS Vain.}

fissus (Nyl.) Vain.

三Stegobolus fissus (Nyl.) A. Frisch

Reported from Mauritius, 1876, Robillard (G), on the shoulder of the Pouce (BM), and Pouce, Ayres (BM) by Frisch \& Kalb (2006: 460).

\section{RICASOLIA De Not.}

amplissima (Scop.) De Not. [= Parmelia glomulifera (Lightf.) Ach.]. 'Sur les rochers et sur les arbres, aux îles Maurice et de Bourbon' (Bélanger 1834).

crenulata var. stenospora Nyl. = Ricasolia sublaevis

\section{sublaevis Nyl.}

$\left(^{*}\right)=$ Ricasolia crenulata var. stenospora Nyl., Ann. Sci. Nat., Bot., sér. 4, 11: 254 (1859). Type: Mauritius (H-Nyl 33387, syntype, identified by I. Yoshimura as $R$. sublaevis. N.B.: syntype H-Nyl 33382 'is not $R$. sublaevis and not belong to $R$. crenulata', fide Yoshimura, herbarium annotation) and Reunion (H-Nyl. 33380, syntype, identified by Y. Yoshimura as $R$. sublaevis).

*= Parmelia quercizans var. denudata Laurer, Linnaea 2: 40 (1827). Type: ‘Ad arbores Insulae St. Mauritii', Sieber. This name was considered a synonym of $R$. crenulata var. stenospora by Dodge (1964: 158).

${ }^{*}=$ Lobaria wightii C. W. Dodge, Beih. Nova Hedwigia 12: 158 (1964). Type: Mauritius, Wight (FH 00302075). Published as nom. nov. for var. denudata and var. stenospora.

Also reported from Mauritius by Daruty (1873) and Hue (1892: 101).

\section{RIMELIA Hale \& A. Fletcher}

reticulata (Taylor) Hale \& Fletcher $\equiv$ Parmotrema reticulatum

subisidiosa (Müll. Arg.) Hale \& Fletcher $\equiv$ Parmotrema subisidiosum

\section{RINODINA (Ach.) Gray}

luridescens (Anzi) Arnold [= Lecanora coniopta Nyl.]. Reported from Rodrigues by Dodge (1971: 10).

oxydata (A. Massal.) A. Massal. Reported from Moka, below Mt Ory, on shaded volcanic rocks by a track, 1990, Hawksworth (K-IMI) by David \& Hawksworth (1995; 'agrees in all characters ... except that the thallus does not react with K') and Crittenden et al. (1995, as Rinodina cf. oxydata).

\section{ROCCELLA DC.}

\section{boryi Delise ex Fée}

*= Roccella montagnei f. teretior Cromb., J. Linn. Soc., Bot. 15: 433 (1876). Type: Rodrigues, on rocks, 1874, Balfour 2206, 2288 (BM 674747, lectotype selected by Tehler \& Irestedt 2007; BM 674746, H-NYL 36728, H-NYL 36735 , isolectotypes) (Tehler et al. 2010).

${ }^{*}=$ Roccella flaccida Bory, Dict. Class. Hist. Nat. 14: 631 (1828); 三 Roccella flaccida Delise ex Darb., Biblioth. Bot. 9: 44 (1898) nom. hom. Type: Ile de France [Mauritius], 1826, Jussieu 2444 (PC, lectotype selected By Tehler \& Irestedt 2007; PC, isolectotype) (Tehler et al. 2010).

Also reported from Mauritius by Fée (1824: CI), from Port Louis, Mt Signal, 2003, Tehler (S, UPS), Black River, Pointe Corail de la Prairie, 2003, Tehler (S, UPS), Black River, Mt
St. Pierre, the eastern peak near Bambous, $\sim 7 \mathrm{~km}$ E Quatre Bornes, 2003, Tehler (S, UPS), Black River, in gorge just E of Cascavelle, $\sim 7 \mathrm{~km} \mathrm{~W}$ of Quatre Bornes, on vertical cliffs, 2003, Tehler 8521 (UPS), Plaine Wilhems, Corps de Garde, 2003, Tehler (S, UPS), and Savanne, Maconde, 2003, Tehler (S), by Tehler et al. (2010).

flaccida Delise $=$ Roccella boryi

fuciformis (L.) DC. Reported from Mauritius by Daruty (1873) and 'Sur les rochers du grand port, à l'île Maurice' by Bélanger (1834).

fuciformis var. gracilenta Vain. ex Darb. Reported from Mauritius by Daruty (1873).

mauritiana Darb. Although the epithet refers to Mauritius and a Mauritian specimen (NMW 0000953) is annotated as 'isotype' of $R$. mauritiana, this name is a nomenclatural synonym of Roccella fuciformis $\mathrm{f}$. linearis and thus based on the type of the latter name from Sumatra.

montagnei f. teretior Cromb. $=$ Roccella boryi

phycopsis Ach. Reported from Mauritius by Daruty (1873).

tinctoria DC. Reported from Mauritius by Nylander (1859: 252). See notes under Roccellina hypomecha.

tinctoria var. hypomecha Ach. $\equiv$ Roccellina hypomecha

\section{ROCCELLINA Darb.}

hypomecha (Ach.) Tehler [三 Roccella tinctoria var. hypomecha Ach.)]. Reported from Mauritius by Nylander (1859). Following Tehler (pers. comm.), several Mauritius specimens in PC-Delise, incorrectly identified as $R$. hypomecha, belong to Roccella boryi. One specimen labelled 'Roccella tinctoria - Ile de France' (S-L21425), with a handwriting resembling that of Nylander, belongs to R. hypomecha; it might have been taken by Nylander from Commerson's herbarium in Paris, where other collections state both 'Cap Bon de S.' and 'Ile de France' on the same label; consequently, it must be considered likely that this specimen is mislabelled and does not originate from Mauritius.

\section{ROLFIDIUM Moberg}

*coccocarpioides (Nyl. ex Cromb.) Timdal

Opera Bot. 110: 121 (1991); 三Lecidea coccocarpioides Nyl. ex Cromb., J. Bot., Lond. 14: 264 (1876). Type: Rodrigues, on rocks, 1874, Balfour 2219 (BM, H-NYL 13025, syntypes) (Crombie 1876a, b; Timdal 1991: 121).

Rivière Noire: East of Black River, from Visitor's Centre to Pilgrims Trail, on rocks along trail, 2016, Diederich 18474; Chamarel, Ebony Forest, around viewpoint, saxicolous, on exposed rocks, 2016, Diederich 18519 (MAU); ibid., 2019, Diederich 18919.

Also reported from Mt Corps de Garde, 430 m, 1991, Krog \& Timdal (OMAU, O) by Kistenich et al. (2018: 904), and from continental Africa by Swinscow \& Krog (1988).

\section{SAGEDIOPSIS Vain.}

\section{+pertusariicola Zhurb.}

Rivière Noire: Trail from Plaine Champagne towards Piton de la Petite Rivière Noire, on bark, on Pertusaria sp., 2016, Diederich 18434.

Zhurbenko (2009) showed that the material of Sagediopsis growing on Pertusaria slightly differs by several 
morphological characters from S. campsteriana (Linds.) D. Hawksw. \& R. Sant., a species possibly confined to Ochrolechia, and he consequently described the new $S$. pertusariicola. The Mauritius specimen is in a very poor condition, with most perithecia either immature or overmature. We observed mainly immature, 1-septate ascospores, 11.5-14 $\times 3-4 \mu \mathrm{m}$, and a single 2 - or 3-septate ascospore, $13.2 \times$ $3.2 \mu \mathrm{m}$. These fall in the lower range of 3-septate ascospores of $S$. pertusariicola, given as (11-)17.5-24(-31) $\times$ (3-)4-5(-6) $\mu \mathrm{m}$ by Zhurbenko (2009). Although our specimen cannot be distinguished on a morphological basis from $S$. campsteriana, we include it in $S$. pertusariicola because of the host selection. The host is a fertile Pertusaria with apothecia immersed in convex warts, with punctiform hymenia. New for Mauritius.

\section{SARCOGRAPHA Fée}

tricosa (Ach.) Müll. Arg.

$\equiv$ Medusula tricosa (Ach.) Mont.

Pamplemousses: Jardin Botanique, on bark of Ptychosperma macarthurii, 2016, Ertz 21453.

Previously reported from Mauritius by Daruty (1873).

*tricosula (Nyl. ex. Cromb.) Zahlbr., Cat. Lich. Univ. 2: 467 (1923 ['1924']); 三 Glyphis tricosula Nyl. ex Cromb., J. Bot. 14: 264 (1876). Type: Rodrigues, on the thin epidermis of bark, 1874, Balfour 2363 (BM, H) (Crombie 1876a, b).

\section{SARCOGRAPHINA Müll. Arg.}

heterospora (Nyl.) Z. F. Jia \& Lücking [三 Phaeographina heterospora (Nyl.) Zahlbr.]. This species was described from Reunion but later reported by Dodge (1964: 76) as known only from Mauritius, which is most likely a lapsus.

\section{SERUSIAUXIA Ertz \& Diederich, gen. nov.}

MycoBank MB 834931

Diagnosis: Distinguished from all known Pyrenulaceae genera by a sorediate thallus and chemistry with gyrophoric acid (C+ red soralia).

Type: Serusiauxia inexpectata Ertz \& Diederich.

Description. See specific description below.

Notes. In our phylogenetic tree (Fig. 16), this lichen is sister taxon to Lithothelium septemseptatum in a basal position within a main clade including also the genus Anthracothecium and several species of Pyrenula (including the generic type, $P$. nitida). This clade was defined as 'Pyrenulaceae, Group 1' in the phylogeny of the Pyrenulaceae by Gueidan et al. (2016). We wondered if we should include our new species within an enlarged concept of Pyrenula, which would then include the two Pyrenula clades recognized by Gueidan et al. (2016), the genus Anthracothecium and Lithothelium septemseptatum. However, the phylogenetic results strongly suggest that Pyrenula needs to be split into several genera. 'Pyrenulaceae, Group 1' is divided, with high support, in a clade comprising Pyrenula s.str. and Anthracothecium, and a second clade comprising our new species and Lithothelium septemseptatum. Following our tree, the two taxa are genetically rather distinct. Further, as long as the type of Lithothelium has not been sequenced, we cannot affirm that this clade refers to Lithothelium s.str. Finally, to our knowledge the new species is unique within the Pyrenulaceae by having a sorediate thallus and chemistry with lecanoric/gyrophoric acid, strongly resembling Dendrographa decolorans. We conclude that the description of a new genus Serusiauxia is the best option, supported by both molecular results and morphological characters.

Etymology. Named after Emmanuël Sérusiaux (Liège, Belgium) to honour his outstanding contribution to the lichenology of tropical regions.

\section{Serusiauxia inexpectata Ertz \& Diederich, sp. nov.}

(Figs 15-16)

\section{MycoBank MB 834932}

Diagnosis: Distinguished from all known Pyrenulaceae species by a sorediate thallus and chemistry with gyrophoric acid $(\mathrm{C}+$ red soralia).

Type: Mauritius, Pamplemousses district, Pamplemousses, Sir Seewoosagur Ramgoolam Botanical Garden, 20 06' $21^{\prime \prime} \mathrm{S}$, $57^{\circ} 34^{\prime} 49^{\prime \prime}$ E, elev. $80 \mathrm{~m}$, on bark of a \pm vertical trunk of Terminalia, 29 Dec. 2016, Ertz 21490 (MAU - holotype, BR, herb. Diederich - isotypes).

Description. Thallus crustose, thin, rather inconspicuous, mostly endophloeodal, whitish to pale cream; prothallus brownish. Photobiont trentepohlioid, with cells $6-11 \times$ 4-8 $\mu \mathrm{m}$. Soralia numerous, dense, punctiform when young, erumpent, flat to slightly convex with loosely heaped soredia, mostly rounded, up to $0.6 \mathrm{~mm}$ diam, spreading and becoming confluent, sometimes almost forming a continuous leprose crust covering large areas of the thallus, pale creamish brown, rarely pale greyish-almost white. Soredia without projecting hyphae, $25-60 \mu \mathrm{m}$ diam; hyphae $2-2.5 \mu \mathrm{m}$ diam covered by tiny hyaline crystals dissolving in $\mathrm{K}$ (polarized light!); presence of calcium oxalate crystals mostly $0.5-4 \mu \mathrm{m}$ diam, a few larger up to $12 \mu \mathrm{m}$ diam $\left(\mathrm{H}_{2} \mathrm{SO}_{4} 25 \%\right.$ !). Ascomata and conidiomata unknown. Chemistry: thallus and soralia $\mathrm{C}+$ red fleeting, $\mathrm{K} \pm$ pale yellowish (weak), $\mathrm{P}-, \mathrm{UV}-$, I-, KI-. TLC revealed gyrophoric acid in solvents B' and EA (specimens Ertz 21490, 21496, Diederich 17815 and 18239 tested).

Ecology and distribution. The species is known from the Sir Seewoosagur Ramgoolam Botanical Garden and the Curepipe Botanic Gardens in Mauritius, where it grows on the bark of big trees, including Mangifera and Terminalia, and from the isle of Mahé in the Seychelles, where it has been collected in the 'Jardin du Roi' parkland.

Notes. The new species is most similar to Dendrographa decolorans (Arthoniomycetes), which differs by soralia with a mauve-grey to pale lilac-grey colour, different chemistry (unidentified fatty acids; thallus $\mathrm{C}-$ ) (Wolseley \& Hawksworth 2009), a non-tropical distribution (mainly in the Mediterranean and temperate regions) and a very different phylogenetic position (Arthoniomycetes, Roccellaceae) (Ertz \& Tehler 2011). Sorediate morphs of Syncesia myrticola differ from the new species by a different chemistry (protocetraric acid; thallus PD+ rust-red) (Ertz et al. 2018a). Opegrapha fumosa also has a thin, inconspicuous thallus with $\mathrm{C}+$ red soralia (gyrophoric acid), but the soralia are less dense, more irregular, often elliptical, and the species occurs only in temperate regions (Coppins et al. 1992).

Etymology. The epithet refers to the unexpected taxonomic position within the Pyrenulaceae, despite morphological similarities with some species of Arthoniales. 

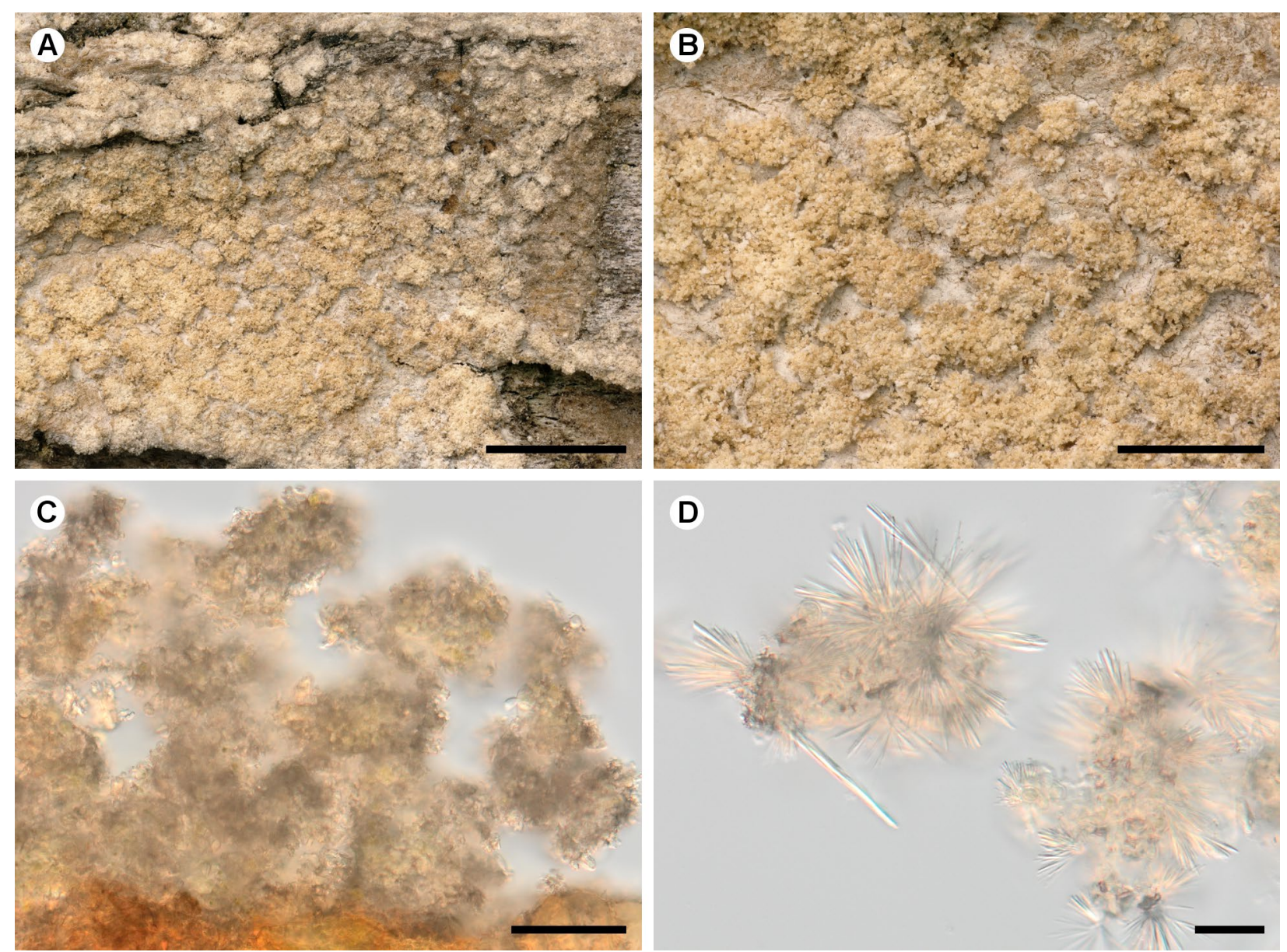

Figure 15. Serusiauxia inexpectata [holotype]. A-B - thallus, showing soralia; $\mathrm{C}$ - soredia, in K; D - soredia, showing crystals formed after addition of $\mathrm{H}_{2} \mathrm{SO}_{4}$, revealing the presence of calcium oxalate crystals. Scales: $\mathrm{A}=2.5 \mathrm{~mm} ; \mathrm{B}=1 \mathrm{~mm} ; \mathrm{C}=50 \mu \mathrm{m} ; \mathrm{D}=20 \mu \mathrm{m}$. Photos: D. Ertz.

Additional specimens examined. MAURITIUS. Pamplemousses: Same locality as type, on bark of Mangifera, 2016, Ertz 21496; ibid., 2016, Diederich 18239. Plaines Wilhems: Curepipe, Curepipe Botanic Gardens, 2019, Diederich 19200. SEYCHELLES. Mahé: W of Anse Royale, Le Jardin du Roi, parkland, on a tree, 2015, Diederich 17815 (SEY, herb. Diederich).

\section{SIPHULA Fr.}

\section{mascarena Mathey}

Plaines Wilhems: Le Pétrin, heathland NW of Pétrin Information Centre, terricolous, 2016, Diederich 18372; ibid., 2019, Ertz 23315A (TLC: thamnolic, solvents A, B'). Savanne: Road from Le Pétrin to Chamouny, beginning of trail to Montagne Cocotte, on bark, 2016, Diederich 18378; along trail to Mt Cocotte, on bark, 2019, Diederich 18843, 18874.

Previously reported from Pétrin by Mathey (1974), David \& Hawksworth (1995) and Crittenden et al. (1995).

\section{SIPMANIELLA Kalb}

sulphureofusca (Fée) Kalb [三Lecanora sulphureofusca Fée]. Reported from Mauritius by Daruty (1873).

\section{SPHAEROPHORUS Pers.}

australis Laurer $\equiv$ Bunodophoron australe

compressus Ach. [as 'Sphaerophoron compressum'] = Bunodophoron melanocarpum

\section{SPILOMA Ach.}

verrucaria Ach. 'Sur l'écorce des arbes, île Maurice' (Bélanger 1834).

\section{SPIROGRAPHA Zahlbr.}

+lichenicola (D. Hawksw. \& B. Sutton) Flakus, Etayo \& Miadlikowska

$\equiv$ Cornutispora lichenicola D. Hawksw. \& B. Sutton

A lichenicolous pycnidial fungus reported from Mauritius, 'Plains', on Haematomma collatum, 1857, Ayres (BM), by Kalb et al. (1995).

\section{SPORACESTRA A. Massal.}

\section{pertexta (Nyl.) Stapnes \& Timdal}

Rivière Noire: Trail from Plaine Champagne towards Piton de la Petite Rivière Noire, on bark, 2016, Diederich 18432, 18454 (det. Timdal).

New for Mauritius.

\section{SQUAMULEA Arup, Søchting \& Frödén}

cf. squamosa (B. de Lesd.) Arup, Søchting \& Frödén

Rivière Noire: La Preneuse (between Tamarin and Grande Rivière Noire), cemetery (south-east part with old graves), on old tombstones from c. 1850, 2016, Diederich 18394; ibid., 2019, Diederich 18682 \& Ertz 23237; Flic-en-Flac, cemetery, on historic tombs, 2019, Diederich 19553. 


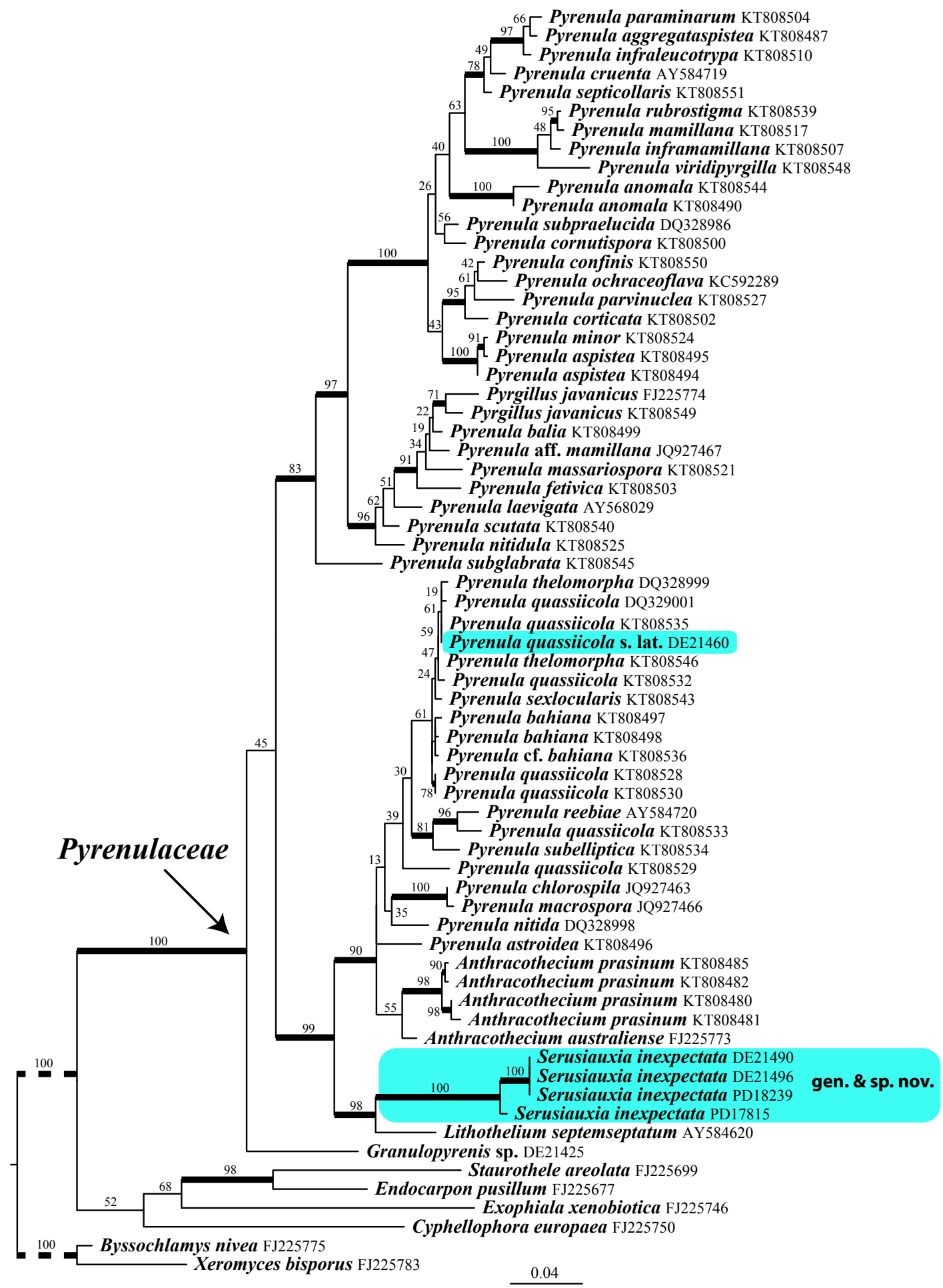

Figure 16. Phylogeny of Pyrenulaceae based on a data set of mtSSU sequences that resulted from a RAxML analysis. Maximum likelihood bootstrap values are shown above or near internal branches. Internal branches that are considered strongly supported by both RAxML and Bayesian analyses are represented by thicker lines. The newly sequenced samples from Mauritius are highlighted, and their names followed by collecting numbers of authors, which act as specimen and sequence identifiers. A newly sequenced sample of Granulopyrenis from Iles Éparses is also added. The length of the branches represented by dashed lines was reduced by $50 \%$ for editing reasons.

mtSSU and nuLSU sequences clearly place our specimen within Squamulea (Fig. 10). While our mtSSU sequence is identical to sequence KC179591 from $S$. squamosa but differs from sequence KC179592 of S. subsoluta by two nucleotides, our nuLSU sequence differs by nine nucleotides from both species. Thus, our specimen belongs either to $S$. squamosa s.lat. or to a closely related, possibly undescribed species. New for Mauritius.

\section{STEGOBOLUS Mont.}

fissus (Nyl.) A. Frisch $\equiv$ Rhabdodiscus fissus

\section{STEREOCAULON Hoffm.}

arbuscula Nyl. $\equiv$ Lepraria arbuscula

"pulchellum Wedd., in Daruty, Trans. Roy. Soc. Arts Mauritius, n.s. 7: 166 (1873), nom. nud. (description missing). 
salazinum (Bory) Fée. Reported from Mauritius, 1891, 'supra saxa vulcanica', fr. Rodriguez (Hue 1898). Specimen Daruty 93 (MAU L1976) from Le Pouce, 'sur la terre au sommet', 1873, was examined by Lamb in 1960 and annotated 'Stereocaulon sp., apparently related to $S$. sentelligerum $\mathrm{Th}$. Fr. (syn. S. salazinum Bory p. p.). Too scrappy for certain identification at present.

\section{STICTA (Schreb.) Ach.}

Simon et al. (2018) presented a phylogenetic study of the genus Sticta in Madagascar and the Mascarenes, comprising 31 endemic species. Its diversity on Mauritius was sampled by E. Sérusiaux in 2013. Following these authors, five of the endemic species of Sticta are known from Mauritius: S. dichotoma and S. macrophylla were both described from Mauritius and are also known from Reunion; S. variabilis was described from Reunion and is also known from Mauritius and Madagascar; two further unnamed species have been recognized in Mauritius. None of these species is endemic to Mauritius. Because of the 'dramatic example of the tremendous impact of human contact', these authors 'consider that a significant part of the lichen flora in Mauritius is now extinct and our study only incorporates the few surviving taxa'. The two unnamed species are called ' $S$. sp. 1' and ' $S$. sp. 10' in their phylogenetic tree. In an unpublished thesis by Simon (2015), ' $S$. sp. 1' is called Sticta pseudodiversa ad int., and ' $S$. sp. 10' is called Sticta mascarena ad int. Following that author, Sticta pseudodiversa has a thallus with rounded lobes (lobules and phyllidia lacking), lacks apothecia, and has a cyanobacterial photobiont, while $S$. mascarena has a thallus with elongated and dichotomously branching lobes with apothecia, and a green algal photobiont.

Simon et al. (2018) stated that 'Five validly published epithets are available for the species studied' in their paper. They obviously missed Sticta glaberrima Laurer, Stictina flavireagens Gyeln. [see comments below] and Stictina robillardii Dodge, all described from Mauritius. Three further infraspecific taxa have been described from Mauritius: Sticta damicornis var. fucoides Laurer, S. damicornis var. polita Laurer and $S$. dichotoma var. pendula Bory ex Delise.

Duplicates of all our 2016 specimens are kept in LG, and most of these have been sequenced (indicated below by 'DNA' followed by the sequence number). A. Simon kindly sent us identifications of the sequenced specimens.

ambavillaria (Bory) Ach. Reported from Pétrin rainforest and Le Pouce, 600 m, 2001, by Holm \& Gregersen (2002).

argyracea Delise $\equiv$ Pseudocyphellaria argyracea

argyracea f. insidiata (Nyl. ex Cromb.) Zahlbr. = Pseudocyphellaria argyracea

aspera Laurer $=$ Pseudocyphellaria argyracea

aurata Ach. $\equiv$ Crocodia aurata

aurigera var. nuda Delise $=$ Pseudocyphellaria crocata

cometia Ach. Reported from Mauritius by Laurer (1827).

crocata (L.) Ach. $\equiv$ Pseudocyphellaria crocata

cyphellulata (Müll. Arg.) Hue

Reported from Bedrock $\left(20^{\circ} 19^{\prime} 02^{\prime \prime} \mathrm{S}, 57^{\circ} 26^{\prime} 78^{\prime \prime} \mathrm{E}\right)$ and Le Pouce, 600 m, 2001, by Holm \& Gregersen (2002). Other unpublished specimens, collected by Krog \& Timdal in 1991 in Mt Cocotte, Plaine Champagne towards Piton de la Petite Rivière Noire, Curepipe (Trou au Cerfs), between Pétrin and Mt Brise Fer, Macchabee Kiosk, along the road from Bois Chéri to Grand Bassin, are kept in O.

damicornis (Sw.) Ach. ['damaecornis' and 'damaecornem' are orthographic variants]. Reported from Mauritius (herb. Lenormand) by Laurer (1827), Nylander (1859) and Daruty (1873), and 'Sur les arbres et les rochers, aux îles Maurice et de Bourbon' by Bélanger (1834). Following Moncada et al. (2018), although the name Sticta damicornis has frequently been used for Sticta specimens from most continents, the species appears to occur only in the Caribbean.

"damicornis [as 'damaecornis'] var. fucoides Laurer, Linnaea 2: 42 (1827). Type: 'In Insula St. Mauritii', Sieber 38 p.p. (FH) (Laurer 1827, Dodge 1964: 193).

damicornis var. macrophylla Nyl. Reported from Mauritius by Daruty (1873).

damicornis var. polita Laurer $=$ ? Sticta dichotoma

\section{*dichotoma (Bory) Delise}

Hist. Lich. Sticta: 107 (1825); $\equiv$ Pulmonaria dichotoma Bory in Flörker, Magazin Ges. naturf. Fr. Berlin 2: 127 (1809). Type: 'An Bäumen auf der Insel Frankreich [Mauritius] und Reunion', Bory de Saint-Vincent (PC-Thuret, lectotype, selected by Galloway 1995).

${ }^{*}=$ ? Sticta dichotoma var. pendula Delise, Hist. Lich. Sticta: 108 (1825). Type: 'dans les bois de l'île de France [Mauritius]', Bory de Saint-Vincent (PC-Lenormand, holotype) (Galloway 1995).

${ }^{*}=$ ? Sticta damicornis [as 'damaecornis'] var. polita Laurer, Linnaea 2: 42 (1827); 三Stictina polita (Laurer) Dodge, Beih. Nova Hedwigia 12: 195 (1964). Type: 'In Insula St. Mauritii', Sieber, Pl. Crypt. Exot. 38 p. p. (sub. S. damaecornis var. platyphylla) (FH, ex herb. Merrill) (Dodge 1964, Laurer 1827). Following the description given by Dodge (1964), this might be a synonym of $S$. dichotoma.

*=?Sticta glaberrima Laurer, Linnaea 2: 42 (1827). Type: 'Ad arborem cortices Insulae St. Mauritii', 1826, Sieber (G 00294732, FH, isotypes) (Laurer 1827, Dodge 1964: 183). Following a redescription by Dodge (1964), based on the FH specimen, and a photo at http://www.ville-ge.ch/musinfo/ bd/cjb/chg/adetail.php?id=241516\&base=img\&lang=en, this might be a synonym of $S$. dichotoma .

${ }^{*}=$ ? Sticina robillardii Dodge [as 'robillardi'], Beih. Nova Hedwigia 12: 196 (1964). Type: Mauritius, Robillard (FH). Following the original description, this might be a synonym of Sticta dichotoma.

Rivière Noire: Trail from Plaine Champagne towards Piton de la Petite Rivière Noire, on bark, 2016, Diederich 18425 (dupl. LG, DNA 6222).

Also reported from Mauritius by Swinscow \& Krog (1988), Le Pouce, 600 m, 2001, by Holm \& Gregersen (2002), Mauritius, 2013, Sérusiaux 3448 (LG) by Simon (2015) and Simon et al. (2018), and Mt des Créoles, 1991, Krog \& Timdal (O) by Lücking \& Timdal (2016: 198). Further unpublished reliable herbarium specimens from Le Pouce (1873, Daruty, MAU L1977, det. Krog), Piton de la Petite Rivière Noire, Mt Corps de Garde, Le Pouce and Mt Cocotte, collected by Krog \& Timdal in 1991, are kept in O.

dichotoma var. pendula Bory ex Delise $=$ ? Sticta dichotoma

faveolata var. cervicornis (Nyl.) Zahlbr. Reported from Mauritius, 'auf Rinde', by Lindau (1908). 
${ }^{*}$ )Sticta flavireagens (Gyeln.) Diederich \& Ertz, comb. nov.

(Fig. 17)

Basionym: Stictina flavireagens Gyeln., Repert. Spec. Nov. Regni Veg. 29: 4 (1931). Type: Mauritius, Sieber 51 (W 2010-00530, holotype!).

MycoBank MB 834933

Description. Thallus rosette-forming to irregularly spreading, several cm diam., closely attached centrally, without basal holdfast, margins \pm free, not visibly ascendant. Lobes $6-15 \mathrm{~mm}$ broad, at least $2 \mathrm{~cm}$ long, rounded, \pm discrete at margins, contiguous. Margins rounded to irregular, incised, not thickened, phyllidiate and ciliate, not isidiate. Upper surface medium slate blue to olivaceous, rather even, without maculae, pseudocyphellae, isidia, phyllidia or soralia. Marginal phyllidia minute, initially almost digitiform (but not originating from isidia), soon becoming broader and flat, thallus-like, squamiform, rounded or more often incised, reaching $1-2 \mathrm{~mm}$ in diam. Marginal cilia sparse, ochraceous, $0.15-0.5 \mathrm{~mm}$ long, either simple and 20-30 $\mu \mathrm{m}$ thick or splitting and reaching $60 \mu \mathrm{m}$. Medulla white, $\mathrm{K}+$ yellow (TLC not performed on type specimen). Photobiont cyanobacterial. Lower surface in marginal $1.5-3 \mathrm{~mm}$ ochraceous, slightly tomentose to occasionally glabrous, \pm smooth, tomentum concolorous to lower surface; centrally dark brown, densely tomentose, tomentum shaggy, densely entangled, medium to dark brown, occasionally with anchoring bundles or tufts of rhizines. Cyphellae common, round to irregular, $0.1-0.7 \mathrm{~mm}$ diam., deeply urceolate; margins narrow, raised, sharply defined, $\sim 20 \mu \mathrm{m}$ thick, concolorous with lower surface, free of tomentum; basal membrane white. Apothecia not seen.

Notes. Sticta flavireagens is mainly characterized by the cyanobacterial photobiont, the rosette-forming thallus without basal holdfast, the $\mathrm{K}+$ yellow medulla, the absence of apothecia, the thallus surface devoid of maculae, pseudocyphellae, isidia, phyllidia or soralia, and the margin with both phyllidia and cilia.

Sticta diversa (Stirt.) Zahlbr. is one of the rare species from the genus with a $\mathrm{K}+$ yellow-orange medulla. The epithet 'pseudodiversa' chosen for an undescribed species from Mauritius (Simon 2015) is based on similar morphology and chemistry. We collected several specimens in Mauritius belonging to $S$. pseudodiversa. As Gyelnik (1931a) described the new species $S$. flavireagens from Mauritius, mainly distinguished by the $\mathrm{K}+$ yellow medulla, we wondered if Gyelnik's name might represent an earlier name for Simon's new S. pseudodiversa. An examination of the holotype kept in $\mathrm{W}$ showed a similar species, distinguished from our Mauritius specimens and from $S$. diversa by at least two characters: (1) marginal phyllidia are present but isidia are lacking (vs. flattened to coralloid marginal isidia are abundant); (2) the margin presents isolated cilia (such cilia are lacking in our specimens and in $S$. diversa).

We conclude that our specimens do not belong to Sticta flavireagens. As Sieber's herbarium specimens sometimes have wrong locality annotations (e.g., see discussion under Cora gyrolophia), it is even uncertain whether Sieber's specimen originates from Mauritius, or possibly from the Antilles (as suggested for C. gyrolophia) or another country. Nevertheless, $S$. flavireagens seems to be a distinct species that needs to be combined in Sticta. The species should be searched for in Mauritius and in the Neotropics. Only when more specimens become available will it be possible to determine whether the annotation 'Mauritius' is accurate or an error. Dodge (1964: 188) gave a new description of the species based on a Mauritius specimen from Sieber, kept in FH (sub S. variabilis).

fragillima Bab. [三 Stictina fragillima (Bab.) Nyl.] Reported from Mauritius by Daruty (1873).

glaberrima Laurer $=$ ? Sticta dichotoma

\section{"macrophylla Bory ex Delise}

in Delise, Hist. Lich. Sticta: 110 (1825); 三 Stictina macrophylla (Bory ex Delise) Nyl., Flora 52: 111 (1869). Type: 'Ile de France, dans les bois assez clairs', Bory de Saint-Vincent (PC-Thuret, lectotype, selected by Galloway 1995).

Rivière Noire: Trail from Plaine Champagne towards Piton de la Petite Rivière Noire, on bark, 2016, Diederich 18450 (dupl. LG, DNA 6219), 18459 (dupl. LG, DNA 6220).

Previously reported from Ile de France (Mauritius), dans les bois assez clairs, 1801, by Delise (1825), 'Sur les rochers, aux îles Maurice et de Bourbon' by Bélanger (1834), Mauritius, Robillard (FH) by Dodge (1964: 190), Le Pouce, 600 m, 2001, by Holm \& Gregersen (2002), 2013, Sérusiaux $3445,3452,3454$ (LG) by Simon (2015) and Simon et al. (2018), and Bambou Mountains and viewpoint WNW of Mt Cocotte, 1991, Krog \& Timdal (O), by Lücking \& Timdal (2016: 192, 194). Further unpublished reliable herbarium specimens from Piton de la Petite Rivière Noire, Le Pouce, Macchabee Forest and Macchabee Kiosk, collected by Krog \& Timdal in 1991, are kept in O.

macrophylla var. badia Delise [三Stictina macrophylla f. badia (Delise) Müll. Arg.]. Reported from Mauritius, Robillard (FH) by Dodge (1964: 190).

\section{*mascarena Simon ined.}

Les photomorphes au sein des Lobariaceae (Peltigerales, Ascomycota): 9 (2015).

Rivière Noire: Trail from Plaine Champagne towards Piton de la Petite Rivière Noire, on bark, 2016, Diederich 18452 (dupl. LG, DNA 6213), 18460 (dupl. LG, DNA 6214).

Reported from Mauritius, 2013, Sérusiaux 3447, 3453 (LG) by Simon (2015) and Simon et al. (2018, sub 'Sticta sp. 10').

mougeotiana Delise $=$ Pseudocyphellaria crocata

nylanderiana Zahlbr. $=$ Dendriscosticta platyphylla

orygmaea Ach. $\equiv$ Pseudocyphellaria orygmaea

$\left(^{*}\right)$ plumbea Moug. ex Delise. This species was initially described from Reunion and Mauritius ('dans les bois des îles de France et Bourbon'). Galloway (1995) lectotypified the name on a specimen from PC-Lenormand. Following Simon et al. (2018), the species exists only in Reunion.

\section{"pseudodiversa Simon ined.}

Les photomorphes au sein des Lobariaceae (Peltigerales, Ascomycota): 9 (2015).

Rivière Noire: Trail from Plaine Champagne towards Piton de la Petite Rivière Noire, on bark, 2016, Diederich 18437 (dupl. LG, DNA 6218), 18442 (dupl. LG, DNA 6217).

Reported from Mauritius, 2013, Sérusiaux 3450 (LG) by Simon (2015) and Simon et al. (2018, sub 'Sticta sp. 1').

pulmonacea (Ach.) Ach. = Lobaria pulmonaria

rigidula Delise [三 Stictina rigidula Nyl.]. Reported from Mauritius by Daruty (1873). 

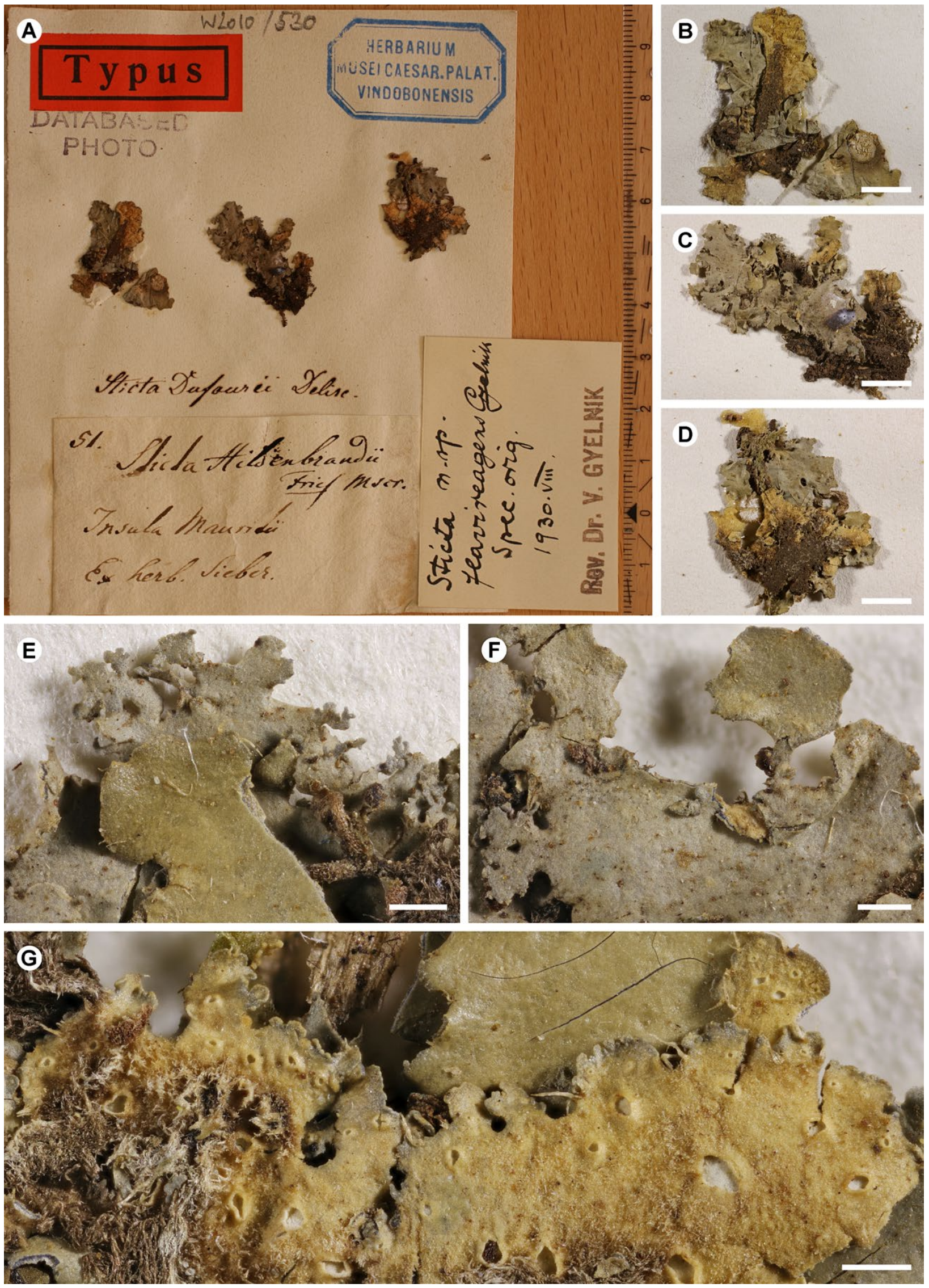

Figure 17. Sticta flavireagens [W, holotype]. A - type specimen; B - left thallus; C - middle thallus; D - right thallus; E-F - upper surface of thallus, showing marginal phyllidia; $\mathrm{G}-$ lower surface of thallus, showing marginal cilia. Scales: $\mathrm{B}-\mathrm{D}=5 \mathrm{~mm} ; \mathrm{E}-\mathrm{G}=0.5 \mathrm{~mm}$. Photos: P. Diederich. 


\section{tomentosa (Sw.) Ach.}

Reported from Mauritius, 'auf Rinde', by Lindau (1908), from the road between Mt Cocotte and Bassin Blanc, 1991, Krog \& Timdal (O), by Lücking \& Timdal (2016: 194), and from Le Pouce, 600 m, 2001, by Holm \& Gregersen (2002). Further unpublished specimens from Mt Cocotte, collected by Krog \& Timdal in 1991, are kept in O. Simon (2015) and Simon et al. (2018) did not confirm the presence of this species in Mauritius.

variabilis Ach.

\section{= Sticta papyracea Delise}

Rivière Noire: Trail from Plaine Champagne towards Piton de la Petite Rivière Noire, on bark, 2016, Diederich 18418 (dupl. LG), 18427 (dupl. LG, DNA 6221).

Previously reported from Mauritius, 'auf Rinde', by Lindau (1908), Pétrin rainforest and Le Pouce, 600 m, 2001, by Holm \& Gregersen (2002, as S. papyracea), 2013, Sérusiaux 3451 (LG) by Simon (2015) and Simon et al. (2018), 'herb. Lenormand' by Nylander (1859: 254), and by Galloway (2001: 97). Further unpublished reliable herbarium specimens are available from Curepipe (1933, Vaughan, MAU L42, det. Krog) and from Piton de la Petite Rivière Noire, Le Pouce and Mt Cocotte (1991, Krog \& Timdal, O). One of our specimens (Diederich 18427) has been sequenced and identified as $S$. variabilis by Simon (pers. comm.). Our other specimen (Diederich 18418) is morphologically similar and provisionally kept under the same name.

variabilis f. linearifolia Nyl. Reported from Mauritius (herb. Lenormand) by Nylander (1859).

aff. weigelii (Ach.) Vain.

Plaines Wilhems: Curepipe, Curepipe Botanic Gardens, on bark, 2016, Diederich 18301 (dupl. LG, DNA 6215). Rivière Noire: Trail from Plaine Champagne towards Piton de la Petite Rivière Noire, on bark, 2016, Diederich 18424 (dupl. LG). Reported from Mt des Créoles, between Mt Cocotte and Bassin Blanc and Bambou Mountains, 1991, Krog \& Timdal (O) by Lücking \& Timdal (2016: 192, 194, 198, as S. weigelii s.lat.), from Plaines Champagne, at viewpoint of Black River Gorge, on bark, 1990, Hawksworth (K-IMI) by Crittenden et al. (1995), and from Bedrock $\left(20^{\circ} 19^{\prime} 02^{\prime \prime} \mathrm{S}\right.$, $57^{\circ} 26^{\prime} 78^{\prime \prime} \mathrm{E}$ ), Pétrin rainforest and Le Pouce, $600 \mathrm{~m}, 2001$, by Holm \& Gregersen (2002, as $S$. cf. weigelii).

One of our specimens (Diederich 18301) has been sequenced and identified as $S$. aff. weigelli by Simon (pers. comm.), the uncertainty being due to the missing sequences of $S$. weigelii s.str. The other specimen (Diederich 18424) is morphologically similar and obviously represents the same species.

Simon (2015) and Simon et al. (2018) did not confirm the presence of this species in Mauritius, and the previously reported specimens should also be compared with the morphologically similar S. pseudodiversa.

Further unpublished specimens from Le Pouce and Curepipe Botanical Garden, collected by Krog \& Timdal in 1991 and named $S$. weigelii, are kept in $\mathrm{O}$.

\section{STICTINA Nyl.}

argyracea f. insidiata $\mathrm{Nyl} .=$ Pseudocyphellaria argyracea

dissimilis Nyl. $\equiv$ Pseudocyphellaria dissimilis

flavireagens Gyel. $\equiv$ Sticta flavireagens

fragillima (Bab.) Nyl. $\equiv$ Sticta fragillima macrophylla (Bory ex Delise) Nyl. $\equiv$ Sticta macrophylla

macrophylla f. badia (Delise) Müll. Arg. 三 Sticta macrophylla var. badia

nylanderiana (Zahlbr.) Dodge $=$ Dendriscosticta platyphylla

polita (Laurer) Dodge $\equiv$ Sticta damicornis var. polita

rigidula $\mathrm{Nyl} . \equiv$ Sticta rigidula

robillardii Dodge $=$ ? Sticta dichotoma

strictula (Delise) Nyl. Reported from Mauritius, Andersson, 1855 (FH), by Dodge (1964: 198), and from Mauritius by Hue (1892: 91).

\section{STRIGULA Fr.}

elegans (Fée) Müll. Arg. = Strigula smaragdula

elegans var. stellata (Nyl. \& Cromb.) R. Sant. $\equiv$ Strigula smaragdula var. stellata

\section{smaragdula Fr.:Fr.}

* $=$ Phyllocharis elegans Fée, Essai Crypt. Ecorc. 1 (1-7): 94, 100 (1824); 三 Strigula elegans (Fée) Müll. Arg., Flora 63: 41 (1880). Type: 'in insula Franciae, supra folia arborum', Petit-Thouars (G 00292267, holotype) (Santesson 1952: 169).

Rivière Noire: Chamarel, Ebony Forest, SW part of forest, on leaves, 2019, Ertz 23640.

smaragdula var. stellata (Nyl. \& Cromb.) Farkas $\equiv$ S. elegans var. stellata (Nyl. \& Cromb.) R. Sant. Mauritius, Commerson (L, on n. 491 Erythrospermum lanceolatum) (Santesson 1952: 172).

\section{SYNECHOBLASTUS Trevis.}

coilocarpus Müll. Arg. $\equiv$ Collema coilocarpum

robillardii Müll. Arg. =? Collema leptaleum var. leptaleum

\section{TELOSCHISTES Norman}

flavicans (Sw.) Norman

$=$ Physcia flavicans f. crocea (Ach.) Cromb.

Reported from Rodrigues, on branches of trees, 1874, Balfour 2253 (BM) by Crombie (1876b) and Almborn (1989). Further unpublished specimens identified by Krog from Mt Corps de Garde are kept in MAU, O and US.

\section{TEPHROMELA M. Choisy}

\section{atra (Huds.) Hafellner}

$\equiv$ Lecanora atra (Hudson) Ach.

${ }^{*}=$ ? Lecanora atra f. succedanea Nyl., in Crombie, Journ. Linn. Soc., Bot. 15: 440 (1876). Type: Rodrigues, on bark of trees, dead wood and on rocks, 1874, Balfour 2207, 2292 (BR 5030073484648) (Crombie 1876b).

Port Louis and Moka: Along trail from Moka to Le Pouce, on bark, 2019, Ertz 24081.

Previously also reported from Mauritius by Daruty (1873).

THALLOIDIMA A. Massal.

*ayresianum Müll. Arg., Hedwigia 31: 280 (1892); 三 Toninia ayresiana (Müll. Arg.) Zahlbr., Cat. Lich. Univ. 4: 262 (1926 ['1927']). Type: 'Ravine of Grand River, ad terram', Febr. 1857, Ayres (BM, holotype; G 00047510, isotype) (Müller 1892). 
Following Timdal (1991: 120), 'The holotype in BM is very poor and did not allow thorough examination. A few poorly developed apothecia were present, but asci and well developed paraphyses were not found. The morphology of the thallus did not resemble any known Toninia species, however, but resembles Lecidea lurida or Solenopsora holophaea.'

\section{THECARIA Fée}

\section{quassiicola Fée}

Plaines Wilhems: Curepipe, Trou aux Cerfs, along road surrounding the crater, on bark, 2016, Diederich 18277.

New for Mauritius.

\section{THELOTREMA Ach.}

"affine Wedd., in Daruty, Trans. Roy. Soc. Arts Mauritius, n.s.

7: 166 (1873), nom. nud. (description missing).

bahianum (Ach.) Ach. $\equiv$ Ocellularia bahiana

bonplandii Fée $\equiv$ Ocellularia bonplandii

cavatum Ach. $\equiv$ Ocellularia cavata

diplotrema Nyl. This species was described by Nylander (1859: 258) from Reunion. Later this was inadvertently cited as 'Mauritius' (Dodge 1964: 93). The report from Mauritius is therefore erroneous.

olivaceum (Fée) Mont. $\equiv$ Myriotrema olivaceum

TOMASELLIA A. Massal.

eschweileri (Müll. Arg.) R. C. Harris $\equiv$ Mycoporum eschweileri zollingeri Müll. Arg., see under Celothelium

TONINIA A. Massal.

ayresiana (Müll. Arg.) Zahlbr. 三 Thalloidima ayresianum

TRYPETHELIUM Spreng.

cruentulum Nyl. = Pyrenula cruenta

cruentum Mont. $\equiv$ Pyrenula cruenta

sprengelii Ach. Reported from Mauritius by Daruty (1873).

USNEA Dill. ex Adans.

articulata (L.) Hoffm. [三 Usnea barbata var. articulata (L.) Ach.]. Reported from Mauritius by Daruty (1873).

baileyi (Stirt.) Zahlbr.

= Usnea implicata (Stirt.) Zahlbr.

Reported from Mauritius [almost surely Rodrigues], 1874, Balfour (W) (Motyka 1936: 62), from Savanne, Plaine Champagne, near viewpoint WNW of Mt Cocotte, 1991, Krog \& Timdal (O) (Lücking \& Timdal 2016: 194). Also from Mauritius (Crittenden et al. 1995, as Usnea cf. bailyi). Further unpublished specimens from Piton de la Petite Rivière Noire, Le Pouce, Curepipe (Trou aux Cerfs), Pétrin heath, Macchabee Forest and Mt Cocotte, collected by Krog \& Timdal in 1991, are kept in O.

barbata var. articulata (L.) Ach. $\equiv$ Usnea articulata

barbata var. ceratina (Ach.) Schaer. $\equiv$ Usnea ceratina

barbata var. hirta (L.) Fr. $\equiv$ Usnea hirta

barbata var. sorediuscula Müll. Arg. Reported from Mauritius, 'an Ästen', by Lindau (1908). ceratina Ach. [三Usnea barbata var. ceratina (Ach.) Schaer.]. Reported from Mauritius by Daruty (1873).

contorta Jatta. Reported from Mauritius, Robillard (WRSL) and Sieber (W) by Motyka (1938: 415). Stevens (1990) examined a specimen named U. contorta from Madagascar and concluded that it belongs to $U$. himantodes. However, no type material of $U$. contorta was available, hence the synonymy could not be established.

*dasypogoides Nyl. ex Cromb., J. Bot. 14: 263 (1876). Type: Rodrigues, on the trunks and branches of trees, 1874, Balfour 521, 524, 2323 (syntypes: G 00294017; H 9505016, 9505017, 9505018; E 00456467) (Crombie 1876a, b). A specimen named $U$. dasypogoides, collected by Rodriguez in Mauritius in 1892, is kept in BR (5030062526632).

distensa Stirt. Reported from Mauritius (FH, sub U. plicata) by Dodge (1957: 65).

eburnea Motyka. Reported from Mauritius by Dodge (1956: 391).

exasperata (Müll. Arg.) Mot. This name refers to an assemblage of several African species for which no taxonomic and phylogenetic revision is available yet. Specimens inhabited by the new Biatoropsis millanesiana, provisionally called $U$. exasperata s. 1. (see above), need further study.

florida (L.) Weber ex F. H. Wigg. [三 Lichen floridus L.]. Reported from Mauritius by Flörke (1809) and from Rodrigues, on branches of trees, 1874, Balfour 2355 (Crombie 1876b).

\section{* fuscorubens Motyka}

Lich. Gen. Usnea Stud. Monogr. 2: 546 (1938). Type: Mauritius, Simony (W Krypto 1896-0009211, holotype) (fide Dodge 1957: 34).

Also reported from Pouce (W) by Motyka (1938: 547). This species has been accepted, described and illustrated by Ohmura $(2001,2012)$.

gracilis Ach. Reported from Mauritius (FH, sub U. plicata) by Dodge (1957: 21)

\section{himantodes Stirt.}

Reported from Savanne, Plaine Champagne, near viewpoint WNW of Mt Cocotte, 1991, Krog \& Timdal (O-L-22003) by Lücking \& Timdal (2016: 194). Further unpublished specimens from Piton de la Petite Rivière Noire, Mt Corps de Garde, Macchabee Forest, Le Pouce, Pétrin heath, Bassin Blanc and Tamarin Falls, collected by Krog \& Timdal in 1991, are kept in O.

hirta (L.) Weber ex F. H. Wigg. [三 Usnea barbata var. hirta (L.) Fr.]. Reported from Mauritius by Daruty (1873) and 'an Rinde' by Lindau (1908).

implicata (Stirt.) Zahlbr. = Usnea baileyi

longissima Ach. Reported from Mauritius by Hue (1892: 63).

luteola Motyka. Reported from Mauritius, Reduit, corticole, Orian 3 (K) by Dodge (1957: 40).

\section{nidifica Taylor}

*=Usnea straminea Müll. Arg., Flora 42: 162 (1879). Type: Mauritius, Robillard (FH 00302078, G 00066397, G 00294016, G 00294019, G 00294020, G 00294021, TUR V490) (Dodge 1957).

Following Stevens (1991, 1999: 69), U. straminea is most probably a synonym of $U$. nidifica, as it shares the same chemistry (TLC: salazinic, norstictic and protocetraric 
[trace], identified by Krog in the FH specimen, see https:// kiki.huh.harvard.edu/databases/specimen search.php?mode $=$ details\&id $=220974$ ) and a very similar morphology. It was also reported from Rodrigues, 1874 ('1872'), Balfour (G) by Motyka (1938: 467).

promontorii Motyka. Reported from Mauritius, Sieber 43 (FH, sub U. plicata) by Dodge (1957: 66).

pulvinata Fr. Reported from Mauritius, Robillard (FH, sub U. florida var. strigosa) by Dodge (1957: 52).

\section{rubicunda Stirt.}

Plaines Wilhems: Curepipe Botanic Gardens, on bark, 2019, Diederich 19458.

Also reported from Mauritius by Crittenden et al. (1995, as Usnea rubicunda gr.), and from Mt des Créoles and Plaine Champagne, near viewpoint WNW of Mt Cocotte, 1991, Krog \& Timdal (O) by Lücking \& Timdal (2016: 194, 198). Further unpublished specimens from Tamarin Falls, Le Pouce, Pétrin heath and Macchabee Forest, collected by Krog \& Timdal in 1991, are kept in O.

straminea Müll. Arg. = Usnea nidifica

trichodea Ach. Reported from Mauritius by Hue (1892: 64).

trichodeoides Vain. ex Motyka

Occurs in Mauritius, following Stevens (1991: 60, distribution map).

\section{VARICELLARIA Nyl.}

velata (Turn.) Schmitt \& Lumbsch [三 Pertusaria velata (Turn.) Nyl.]. Reported from Mauritius by (Daruty 1873), and from Rodrigues, on branches of trees, 1874, Balfour 2215, by Crombie (1876b).

\section{VERRUCARIA Schrad.}

*atacta Bél., Voyage aux Indes-orientales, pendant les années 1825-1829: 141 (1834). Type: 'Sur l'écorce des arbres de la montagne du Pouce, à l'île de France' (Bélanger 1834) (PC 0019216).

chlorotica Ach. $\equiv$ Porina chlorotica

denudata Nyl. $\equiv$ Anthracothecium denudatum

gemmata (Ach.) Ach. $\equiv$ Acrocordia gemmata

macrozoma Fée $=$ Astrothelium phlyctaena

mamillana Ach. $\equiv$ Pyrenula mamillana

marginata $($ Hook. f.) Hepp = Pyrenula mamillana

nitida (Weigel.) Schrad. $\equiv$ Pyrenula nitida

planorbis Ach. $\equiv$ Constrictolumina planorbis

quinqueseptatula Nyl. ex Cromb. 三Arthopyrenia quinqueseptatula

thelena Ach. $\equiv$ Bogoriella thelena

tropica Ach. $\equiv$ Nigrovothelium tropicum

\section{VIRIDOTHELIUM Lücking, M. P. Nelsen} $\&$ Aptroot

\section{tricolor Lücking, M. P. Nelsen \& N. Salazar}

Plaines Wilhems: Le Pétrin, between Pétrin Information Centre and first viewpoint along trail to the west, on bark, 2016, Diederich 18351.
The specimen is in poor condition, with almost all perithecia overmature. A single mature perithecium has been examined microscopically. Ascospores are 125-188 × 34-52 $\mu \mathrm{m}$, slightly larger than in the original description $(120-150 \times$ $30-40 \mu \mathrm{m})$. The black perithecia surrounded by a white area contrasting with the pale brown thallus (cf. epithet 'tricolor') are characteristic for the species. Previously known from Panama and Venezuela (Lücking et al. 2016). New for Africa and for the Paleotropics.

\section{XANTHOPARMELIA (Vain.) Hale}

conspersa (Ehrh. ex Ach.) Hale [三 Parmelia conspersa (Ehrh. ex Ach.) Ach.]. Reported from Mauritius by Daruty (1873) and (Lindau 1908), 'Sur les rochers, à l'île Maurice' by Bélanger (1834) (PC 0018308), and from Round Island, rocks on hillside, $450 \mathrm{ft}$, by Johnston (1894: 263).

\section{phaeophana (Stirt.) Hale}

*= Parmelia subfuscescens Nyl., Parmeliae exoticae novae, Flora 68: 613 (1885). Type: Mauritius (H-NYL, lectotype) (Dodge 1959: 80; Hale 1990: 171).

${ }^{*}=$ Parmelia wightii Dodge, Ann. Missouri Bot. Gard. 46: 69 (1959). Type: Mauritius, saxicole?, R. Wight (FH-Taylor, holotype) (Dodge 1959: 56, 69-70; Hale 1990: 173).

Rivière Noire: La Preneuse (between Tamarin and Grande Rivière Noire), cemetery (SE part with old graves), on old tombstones from c. 1850, 2016, Diederich 18390 (det. Masson; TLC: usnic, succinprotocetraric, fumarprotocetraric, physodalic).

Also reported from Pouce range, saxicole, Ayres (K) (Dodge 1959: 70), and from Round Island, $290 \mathrm{~m}$, saxicole, Johnston 27, 29 (K) (Dodge 1959: 70). Further unpublished specimens from Morne Brabant, Mt Signal and Tamarin, collected by Krog \& Timdal in 1991, are kept in O.

subconspersa (Nyl.) Hale [三 Parmelia subconspersa Nyl.]. Reported from Rodrigues, on rocks, 1874, Balfour 2220, by Crombie (1876b).

subfuscescens (Nyl.) Hale [三 Parmelia subfuscescens Nyl.]. Reported from Mauritius by Daruty (1873), Hue (1898: 76) and Dodge (1959: 80).

subramigera (Gyeln.) Hale

= Parmelia subhypoclysta Dodge

Reported from Mauritius (K-Hooker) by Dodge (1959: 64). Further unpublished specimens from Mt Corps de Garde, Le Pouce and Mt Signal, collected by Krog \& Timdal in 1991, are kept in O.

Parmelia zeyheri Dodge. Reported from Mauritius, Pouce Range, on stones and trunks of trees, Ayres (K), by Dodge (1959: 132). Belongs to Xanthoparmelia but has never been combined there.

\section{ZWACKHIA Körb.}

bonplandii (Fée) Ertz [三 Opegrapha bonplandii Fée]. Reported from Mauritius by Daruty (1873, as $O$. 'bomplandii').

\section{Acknowledgements}

We wish to warmly thank all those who helped us to make our collecting trips to Mauritius and Rodrigues a full success, who kindly provided us with the necessary permits and who guided us during our excursions, especially Cláudia Baider and 
Kersley Pynee (The Mauritius Herbarium, Réduit) and Vincent Florens (University of Mauritius, Réduit), Kevin Ruhomaun, Parmananda Ragen and Mario Allet (National Parks and Conservation Service, Réduit), Zayd Jhumka (Forestry Service, Curepipe), Owen Griffiths (owner of Ebony Forest, Chamarel, and François Leguat Giant Tortoises Reserve and Cave, Rodrigues), Nicolas Zuel, Christabelle Duhamel and Christine Griffiths (Ebony Forest, Chamarel), Richard Payendee (Commissioner for Environment, Rodrigues), Stephen Kirsakye (Mauritian Wildlife Foundation, Rodrigues) and Laurent Schley (Administration de la nature et des forêts, Luxembourg).

We are grateful to the colleagues who helped us with identifications or advised us on species from certain taxonomic groups: Teuvo Ahti (Helsinki; Cladonia), Ingvar Kärnefelt (Lund; Cladia), Martin Kukwa (Gdańsk; Lepra, Lepraria), Nicolas Magain (Liège; Physma), Didier Masson (Bordeaux; Parmotrema, Xanthoparmelia), Ana Millanes (Madrid) and Mats Wedin (Stockholm) (Biatoropsis), Antoine Simon (Liège; Sticta), Anders Tehler (Stockholm; Roccella, Roccellina), Einar Timdal (Oslo; Krogia, Phyllopsora, Sporacestra) and Ulrik Søchting (Copenhagen, literature on Mauritius). We warmly thank the curators of BM and $\mathrm{W}$ for the loan of specimens in their care, Cyrille Gerstmans for his technical assistance with Figures 3, $11 \& 15$, Wim Baert for his help with the molecular work, and two anonymous referees for their very helpful comments on the manuscript.

The specimens were collected and transported under permits FD No. 971/A/III (Forestry Service, Curepipe, 25 July 2016), NP57/1 V5 (National Parks and Conservation Service, Réduit, 28 July 2016) and 93999 AW/gp (Ministère de l'environnement, du climat et du développement durable, Luxembourg, 10 Sept. 2019).

\section{References}

Note: For all publications referring to lichens from Mauritius, the species reported are given in square brackets.

Aguirre-Hudson, B. 1991. A taxonomic study of the species referred to the ascomycete genus Leptorhaphis. Bulletin of the British Museum (Natural History), Botany 21: 85-192. [Tomasellia zollingeri]

Ahti, T. 1977. The Cladonia gorgonina group and C. gigantea in East Africa. The Lichenologist 9: 1-15. [Cladonia gigantea]

Ahti, T. 2000. Cladoniaceae. Flora Neotropica 78, Organization for Flora Neotropica and New York Botanical Garden, Bronx.

Ahti, T. \& Aptroot, A. 1992. Lichens of Madagascar: Cladoniaceae. Cryptogamie, Bryologie-Lichénologie 13: 117-124. [Cladonia confusa, C. varians]

Ahti, T., Krog, H. \& Swinscow, T. D. V. 1987. New or otherwise interesting Cladonia species in East Africa. Annales Botanici Fennici 24: 85-94. [Cladonia varians]

Ahti, T., Dixit, P. K., Singh, K. P. \& Sinha, G. P. 2002. Cladonia singhii and other new reports of Cladonia from the Eastern Himalayan Region of India. The Lichenologist 34: 305-310.

Akaike, H. 1973. Information theory and an extension of the maximum likelihood principle. In: Petrov, B. N. \& Csaki, F. (eds), Proceedings of the 2nd International Symposium on Information Theory, pp. 267-281. Budapest: Akademiai Kiado.

Almborn, O. 1989. Revision of the lichen genus Teloschistes in central and southern Africa. Nordic Journal of Botany 8: 521-537. [Teloschistes flavicans]

Aptroot, A. 2012. A world key to the species of Anthracothecium and Pyrenula. The Lichenologist 44: 5-53.

Aptroot, A. \& Lücking, R. 2016. A revisionary synopsis of the Trypetheliaceae (Ascomycota: Trypetheliales). The Lichenologist 48: 763-982. [Bogoriella leuckertii]
Aptroot, A. \& van den Boom, P. P. G. 1998. Pyrenocollema chlorococcum, a new species with a chlorococcoid photobiont from zinc-contaminated soils and wood. Cryptogamie, Bryologie-Lichénologie 19: 193-196.

Aptroot, A., Schumm, F. \& Cáceres, M. E. S. 2012. Six new species of Pyrenula from the tropics. The Lichenologist 44: 611-618.

Aptroot, A., Cáceres, M. E. S., Johnston, M. K. \& Lücking, R. 2016. How diverse is the lichenized fungal family Trypetheliaceae (Ascomycota: Dothideomycetes)? A quantitative prediction of global species richness. The Lichenologist 48: 983-1011.

Archer, A. W. 1997. The lichen genus Pertusaria in Australia. Bibliotheca Lichenologica 69: 1-249. [Pertusaria impallescens, P. muricata, $P$. pertusella, $P$. subtruncata]

Archer, A. W. 2004. Pertusariaceae. In: McCarthy, P. M. \& Mallett, K. (eds), Flora of Australia, vol. 56A, Lichens 4, pp. 116-172. ABRS/ CSIRO Australia, Melbourne.

Archer, A. W. 2006. The lichen family Graphidaceae in Australia. Bibliotheca Lichenologica 94: 1-191. [Graphis turgidula]

Archer, A. W. 2009. Graphidaceae. In: McCarthy, P. M. (ed.), Flora of Australia, vol. 57, Lichens 5, pp. 84-194. ABRS and CSIRO Publishing, Canberra and Melbourne. [Graphis turgidula]

Archer, A. W. \& Elix, J. A. 2018. A preliminary world-wide key to the lichen genus Pertusaria (including Lepra species). http://rbgsyd.clients.squiz.net/science/Plant_Diversity_Research/Key_to_Pertusaria [Pertusaria impallescens]

Arup, U., Søchting, U. \& Frödén, P. 2013. A new taxonomy of the family Teloschistaceae. Nordic Journal of Botany 31: 16-83. [Gyalolechia bassiae]

Arvidsson, L. 1982. A monograph of the lichen genus Coccocarpia. Opera Botanica 67: 1-96. [Coccocarpia adnata, C. erythroxyli, C. palmicola, C. pellita, C. smaragdina, C. stellata $]$

Awasthi, D. D. 1965. Catalogue of lichens from India, Nepal, Pakistan, and Ceylon. Beihefte zur Nova Hedwigia 17: 1-137.

Baider, C., Florens, F. B. V., Baret, S., Beaver, K., Matatiken, D., Strasberg, D. \& Kueffer, C. 2010. Status of plant conservation in oceanic islands of the Western Indian Ocean. Proceedings of the 4th Global Botanic Gardens Congress, June 2010: 1-9.

Bailey, F. M. 1886. A Synopsis of the Queensland Flora, containing both Phanerogamous and Cryptogamous Plants. First Supplementum. Brisbane, pp. 70-78.

Bélanger, C. 1834. Lichens. In: Bélanger, M. C. \& Bory de Saint-Vincent, M. (eds), Voyage aux Indes-orientales, pendant les années 1825-1829. Botanique. II. partie. Cryptogamie, pp. 113-144. Paris. [Ca. 36 species reported from Mauritius. Note: The publication date is erroneously given as 1846 by some authors, including for some species in MycoBank; it should be 1834 (see Ross, Taxon 13: 193-196); 1846 might be the year of a re-edition.]

Bory de Saint-Vincent, J. B. G. M. 1804. Voyage dans les quatre principales îles des mers d'Afrique. Paris: F. Buisson. [Usnea sp.]

Bory de Saint-Vincent, J.-B. G. M. 1828. Roccelle. In: Audouin, J. V., Brongniart, A. T., de Candolle, A. P., Delafosse, G., Deshayes, G. P., Loiseleur-Deslongchamps, J. L. A., Drapiez, P. A. J., Dumas, J. B. A., Edwards, W. F., Edwards, H. M., Fée, A. L. A., Saint-Hilaire, G., Saint-Hilaire, I. G., Guérin-Méneville, F.-É., Guillemin, A., de Jussieu, A., Kunth, C. S., Latreille, P. A., Lesson, R.-P., Prevost, L. C., Richard, A. \& Bory de Saint-Vincent, J.-B. G. M. (eds), Dictionnaire Classique d'Histoire Naturelle, tome 14, pp. 650-651. Paris, Rey et Gavier. [Roccella boryi]

Brodo, I. M. 1991. Studies in the lichen genus Ochrolechia. 2. Corticolous species of North America. Canadian Journal of Botany 69: 733-772.

Büdel, B. 1987. Zur Biologie und Systematik der Flechtengattung Heppia und Peltula im sudlichen Afrika. Bibliotheca Lichenologica 23: 1-105. [Peltula rodriguesii]

Büdel, B. 1989. New localities for Peltula rodriguesii. The Lichenologist 21: 293. [Peltula rodriguesii] 
Castresana, J. 2000. Selection of conserved blocks from multiple alignments for their use in phylogenetic analysis. Molecular Biology and Evolution 17: 540-552.

Cheke, A. \& Hume, J. 2008. Lost land of the dodo. An ecological history of Mauritius, Réunion \& Rodrigues. T \& AD Poyser, London.

Coppins, B. J. \& Kondratyuk, S. Y. 1998. Opegrapha trassii sp. nov., a new lichenicolous fungus on Heterodermia. Folia Cryptogamica Estonica 32: 9-13. [Opegrapha trassii]

Coppins, B. J. \& Orange, A. 2009. Collemopsidium Nyl. In: Smith, C. W., Aptroot, A., Coppins, B. J., Fletcher, A., Gilbert, O. L., James, P. W. \& Wolseley, P. A. (eds), The Lichens of Great Britain and Ireland, pp. 357-361. British Lichen Society, London.

Coppins, B. J., James, P. W. \& Hawksworth, D. L. 1992. New species and combinations in the lichen flora of Great Britain and Ireland. The Lichenologist 24: 351-369.

Crittenden, P. D., David, J. C., Hawksworth, D. L. \& Campbell, F. S. 1995. Attempted isolation and success in the culturing of a broad spectrum of lichen-forming and lichenicolous fungi. New Phytologist 130: 267-297. [64 Mauritian specimens included]

Crombie, J. M. 1876a. New Lichens from the Island of Rodriguez. The Journal of Botany 14: 262-265. [Descriptions of 26 new species and one new variety]

Crombie, J. M. 1876b. Lichenes Insulae Rodriguesii. An enumeration of the lichens collected by Dr. J. B. Balfour during the VenusTransit Expedition 1874. Journal of the Linnean Society, Botany 15: 431-445. [Descriptions and reports from all lichens collected by Balfour in Rodrigues]

Crombie, J. M. 1879. Lichenes. Philosophical transactions of the Royal Society of London 168: 402-413. [Same text as Crombie 1876b, therefore no references to this paper are given in our checklist]

Darriba, D., Taboada, G. L., Doallo, R. \& Posada, D. 2012. jModelTest 2: more models, new heuristics and parallel computing. Nature Methods 9: 772 .

Daruty, A. 1873. Lichens de Maurice récoltés par M. A. Daruty et determinés par M. H. A. Weddell, D. M. P. de l'Institut. Transactions of the Royal Society of Arts and Sciences of Mauritius, n.s. 7: 163-166. [List of species without locality data; new species without descriptions (nomina nuda)]

David, J. C. \& Hawksworth, D. L. 1995. Lichens of Mauritius I: some new species and records. Bibliotheca Lichenologica 57: 93-111. [29 species; new: Cladonia mauritiana, Mycomicrothelia leuckertii, Ocellularia petrinensis, Pertusaria hymenelioides, P. muricata]

Degelius, G. 1974. The lichen genus Collema with special reference to the extra-European species. Symbolae Botanicae Upsalienses 20: 1-215. [Collema coilocarpum, C. leptaleum]

Delise, D. 1825 ('1822’). Histoire des lichens: Genre Sticta. Mémoires de la Société Linnéenne du Calvados 2: 1-167. [Several new taxa typified on Mauritius specimens]

Diederich, P., Lücking, R., Aptroot, A., Sipman, H. J. M., Braun, U., Ahti, T. \& Ertz, D. 2017. New species and new records of lichens and lichenicolous fungi from the Seychelles. Herzogia 30: 182-236.

Dodge, C. W. 1956. Some lichens of tropical Africa. II. Usnea. Annals of the Missouri Botanical Garden 43: 381-396. [Usnea eburnea]

Dodge, C. W. 1957. Some lichens of tropical Africa. II. Usnea (Continued). Annals of the Missouri Botanical Garden 44: 1-76. [Usnea distensa, U. fuscorubens, U. gracilis, U. luteola, U. nidifica, $U$. promontorii, U. pulvinata]

Dodge, C. W. 1959. Some lichens of tropical Africa. III. Parmeliaceae. Annals of the Missouri Botanical Garden 46: 39-193. [Parmelia appendiculata, P. decorata, P. hildenbrandtii, P. imerinensis, P. meiosperma, $P$. ornata, $P$. sieberi, $P$. subfuscescens, $P$. subhypoclysta, P. wightii, P. zeyheri]

Dodge, C. W. 1964. Some lichens of Tropical Africa. IV. Dermatocarpaceae to Pertusariaceae. Beihefte zur Nova Hedwigia 12: 1-282. [Anthracothecium borbonicum, Cyanisticta argyracea, C. aurigera, C. mougeotiana, Pertusaria pertusa var. minor, Sticta damicornis var. fucoides, S. glaberrima, Stictina flavireagens, S. macrophylla, S. macrophylla f. badia, S. nylanderiana, S. polita, S. strictula]

Dodge, C. W. 1971. Some lichens of tropical Africa. V. Lecanoraceae to Physciaceae. Beihefte zur Nova Hedwigia 38: 1-225. [Anaptychia cinerascens var. pulvinigera, Pyxine retirugella f. sorediigera, Lecanora coniopta]

Egea, J. M. \& Torrente, P. 1994. El género de hongos liquenizados Lecanactis (Ascomycotina). Bibliotheca Lichenologica 54: 1-205.

Elix, J. A. 2008. Lichen phytochemistry: additions and amendments I. Australasian Lichenology 63: 20-25. [Phyllopsora dolichospora]

Elix, J. A. 2014. A catalogue of standardized chromatographic data and biosynthetic relationships for lichen substances. Third Edition. Canberra: published by the author.

Elvebakk, A., Hong, S. G., Park, C. H., Robertsen, E. H. \& Jørgensen, P. M. 2016. Gibbosporina, a new genus for foliose and tripartite, Palaeotropic Pannariaceae species previously assigned to Psoroma. The Lichenologist 48: 13-52. [Gibbosporina didyma, G. mascarena]

Ertz, D. 2009. Revision of the corticolous Opegrapha species from the Paleotropics. Bibliotheca Lichenologica 102: 1-176. [Opegrapha difficilior, O. semiatra]

Ertz, D. \& Tehler, A. 2011. The phylogeny of Arthoniales (Pezizomycotina) inferred from nucLSU and RPB2 sequences. Fungal Diversity 49: 47-71.

Ertz, D., Lawrey, J. D., Common, R. S. \& Diederich, P. 2014. Molecular data resolve a new order of Arthoniomycetes sister to the primarily lichenized Arthoniales and composed of black yeasts, lichenicolous and rock-inhabiting species. Fungal Diversity 66: 113-137.

Ertz, D., Tehler, A., Irestedt, M., Frisch, A., Thor, G. \& van den Boom, P. 2015. A large-scale phylogenetic revision of Roccellaceae (Arthoniales) reveals eight new genera. Fungal Diversity 70: 31-53.

Ertz, D., Coppins, B. J. \& Sanderson, N. A. 2018a. The British endemic Enterographa sorediata is the widespread Syncesia myrticola (Roccellaceae, Arthoniales). The Lichenologist 50: 153-160.

Ertz, D., Sanderson, N., Łubek, A. \& Kukwa, M. 2018b. Two new species of Arthoniaceae from old-growth European forests, Arthonia thoriana and Inoderma sorediatum, and a new genus for Schismatomma niveum. The Lichenologist 50: 161-172.

Ertz, D., Sanderson, N., Coppins, B., Klepsland, J. T. \& Frisch, A. 2019. Opegrapha multipuncta and Schismatomma quercicola (Arthoniomycetes) belong to the Lecanoromycetes. The Lichenologist 51: 395-405.

Fée, A. L. A. 1824. Essai sur les cryptogames des écorces exotiques officinales. Paris. [Roccella boryi]

Flörke, H. G. 1809. Kleine Lichenenflora der Inseln Frankreich und Bourbon nach den Entdeckungen des Herrn Capitains Bory de St. Vincent. Magazin für die neuesten Entdeckungen in der gesammten Naturkunde, Gesellschaft Naturforschender Freunde zu Berlin 2: 122-128. [Lichen floridus, L. roccella, Pulmonaria dichotoma, $P$. gigantea]

Frisch, A. 2006. The lichen family Thelotremataceae in Africa. A revision with special consideration of the taxa from Cameroon and Tanzania. Bibliotheca Lichenologica 92: 3-370.

Frisch, A. \& Kalb, K. 2006. Contributions towards a new systematics of the lichen family Thelotremataceae II. A monograph of Thelotremataceae with a complex structure of the columella. Bibliotheca Lichenologica 92: 371-516. [Ocellularia mauritiana, Rhabdodiscus fissus]

Frisch, A., Thor, G., Ertz, D. \& Grube, M. 2014. The Arthonialean challenge: restructuring Arthoniaceae. Taxon 63: 727-744. [Dirina astridae, D. monothalamia]

Frisch, A., Ohmura, Y., Ertz, D. \& Thor, G. 2015. Inoderma and related genera in Arthoniaceae with elevated white pruinose pycnidia or sporodochia. The Lichenologist 47: 233-256. [Glomerulophoron mauritiae]

Galloway, D. J. 1988. Studies in Pseudocyphellaria (lichens). I. The New Zealand species. Bulletin of the British Museum (Natural History), Botany Series 17: 1-267. [Pseudocyphellaria crocata] 
Galloway, D. J. 1994. Studies in Pseudocyphellaria (lichens) IV. Palaeotropical species (excluding Australia). Bulletin of the British Museum (Natural History), Botany Series 24: 115-159. [Crocodia aurata, Pseudocyphellaria argyracea, P. crocata, P. desfontainii, P. gilva, P. intricata (fig. 19)]

Galloway, D. J., 1995. Studies on the lichen genus Sticta (Schreber) Ach.: III. Notes on species described by Bory de St-Vincent, William Hooker, and Delise, between 1804 and 1825. Nova Hedwigia 61: 147-188. [Pulmonaria gigantea, Sticta dichotoma, S. dichotoma var. pendula, S. macrophylla, S. plumbea]

Galloway, D. J. 2001. Sticta. In: McCarthy, P. M. (ed.), Flora of Australia, Vol. 58A, pp. 78-97. ABRS and CRISO Publishing, Canberra and Melbourne. [Sticta variabilis]

Galloway, D. J. \& James, P. W. 1986. Species of Pseudocyphellaria Vainio (Lichenes), recorded in Delise's 'Histoire des Lichens: Genre Sticta'. Nova Hedwigia 42: 423-490. [Sticta aspera, S. aurigera var. nuda, S. mougeotiana, S. mougeotiana var. xantholoma]

Galloway, D. J. \& Jørgensen, P. M. 1987. Studies in the lichen family Pannariaceae II. The genus Leioderma Nyl. The Lichenologist 19: 345-400. [Leioderma erythrocarpum]

Galloway, D. J., Kantvilas, G. \& Elix, J. A. 2001. Pseudocyphellaria. In: McCarthy, P. M. (ed.), Flora of Australia, volume 58A, Lichens 3, pp. 47-77. ABRS/CSIRO Australia, Melbourne.

Gardes, M. \& Bruns, T. D. 1993. ITS primers with enhanced specificity for basidiomycetes, application to the identification of mycorrhizae and rusts. Molecular Ecology 2: 113-118.

Grube, M. \& Ryan, B. D. 2002. Collemopsidium. In: Nash, T. H., III, Ryan, B. D., Gries, C. \& Bungartz, F. (eds), Lichen Flora of the Greater Sonoran Desert Region. I, pp. 162-164. Lichens Unlimited, Arizona State University, Tempe, Arizona.

Gueidan, C., Aptroot, A., Cáceres, M. E. S. \& Binh, N. Q. 2016. Molecular phylogeny of the tropical lichen family Pyrenulaceae: contribution from dried herbarium specimens and FTA card samples. Mycological Progress 15: 1-21.

Guzow-Krzemińska, B., Flakus, A., Kosecka, M., Jabłońska, A., Rodriguez-Flakus, P. \& Kukwa, M. 2019. New species and records of lichens from Bolivia. Phytotaxa 397: 257-279.

Gyelnik,V. 1931a. Lichenes extraeuropaei novi criticique. Repertorium specierum novarum regni vegetabilis 29: 1-10. [Stictina flavireagens]

Gyelnik, V. 1931b. Additamenta ad cognitionem Parmeliarum. II. Repertorium specierum novarum regni vegetabilis 29: 273-291. [Parmelia mauritiana]

Hafellner, J. 1981. Monographie der Flechtengattung Letrouitia (Lecanorales, Teloschistineae). Nova Hedwigia 35: 645-729. [Letrouitia vulpina]

Hafellner, J. 1997. A world monograph of Brigantiaea (lichenized Ascomycotina, Lecanorales). Symbolae Botanicae Upsalienses 32: 35-74. [Brigantiaea leucoxantha]

Hale, M. E. Jr. 1962. A new species of Parmelia from Asia: P. subcorallina. The Journal of Japanese botany 37: 345-347. [Parmelia subcorallina]

Hale, M. E. Jr. 1965. A monograph of Parmelia subgenus Amphigymnia. Contributions from the United States National Herbarium 36: 193358. [Parmelia cristifera, P. saccatiloba, P. sieberi, P. zollingeri]

Hale, M. E. 1968. A synopsis of the lichen genus Pseudevernia. The Bryologist 71: 1-11. [Pseudevernia mauritiana]

Hale, M. E. Jr. 1971. Morden-Smithsonian Expedition to Dominica: the lichens (Parmeliaceae). Smithsonian Contributions to Botany 4: 1-25. [Parmelia microblasta]

Hale, M. E. Jr. 1976. A monograph of the lichen genus Bulbothrix Hale (Parmeliaceae). Smithsonian Contributions to Botany 32: 1-29. [Bulbothrix suffixa]

Hale, M. E. 1990. A synopsis of the lichen genus Xanthoparmelia (Vainio) Hale (Ascomycotina, Parmeliaceae). Smithsonian Contributions to Botany 74: 1-250. [Xanthoparmelia phaeophana]
Harada, H. 1999. Pyrenocollema japonicum, a new freshwater species of pyrenocarpous lichen from Japan. The Bryologist 102: 50-52.

Harris, R. C. 1990. Some Florida Lichens. Publ. by the Author, Bronx, NY.

Harris, R. C. 1995. More Florida lichens. Including the 10\% tour of the Pyrenolichens. Publ. by the Author, Bronx, NY.

Holm, A. C. \& Gregersen, R. 2002. Stictaceae (Lecanorales, lichenized Ascomycota) of Mauritius and La Réunion in the Indian Ocean. In: Adsersen, H. E. \& Søchting, U. (eds), Study tour to the Mascarenes 2001, pp. 78-98. Unpublished report, Botanical Institute, University of Copenhagen. [Crocodia, Lobaria, Pseudocyphellaria and Sticta spp.]

Holm, A. C., Gregersen, R., Søchting, U. \& Timdal, E. 2002. Lobariaceae of Mauritius and La Réunion in the Indian Ocean. IMC7 Book of Abstracts, Oslo.

Hue, A. M. 1892. Lichenes exotici a professore W. Nylander descripti vel recogniti et in herbario musei Parisiensis pro maxima parte asservati in ordine systematico dispositi sunt. Paris. [Coenogonium leprieurii, Crocynia gossypina, Lecanora murorum, Lecidea vulpina, Ricasolia sublaevis, Stictina strictula, Usnea longissima, U. trichodea]

Hue, A. M. 1898. Lichenes extra-europaei a pluribus collectoribus ad Museum Parisiensi missi. Nouvelles archives du Muséum d'Histoire Naturelle, sér. 3, 10: 213-280. [Stereocaulon salazinum]

Hue, A. 1924. Monographia Crocyniarum. Bulletin de la Société Botanique de France 71: 311-402. [Crocynia mauritiana]

Huelsenbeck, J. P. \& Ronquist, F. 2001. MRBAYES: Bayesian inference of phylogeny. Bioinformatics 17: 754-755.

Johansson, S., Søchting, U., Elix, J. A. \& Wardlaw, J. H. 2005. Chemical variation in the lichen genus Letrouitia (Ascomycota, Letrouitiaceae). Mycological Progress 4: 139-148. [Letrouitia vulpina]

Johnston, H. H. 1894. Report on the Flora of Round Island, Mauritius. Transactions and proceedings of the Botanical Society of Edinburgh 20: 263-264. [Dirinaria picta, Lecanora subfusca, Ramalina calicaris, Xanthoparmelia conspersa]

Jørgensen, P. M. 2000 ['2001']. Survey of the lichen family Pannariaceae on the American continent, north of Mexico. The Bryologist 103: 670-704.

Jørgensen, P. M. 2003. Conspectus familiae Pannariaceae (Ascomycetes lichenosae). Ilicifolia 4: 1-78.

Jørgensen, P. M. 2004. Further contributions to the Pannariaceae (1ichenized Ascomycetes) of the Southern Hemisphere. Bibliotheca Lichenologica 88: 229-253. [Pannaria cinerascens, P. multifida, P. pruinosa]

Joshi, S., Upreti, D. K., Divakar, P. K., Lumbsch, H.,T. \& Lücking, R. 2018. A re-evaluation of thelotremoid Graphidaceae (lichenized Ascomycota: Ostropales) in India. The Lichenologist 50: 627-678.

Kalb, K., Hafellner, J. \& Staiger, B. 1995. Haematomma-Studien. II. Lichenicole Pilze auf Arten der Flechtengattung Haematomma. Bibliotheca Lichenologica 59: 199-222. [Cornutispora lichenicola]

Kalb, K., Buaruang, K., Mongkolsuk, P. \& Boonpragob, K. 2012. New or otherwise interesting lichens. VI, including a lichenicolous fungus. Phytotaxa 42: 35-47.

Kashiwadani, H. \& Moon, K. H. 2007. The genus Ramalina (Ascomycota, Ramalinaceae) in Indonesia. Bibliotheca Lichenologica 96: 145-156. [Ramalina nervulosa]

Katoh, K., Misawa, K., Kuma, K. \& Miyata, T. 2002. MAFFT: a novel method for rapid multiple sequence alignment based on fast Fourier transform. Nucleic Acids Research 30: 3059-3066.

Katoh, K., Rozewicki, J. \& Yamada, K. D. 2017. MAFFT online service: multiple sequence alignment, interactive sequence choice and visualization. Briefings in Bioinformatics 2017: 1-7.

Katoh, K. \& Toh, H. 2008. Improved accuracy of multiple ncRNA alignment by incorporating structural information into a MAFFT-based framework. BMC Bioinformatics 9: 212.

Kistenich, S., Timdal, E., Bendiksby, M. \& Ekman, S. 2018. Molecular systematics and character evolution in the lichen family 
Ramalinaceae (Ascomycota: Lecanorales). Taxon 67: 871-904. [Krogia coralloides, Phyllopsora mauritiana, Physcidia wrightii, Rolfidium coccocarpoides]

Kistenich, S., Bendiksby, M., Ekman, S., Cáceres, M. E. S., Hernández M., J. E. \& Timdal, E. 2019a. Towards an integrative taxonomy of Phyllopsora (Ramalinaceae). The Lichenologist 51: 323-392.

Kistenich, S., Bendiksby, M., Vairappan, C. S., Weerakoon, G., Wijesundara, S., Wolseley, P. A. \& Timdal, E. 2019b. A regional study of the genus Phyllopsora (Ramalinaceae) in Asia and Melanesia. MycoKeys 53: 23-72.

Kondratyuk, S. Y., Lokös, L., Zarei-Darki. B., Haji Moniri, M., Tchabanenko, S., Galanina, I., Yakovchenko, L., Hooshmand, F., Ezhkin, A. \& Hur, J. 2013. Five new Caloplaca species (Teloschistaceae, Ascomycota) from Asia. Acta Botanica Hungarica 55: 41-60.

Kraichak, E., Parnmen, S., Lücking, R. \& Lumbsch, H. T. 2013. Gintarasia and Xalocoa, two new genera to accommodate temperate to subtropical species in the predominantly tropical Graphidaceae (Ostropales, Ascomycota). Australian Systematic Botany 26: 466-474.

Kraichak, E., Parnmen, S., Lücking, R., Rivas Plata, E., Aptroot, A., Cáceres, M. E. S., Ertz, D., Mangold, A., Mercado-Diaz, J. A., Papong, K., van den Broeck, D., Weerakoon, G. \& Lumbsch, H. T. 2014. Revisiting the phylogeny of Ocellularieae, the second largest tribe within Graphidaceae (lichenized Ascomycota: Ostropales). Phytotaxa 189: 52-81.

Krog, H. 1994. Typification and interpretation of Ramalina arabum. Acta Botanica Fennica 150: 99-104. [Ramalina arabum]

Krog, H. \& Swinscow, T. D. V. 1976. The genus Ramalina in East Africa. Norwegian Journal of Botany 23: 153-175. [Ramalina subfraxinea var. leiodea]

Krog, H. \& Swinscow, T. D. V. 1981. Parmelia subgenus Amphigymnia (lichens) in East Africa. Bulletin of the British Museum (Natural History), Botany Series 9: 143-231. [Parmelia cristifera]

Lamb, I. M. 1966. Die Gattung Stereocaulon. Lichenes, Stereocaulaceae (Flechten des Himalaya 3). Khumbu Himal 1: 349-352. [Leprocaulon arbuscula]

Lamb, I. M. \& Ward, A. 1974. A preliminary conspectus of the species attributed to the imperfect lichen genus Leprocaulon Nyl. Journal of the Hattori Botanical Laboratory 38: 499-553. [Leprocaulon arbuscula]

Laundon, J. R. 1981. The species of Chrysothrix. The Lichenologist 13: 101-121. [Chrysothrix candelaris]

Laundon, J. R. 2008. Some synonyms in Chrysothrix and Lepraria. The Lichenologist 40: 411-414. [Chrysothrix candelaris]

Laurer, F. 1827. Sieber'sche Lichenen. Linnaea 2: 38-46. [New: Peltidea floerkeana, Sticta damicornis var. polita, S. damicornis var. fucoides, S. glaberrima, S. pulmonacea; several other records]

Lindau, G. 1908. Lichenes von Madagaskar, Mauritius und den Comoren. Mit Beschreibung neuer Arten von Dr. A. Zahlbruckner. In: Voeltzkow, A. (ed.), Reise in Ostafrika in den Jahren 1903-1905, 3, pp. 1-14, 1 pl. Schweizerbart'sche Verlags Buchhandlung, Stuttgart. [24 taxa from Mauritius]

Liu, Y., Whelen, S. \& Hall, B. 1999. Phylogenetic relationships among Ascomycetes: evidence from an RNA polymerase II subunit. Molecular Biology and Evolution 16: 1799-1808.

Lücking, R. 2014. A key to species of the Ocellularia papillata, perforata and terebrata morphodemes (Ascomycota: Graphidaceae). Glalia 6: 1-34.

Lücking, R. 2015. Thelotremoid Graphidaceae from the NYBG herbarium: New species, range extensions, and a forgotten lichen. Opuscula Philolichenum 14: 1-57.

Lücking, R. \& Pérez-Ortega, S. 2015. Four new species of Ocellularia (lichenized Ascomycota: Graphidaceae) from Cuba, with a revised taxonomy of the $O$. bahiana complex and a key to thelotremoid taxa with small, brown, (sub-)muriform ascospores. The Lichenologist 47: 305-322.

Lücking, R. \& Timdal, E. 2016. New species of Dictyonema and Cyphellostereum (lichenized Basidiomycota: Hygrophoraceae) from tropical Africa and the Indian Ocean, dedicated to the late Hildur Krog. Willdenowia 46: 191-199. [Cyphellostereum bicolor, Dictyonema album, D. coppinsii and other species]

Lücking, R., Cáceres, M. E. S., Silva, N. G. \& Alves, R. J. V. 2015a. The genus Cora in the South Atlantic and the Mascarenes: Two novel taxa and inferred biogeographic relationships. The Bryologist 118: 293-303. [Cora gyrolophia]

Lücking, R., Mangold, A., Rivas Plata, E., Parnmen, S., Kraichak, E. \& Lumbsch, H. T. 2015b. Morphology-based phylogenetic binning to assess a taxonomic challenge: a case study in Graphidaceae (Ascomycota) requires a new generic name for the widespread Leptotrema wightii. Botanical Journal of the Linnean Society 179: 436-443.

Lücking, R., Nelsen, M. P., Aptroot, A., Benatti, M. N., Binh, N. Q., Gueidan, C., Gutiérrez, M. C., Jungbluth, P., Lumbsch, H. T., Marcelli, M. P., Moncada, B., Naksuwankul, K., Orozco, T., Salazar-Allen, N. \& Upreti, D. K. 2016. A pot-pourri of new species of Trypetheliaceae resulting from molecular phylogenetic studies. The Lichenologist 48: 639-660.

Lücking, R., Moncada, B., McCune, B., Farkas, E., Goffinet, B., Parker, D., Chaves, J. L., Lőkös, L., Nelson, P. R., Spribille, T., Stenroos, S., Wheeler, T., Yanez-Ayabaca, A., Dillman, K., Gockman, O. T., Goward, T., Hollinger, J., Tripp, E. A., Villella, J., Álvaro-Alba, W. R., Arango, C. J., Cáceres, M. E. S., Coca, L. F., Printzen, C., Rodríguez, C., Scharnagl, K., Rozzi, R., Soto-Medina, E. \& Yakovchenko, L. S. 2017a. Pseudocyphellaria crocata (Ascomycota: Lobariaceae) in the Americas is revealed to be thirteen species, and none of them is P. crocata. The Bryologist 120:441-500. [Pseudocyphellaria crocata, P. desfontainii, P. neglecta]

Lücking, R., Dal Forno, M., Moncada, B., Coca, L. F., Vargas-Mendoza, L. Y., Aptroot, A., Arias, L. J., Besal, B., Bungartz, F., Cabrera-Amaya, D. M., Cáceres, M. E. S., Chaves, J. L., Eliasaro, S., Gutiérrez, M. C., Marin, J. E. H., Herrera-Campos, M. A., Holgado-Rojas, M. E., Jonitz, H., Kukwa, M., Lucheta, F., Madriñán, S., Marcelli, M. P., Martins, S. M. A., Mercado-Díaz, J. A., Molina, J. A., Morales, E. A., Nelson, P. R., Nugra, F., Ortega, F., Paredes, T., Patiño, A. L., Peláez-Pulido, R. N., Pérez, R. E. P., Perlmutter, G. B., Rivas-Plata, E., Robayo, J., Rodríguez, C., Simijaca, D. F., Soto-Medina, E., Spielmann, A. A., Suárez-Corredor, A., Torres, J.-M., Vargas, C. A., Yánez-Ayabaca, A., Weerakoon, G., Wilk, K., Pacheco, M. C., Diazgranados, M., Brokamp, G., Borsch, T., Gillevet, P. M., Sikaroodi, M. \& Lawrey, J. D. 2017. Turbo-taxonomy to assemble a megadiverse lichen genus: seventy new species of Cora (Basidiomycota: Agaricales: Hygrophoraceae), honouring David Leslie Hawksworth's seventieth birthday. Fungal Diversity 84: 139-207.

Lumbsch, H. T. 1994. Die Lecanora subfusca-Gruppe in Australasien. Journal of the Hattori Botanical Laboratory 77: 1-175. [Lecanora conizopta]

Lumbsch, H. T., Feige, G. B. \& Elix, J. A. 1995. A revision of the usnic acid containing taxa belonging to Lecanora sensu stricto (Lecanorales: lichenized Ascomycotina). The Bryologist 98: 561-577. [Lecanora achroa]

Maddison, W. P. \& Maddison, D. R. 2015. Mesquite: a modular system for evolutionary analysis. Version 3.04. Available from: http:// mesquiteproject.org.

Masson, D., Benatti, M. N. \& Sérusiaux, E. 2015. The description of a new species reveals underestimated diversity in the lichen genus Bulbothrix (Parmeliaceae) in Africa. The Lichenologist 47: 323-334. [Bulbothrix aff. johannis]

Mathey, A. 1974 ('1971'). Contribution à l'étude du genre Siphula (lichens) en Afrique. Nova Hedwigia 22: 795-878. [Siphula mascarena]

McCarthy, P. M. 2001. Trichotheliaceae. In: McCarthy, PM (ed.), Flora of Australia, vol. 58A, Lichens 3, pp. 105-157. ABRS/CSIRO Australia, Melbourne.

McCarthy, P. M. 2003. Catalogue of the lichen family Porinaceae. Bibliotheca Lichenologica 87: 1-164. [Porina innata] 
McCarthy, P. M. \& Kantvilas, G. 1999. Pyrenocollema montanum, a new species from Tasmania. The Lichenologist 31: 227-230.

Millanes, A. M., Diederich, P., Ekman, S. \& Wedin, M. 2011. Phylogeny and character evolution in the jelly fungi (Tremellomycetes, Basidiomycota, Fungi). Molecular Phylogenetics and Evolution 61: 12-28.

Millanes, A. M., Truong, C., Westberg, M., Diederich, P. \& Wedin, M. 2014. Host switching promotes diversity in host-specialized mycoparasitic fungi: uncoupled evolution in the Biatoropsis-Usnea system. Evolution 68: 1576-1593.

Millanes, A. M., Diederich, P., Westberg, M. \& Wedin, M. 2016. Three new species in the Biatoropsis usnearum complex. Herzogia 29: 337-354.

Miller, M. A., Pfeiffer, W. \& Schwartz, T. 2010. Creating the CIPRES Science Gateway for inference of large phylogenetic trees. In: Proceedings of the Gateway Computing Environments Workshop (GCE), 14 November, 2010, New Orleans, pp. 1-8.

Mohr, F., Ekman, S. \& Heegaard, E. 2004. Evolution and taxonomy of the marine Collemopsidium species (lichenized Ascomycota) in north-west Europe. Mycological Research 108: 515-532.

Moncada, B., Reidy, B. \& Lücking, R. 2014. A phylogenetic revision of Hawaiian Pseudocyphellaria sensu lato (lichenized Ascomycota: Lobariaceae) reveals eight new species and a high degree of inferred endemism. The Bryologist 117: 119-160. [Crocodia aurata, Pseudocyphellaria crocata]

Moncada, B., Mercado-Díaz, J. A. \& Lücking, R. 2018. The identity of Sticta damicornis (Ascomycota: Lobariaceae): a presumably widespread taxon is a Carribean endemic. The Lichenologist 50: 591-597.

Motyka, J. 1936. Lichenum generis Usnea studium monographicum. Pars systematica, vol. 1, pp. i-iv, 1-304. Leopoli. [Usnea baileyi]

Motyka, J. 1938. Lichenum generis Usnea studium monographicum. Pars systematica, vol. 2, pp. 304-651. Leopoli. [Usnea contorta, $U$. fuscorubens, $U$. straminea]

Müller, J. 1882. Lichenologische Beiträge. XV. Flora 65: 397-402.

Müller, J. 1891a. Lichenes Brisbanenses a cl. F. M. Bailey, Government Botanist, prope Brisbane (Queensland) in Australia orientali lecti. Nuovo Giornale Botanico Italiano 23: 385-404.

Müller, J. 1891b. Lichenes Bellendenici a cl. M. F. Bailey, Gouvernment Botanist, ad Bellenden Kerr Australiae orientalis lecti et sub numeris citatis missi. Hedwigia 30: 47-56.

Müller, J. 1892. Lichenes exotici. Hedwigia 31: 276-288. [Thalloidima ayresianum]

Müller, J. 1895. Thelotremeae et Graphideae novae quas praesertim ex hb. Reg. Kewensi exponit. The Journal of the Linnean Society, Botany 30: 451-463. [Graphis gomphospora, G. turgidula, Opegrapha angulosa, Phaeographis medusuliza

Myers, N., Mittermeier, R. A., Mittermeier, C. G., da Fonseca, G. A. B \& Kent, J. 2000. Biodiversity hotspots for conservation priorities. Nature 403: 853-858.

Nelsen, M. P., Lücking, R., Andrew, C. J., Aptroot, A., Cáceres, M. E. S., Mercado-Díaz, J. A., Rivas Plata, E. \& Lumbsch, H. T. 2014. Molecular phylogeny reveals the true colours of Myeloconidaceae (Ascomycota: Ostropales). Australian Systematic Botany 27: 38-47.

Nylander, W. 1858 ('1857’). Énumération générale des lichens, avec l'indication sommaire de leur distribution géographique. Mémoires de la Société Impériale des Sciences Naturelles de Cherbourg 5: 85-146. [Lecidea leucoxantha var. ochrocarpa, L. mauritiana]

Nylander, W. 1859. Lichenes exotici, lichenes in regionibus exoticis quibusdam vigentes exponit synopticis enumerationibus. Annales des Sciences Naturelles 11: 205-264. [Byssocaulon molliusculum, Lecidea mauritiana, L. megacarpa, Placodium murorum, Ricasolia crenulata var. stenospora, Roccella tinctoria, Sticta variabilis, Psoroma sphinctrinum]

Nylander, W. 1870. Recognitio monographica Ramalinarum. Bulletin de la Société Linnéenne de Normandie 4: 101-181. [Ramalina canaliculata, $R$. subcalicaris, $R$. subfraxinea]
Nylander, W. 1874 ('1873'). Lichenes insularum Andaman. Bulletin de la Société Linnéenne de Normandie 7: 162-182. [Chiodecton confusum, Graphis aequabilis]

Ohmura, Y. 2001. Taxonomic study of the genus Usnea (lichenized Ascomycetes) in Japan and Taiwan. Journal of Hattori Botanical Laboratory 90: 1-96.

Ohmura, Y. 2012. A synopsis of the lichen genus Usnea (Parmeliaceae, Ascomycota) in Taiwan. Memoirs of the National Museum of Nature and Science 48: 91-137.

Orange, A. 2015. A new freshwater Porina (Porinaceae, Ostropales) from Great Britain. The Lichenologist 47: 351-358.

Orange, A., James, P. W. \& White, F. J. 2001. Microchemical methods for the identification of lichens. British Lichen Society, London.

Øvstedal, D. O. \& Gremmen, N. J. M. 2010. Additional lichen records from Subantarctica 2. New taxa and combinations from Îles Kerguelen, Prince Edward Islands and Heard Island. Australasian Lichenology 67: 29-33.

Papong, K. \& Lumbsch, H. T. 2011. A taxonomic survey of Lecanora sensu stricto in Thailand (Lecanoraceae; Ascomycota). The Lichenologist 43: 299-320. [Lecanora achroa]

Parnell, J. A. N., Cronk, Q., Jackson, P. W. \& Strahm, W. 1989. A study of the ecological history, vegetation and conservation management of Ile aux Aigrettes, Mauritius. Journal of Tropical Ecology 5: 355-374. [9 species reported]

Parnmen, S., Lücking, R. \& Lumbsch, H. T. 2012. Phylogenetic classification at generic level in the absence of distinct phylogenetic patterns of phenotypical variation: a case study in Graphidaceae (Ascomycota). PLoS ONE 7(12): e51392.

Parnmen, S., Cáceres, M. E. S., Lücking, R. \& Lumbsch, H. T. 2013. Myriochapsa and Nitidochapsa, two new genera in Graphidaceae (Ascomycota: Ostropales) for chroodiscoid species in the Ocellularia clade. The Bryologist 116: 127-133.

Rambaut, A. \& Drummond, A. J. 2007. Tracer v1.6. Available from http://beast.bio.ed.ac.uk/

Rambaut, A. 2012. FigTree v1.4.2. Available from: http://tree.bio.ed.ac. uk/software/figtree/

Riedl, H. \& Riedl-Dorn, C. 1986. Ergebnisse einer Sammel- und Studienreise nach Mauritius im Sommer 1981. Linzer biologische Beiträge 18: 381-387. [Lecanora muralis]

Rivas Plata, E., Lücking, R., Sipman, H. J. M., Mangold, A., Kalb, K. \& Lumbsch, H. T. 2010. A world-wide key to the thelotremoid Graphidaceae, excluding the Ocellularia-Myriotrema-Stegobolus clade. The Lichenologist 42: 139-185.

Rivas Plata, E., Lücking, R. \& Lumbsch, H. T. 2012. A new classification for the family Graphidaceae (Ascomycota: Lecanoromycetes: Ostropales). Fungal Diversity 52: 107-121.

Rivas Plata, E., Parnmen, S., Staiger, B., Mangold, A., Frisch, A., Weerakoon, G., Hernández, J. E., Cáceres, M. E. S., Kalb, K., Sipman, H. J. M., Common, R. S., Nelsen, M. P., Lücking, R. \& Lumbsch, H. T. 2013. A molecular phylogeny of Graphidaceae (Ascomycota, Lecanoromycetes, Ostropales) including 428 species. Mycokeys 6: 55-94.

Ronquist, F. \& Huelsenbeck, J. P. 2003. MrBayes 3: Bayesian phylogenetic inference under mixed models. Bioinformatics 19: 1572-1574.

Ruoss, E. \& Ahti, T. 1989. Systematics of some reindeer lichens (Cladonia subg. Cladina) in the Southern Hemisphere. The Lichenologist 21: 29-44. [Cladonia confusa]

Santesson, R 1952. Foliicolous lichens I. A revision of the taxonomy of the obligately foliicolous, lichenized fungi. Symbolae Botanicae Upsalienses 12: 1-590. [Gyalectidium filicinum, Porina epiphylla, Strigula smaragdula, S. smaragdula var. stellata]

Seaward, M. R. D. \& Aptroot, A. 2000. The lichen flora of the Chagos Archipelago, including a comparison with other island and coastal tropical floras. Tropical Bryology 18: 185-198. 
Seaward, M. R. D. \& Aptroot, A. 2006. A preliminary checklist of lichens for the Seychelles group. Journal of the Hattori Botanical Laboratory 100: 765-781.

Sérusiaux, E., Fischer, E. \& Killmann, D. 2006. Nyungwea, a new genus of lichen with goniocyst-producing stipes from Rwanda and Uganda (East Africa). The Lichenologist 38: 115-121.

Silvestro, D. \& Michalak, I. 2012. RaxmlGUI: a graphical front-end for RAxML. Organisms Diversity and Evolution 12: 335-337.

Simon, A. 2015. Les photomorphes au sein des Lobariaceae (Peltigerales, Ascomycota): étude de leur dynamique évolutive via trois approches génétiques. Université de Liège, Faculté des Sciences, Département de Biologie, Ecologie, Evolution. (not published). [Sticta dichotoma, S. macrophylla, S. mascarena, S. pseudodiversa, S. variabilis]

Simon, A., Goffinet, B., Magain, N. \& Sérusiaux, E. 2018. High diversity, high insular endemism and recent origin in the lichen genus Sticta (lichenized Ascomycota, Peltigerales) in Madagascar and the Mascarenes. Molecular Phylogenetics and Evolution 122: 15-28. [Sticta dichotoma, S. macrophylla, S. variabilis]

Sipman, H. J. M. 1983. A monograph of the lichen family Megalosporaceae. Bibliotheca Lichenologica 18: 1-241. [Megalospora atrorubicans, $M$. coccodes]

Sipman, H. J. M. 2010. Thelotrema hnatiukii, a new lichen species and other interesting Thelotremataceae from Aldabra, Indian Ocean. Lichenologist 42: 187-189.

Sipman, H. J. M., Lücking, R., Aptroot, A., Kalb, K., Chaves, J. L. \& Umana, L. 2012. A first assessment of the Ticolichen biodiversity inventory in Costa Rica and adjacent areas: the thelotremoid Graphidaceae (Ascomycota: Ostropales). Phytotaxa 55: 1-214.

Staiger, B. \& Kalb, K. 1995. Haematomma-Studien. I. Die Flechtengattung Haematomma. Bibliotheca Lichenologica 59: 1-198. [Haematomma africanum, $H$. collatum, $H$. persoonii]

Stamatakis, A. 2014. RAxML version 8: a tool for phylogenetic analysis and post-analysis of large phylogenies. Bioinformatics 30: 1312-1313.

Stenroos, S., Högnabba, F., Myllys, L., Hyvönen, J. \& Thell, A. 2006. High sensitivity in symbiotic associations of lichenized ascomycetes and cyanobacteria. Cladistics 22: 230-238. [Pseudocyphellaria crocata]

Stevens, G. N. 1986. Three new saxicolous Ramalinae from Australia. The Lichenologist 18: 183-189. [Ramalina litorea]

Stevens, G. N. 1987. The lichen genus Ramalina in Australia. Bulletin of the British Museum (Natural History), Botany Series 16: 107-223. [Ramalina litorea

Stevens, G. N. 1991. The tropical Pacific species of Usnea and Ramalina and their relationship to species in other parts of the world. In Galloway, D. J., Tropical lichens: their systematics, conservation, and Ecology. Systematics Association Special Volume 43: 47-67. [Usnea trichodeoides]

Stevens, G. N. 1999. A Revision of the lichen family Usneaceae in Australia. Bibliotheca Lichenologica 72: 1-128.

Stevens, G. N. 1990. Usnea himantodes Stirton and its synonyms. The Lichenologist 22: 409-412.

Sutjaritturakan, J. \& Kalb, K. 2015. Ocellularia (Ascomycota: Ostropales ) - three new species, a new record and a key for all species so far recorded for Thailand. Herzogia 28: 545-555.

Swinscow, T. D. V. \& Krog, H. 1975. The genus Pyxine in East Africa. Norwegian Journal of Botany 22: 43-68.

Swinscow, T. D. V. \& Krog, H. 1981. The genus Phyllopsora, with a report on the East African species. The Lichenologist 13: 203-247. [Phyllopsora mauritiana]

Swinscow, T. D. V. \& Krog, H. 1988. Macrolichens of East Africa. British Museum (Natural History), London. [Lecidea coccocarpioides, Sticta dichotoma]

Taylor, T. 1847. New Lichens, principally from the Herbarium of Sir William J. Hooker. The London journal of botany 6: 148-197.
[Lecanora vigilans, Lecidea mauritiana, Megalospora coccodes, Parmelia cristifera, $P$. saccatiloba]

Tehler, A. \& Irestedt, M. 2007. Parallel evolution of lichen growth forms in the family Roccellaceae (Arthoniales, Ascomycota). Cladistics 23: 432-454. [Dirina paradoxa subsp. africana, Roccella montagnei f. teretior, R. flaccida]

Tehler, A., Irestedt, M., Wedin, M. \& Ertz, D. 2010. The Old World Roccella species outside Europe and Macaronesia: taxonomy, evolution and phylogeny. Systematics and Biodiversity 8: 223-246. [Roccella boryi]

Tehler, A., Ertz, D. \& Irestedt, M. 2013. The genus Dirina (Roccellaceae, Arthoniales) revisited. The Lichenologist 45: 427-476. [Dirina astridae]

Thébaud, C., Warren, B. H., Cheke, A. C. \& Strasberg, D. 2009. Mascarene Islands, Biology. In: Gillespie, R. G. \& Clague, D. (eds), Encyclopedia of Islands, pp. 612-619. Univ. of California Press, Berkeley, U. S. A.

Timdal, E. 1991. A monograph of the genus Toninia (Lecideaceae, Ascomycetes). Opera Botanica 110: 1-137. [Toninia ayresiana]

Timdal, E. 2002. Krogia coralloides, a new lichen genus and species from Mauritius. The Lichenologist 34: 293-296. [Krogia coralloides]

Timdal, E. \& Krog, H. 2001. Further studies on African species of the lichen genus Phyllopsora (Lecanorales). Mycotaxon 77: 57-89. [11 Phyllopsora species from Mauritius]

Vainio, E. 1887. Monographia Cladoniarum Universalis, 1. Acta Societatis pro Fauna et Flora Fennica 4: 1-509. [Cladonia medusina, C. pycnoclada, C. rangiferina, C. squamosa]

Vainio, E. 1894. Monographia Cladoniarum Universalis, 2. Acta Societatis pro Fauna et Flora Fennica 10: 1-499. [Cladonia borbonica, C. fimbriata, C. pityrea var. subareolata]

Van den Boom, P. P. G., Brand, M., Ertz, D., Kalb, K., Magain, N., Masson, D., Schiefelbein, U., Sipman, H. J. M. \& Sérusiaux, E. 2011. Discovering the lichen diversity of a remote tropical island: working list of species collected on Reunion (Mascarene archipelago, Indian Ocean). Herzogia 24: 325-349.

Vilgalys, R. \& Hester, M. 1990. Rapid genetic identification and mapping of enzymatically amplified ribosomal DNA from several Cryptococcus species. Journal of Bacteriology 172: 4238-4246.

Virah-Sawmy, M., Mauremootoo, J., Marie, D., Motala, S. \& Sevathian, J.-C. 2009. Rapid degradation of a Mauritian rainforest following the first 60 years of plant invasion. Oryx 43: 1-9.

Wetmore, C. M. 2004. The isidiate corticolous Caloplaca species in North and Central America. The Bryologist 107: 284-292. [Gyalolechia bassiae]

Wirth, M. \& Hale, M. E. Jr. 1978. Morden-Smithsonian Expedition to Dominica: the lichens (Graphidaceae). Smithsonian Contributions to Botany 40: 1-64. [Graphis turgidula]

Wolseley, P. A. \& Hawksworth, D. L. 2009. Schismatomma Flot. \& Körb. ex A. Massal. In: Smith, C. W., Aptroot, A., Coppins, B. J., Fletcher, A., Gilbert, O. L., James, P. W. \& Wolseley, P. A. (eds), The Lichens of Great Britain and Ireland, pp. 834-837. British Lichen Society, London.

Zahlbruckner, A. 1927. Additamenta ad Lichenographiam Japoniae. Botanical Magazine [Tokyo] 41: 314-364.

Zhurbenko, M. 2009. Sagediopsis pertusariicola (Verrucariales), a new lichenicolous ascomycete from the Arctic. Nova Hedwigia 88: 549-555.

Zhurbenko, M. P. \& Pino-Bodas, R. 2017. A revision of lichenicolous fungi growing on Cladonia, mainly from the Northern Hemisphere, with a worldwide key to the known species. Opuscula Philolichenum 16: 188-266.

Zoller, S., Scheidegger, C. \& Sperisen, C. 1999. PCR primers for the amplification of mitochondrial small subunit ribosomal DNA of lichen-forming ascomycetes. The Lichenologist 31: 511-516. 